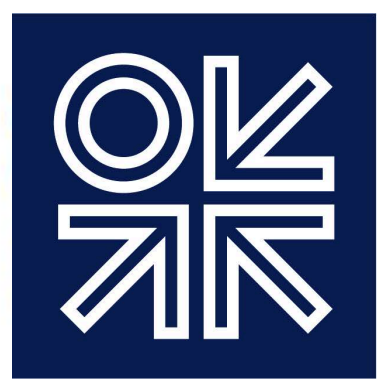

THE OXFORD

INSTITUTE

FOR ENERGY

STUDIES

June 2015

\title{
The Outlook for Azerbaijani Gas Supplies to Europe:
}

Challenges and Perspectives

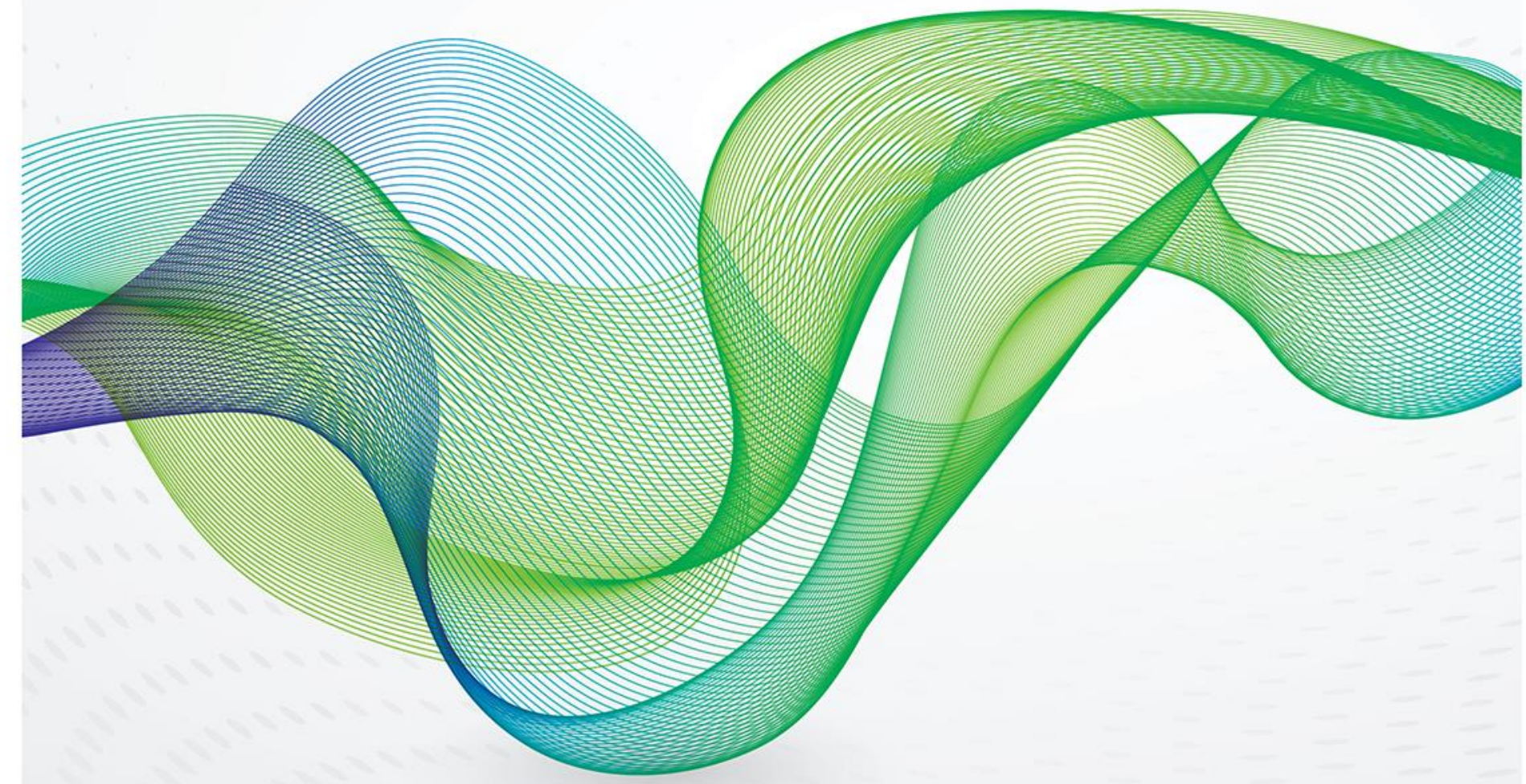



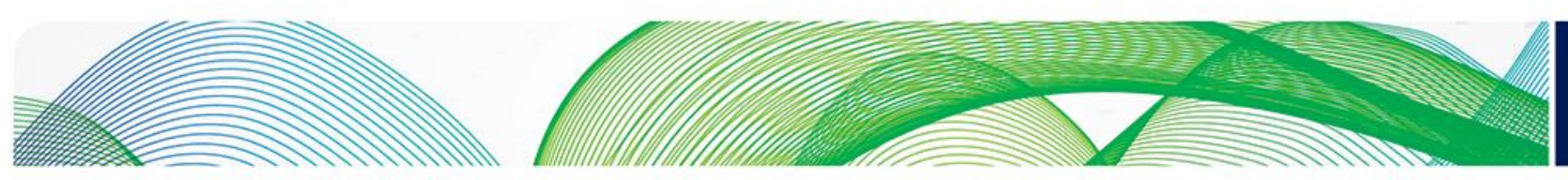

$\frac{\mathrm{or}}{\mathrm{W}}$

The contents of this paper are the authors' sole responsibility. They do not necessarily represent the views of the Oxford Institute for Energy Studies or any of its members.

Copyright $\odot 2015$

Oxford Institute for Energy Studies

(Registered Charity, No. 286084)

This publication may be reproduced in part for educational or non-profit purposes without special permission from the copyright holder, provided acknowledgment of the source is made. No use of this publication may be made for resale or for any other commercial purpose whatsoever without prior permission in writing from the Oxford Institute for Energy Studies.

ISBN 978-1-78467-028-3 

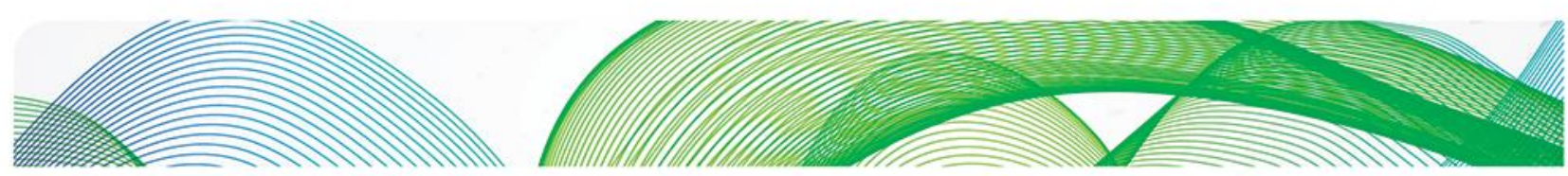
O는

\section{Contents}

Preface

Acknowledgements

v

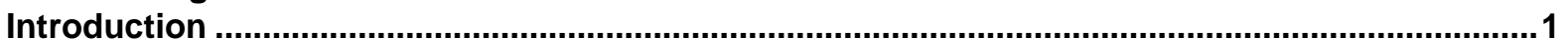

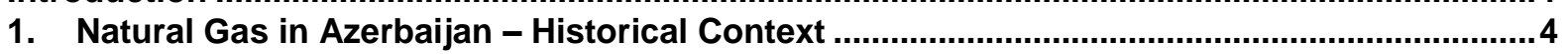

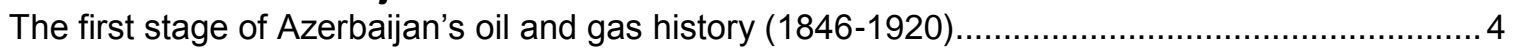

The second stage of Azerbaijan's oil and gas history (1920-1949) .......................................... 5

The third stage of Azerbaijan's oil and gas history (1950-1969) …........................................... 6

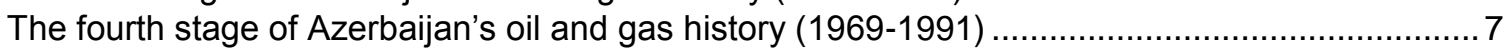

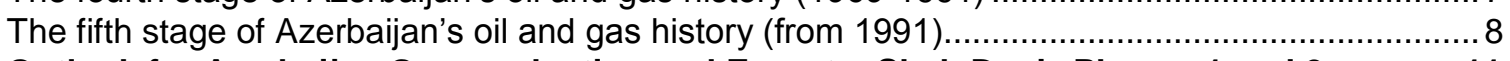

2. Outlook for Azerbaijan Gas production and Exports: Shah Deniz Phases 1 and $2 \ldots \ldots \ldots \ldots . . . .11$

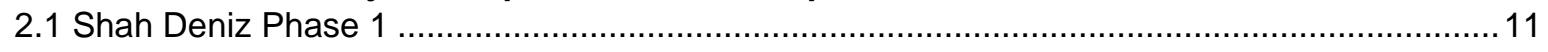

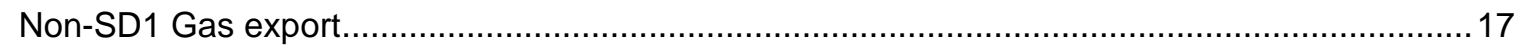

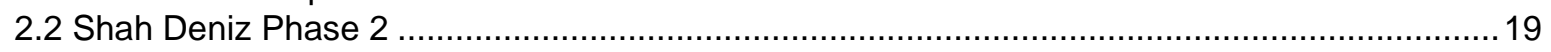

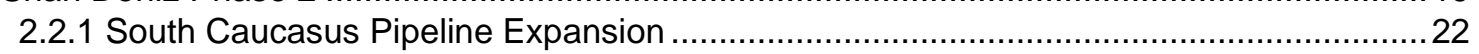

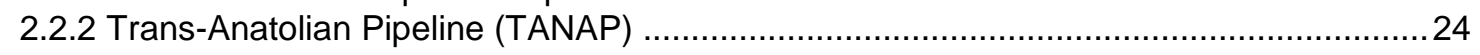

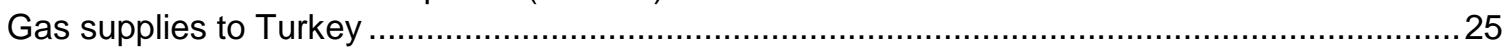

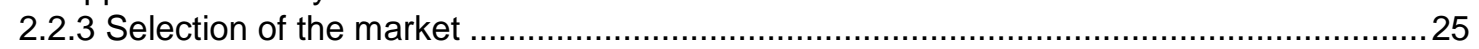

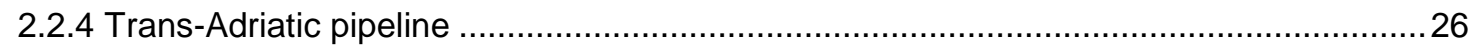

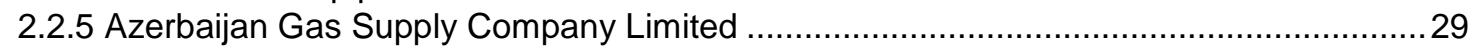

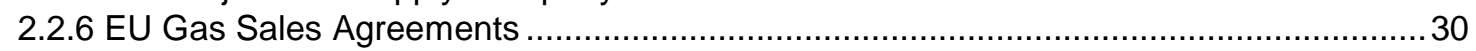

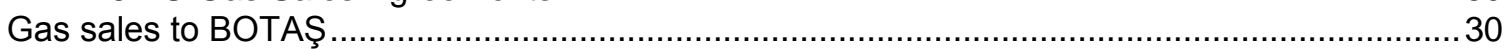

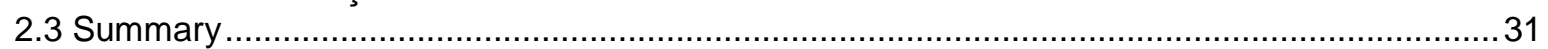

3. SOCAR gas production portfolio: ACG Associated Gas and Shallow Water Guneshli, Gum

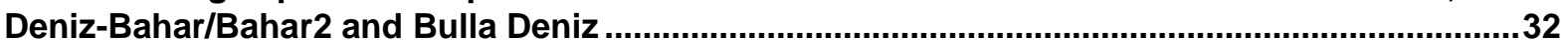

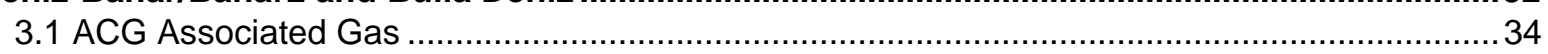

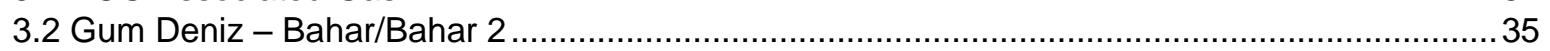

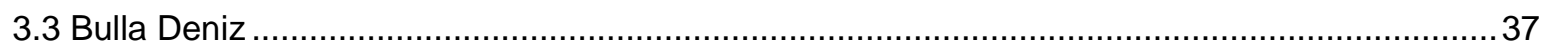

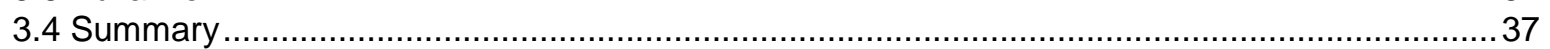

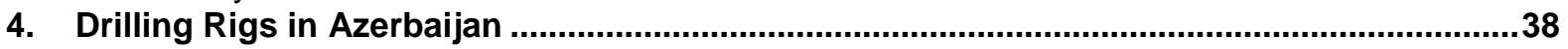

5. Commercial Natural Gas Reserves and Partially Appraised Discoveries: Absheron, ACG

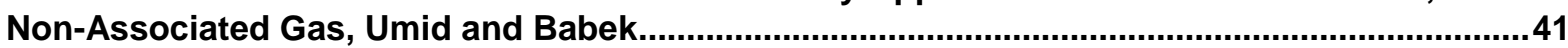

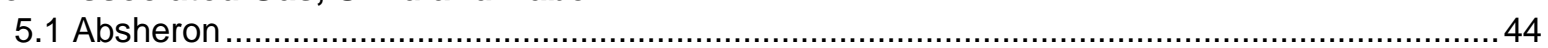

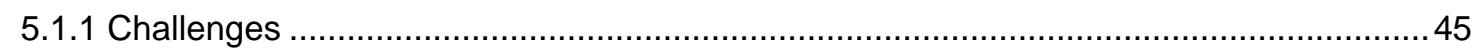

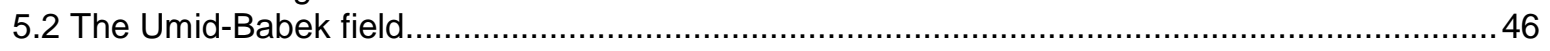

5.3 Azeri-Chirag-Guneshli non-associated natural gas (ACG-NAG) …........................................ 48

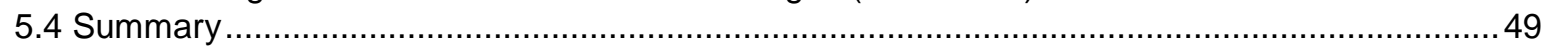

6. Exploration Prospects: SD3, Nakhchivan, Shafag-Asiman, Zafar-Mashal, Garabagh, Inam,

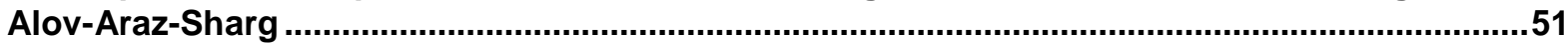

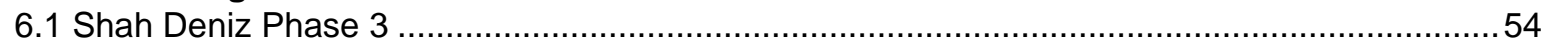

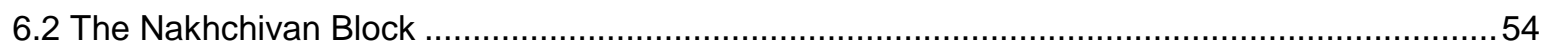

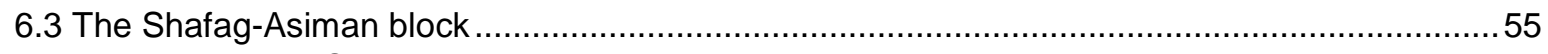

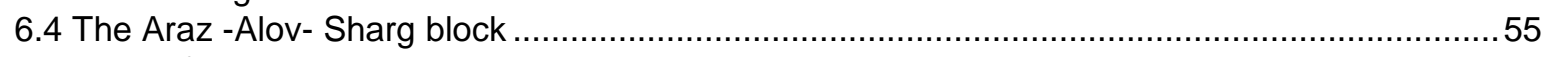

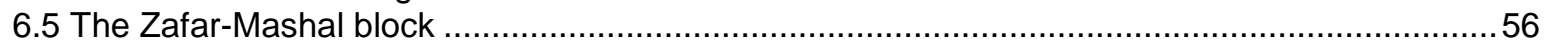

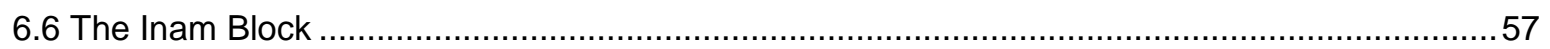

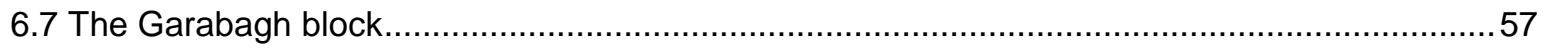

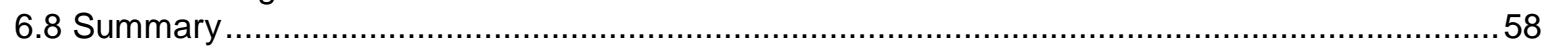

7. Possible Marketing Arrangements for and Transportation of Un-contracted gas ...............60

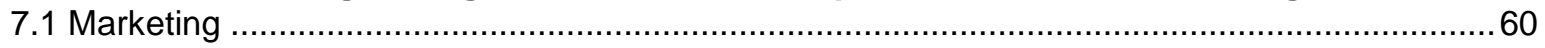

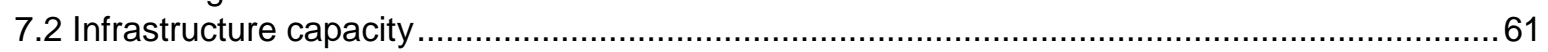

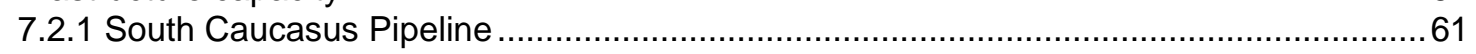



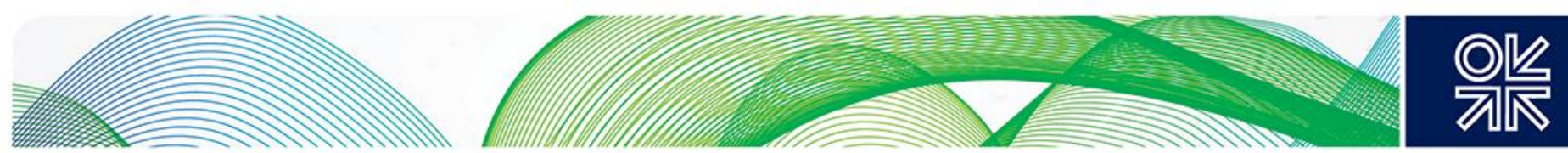

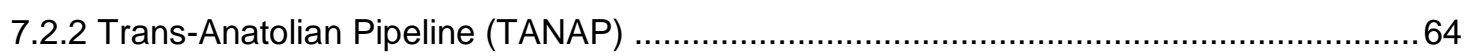

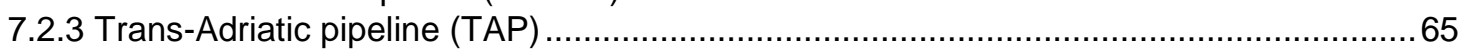

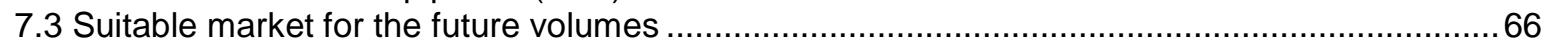

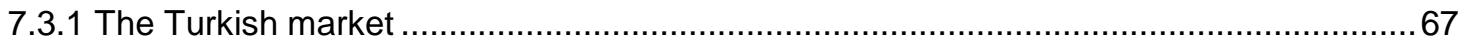

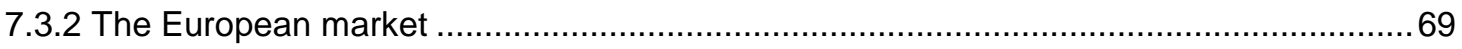

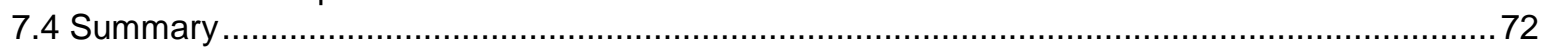

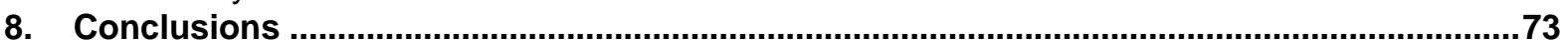

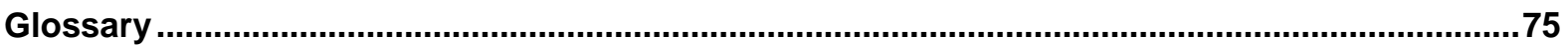

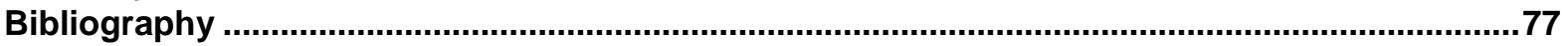

Figures

Figure 1: Oil production in Azerbaijan 1870 - 1920 (Million tonnes) ..................................................

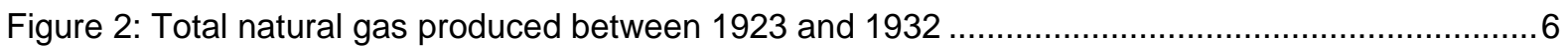

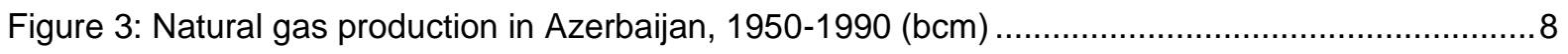

Figure 4: Shah Deniz Production Sharing Agreement: Shareholders and stakes (\%) .......................13

Figure 5: Azerbaijan natural gas production and consumption 2003-2013 (bcm/a) .........................14

Figure 6: The natural gas volumes contracted under Shah Deniz Phase $1(\mathrm{bcm} / \mathrm{a})$...........................14

Figure 7: The natural gas exports (delivered volumes) from SD1, 2007-2013 ….............................16

Figure 8: Gas contracted for export from Azerbaijan, 2010-2030 (excludes SD2 exports) ..................18

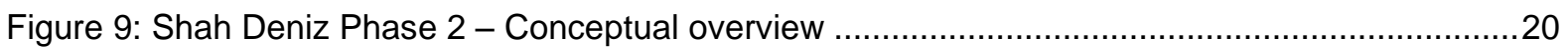

Figure 10: Shah Deniz Phase 2 gas production volumes, 2018-2036 (bcm/a) ..................................20

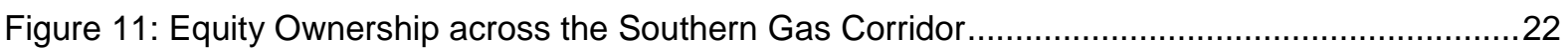

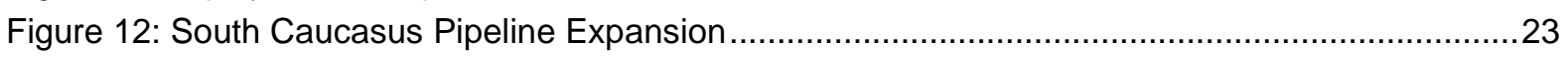

Figure 13: European gas hubs price correlation: 2007-2014

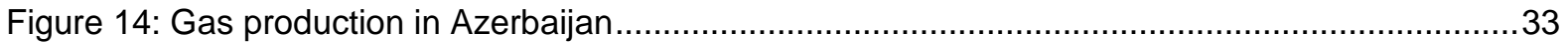

Figure 15: Natural gas production from key fields, (million cubic metres/day) ......................................34

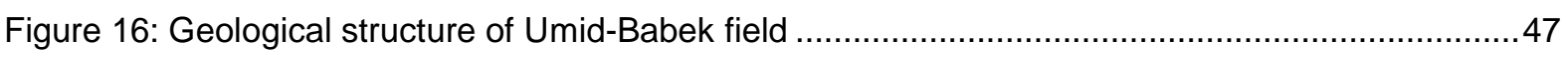

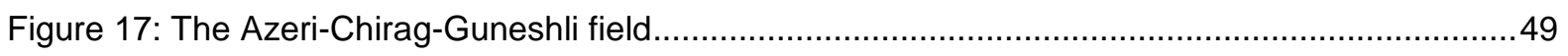

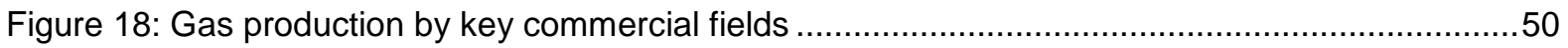

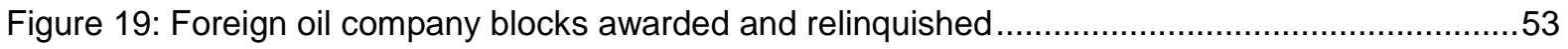

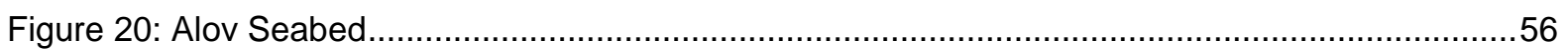

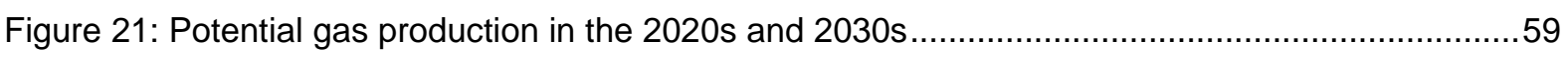

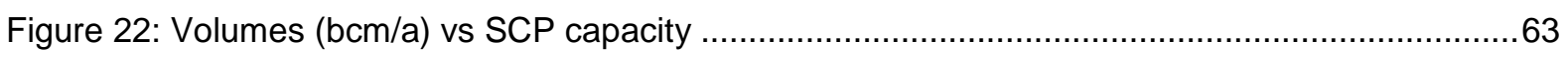

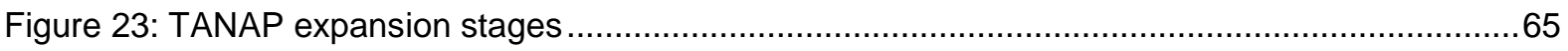

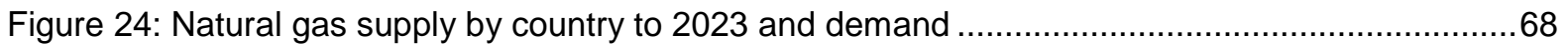

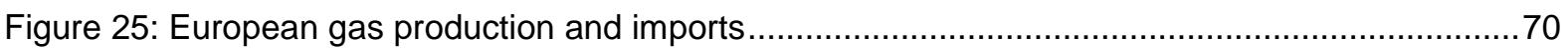

Figure 26: European gas supply-demand balance, bcm ...........................................................

\section{Tables}

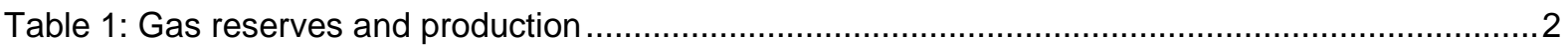

Table 2: Azerbaijan and USSR/CIS gas production 1940-2005 (bcm) ..........................................

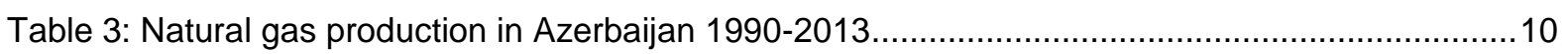

Table 4: Azerbaijan gas production balance 2006 - $2013(\mathrm{bcm})$......................................................11

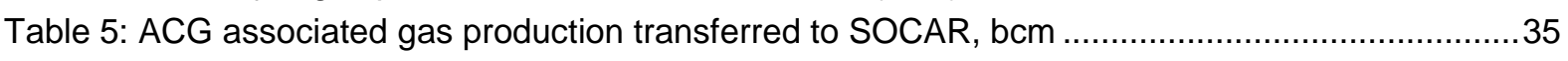



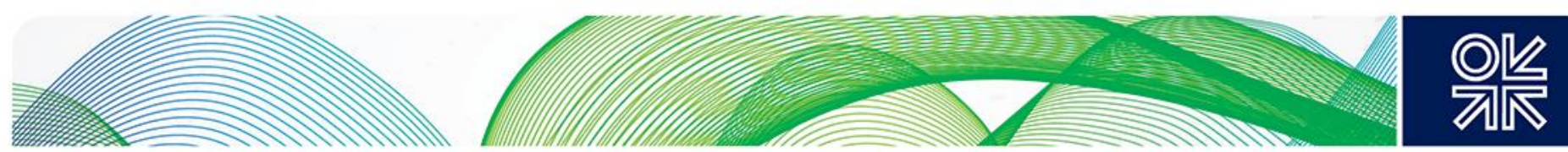

Table 6: Azerbaijani Reserves Classification 42

Table 7: Estimated reserves by discovery and development status .........................................44

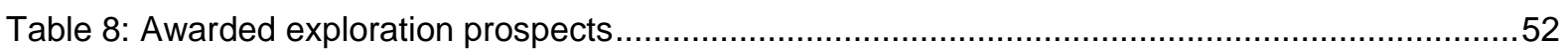

Table 9: Exploration blocks relinquished and participating companies ...........................................5

Table 10: The total capacity allocated at each entry and exit point in TAP is presently as follows:.....66

\section{Maps}

Map 1: Location of the Shah Deniz field 12

Map 2: Nakhchivan Autonomous Republic ........................................................................ 19

Map 3: Trans Adriatic Pipeline and the Ionian Adriatic Pipeline (IAP) ......................................26

Map 4: Interconnectors between Italy and adjacent markets .................................................28

Map 5: IAP and its position within the region of South East Europe ..........................................29

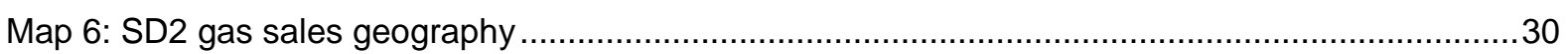

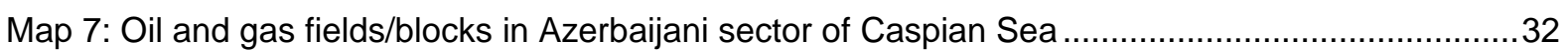

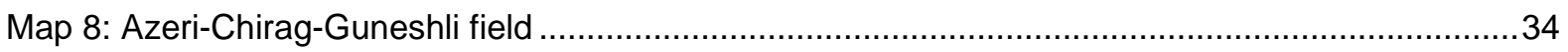

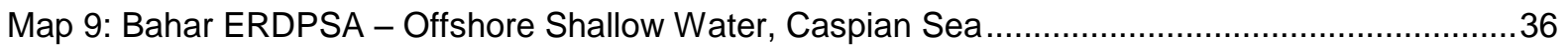

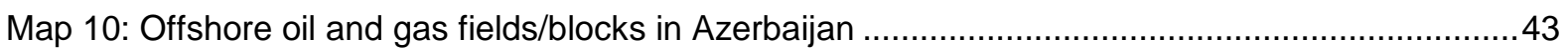

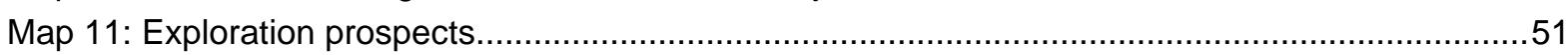

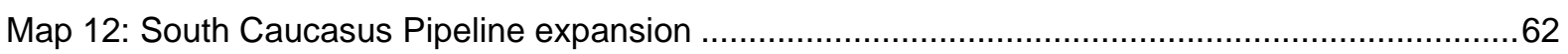

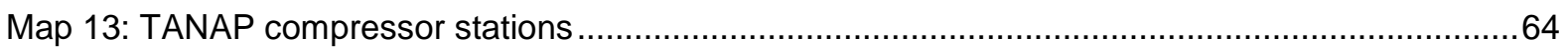



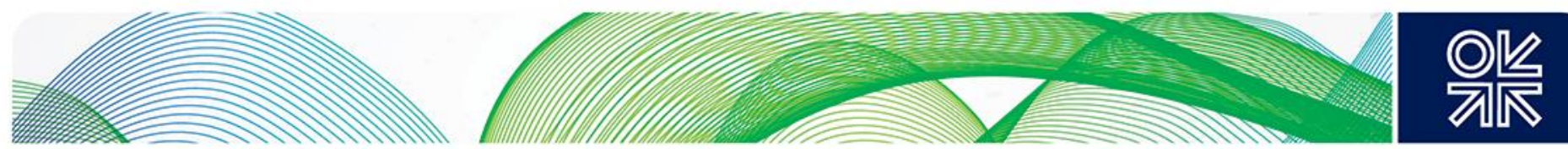

\section{Preface}

As the birthplace of the oil and gas industry, Azerbaijan's long and rich history is intertwined with hydrocarbon production, with oil drilling pre-dating activity in Pennsylvania by 13 years. The involvement of foreign oil companies in the late 1800s, including the Nobel Brothers, resulted in the country becoming the world's foremost oil producer at the turn of that century. The Soviet era precluded further international investment, and saw the initial collapse but then a sustained growth in oil production and a dramatic growth in gas production commencing in the 1920s. Azerbaijan became a highly gasified economy with gas trade flows with Iran and Russia. The 1990s witnessed the return of the IOCs with the Azeri-Chirag-Guneshli field (oil and associated gas) and the Shah Deniz (gas and condensate) field developments reversing the trend of production decline and creating an export surplus in both oil and gas.

In this paper, Gulmira Rzayeva provides a comprehensive analysis of the challenges which were surmounted in the development of the Shah Deniz field, not least of which related to establishing export pipelines and marketing arrangements in Turkey, and (for Phase 2) Europe. In large part this was due to the exemplary level of co-operation achieved between the Government of Azerbaijan, SOCAR, its state oil and gas company, and the various consortia of IOCs.

Turning to the future, the paper details the nature and estimated potential of partially developed fields, discoveries at varying stages of appraisal and prospective structures in the Azerbaijan sector of the Caspian Sea. Apart from the inevitable range of uncertainty over future production levels and timing, what emerges are the twin challenges of drilling rig availability (it being impossible to bring an assembled rig into the Caspian due to width restrictions on the Volga-Don canal) and the highly challenging sub-surface drilling conditions.

The modest prospects for domestic gas demand growth and Azerbaijan's geographic location require that any future gas field development decision will also require a degree of certainty on export infrastructure capacity to the primary target markets of Turkey and South and South East Europe. These issues are covered in detail.

A primary objective of the OIES Natural Gas Programme is to produce research which provides deep insight on areas of importance in the world of gas, from researchers with specialized knowledge on those topics. This paper provides the reader with a comprehensive insight into the main drivers and the future dynamics of this important future gas supply source for the wider European region.

Howard Rogers

Oxford 


\section{Acknowledgements}

My greatest thanks are due to my colleagues Howard Rogers and Simon Pirani in Oxford, who kindly read the text, edited and reviewed it. I am very grateful to Akif Narimanov, Denis Lemarchal, Ricardo Bravo, Bernard Geiss, Heike Liebold and Martin Wellens who also helped me in various ways.

My thanks to John Elkins who edited the text, to David Sansom for the maps, and to Kate Teasdale who took care of publication. The opinions expressed, and the mistakes made, are mine alone. 

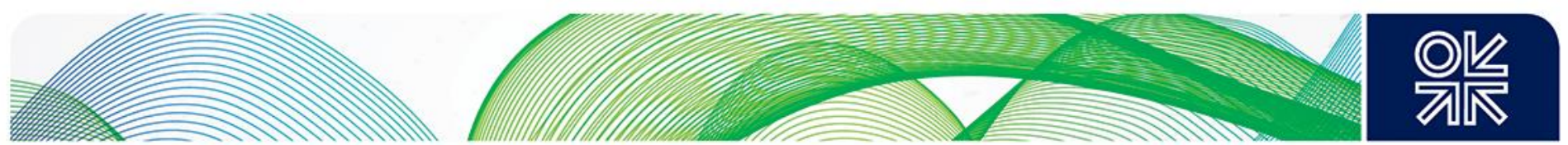

\section{Introduction}

Azerbaijan's gas sector and gas production is dominated by one giant field, Shah Deniz, which is currently producing around $9 \mathrm{bcm} / \mathrm{a}$ at its plateau level. The next phase of development of the field will increase the plateau by some $17 \mathrm{bcm} / \mathrm{a}$, to a total of more than $26 \mathrm{bcm} / \mathrm{a}$ from both phases from late 2018.

This major gas upstream project required new export infrastructure. The South Caucasus Pipeline (SCP), currently has up to $8 \mathrm{bcm} / \mathrm{a}$ capacity, and transports gas from Azerbaijan through Georgia to Turkey. This pipeline will be expanded to $26 \mathrm{bcm} / \mathrm{a}$ to accommodate natural gas from the next phase of Shah Deniz and from future fields in Azerbaijan that are under different stages of development.

The natural gas sector has rapidly expanded since independence through inward investment by several large oil and gas companies. BP along with SOCAR is the main operating company and has a significant share in the main producing field, Shah Deniz, and related transportation infrastructure.

The national oil company, SOCAR ${ }^{1}$, has stakes in the entire value chain from the well head to the market - Shah Deniz, SCP, TANAP ${ }^{2}$, TAP $^{3}$ as well as many other offshore fields and structures in Azerbaijan. It operates some fields on its own, including the Guneshli (Shallow Water) field, and other smaller onshore and offshore fields. Other onshore fields are operated by foreign investors jointly with SOCAR, which retains a minority interest.

Azerbaijan does not routinely conduct competitive open licensing rounds for exploration and development opportunities offered to foreign investors. All contracts have been concluded through direct negotiations with the national oil company, SOCAR. Licence awards were at a peak in 1997, when seven blocks were awarded (six PSAs and one Joint Venture). Since 1997, the number of awards has diminished.

Azerbaijan's onshore has been producing hydrocarbons from the mid-19th century and many fields have passed their peak production phase. Exploration is now focused on the offshore sector where large prospects are located. There are a number of promising fields and prospective structures in the Azerbaijani sector of the Caspian Sea, such as Absheron, Umid/Babek, ACG Deep layer gas etc. that can add significant amounts of gas for export in the future.

Although during the period of 2000-2010 there were disappointing results from drilling in offshore blocks, due to difficult technical conditions and consequent high costs, there is significant gas resource potential in the Azerbaijani sector of the Caspian Sea. Azerbaijan's future natural gas supply growth will derive from two Groups of reserves and resources and, when developed, will show a growing surplus of un-contracted free gas potentially available for new exports. In this paper, Group 1 refers to gas fields, (Commercial reserves) that are in production, and also discoveries which are the

\footnotetext{
${ }^{1}$ The State Oil Company of Azerbaijan Republic, SOCAR, was created on 12 September 1992, to manage oil and gas production, refining, exports and imports on behalf of the state. It is Azerbaijan's largest and most important company in terms of tax revenue, employment and international presence. The company has become a "national champion" with stakes in the Azeri-Chirag-Guneshli and Shah Deniz projects, the main export pipelines and with an expanding overseas presence (including gas marketing). In addition to its roles as producer, refiner, pipeline operator and contract negotiator, SOCAR also holds a direct working interest in all the PSCs signed in the Azerbaijani sector to date.

2 The Trans Anatolian Pipeline

${ }^{3}$ The Trans Adriatic Pipeline
} 

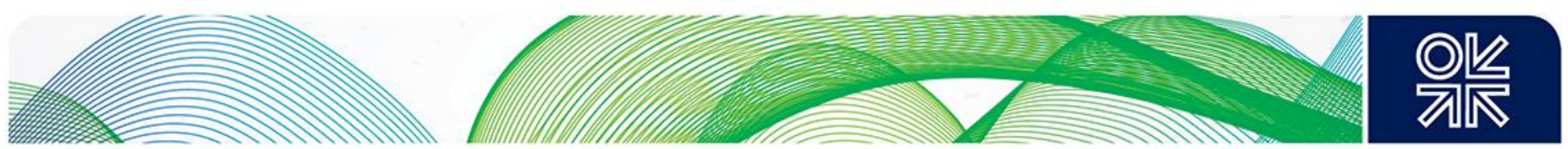

subject of further appraisal which we consider to be contenders for development in the near to medium term (i.e. within 15 years), (Probable Developments). Group 2 refers to Resources (prospective structures, and so called technical reserves), which are either prospects which have not yet been the subject of (sufficient) exploration drilling or those accumulations which have not been demonstrated to be commercially viable at the present time.

The country has the capability to provide additional gas export volumes beyond Shah Deniz phase 1 and 2 developments from 2021-22 onwards, when the Absheron field will come on-stream. Significant surplus and uncommitted gas volumes will require more export transport capacity than the SCP can provide. For that the SCP expansion and construction of a new expandable infrastructure - TANAP is envisaged.

The main target markets for un-contracted gas coming from the so called next generation gas fields and prospective structures are the Turkish and European markets. The European natural gas market has undergone changes as a result of external factors; these are commercial and economic, but also political. The political crisis in Ukraine may in future affect the gas market as a result of measures the European Commission may take to decrease gas imports from Russia. It is obvious that the desired outcome of these measures will be gradual and Russian imports will still be needed at some level for at least the next decade. However, potential gas from non-Russian sources, to reduce reliance on Russian imports, is of utmost importance for the European market, especially for those countries where long term gas supplies contracts (LTSCs) with Gazprom are expiring.

At the moment, the only country that has secured all the needed binding agreements to deliver significant volumes $(10.9 \mathrm{bcm} / \mathrm{a})$ of new non-Russian gas supply to the Greek, Italian and the Bulgarian markets is Azerbaijan and the Shah Deniz consortium. This gas has been sold to European customers for 25 years (with a total contractual value of $\$ 100$ billion $^{4}$ ). The most significant effect will be felt from the $1 \mathrm{bcm} / \mathrm{a}$ that will be delivered to the Bulgarian market, where dependence on Gazprom supplies is the highest. Some of the future as yet un-contracted "free" gas may be exported to the European and the Turkish markets, thus offering further diversification in the SEE and Central European markets.

As shown in the Table 1, according to SOCAR, Azerbaijan's proved gas reserves are estimated at 2.5 trillion cubic metres (tcm). Current domestic gas consumption is around $10 \mathrm{bcm} / \mathrm{a}$ and it is unlikely that the demand will grow significantly in the coming years - as $96 \%$ of the country has been gasified and no rapid natural gas consuming industrial growth is expected.

Table 1: Gas reserves and production

Source: SOCAR ${ }^{5}$

\begin{tabular}{|l|c|}
\hline Gas Reserves (proved, 2013), trillion cm & 2.5 \\
\hline Gas production (2013), bcm & 29.4 \\
\hline Gas Reserves/Production (R/P) & $50+$ years \\
\hline
\end{tabular}

Consequently, the lion's share of the free gas will be available for export. The European market, along with the Turkish market, could be seen as a priority for gas sourced in Azerbaijan, depending on the cost of production and transportation, supply/demand dynamics and the price.

\footnotetext{
4 "BP-Led Group Inks Azeri Gas Deals Worth $\$ 100$ Billion”, Wall Street Journal, http://www.wsj.com/articles/SB10001424127887323808204579085110787214276, 19 September 2013

${ }^{5}$ In the BP Statistical Review (2013) Azerbaijan reserves are stated as $0.9 \mathrm{tcm}$, and the r/p ratio as 54.3 years. This is because SOCAR includes many resources described in this paper that with BP methodology are not classified as reserves.
} 

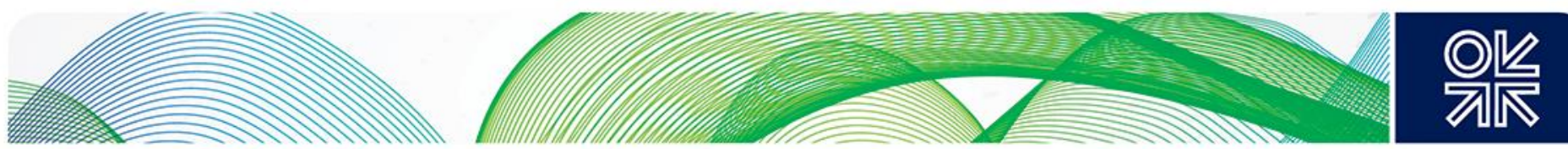

This paper aims at providing an overview of the natural gas production prospects in the 2020s and 2030s. Research has been conducted by analysing possible challenges, such as financial (high cost of production and transportation), technical (availability of drilling rigs), geological (complex geological structure, high reservoir pressure etc.) and marketing (unpredictable European and Turkish markets). These factors affect the timing and extent of production.

Section 1 sheds light on the historical background of the oil and gas industry in Azerbaijan. Section 2 describes the outlook for Azerbaijan gas production and exports from Shah Deniz Phase 1 and 2 as well as its transportation and market. SOCAR's own gas production portfolio from ACG Associated Gas and Shallow Water Guneshli, Gum Deniz-Bahar/Bahar2, and Bulla Deniz is described in Section 3. Drilling rig availability in Azerbaijan, a major issue for future gas production, is described in Section 4. Section 5 analyses potential further natural gas reserves and resources: Absheron, Umid/Babek and ACG Non-Associated Gas, their probable size and timing of production. Section 6 attempts to describe the exploration prospects (Nakhchivan, Shafag-Asiman, Zafar-Mashal, Garabagh, Inam, Alov-Araz-Sharg) and estimates probable reserves and timing of production. Marketing arrangements for and transportation of, the un-contracted gas is analysed in Section 7. Section 8 sets out the summary and conclusions. 

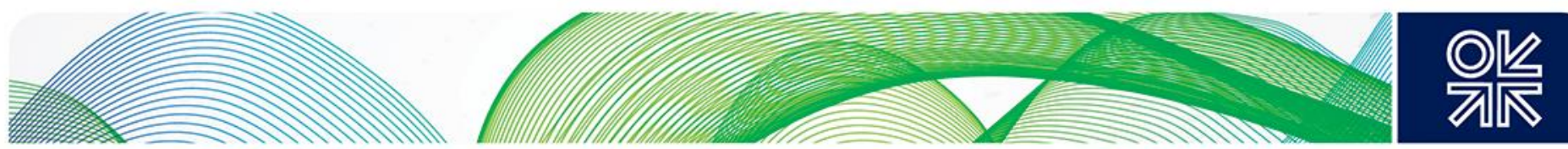

\section{Natural Gas in Azerbaijan - Historical Context}

Azerbaijan is a country that is impossible to imagine without oil and gas. This country is hydrocarbon rich and has a history of oil and gas production, transportation and refining stretching back to ancient times. Starting in the early $19^{\text {th }}$ century, a deep understanding of the oil business was developed by both local and foreign investors, which laid the basis for rapid industry development. It included production, processing, transportation and also chemical and petrochemical sectors. Gas does not have the same long pedigree as the oil industry, although gas was produced and consumed in the country starting from the $5^{\text {th }}$ century. During World War II and in the 1970s Azerbaijan's economy became gas based, with gas comprising $60 \%$ of energy inputs before the end of the Soviet era. The presence of foreign companies in the country's energy business is the legacy of various syndicates and societies legally formed by foreign companies in Baku in the $19^{\text {th }}$ century.

Offshore extraction was started for the first time in the world in 1803 in Baku, when Kasumbek Mansurbekov started extraction from two wells, located 18 and 30 metres from the shoreline off the Bibi-Heybat bay. The first offshore oil field ceased existence in 1825 as a huge storm ravaged all wells in the Caspian Sea. In the $19^{\text {th }}$ century, oil production in Baku exceeded oil production in the United States.

The oil deposits in the Absheron peninsula produced inflammable gases and inextinguishable flames which made this place an object of religious worship by the followers of Zoroaster (Zarathustra). These were the early manifestation of natural gas resources in Azerbaijan in ancient times. In the $5^{\text {th }}$ century, natural gas was found in the cliffs of the Caspian Sea shore and in Azerbaijan natural gas was used as a fuel for the first time in the world. Natural gas was extracted here in the $18^{\text {th }}$ century and was transported through pipes made from pottery and cane for use in lime burning, asphalt and copper melting.

\section{The first stage of Azerbaijan's oil and gas history (1846-1920)}

The Absheron peninsula, north of Baku, can boast of other important 'world first' events in the oil and gas industry. An example is drilling a well applying mechanical methods, which was first undertaken in 1847 for industrial oil exploration to a depth of 21 metres in the Baku settlement of Bibi-Heybat. This was the world's first successfully drilled oil well, marking the beginning of the oil industry in Azerbaijan. Thus, the drilling of deep oil wells began on the shores of the Caspian Sea, 13 years before deep drilling in the state of Pennsylvania (USA) which was initiated in 1859. The first deep drilling in Bibi-Heybat paved the way for intensive drilling of many wells after 1868 once official authorisation for drilling was granted.

This can be viewed as the start of the first stage of the country's oil history which lasted until 1920 when the country was sovietised.

After the abolition of the lease-out system in 1872, the oil wells became the property of the Russian State Treasury. The introduction of intensive drilling for oil extraction after 1869 boosted private investment in oil production. In 1872 a number of laws to regulate the oil industry were approved by the emperor Alexander the Second 6 . The laws included imposing taxes on oil fields and oil products as well as privatising the oil lease areas via auctions. Only $4 \%$ of total investment in the oil industry in the country belonged to national investors and $10 \%$ of the capital was mixed in the form of joint ventures. The rest belonged to foreign investors.

${ }^{6}$ Gorny Journal, 1872, \#3, p.20 

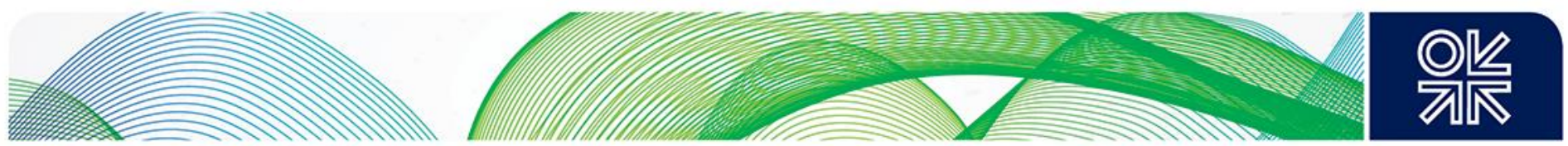

In 1901, 11 million tonnes of oil were produced in Azerbaijan. This constituted half of world oil production and $95 \%$ of all oil extraction in the Russian empire ${ }^{7}$ (Figure 1). In 1899-1910, Baku helped Russia to become the number one oil producer in the world, ahead of the USA, Argentina, Peru and others. $62 \%$ of oil extracted in the Russian Empire in 1914 as well as 2/3 of kerosene and mazut ${ }^{8}$ production had been produced by only the three companies - Oil, Shell and the Nobel Brothers".

Figure 1: Oil production in Azerbaijan 1870 - 1920 (Million tonnes)

Dynamics of oil production in Azerbaijan between 1870-1920

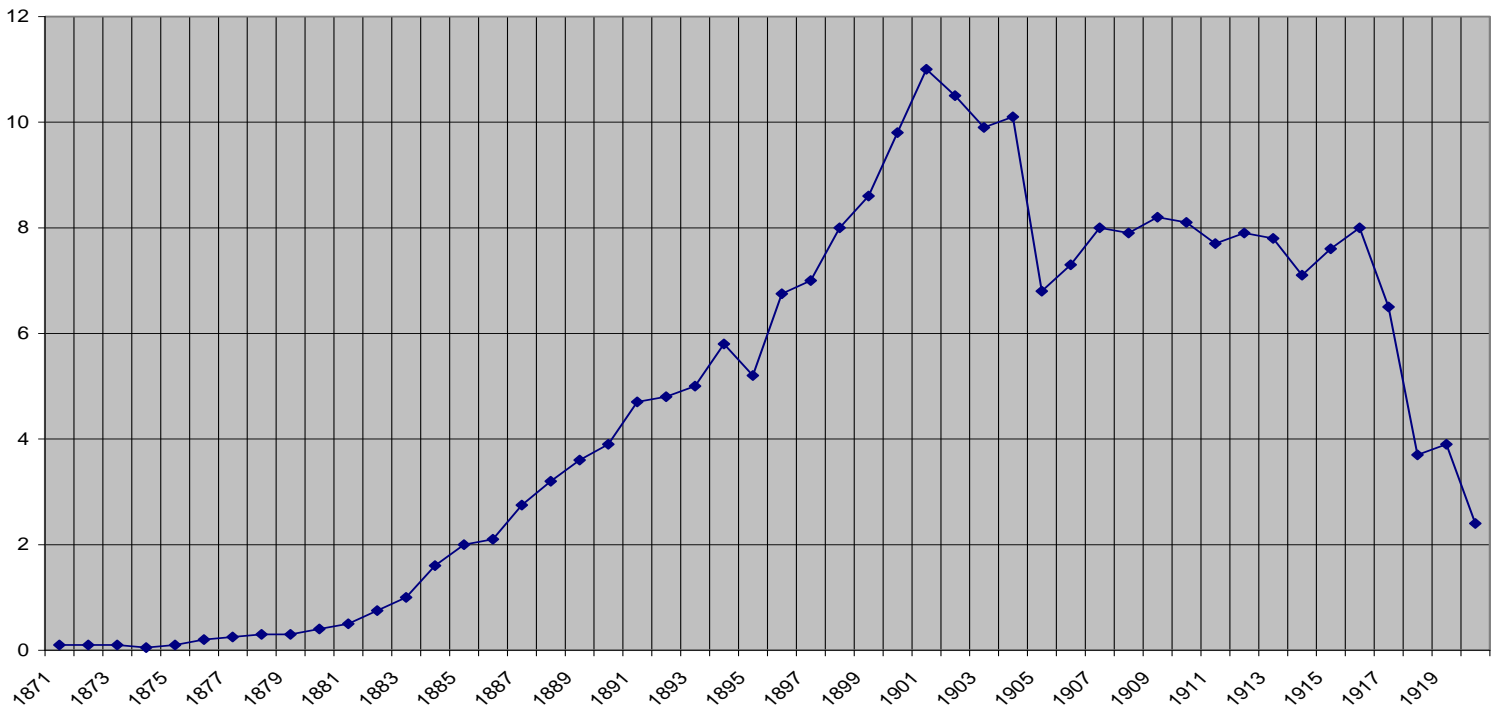

Source: Azerbaijan National Encyclopedia

In the second half of the $19^{\text {th }}$ century, natural gas began to be used in Azerbaijan in small plants to heat steam boilers. And in early 1902 in Surakhani "the Baku Oil Society" drilled the first natural gas well on its land plot.

During this period, the first pipeline for transportation of natural gas was laid and specific pumping stations were built in the Surakhani-Balakhani-Sabunchu areas. However, natural gas was mainly flared off because of the absence of the facilities necessary to store and transport it over long distances. In 1919, the total volume of gas consumed in Absheron was just $48 \mathrm{Mcm}^{9}$.

\section{The second stage of Azerbaijan's oil and gas history (1920-1949)}

The second stage of the country's oil and gas history started with the drastic drop in oil production resulting from the Russian revolution in 1917, which prevented further investment of foreign capital in Baku's oil industry (Figure 1). Azerbaijan gained its independence on May 281918 after the collapse of the Russian Empire and lost it as a result of the Red Army invasion on April 28 1920. In 1920 the Sovnarkom (government) of the Russian soviet republic (RSFSR) approved the "Nationalization of the Oil Industry". It declared the entire Russian oil industry the property of the people, and 272 private companies located and operating in the Baku region were liquidated. As a result of the sovietisation of Azerbaijan and nationalisation of the oil industry, oil production in the country dropped to 2.4 million tonnes in 1921 from some 8 million tonnes in 1916.

\footnotetext{
Azerbaijan National Encyclopedia, p. 411, Baku, 2007

${ }^{8}$ Heavy fuel oil

${ }^{9}$ Azerbaijan National Encyclopedia, p. 420, Baku, 2007
} 

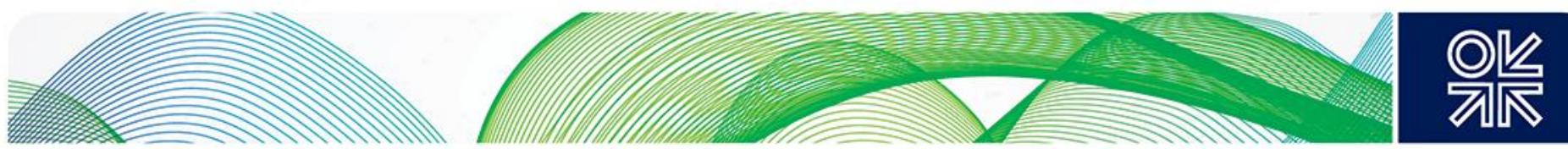

In order to manage the nationalised oil industry, revive the depressed economy and increase production, the government established Production Unit "Azerneft". As a result, in 1928 oil production was restored to the level of $1913-7.7$ million tonnes. Azerbaijan became the main oil producer of the USSR, providing more than $70 \%$ of its oil. In 1940, Azerbaijan produced 22.2 million tonnes of oil as a result of rapid upstream industry development. At this stage, exploration activity was intensified, and most of the currently known onshore and offshore fields were discovered. In 1941, in Bayil, near Baku, the world's first inclined wells were drilled to a depth of 2,000 metres. In the same year, oil production rose to 23.6 million tonnes. During World War II, Azerbaijan became a base for the supply of oil and oil products for military vehicles and equipment. The country provided more than 75 million tonnes/a of oil to the war effort, which constituted $75 \%$ of total USSR oil production ${ }^{10}$.

After the war, the biggest breakthrough was the discovery and exploitation of rich offshore oil deposits in the Caspian Sea. $40 \mathrm{~km}$ off the coast the legendary Oil Rocks was built, a whole city on iron piles, constructed in the open sea - the first such installation in the world. This moved Azerbaijan's oil production centre of gravity decisively offshore.

Although natural gas production in Azerbaijan in the 1920s was relatively modest, it increased by almost 18 times by the end of the 1930s (Figure 2). By 1940, natural gas production had increased by more than 14 times from the 1928 level to $2.5 \mathrm{bcm} / \mathrm{a}$. On the eve of the Second World War, Azerbaijan was by far the largest gas producer in the USSR, with an output of $2.5 \mathrm{bcm}$ out of a USSR total of $3.2 \mathrm{bcm}$ in $1940^{11}$. In the aftermath of the war, the exploration of the onshore fields "Garadagh", "Zire", "Siyazen", and the offshore field of "Bahar" was instrumental in the rapid development of Azerbaijan's gas industry.

Figure 2: Total natural gas produced between 1923 and 1932

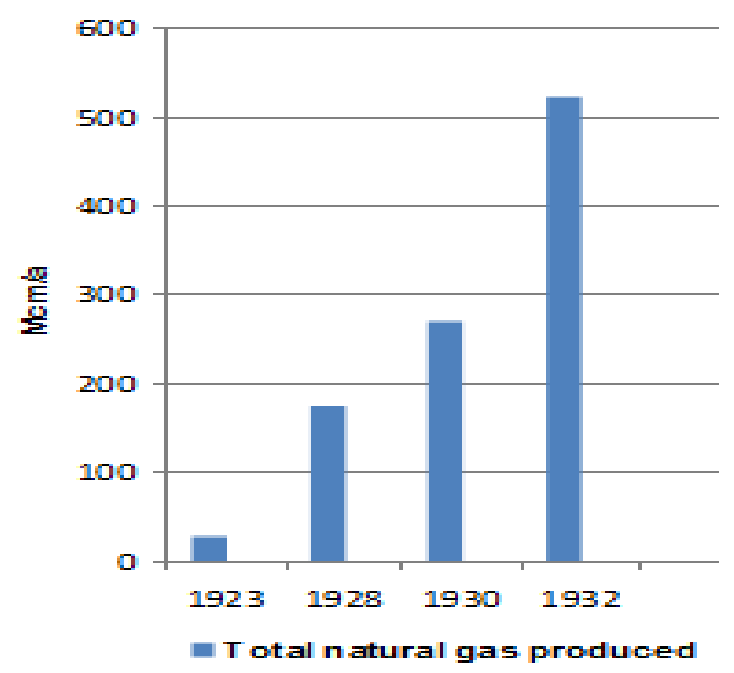

Source: Azerbaijan National Encyclopedia

The third stage of Azerbaijan's oil and gas history (1950-1969)

The development and expansion of offshore seismic surveys and exploration drilling, and the discovery of a number of new oil and gas fields, characterised this period. In the period 1958-1959, for the first time in the USSR floating rigs were used for exploration drilling. By 1954, associated gas became predominant in the natural gas output of Azerbaijan. An important event in the gas industry

\footnotetext{
${ }^{10}$ Azerbaijan National Encyclopedia, p. 412, Baku, 2007

11 "Azerbaijan: from gas importer to gas exporter", by Julian Bowden, chapter in: "Russian and CIS markets and their impact on Europe", Pirani et al (2009)
} 

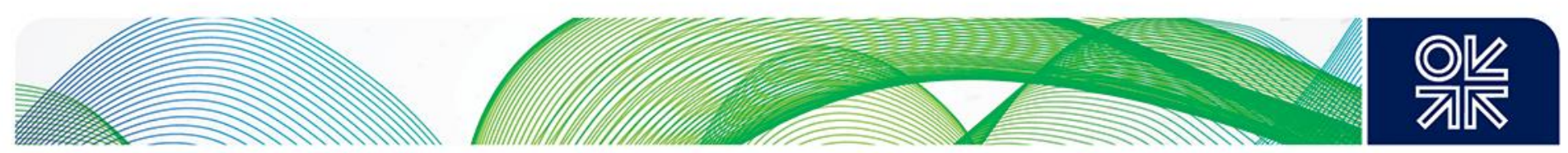

not only of Azerbaijan, but of the entire South Caucasus region was the exploration of the "Garadagh" onshore gas field in 1955.

Since the 1950s the Azerbaijani economy has been mainly based on oil and gas. Azerbaijan developed a relatively simple energy mix; one which it continues to the present day. It has no domestic coal production, and significant coal imports stopped in the 1950s when the power stations converted to heavy fuel oil. Natural gas production increased to $5.8 \mathrm{bcm}$ in 1960 but fell to $5.5 \mathrm{bcm}$ in $1970^{12}$. Table 2 shows Azerbaijani output increased in the 1960s, although even by the 1950s it had lost its number one production position in the USSR to rapidly increasing output in both Russia and Ukraine.

Table 2: Azerbaijan and USSR/CIS gas production 1940-2005 (bcm)

\begin{tabular}{|c|c|c|c|c|c|c|c|c|c|c|c|c|}
\hline & 1940 & 1945 & 1950 & 1960 & 1970 & 1980 & 1990 & 1995 & 2000 & 2005 & 2006 & 2007 \\
\hline 1 & 2 & 3 & 4 & 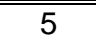 & 6 & 7 & 8 & 9 & 10 & 11 & 12 & 13 \\
\hline Russia & 0.2 & 1.5 & 2.9 & 24.4 & 83.3 & 254.0 & 640.6 & 595.0 & 584.0 & 641.0 & 6566.2 & 654.1 \\
\hline Belarus & & & & & 0.2 & 0.3 & 0.3 & 0.3 & 0.3 & 0.2 & 0.2 & 0.2 \\
\hline Ukraine & 0.5 & 0.8 & 1.5 & 14.3 & 60.9 & 56.7 & 28.1 & 18.2 & 17.9 & 20.8 & 21.1 & 20.4 \\
\hline Azerbaijan & 2.5 & 1.0 & 1.2 & 5.8 & 5.5 & 14.0 & 9.9 & 6.6 & 5.6 & 5.7 & 6.8 & 11.5 \\
\hline Georgia & & & & & & & & 0.003 & 0.1 & 0.01 & 0 & 0 \\
\hline Kazakhstan & 0.004 & 0.005 & 0.01 & 0.04 & 2.1 & 4.3 & 7.1 & 5.9 & 11.5 & 25.0 & 26.4 & 29.2 \\
\hline Turkmenistan & 0.01 & 0.01 & 0.1 & 0.2 & 13.1 & 70.5 & 87.7 & 32.3 & 47.2 & 63.0 & 66.7 & 72.3 \\
\hline Uzbekistan & 0.003 & 0.01 & 0.1 & 0.4 & 32.1 & 34.8 & 40.8 & 48.6 & 56.4 & 58.9 & 60.2 & 63.5 \\
\hline Tajikistan & 0.002 & 0.001 & & & 0.4 & 0.2 & 0.1 & 0.04 & 0.03 & 0.02 & 0.02 & 0.01 \\
\hline Kyrgyzstan & & & & 0.0 & 0.4 & 0.1 & 0.1 & 0.04 & 0.03 & 0.02 & 0.02 & 0.01 \\
\hline $\begin{array}{l}\text { Total } \\
\text { USSR/CIS }\end{array}$ & 3.2 & 3.3 & 5.8 & 45.2 & 198.0 & 435.2 & 814.8 & 707.0 & 723.1 & 814.7 & 837.7 & 851.2 \\
\hline
\end{tabular}

Source: Bowden (2009), OIES

The fourth stage of Azerbaijan's oil and gas history (1969-1991)

The use of natural gas in households and industry helped to save more than 13 million tonnes/year of mazut in the mid 1950s (40 million tonnes in total).

During this period offshore oil and gas fields were discovered, generally in water depths of about 40 metres. Starting from the 1970s, the semi-submersible floating drilling rig named "Shelf" was used. It made it possible to conduct exploration work at depths up to 200 metres. As a result, eight new oil and gas fields were discovered, oil reserves were doubled and gas reserves were tripled. In the 1980 s the number of floating drilling rigs reached 11 . Their application provided the opportunity to conduct exploration drilling in water depths of $80-350 \mathrm{~m}$. As a result, the largest of Azerbaijan's oil fields "Azeri", "Chirag" and "Guneshli" were discovered.

During the Soviet period Azerbaijan could be said to have been a pioneer of USSR consumption of gas in industrial applications, which in other countries might be dominated by coal and oil products. With the template of high gas penetration in Azerbaijan's energy mix, the massive development of the Russian West Siberian discoveries in the 1970s, carried little domestic market risk as there was no doubt that large volumes of gas, at least initially, could be consumed. Production and transportation, rather than demand were the major risks.

${ }^{12}$ Azerbaijan National Encyclopedia, p. 421, Baku, 2007 

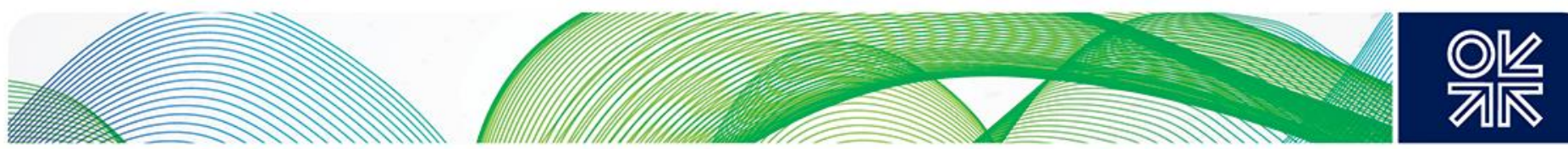

Azerbaijan's natural gas consumption up to the 1990s was extremely inefficient and there were significant losses in the transportation and distribution system. To meet its gas consumption requirements, which by then exceeded domestic production, Azerbaijan started to import gas from Iran. Imports began in the late 1960s and early 1970s to ensure energy security not only in Azerbaijan, but also Georgia and Armenia, which received natural gas from Azerbaijan through the Nagorno-Karabakh territory.

The 42-inch Iran-Astara-Gazimammed-Gazakh pipeline, with $10 \mathrm{bcm} / \mathrm{a}$ of capacity, was constructed between Bid Boland Refinery in Khuzestan Province and Astara in northern Iran. IGAT ${ }^{13} 1$ was completed in October 1970, to supply the Southern Caucasus republics of the Soviet Union. Under the arrangement, the Soviet Union imported $1.0 \mathrm{bcm} / \mathrm{a}$ which grew rapidly to $8.7 \mathrm{bcm} / \mathrm{a}$ by 1973 and remained at the 9.0-9.5 bcm/a level until 1978, to enable the Soviet Union to export gas to Czechoslovakia from its own gas fields in Siberia.

Construction of IGAT II was halted following the Iranian Revolution in 1978. This pipeline had been planned to help meet growing gas consumption in the Caucasus region. With gas consuming plant already being installed, the termination of Iranian imports meant a new pipeline had to be built quickly from Russia into Azerbaijan, to replace the lost Iranian volumes with Russian gas. In 1980 the Mazdok-Gazimammed gas pipeline was built to import gas from Russia. In 1982, gas production in Azerbaijan reached a maximum level of $14.9 \mathrm{bcm} / \mathrm{a}$ and most parts of the country by the 1980s were gasified (Figure 3). For the first time in the USSR, underground gas storage was created in Azerbaijan, ensuring natural gas supply to the domestic gas consumer in an uninterruptable and stable manner all year round.

Figure 3: Natural gas production in Azerbaijan, 1950-1990 (bcm)

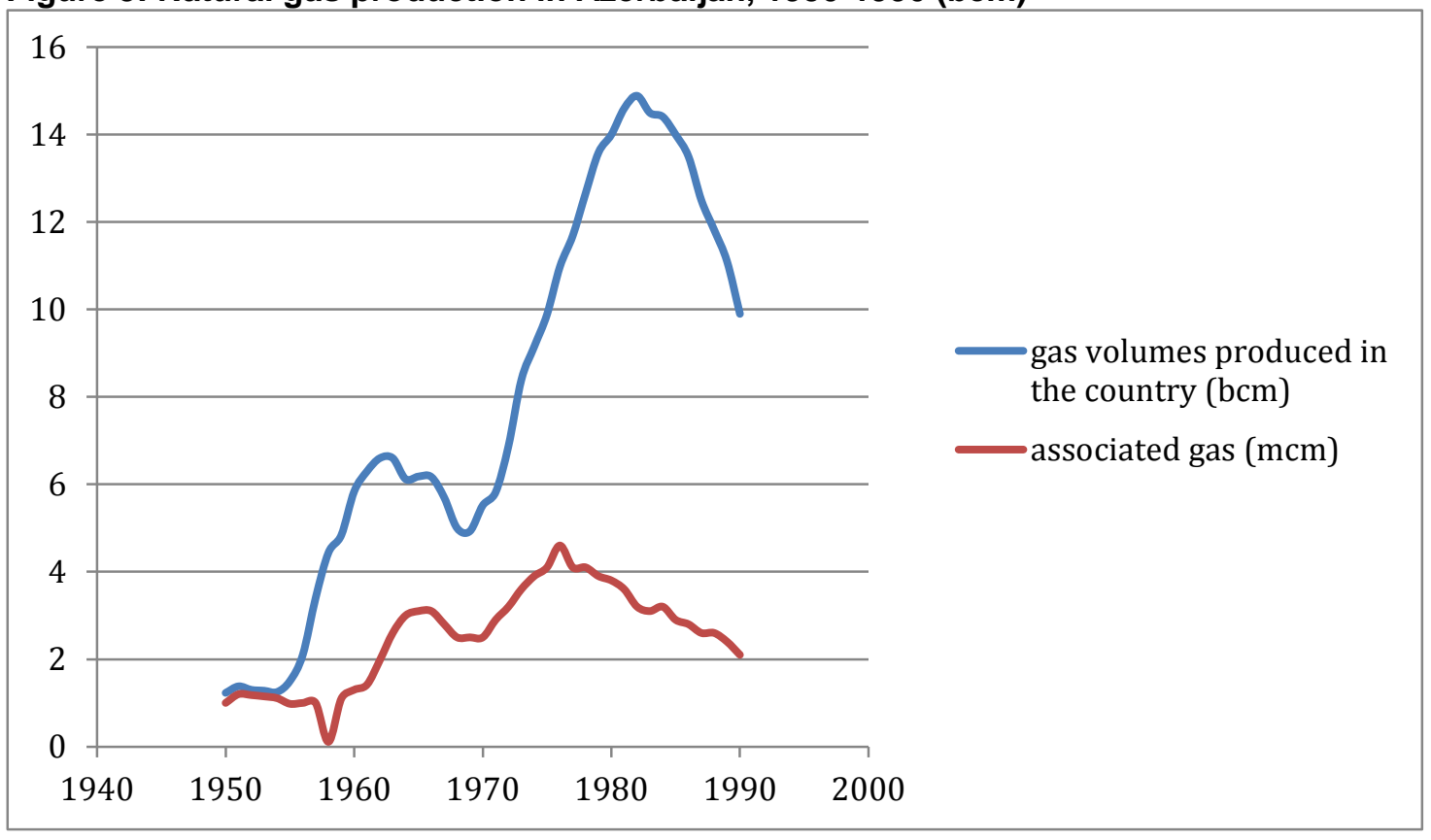

Source: The State Statistical Committee of the Republic of Azerbaijan (SSCRA)

Note: Associated gas is not included in the plot of gas volumes produced in the country

\section{The fifth stage of Azerbaijan's oil and gas history (from 1991)}

This stage of the oil and gas history of Azerbaijan started with the collapse of the Soviet Union and regaining of independence on October $18^{\text {th }} 1991$. The break-up of the USSR at the end of 1991 led to 

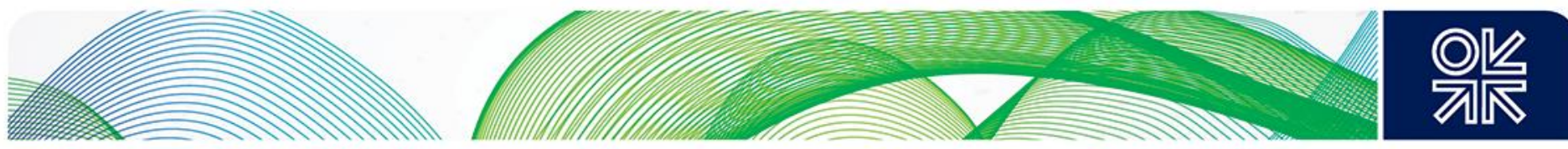

massive structural change. Initially all the region's economies went into steep decline as trading relationships broke down. Azerbaijan's GDP collapsed, the economy shrinking almost $60 \%$ between 1990 and 1995. However, despite the political and economic turmoil, Azerbaijan entered a new stage of energy industry development, involving a number of foreign energy majors and billions of US dollars of investments in the country's upstream and midstream projects, a dynamic similar to that witnessed in the $19^{\text {th }}$ century during the first Azerbaijan oil boom.

Azerbaijan's oil strategy, initiated and adopted in early 1990s by the then president Heydar Aliyev (1993-2004), was based on: attracting foreign investments; turning the country into one of the major oil exporters in the region (in the first stage of the energy strategy); turning the country into a strategically important natural gas exporter for the neighboring countries as well as for Europe in the longer run (in the second stage of the strategy); and turning the country into an important transit country for transportation of mainly Central Asian hydrocarbons (both oil and gas) in the longer term, when the indigenous production of hydrocarbons was depleting ${ }^{14}$. It also included the objective of domestic energy security for the foreseeable future by becoming an energy-self-sufficient country. Thus the important role that Azerbaijan should play, in accordance with the oil strategy, is to provide energy security to neighboring countries such as Georgia and Turkey, but also the European Union.

The politically unstable situation in the country immediately after regaining independence, the lack of financial investment and the shortage of advanced technologies halted the development of the offshore "Azeri", "Chirag" and "Guneshli" fields which had already been discovered. In order to address the on-going crisis in the oil industry and to begin development of the country's energy resources, President Heydar Aliyev invited international oil companies to Azerbaijan to provide the necessary impetus. As a result of the negotiations with 11 foreign companies from 7 different countries, the so-called "Contract of the Century" was signed on September 20th 1994 for the development of the contiguous "Azeri-Chirag-Guneshli" (ACG) suite of fields, which had a historic significance for the economic well-being of the country for decades to come.

According to preliminary estimates, possible recoverable oil reserves of the field stood at 511 million tonnes. After further reservoir valuation based on data obtained from development wells, oil reserves were upgraded towards 730 million tonnes. The latest assessment in 2006 resulted in a figure of 924 million tonnes.

According to the signed contract, starting from 2008 the total net profit from oil export, after the recovery of capital and operating costs, is distributed as $80 \%$ to the Republic of Azerbaijan and $20 \%$ to the International Oil Companies (IOCs). The IOCs also pay taxes on their $20 \%$ profit.

For the implementation of the "Contract of the Century", the Azerbaijan International Operating Company (AIOC) was established. This operating company works closely with the State Oil Company of Azerbaijan (SOCAR). Later, the "Contract of the Century" paved the way for the conclusion of other contracts with 42 oil majors from 19 countries, investing billions of US dollars in exploitation and development of the Azerbaijani sector of the Caspian Sea.

After Azerbaijan regained independence and throughout the 1990s, the gas industry experienced massive restructuring. In the early 1990s, despite its large hydrocarbon resource base, Azerbaijan's major problem was that it had become a net importer of both oil and gas, importing $6.5 \mathrm{bcm} / \mathrm{a}$ of gas from Russia. Gas production fell steadily throughout the 1990s (Table 3 ) due to lack of sustaining investment. 

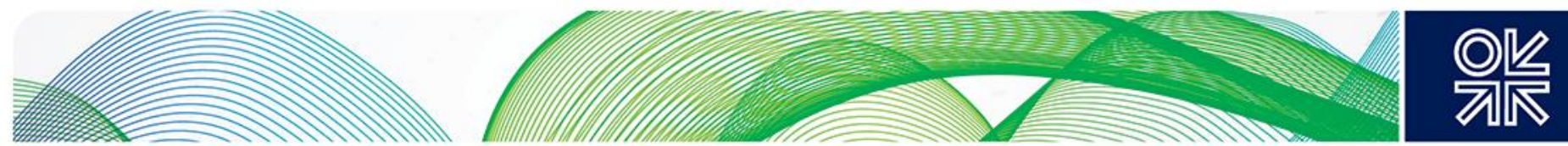

Table 3: Natural gas production in Azerbaijan 1990-2013

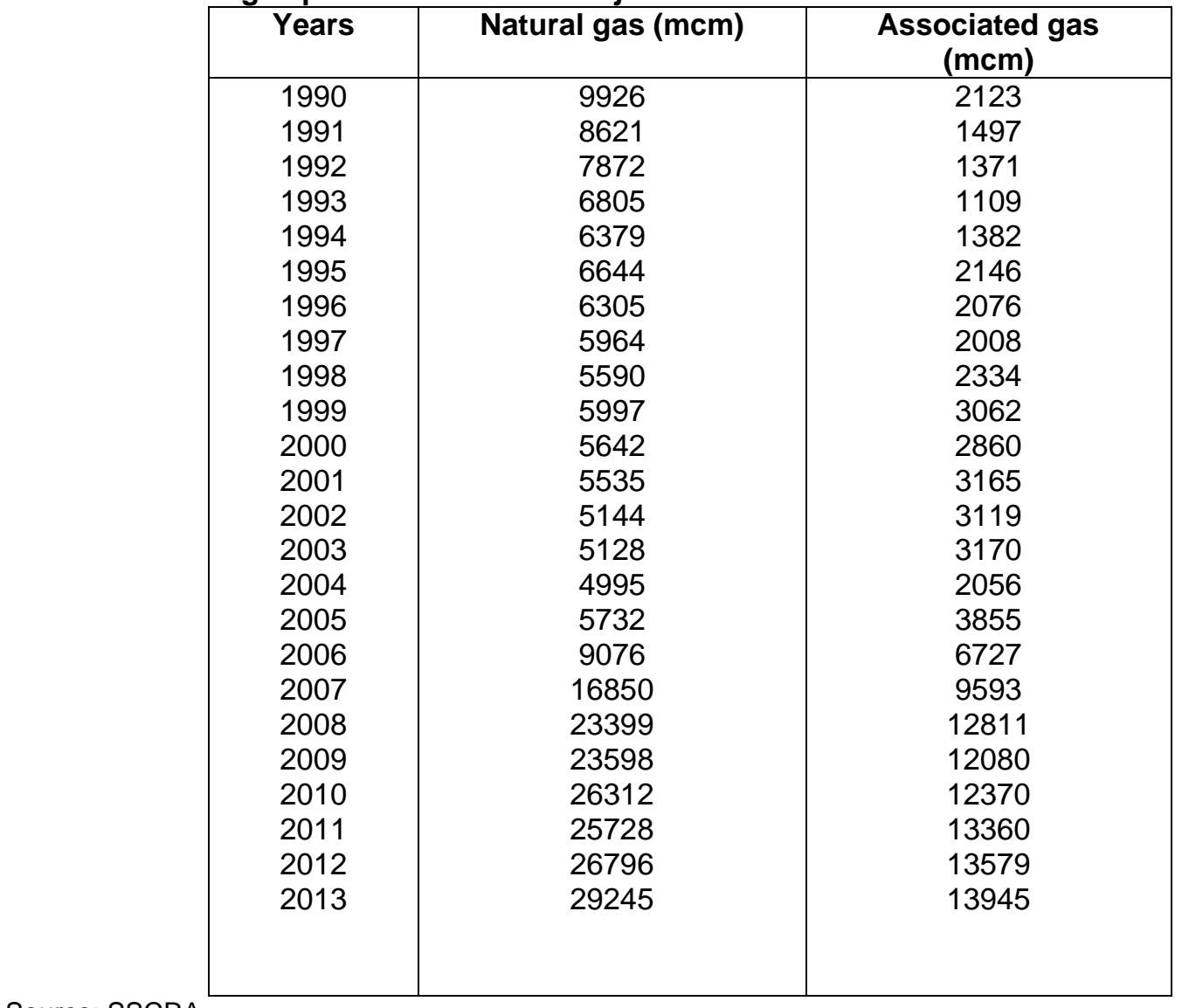

Source: SSCRA 

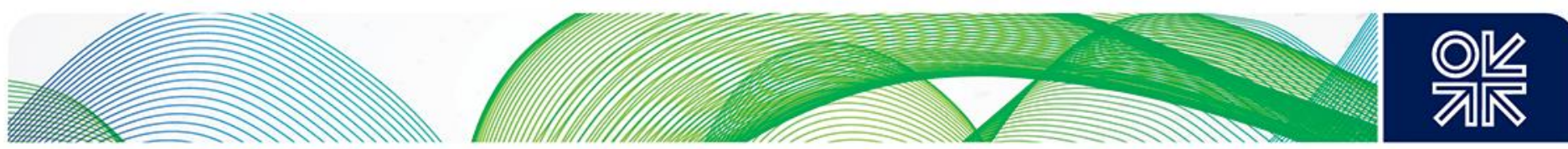

\section{Outlook for Azerbaijan Gas production and Exports: Shah Deniz Phases 1 and 2}

Azerbaijan's natural gas production between now and 2030 will comprise two groups of reserves and resources: (i) contracted gas; and (ii) uncontracted gas, so called "free gas" that will show a growing surplus, potentially available for new exports. This section will focus on the production outlook for already contracted gas from existing fields and fields that have achieved FID, namely Shah Deniz Phases 1 and 2.

Table 4: Azerbaijan gas production balance 2006 - 2013 (bcm)

\begin{tabular}{|l|c|c|c|c|c|c|c|c|}
\hline & $\mathbf{2 0 0 6}$ & $\mathbf{2 0 0 7}$ & $\mathbf{2 0 0 8}$ & $\mathbf{2 0 0 9}$ & $\mathbf{2 0 1 0}$ & $\mathbf{2 0 1 1}$ & $\mathbf{2 0 1 2}$ & $\mathbf{2 0 1 3}$ \\
\hline Production Total & 9 & 16.8 & 23.4 & 23.6 & 26.3 & 25.7 & 26.8 & 29.2 \\
\hline Reinjected \& flared & 3 & 6.1 & 7.1 & 7.3 & 9.6 & 8 & 7.5 & 7.9 \\
\hline Production(sales gas) & 6 & 10.8 & 16.3 & 16.3 & 16.7 & 17.7 & 19.3 & 21.3 \\
\hline
\end{tabular}

Source: SSCRA, industry information, OIES

\subsection{Shah Deniz Phase 1}

Azerbaijan's earliest discovered gas reserves are largely concentrated in the Absheron-Pribalkhan Trough and the South Caspian Deepwater Basin. The South Caspian Deepwater Basin is at an early stage of exploration and development and currently contains around $75 \%$ of Azerbaijan's remaining commercial gas reserves. The Shah Deniz discovery, in the South Caspian Deepwater Basin, is Azerbaijan's most important gas field with commercial gas reserves of $1.2 \mathrm{tcm}$, and some of this has been already contracted. The current output comprises almost $9 \mathrm{bcm} / \mathrm{a}$ of gas contracted for Phase 1 and up to $17 \mathrm{bcm} / \mathrm{a}$ contracted for Phase 2.

A significant event in the country's gas production history took place in 1999, when the giant Shah Deniz gas and condensate field was confirmed. It is located offshore in the southern part of the Caspian Sea, in the Azerbaijani sector, approximately $70 \mathrm{~km}$ southeast of Baku, at a water depth of 600 metres. The field covers approximately 860 square $\mathrm{km}$, and is similar in size and shape to Manhattan Island (Map 1). 

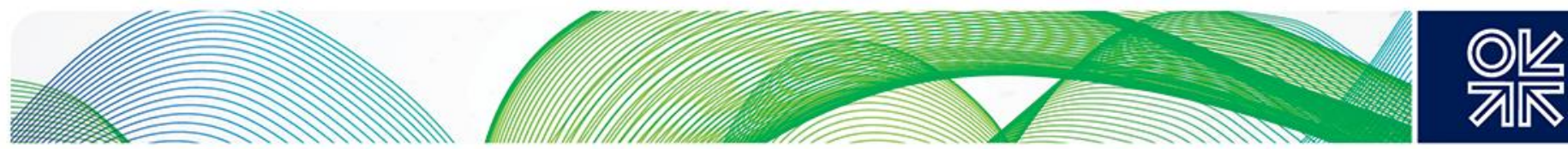

\section{Map 1: Location of the Shah Deniz field}

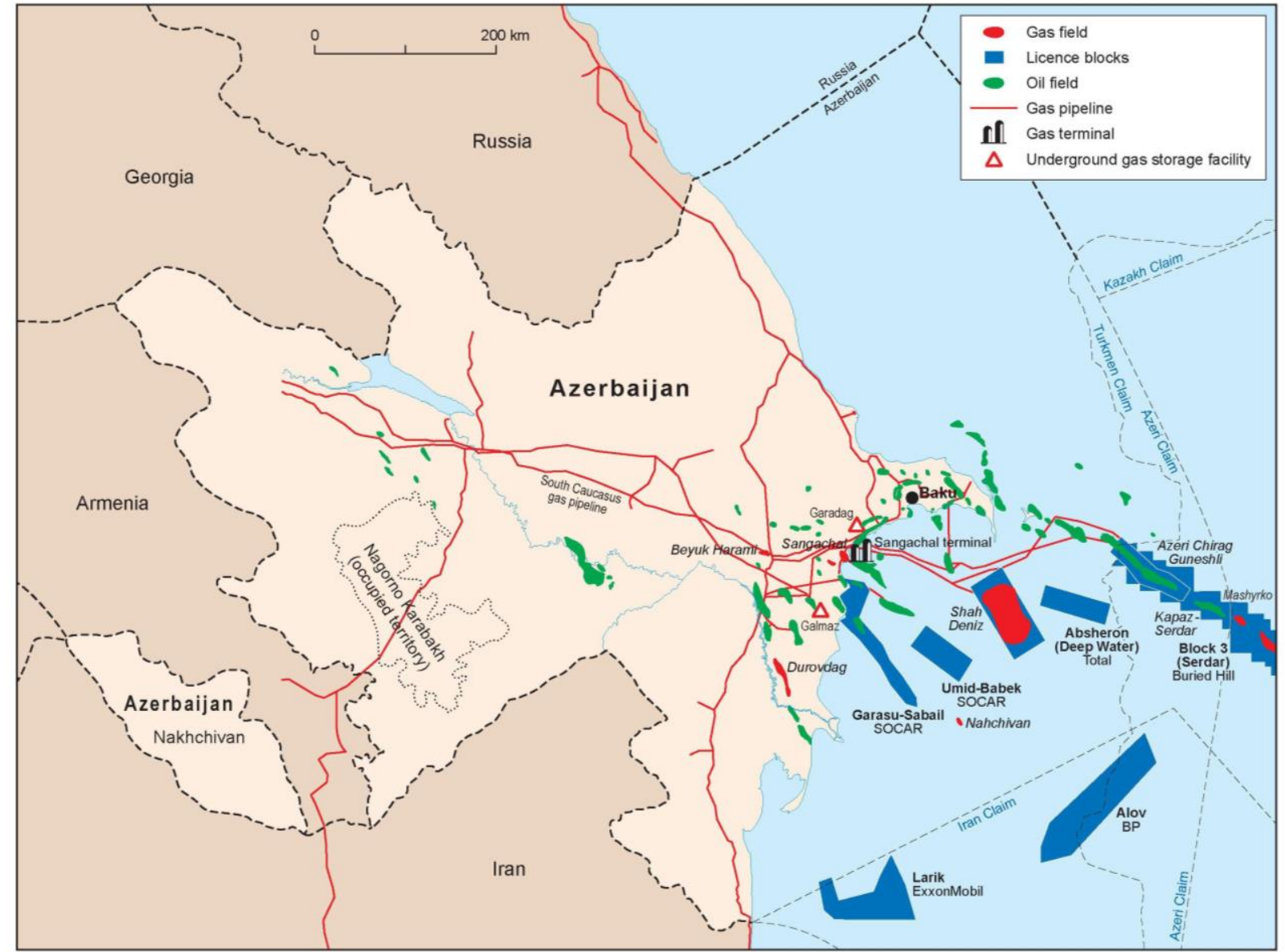

Source: OIES

As a result, Azerbaijan, as well as being a notable oil producer, regained the status not only of a growing gas producer, but also that of gas exporter. In doing so it enhanced its role in the provision of energy security in the region. Production from the Shah Deniz Phase 1 (SD1) field development was the first commercial natural gas exported from Azerbaijan to Georgia and Turkey.

A production sharing agreement (PSA) for SD1 was signed by SOCAR, BP Exploration (Azerbaijan) Limited, Elf Petroleum Azerbaijan B.V., LukOil International Ltd, Oil Industries Engineering and Construction, Statoil Azerbaijan A.S. and Turkish Petroleum Overseas Company Limited in 1996. It was followed by the first commercial gas production: the first commercial gas contract was signed on June $4^{\text {th }}$ 1996. This agreement was ratified by the National Parliament of Azerbaijan on October $17^{\text {th }}$ 1996. The total area under the agreement ( 859.8 square $\mathrm{km}$ ), required three appraisal wells to be drilled. In order to conduct exploration and development activities, the "Shah Deniz" Exploration and Production operating company was established. The companies that signed the PSA and their shares are shown in Figure 4. 

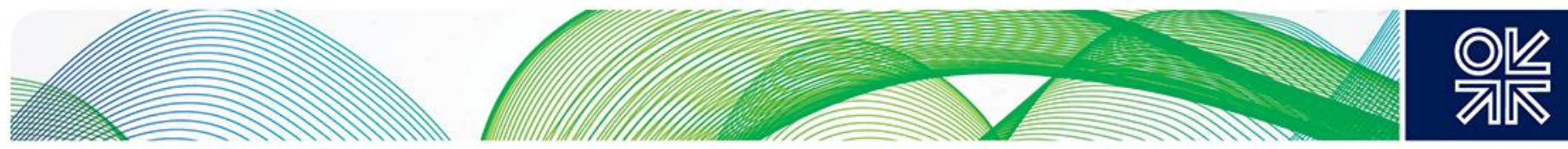

Figure 4: Shah Deniz Production Sharing Agreement: Shareholders and stakes (\%)
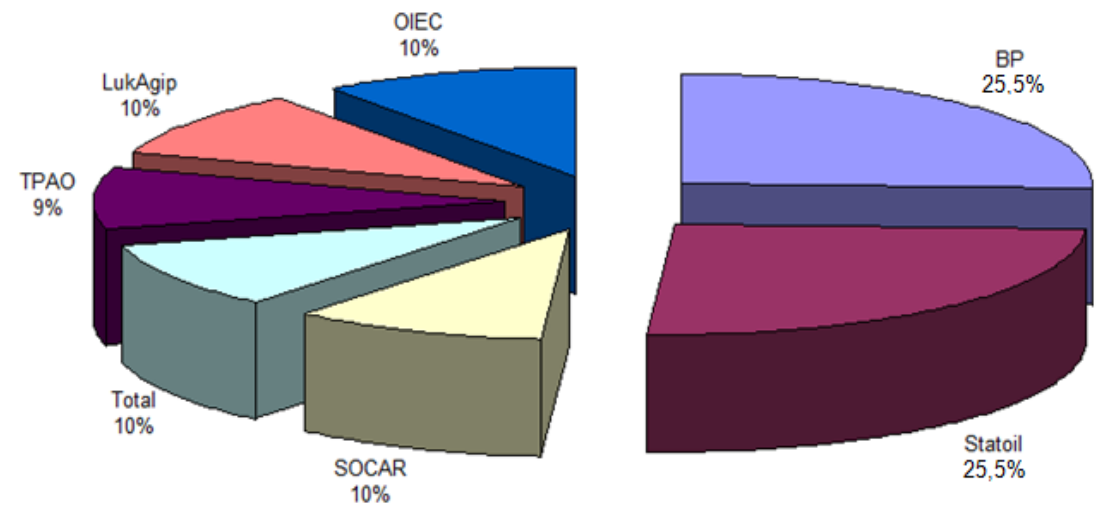

Source: BP

(The PSA was signed in 1996 and changed in December 2013 and November 2014. See SD2 sub-section.)

According to the contract the exploration, development and production timeframe is 30 years (until 2027) which can be extended for another 5 years. In 1999, the first wells were drilled with the existing "Dede Gorgud" and "Istiglal" (former Shelf-5 rig) drilling rigs. A $660 \mathrm{~mm}$ diameter underwater pipeline for gas and $305 \mathrm{~mm}$ pipeline for condensate was built, connecting the field production platform and the Sangachal Terminal. The Sangachal terminal was expanded and a new Baku-Tbilisi-Erzurum gas pipeline (or South Caucasus Pipeline (SCP) was laid, parallel to the Baku-Tbilisi-Ceyhan oil pipeline, to export gas to Georgia and Turkey. The Intergovernmental Agreement (IGA) and related accord for the transit, transportation and sale of natural gas was signed by Azerbaijan and Georgia in September 2001.

The IGA and a Sale and Purchase Agreement with Turkey were signed in March 2001 in Ankara. In March 2002, a Host Governmental Agreement (HGA) between the Government of Georgia and the SD partners for the transit, transportation and sale of natural gas was signed, marking the transition into the final stage of engineering, tendering and commercial development work. A parallel agreement was signed by the Government of the Republic of Azerbaijan and the SD partners in February 2002. ${ }^{15}$

Shah Deniz Phase 1 field development gas production started up on December 152006 . Between the start of production and the end of the third quarter of 2014 , about $55.2 \mathrm{bcm}$ of gas, and about 113.3 million barrels (14.2 million tonnes) of Shah Deniz condensate was produced ${ }^{16}$.

In the first stage of the project, it was planned to export $6.6 \mathrm{bcm} / \mathrm{a}$ of gas to BOTAŞ (Turkey), 0.8 $\mathrm{bcm} / \mathrm{a}$ to Georgian International Oil Corporation and $1.5 \mathrm{bcm} / \mathrm{a}$ to SOCAR. SD1 gas started flowing to Turkey on July $14^{\text {th }} 2007$.

Since 2006, Azerbaijan has become self-sufficient in gas and halted its gas imports from Russia (Figure 5). SD1 has the capacity to produce about $9 \mathrm{bcm} / \mathrm{a}$ of natural gas and approximately 50,000 barrels/day of condensate. The Shah Deniz partners have invested $\$ 8.224$ billion in total in Phase 1 field development since 2003 ${ }^{17}$. Since the start of Shah Deniz field production in late 2006 up to the

\footnotetext{
${ }^{15}$ Project Timeline, BP official website: http://www.bp.com/en az/caspian/operationsprojects/Shahdeniz/projecthistory.html

${ }^{16}$ Shah Deniz Stage 1, BP's official website: http://www.bp.com/en az/caspian/operationsprojects/Shahdeniz/SDstage1.html 17“Total Investment in Shah Deniz Gas Field at \$11.4 Billion”, Natural Gas Europe, http://www.naturalgaseurope.com/shahdeniz-gas-field-investments-profit, 19 November 2014
} 
end of the first quarter of 2014, about $50.3 \mathrm{bcm}$ of gas, and about 104 million barrels of oil (over 13 million tonnes) have been produced ${ }^{18}$.

Figure 5: Azerbaijan natural gas production and consumption 2003-2013 (bcm/a)

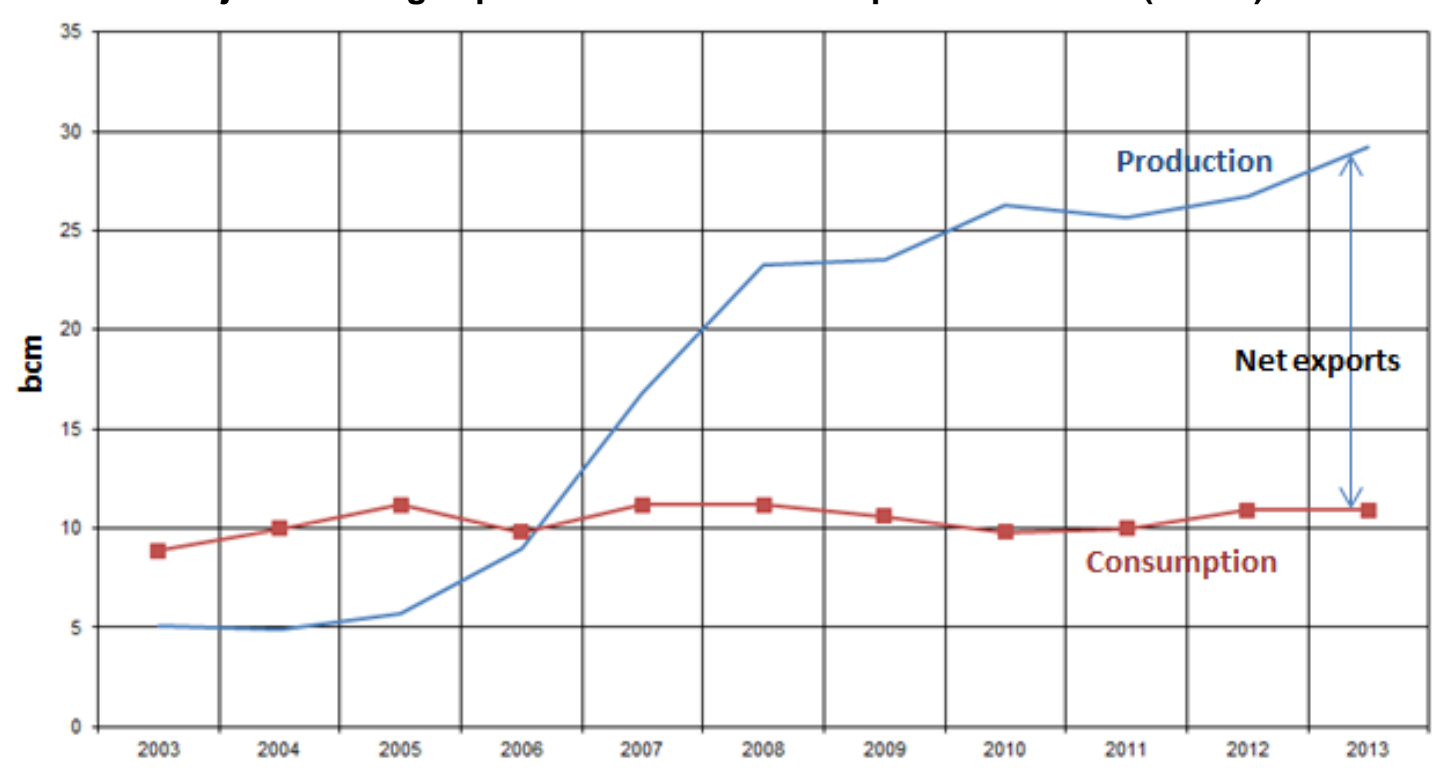

Source: SSCRA

The SD consortium holds supply contracts with buyers in three countries to provide gas from the first stage of the field: Turkey, Georgia, and Azerbaijan (Figure 6).

Figure 6: The natural gas volumes contracted under Shah Deniz Phase 1 (bcm/a)

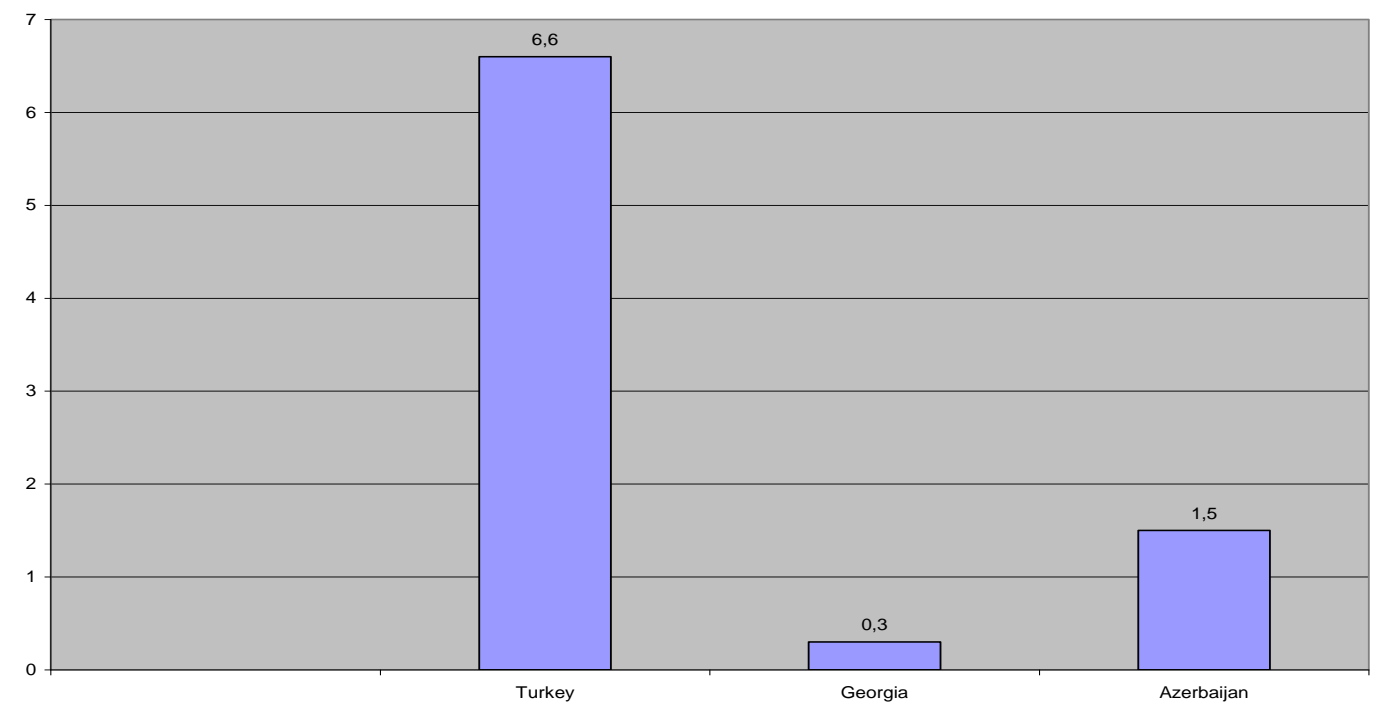

Source: Author, SOCAR, BP

${ }^{18}$ Shah Deniz Stage 1, BP's official website: http://www.bp.com/en az/caspian/operationsprojects/Shahdeniz/SDstage1.html 

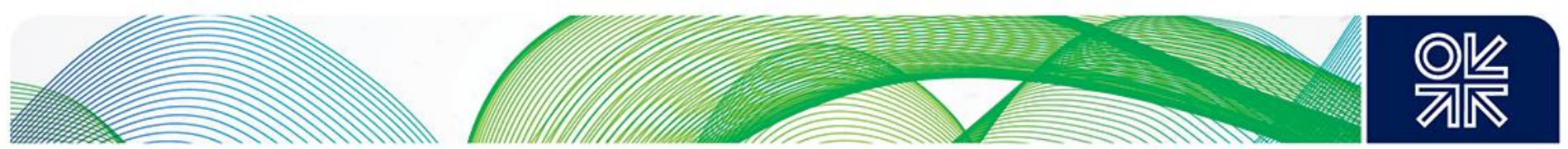

The $6.6 \mathrm{bcm} / \mathrm{a}$ gas supply contract to Turkey will expire in $2021^{19}$. However, the actual volume of SD1 gas taken by BOTAŞ has been less than that contracted. Thus far, BOTAŞ has never been able to take all the contracted volumes from supply sources to the east of Turkey (Azerbaijan and Iran), because of insufficient capacity in the BOTAŞ transmission system, specifically a shortage of compression capacity ${ }^{20}$. Only $30 \mathrm{bcm}$ of gas has been exported to Turkey in total from July 2007 till October $2014,{ }^{21}$ giving an average offtake from Azerbaijan of $4.2 \mathrm{bcm} / \mathrm{a}^{22}$. The volume of gas offtaken in 2010 was $4.5 \mathrm{bcm}^{23}$, in $2011-3.8 \mathrm{bcm}^{24}$, in $2012-3.4 \mathrm{bcm}^{25}$ and in $20134.2 \mathrm{bcm}^{26}$. BOTAŞ has been able to take almost $90 \%$ of natural gas coming from the Western Line and Blue Stream but overall has had to pay billions of dollars for untaken volumes, effectively increasing the price of imports from Azerbaijan and Iran. This problem is likely to be solved with the construction of two compressor stations at Hanak and Erzrum as well as with contraction of TANAP pipeline. In the contracts with the SD1 consortium the imported gas price depends on the percentage of gas actually taken: taking all the contracted gas results in a lower average price.

It is not known whether the extension of the supply contract between BOTAS and the SD consortium for SD1 gas will be extended beyond 2021. The Turkish Natural Gas Market Law prohibits the Turkish monopolist from renewing the existing contracts. Despite this, BOTAŞ has signed new import contracts contrary to the provisions of the Law with the agreement of the Council of Ministers, to ensure security of supply.

Turkey's gas demand is growing rapidly and by 2021, if the SD1 contract is not extended, its contracted supply shortfall may be around $10-15 \mathrm{bcm} / \mathrm{a}^{27}$. At the moment for Turkey, gas from Azerbaijan is the best option to fill the gap, due to the lower price Turkey pays relative to other contracted import sources. One reason that Turkey may not want to extend the contract is the possible emergence of cheaper gas from the Kurdistan Regional Government (KRG) in Iraq at some point in the period to 2020. However, gas production and export from KRG is fraught with political complexities that are unlikely to be resolved any time soon.

Increasing imports of gas from Russia could be another option, if Turkey succeeds in negotiating a better price. The MOU signed in December 2014 to increase the volume of import from Russian Blue Stream by up to $3 \mathrm{bcm} / \mathrm{a}$ from January 2015, is to cover the gas supply gap in 2015-2016, that is most likely to occur due to Turkish demand growth and no available import of additional volumes. In January 2015, Gazprom and BOTAŞ agreed to build the Turkish Stream pipeline that will substitute for the abandoned South Stream project and bring Russian gas to western Turkey. The primary purpose of this line is to re-route gas volumes that are transited via Ukraine, but it could bring additional Russian gas to Turkey at some point in the 2020s. (See discussion in Section 7 below).

\footnotetext{
${ }^{19}$ BOTAS Natural gas sale and purchase agreements, http://www.botas.gov.tr/index.asp

${ }^{20}$ Rzayeva (2014), OIES

http://www.oxfordenergy.org/2014/02/natural-gas-in-the-turkish-domestic-energy-market-policies-and-challenges/

21 “Total Investment in Shah Deniz Gas Field at \$11.4 Billion”, Natural Gas Europe, http://www.naturalgaseurope.com/shahdeniz-gas-field-investments-profit, 19 November 2014

${ }^{22}$ Average offtake volume is $4.2 \mathrm{bcm}$ (30 bcm: 7 years)

${ }^{23}$ Annual Natural Gas Market Sector Report 2010, EMRA (Turkish Market Regulatory Authority), (available in Turkish),

http://www.epdk.org.tr/documents/dogalgaz/rapor yayin/Dpd Rapor Yayin Sektor Raporu 2010 Son Hali.pdf

${ }^{24}$ Annual Natural Gas Market Sector Report 2011, EMRA,

http://www.emra.org.tr/documents/natural gas/publishments/NaturalGasMarket2011SectorReport Q9WwGbRxxnRy.pdf

${ }^{25}$ Annual Natural Gas Market Sector Report 2012, EMRA (Turkish Market Regulatory Authority),

http://www.epdk.org.tr/documents/dogalgaz/rapor yayin/Ddp yayin rapor 2012.pdf, (available in Turkish)

${ }^{26}$ Annual Natural Gas Market Sector Report 2013, EMRA, (available in Turkish)

http://www.epdk.org.tr/documents/dogalgaz/rapor yayin/Dpd Rapor Yayin Sektor Raporu 2013.pdf

27"Natural Gas in the Turkish Domestic Energy Market: Policies and Challenges",

http://www.oxfordenergy.org/2014/02/natural-gas-in-the-turkish-domestic-energy-market-policies-and-challenges/
} 

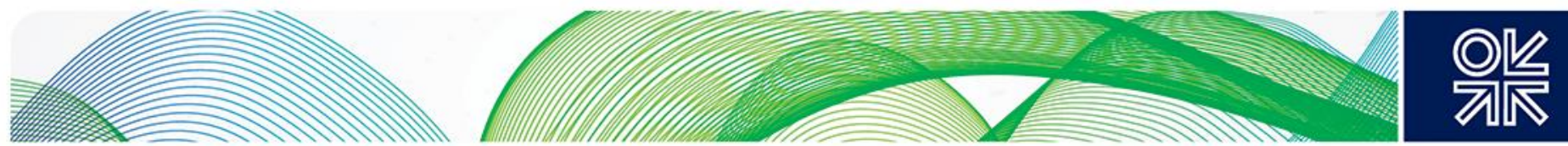

As the result of nearly two years' deadlock in negotiations between Azerbaijan and Turkey, a package of gas agreements between the countries was finally signed on October $26^{\text {th }} 2011$ in Izmir, during an official visit of the President of Azerbaijan to Turkey. The agreement deals with the following:

a) The natural gas price for volumes from SD1.

b) The natural gas volume/price for gas from SD2.

c) Other volumes of gas from the Azerbaijani gas production portfolio for possible export to, or via, Turkey were also provided for by the agreement. These included 2 bcm for 2017; 2018 $4 \mathrm{bcm} ; 2019$ - $6 \mathrm{bcm}$; transit through Turkey (gas from SD2, SOCAR's own portfolio and other ventures); Azerbaijani gas to Syria (1-1.5 bcm/a) ${ }^{28}$;Azerbaijani gas to Jordan (up to 1 bcm/a) ${ }^{29}$; Azerbaijani gas to Greece (up to $1 \mathrm{bcm} / \mathrm{a}$ ); Azerbaijani gas to Bulgaria (up to 1 $\mathrm{bcm} / \mathrm{a}$ ); Azerbaijani gas to Petkim facilities in Turkey (up to $0.8 \mathrm{bcm} / \mathrm{a}$ ).

d) Transit tariffs for gas to be transported through Turkish territory and the BOTAŞ system. The Turkish side agreed to unify the transit tariff, i.e. not differentiating according to the destination of the gas.

Figure 7: The natural gas exports (delivered volumes) from SD1, 2007-2013

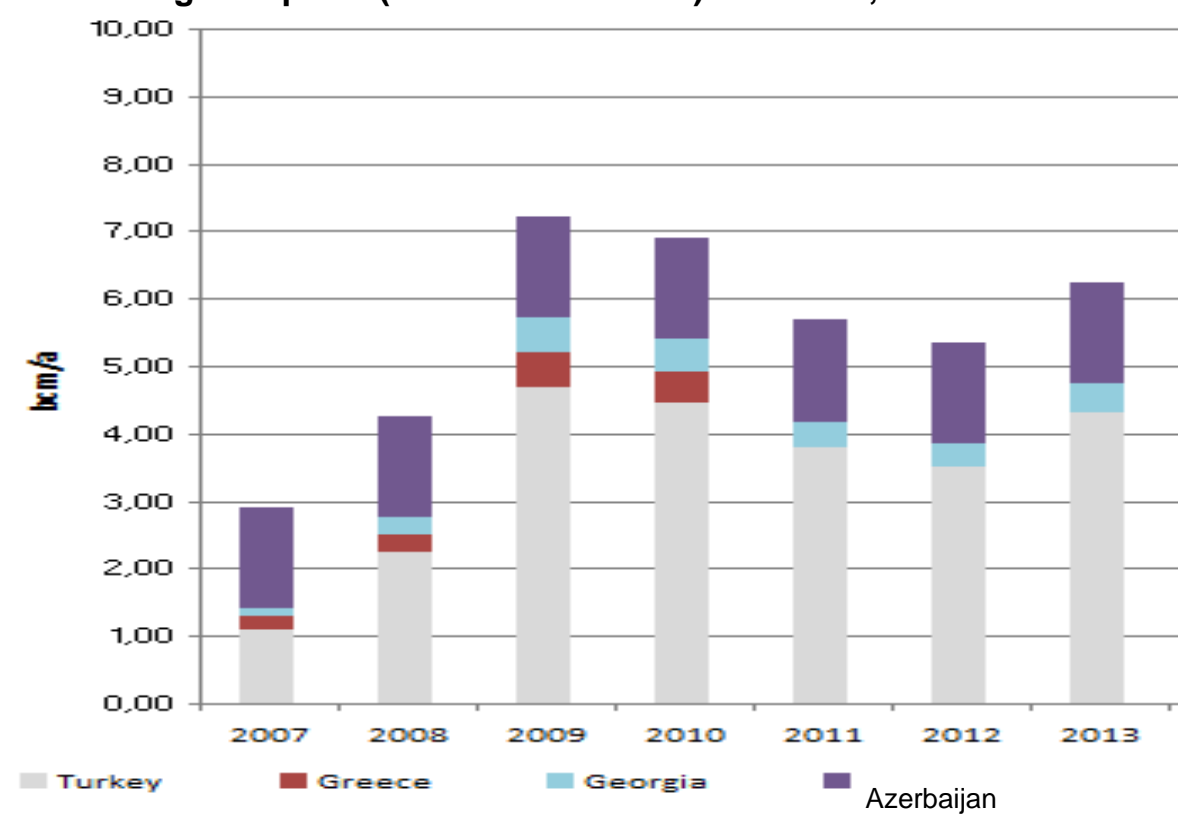

Source: Author's analysis and public domain

Two contracts to supply gas to Georgia were signed by the SD consortium and Georgian Oil \& Gas Corporation (GOGC) in 2001, expiring in 2021-2022, for volumes totaling $0.8 \mathrm{bcm} / \mathrm{a}$ (Figure 7):

- SD and GOGC gas supply contract with a discounted price ( 0.3 bcm/a), and

- SCP including gas as transit fee $(\sim 0.4 \mathrm{bcm} / \mathrm{a})$;

The SD consortium pays Georgia the transit fee for transportation of gas through Georgian territory to Turkey, in the form of delivered gas. Apart from the contracted volume of $0.3 \mathrm{bcm} / \mathrm{a}$, the gas delivered

\footnotetext{
28 "Azerbaijan i Siriya dostigli predvaritelnogo soglasheniya o cene na gas", http://1news.az/economy/oil n gas/20100630121957286.html, 30 June 2010

${ }^{29}$ Jordan Seeks to Import Oil and Gas From Azerbaijan", http://www.bloomberg.com/news/2011-04-13/jordan-seeks-to-importoil-and-gas-from-azerbaijan-petra-says.html, 13 April 2011
} 

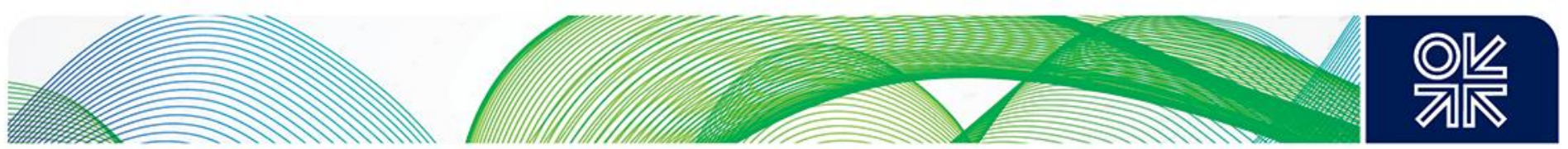

to Georgia as the transit fee ( $5 \%$ of total transit volume) ${ }^{30}$ depends on the gas volume transported through the SCP for Turkey. As described above, Turkey has not been able to offtake the whole contracted volume (of $6.6 \mathrm{bcm} / \mathrm{a}$ ). The actual transit fee therefore very rarely exceeded $0.5 \mathrm{bcm} / \mathrm{a}^{31}$. So far, the total volume of SD1 gas exported to Georgia is $4 \mathrm{bcm}$ and through Georgia $30 \mathrm{bcm}^{32}$.

\section{Non-SD1 Gas export}

In addition to this $0.8 \mathrm{bcm} / \mathrm{a}$ from Shah Deniz, SOCAR has a gas supply commitment of some 0.3-0.4 $\mathrm{bcm} / \mathrm{a}$ to Georgia. SOCAR supplies its own gas to Georgia from the Oil Rocks, Bulla Deniz, Bahar fields etc., via a pipeline linking the two countries in the Gazakh region of Azerbaijan as part of its activity on the Georgian market. The Gazimagomed - Gazakh - Saguramo pipeline, stretches for 416 $\mathrm{km}$ up to the Georgian border $(1020 \mathrm{~mm})$. The pipeline, built in Soviet times, has a capacity of about 3 $\mathrm{bcm} / \mathrm{a}$ that cannot easily be increased. After some rehabilitation in the beginning of 2000s, the pipeline has been used to supply gas to SOCAR's subsidiary SOCAR Georgia Gas ${ }^{33}$ and for peak shaving in the winter season.

Azerbaijan and Georgia signed an agreement in November 2008, providing for SOCAR to undertake trading activity on the Georgian gas market over the five years from 2009. According to the memorandum, SOCAR established a subsidiary, SOCAR Georgia Gas, to implement the project. In total, Georgia imports between 1.1-1.2 bcm of gas from Azerbaijan (Figure 7).

Azerbaijan also agreed to export gas to Greece starting from 2007 via SCP and the BOTAŞ gas transmission system, and expected to supply up to $0.75 \mathrm{bcm} / \mathrm{a}$ to the Greek market ${ }^{34}$. Greece received $0.44 \mathrm{bcm}$ of natural gas from Turkey in 2008 and $0.72 \mathrm{bcm}$ in $2009^{35}$. According to the gas supply agreement from SD1 (gas price review after one year of the gas deliveries to Turkey) and the transit agreement signed by Azerbaijan and Turkey on October $26^{\text {th }}$ 2011, BOTAŞ committed itself to pay the difference between the price before and after the price review, for the gas delivered to Turkey since April $15^{\text {th }}$ 2008. It caused a chain reaction, as DEPA (Greece) had now to compensate BOTAŞ. The amount of the debt arising from natural gas purchases from Turkey was $\$ 300$ million ${ }^{36}$. The payment of the debt had been re-scheduled for 2011 because of the economic crisis in Greece. However due to a number of issues between DEPA and BOTAŞ, the sides failed to reach an agreement and, as a result, deliveries to Greece were terminated in 2010.

In 2010, SOCAR started exporting gas to Russia, based on the contract signed on October $14^{\text {th }} 2009$, via the existing Gazimagomed-Shirvanovka pipeline, with metering stations in Shirvanovka (in Azerbaijan) and in Novo Filya (in Russia). This pipeline is a part of the Gazimagomed-MakhachkalaMozdok pipeline. The medium-term (until 2015) supply contract provides for a minimum offtake volume of $0.5 \mathrm{bcm} / \mathrm{a}$ (Figure 8 ), which can gradually be increased up to $5 \mathrm{bcm} / \mathrm{a}$. The overall length of the pipeline is 680 kilometres, of which 200 kilometres are in Azerbaijan. The pipe diameter is 1,220 $\mathrm{mm}\left(48^{\prime}\right)$ and it had an original capacity of $13 \mathrm{bcm} / \mathrm{a}$. The operating capacity is around $5 \mathrm{bcm} / \mathrm{a}$. In Mozdok, the pipeline is connected with the North Caucasus-Moscow line.

\footnotetext{
30"Infrastruktura dla realizacii proyekta "Energeticheskiy most Azerbaydjan-Gruziya-Turciya" prakticheski gotova”, OilCapital, http://www. oilcapital.ru/industry/252148.html, 12 September 2014

${ }^{31}$ Presentation of T. Gochitashvili made on behalf of GOGC at the Oil and Gas Sector Meeting in Tbilisi, November 2013

32“Total Investment in Shah Deniz Gas Field at \$11.4 Billion”, Natural Gas Europe, http://www.naturalgaseurope.com/shahdeniz-gas-field-investments-profit, 19 November 2014

${ }^{33}$ SOCAR Energy Georgia owns 31 regional gas distribution grids. The average daily consumption of gas by distribution networks operated by SOCAR is 5-6 mcm. In general, these networks consume $60-70 \mathrm{mcm} / \mathrm{a}$. A $\$ 40$ million investment program covers purchase, development and management of distribution networks.

${ }^{34}$ Pirani (2012) OIES

35"Greece may reach agreement with Turkey in natural gas dispute", Today's Zaman, http://www.todayszaman.com/business greece-may-reach-agreement-with-turkey-in-natural-gas-dispute 257519.html, 21 September 2011

${ }^{36}$ ibid
} 

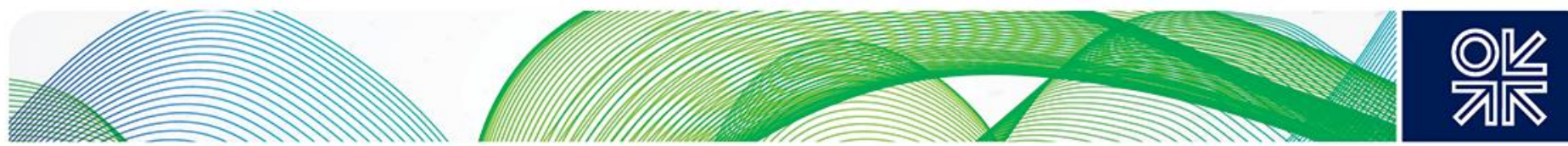

Figure 8: Gas contracted for export from Azerbaijan, 2010-2030 (excludes SD2 exports)

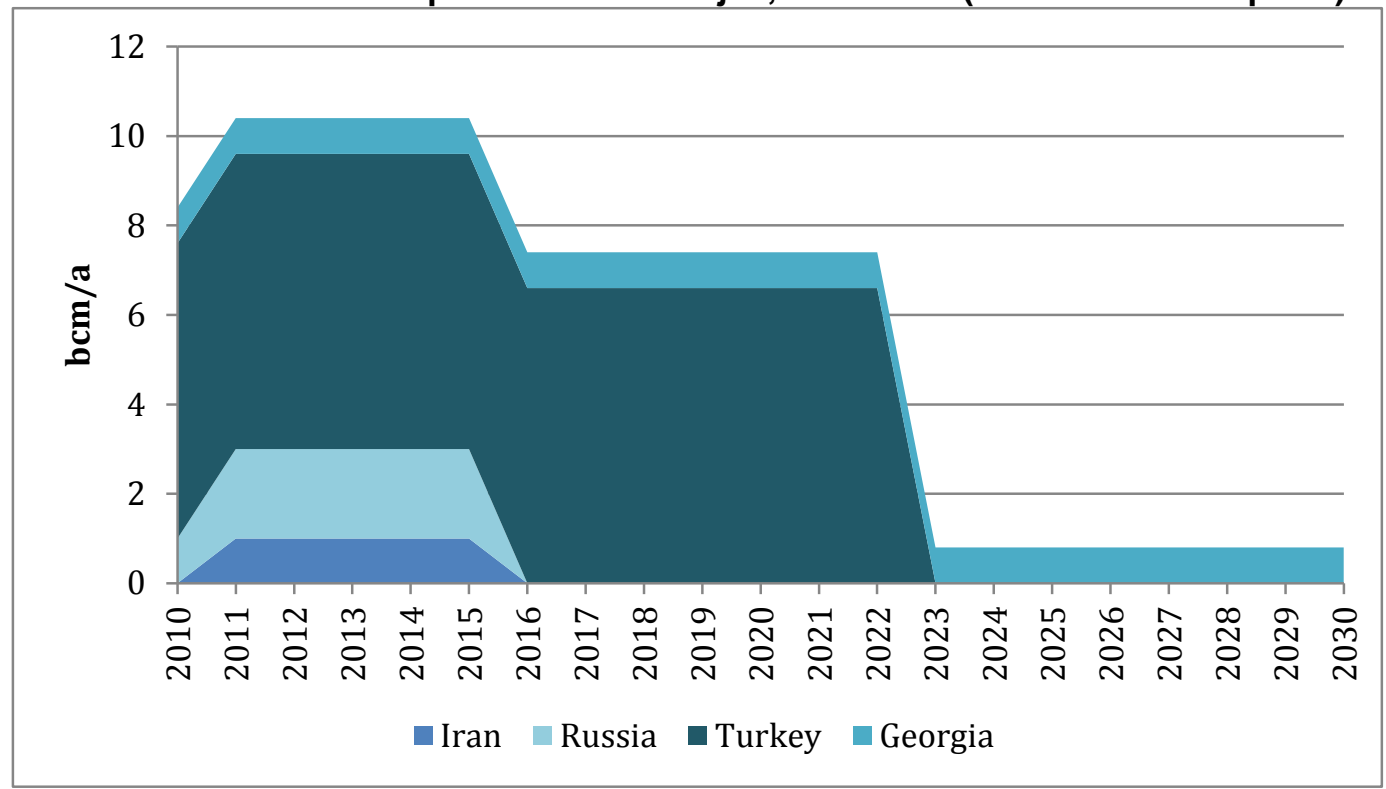

Source: Author, publicly available figures

Note: The gas to Iran is shown in this graph because those volumes are regarded as swaps for imports into the Nakhchivan Autonomous Republic.

Also, due to a supplement to the contract added in 2010, Gazprom was to receive $2 \mathrm{bcm}$ of gas in 2011 and more than $2 \mathrm{bcm}$ in 2012 from SOCAR. The additional agreement to double the volume of Azerbaijani gas purchased by Russia, from $1.5 \mathrm{bcm}$ to $3 \mathrm{bcm}$, was signed by both sides in Sochi on January 24, 2012. However, SOCAR exported only $1 \mathrm{bcm}$ in 2012, $1.37 \mathrm{bcm}$ in $2013^{37}$ and $207 \mathrm{mcm}$ in $2014^{38}$, mainly due to lower demand. Due to decreased gas consumption in Europe, Gazprom redirected certain volumes from its gas portfolio to the Northern Caucasus, to which the Azerbaijani natural gas was contractually destined. If the parties do not notify each other within 6 months of the termination of the contract, it is to be prolonged automatically.

Additionally, SOCAR has a swap contract with Iran to supply the Nakhchivan Autonomous Republic (NAR) (Map 2) up to $1 \mathrm{bcm} / \mathrm{a}$. This is necessary as the Nakhchivan enclave of Azerbaijan has no land border with the main territory of Azerbaijan and borders Iran, Turkey and Armenia. Given the hostilities and Armenian occupation of $20 \%$ of Azerbaijani soil, there is no direct connection between NAR and the rest of the country. Thus, the natural gas flow is being provided via Iran.

\footnotetext{
37“Azerbaijan to resume gas export to Russia soon”, Azernews, http://www.azernews.az/oil and gas/67664.html, 3 June 2014

${ }^{38}$ Rossiya budet pokupat azerbaydjanskiy gaz, nesmotra na otkaz ot sredneaziatskogo, Trend, http://www.trend.az/business/energy/2362548.html, 10 February 2015
} 

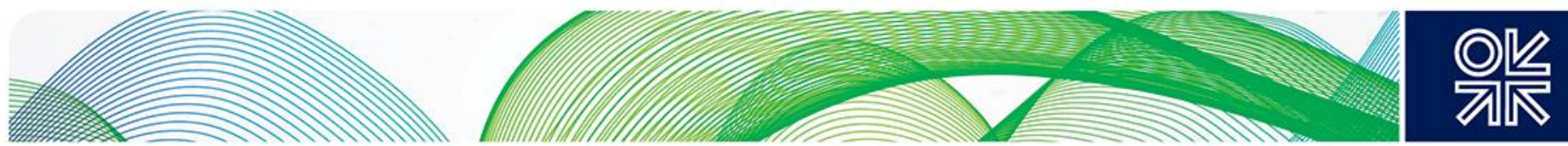

\section{Map 2: Nakhchivan Autonomous Republic}

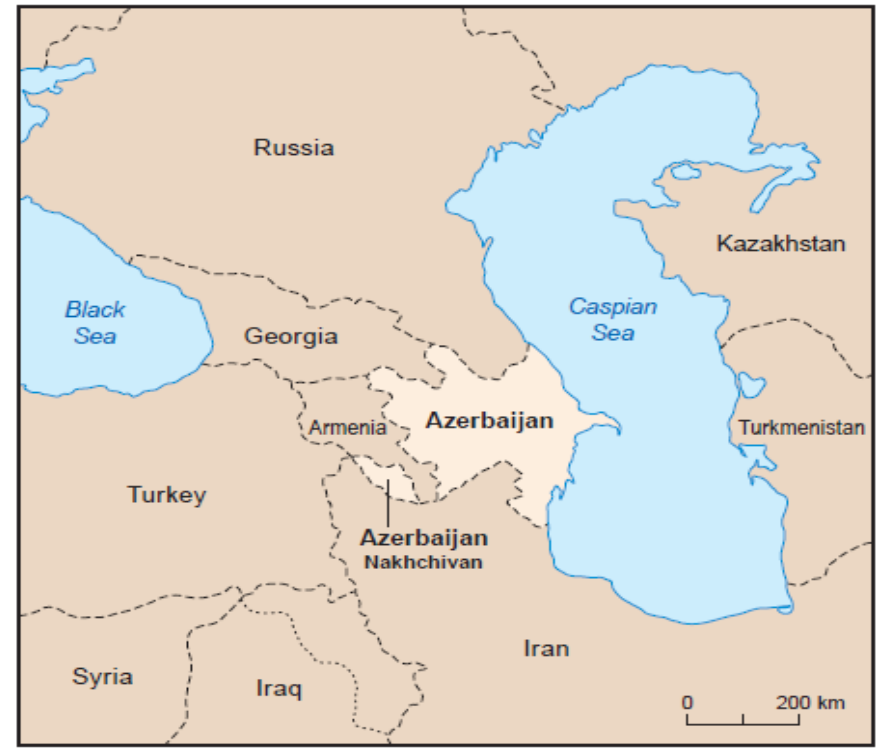

Source: OIES

The contract for the gas trade between Iran and Azerbaijan was signed in 2005. Under the 25-year contract, ${ }^{39}$ Iran receives Azerbaijani gas in Astara (Iran) and transports it to the NAR. In 2013, Azerbaijan transported $424 \mathrm{mcm}$ of gas through the territory of Iran to Nakhchivan AR. For that service, Iran charges $15 \%$ of the value of the offtake as a transit fee ${ }^{40}$, which is quite high compared to the regional average. ${ }^{41}$

\subsection{Shah Deniz Phase 2}

Azerbaijan's gas production will significantly increase from late 2018 with the SD2 start up. This will add some $17.6 \mathrm{bcm} / \mathrm{a}^{42}$ to the $9 \mathrm{bcm} / \mathrm{a}$ produced from the Stage 1, thus increasing overall gas production from the whole SD field to $26.6 \mathrm{bcm} / \mathrm{a}$.

The development of Shah Deniz Phase 2 started on December 132007 when a new high pressure reservoir in a deeper structure of the SD field was discovered. In the beginning of 2010, the $5^{\text {th }}$ appraisal well drilled as part of Stage 2 field development showed the probability of an estimated additional $200 \mathrm{bcm}$ of gas in the deeper structure of the field. Within the Phase 2 field development, two new platforms are to be built and 27 new wells to be drilled (Figure 9).

\footnotetext{
${ }^{39}$ Pirani (2012), OIES

40 Jalilvand (2013), OIES

41"Azerbaijan to increase gas supply through Iran", Trend.az, http://en.trend.az/capital/energy/2302125.html, 12 August 2014

${ }^{42}$ The gas volume available at the Georgian-Turkish border for export will be $17.6 \mathrm{bcm}$ of which $1 \mathrm{bcm}$ is envisaged for the transit fee for Georgia ( $5 \%$ of total export. Total export: $8+16=24 \mathrm{bcm}$. $5 \%$ of $24 \mathrm{bcm}$ is $1 \mathrm{bcm}$ of transit fee).
} 

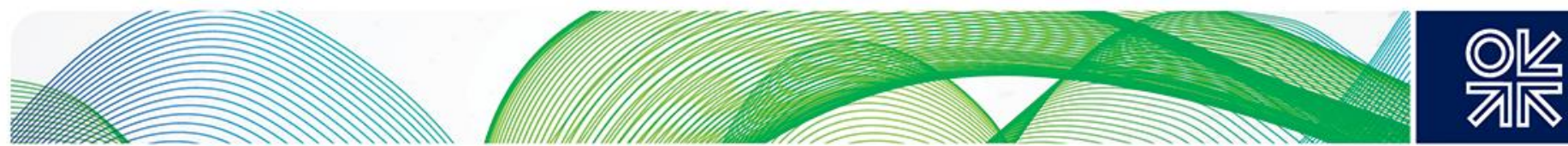

Figure 9: Shah Deniz Phase 2 - Conceptual overview

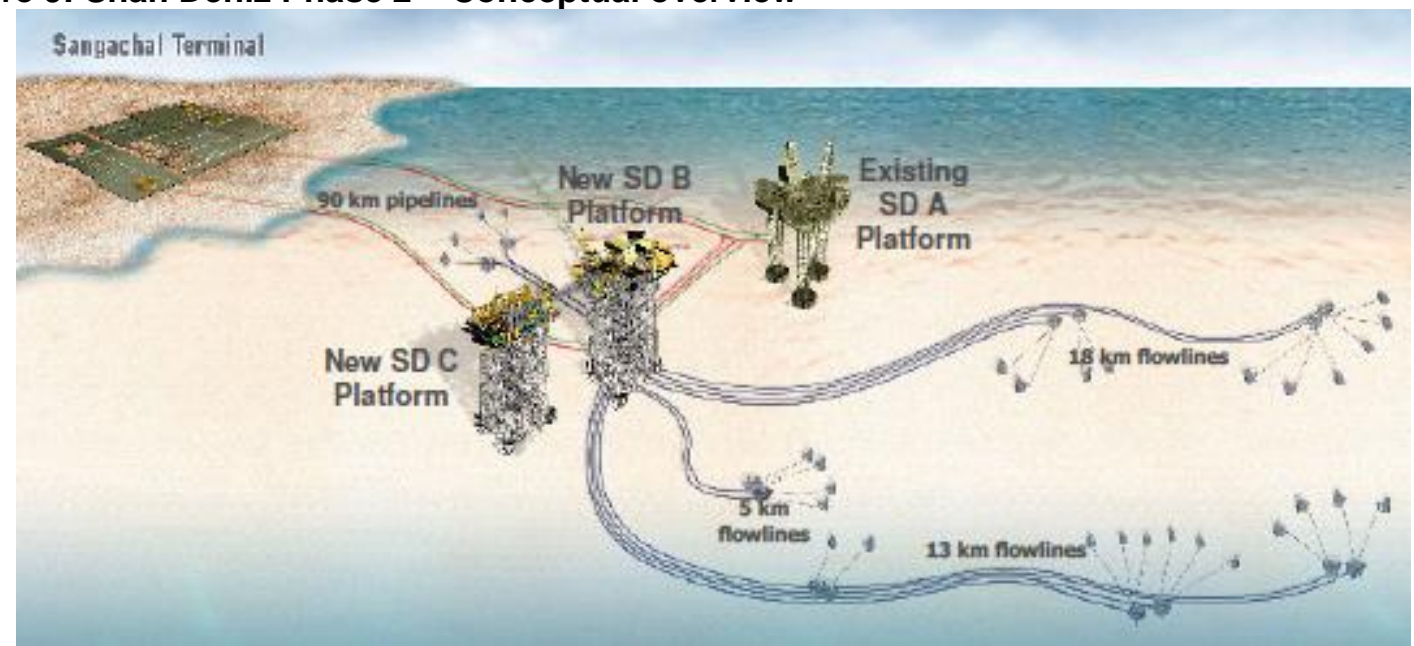

Source: BP

The Shah Deniz Stage 2 Gas Project comprises upstream development both offshore and at the Sangachal Terminal; an expansion of the South Caucasus Pipeline (SCPx) across Azerbaijan and Georgia and onto Turkey; and the export and marketing of the Shah Deniz gas to buyers principally in Turkey and the EU.

Figure 10: Shah Deniz Phase 2 gas production volumes, 2018-2036 (bcm/a) Shah Deniz Phase 2 production volumes: 2018 -2036

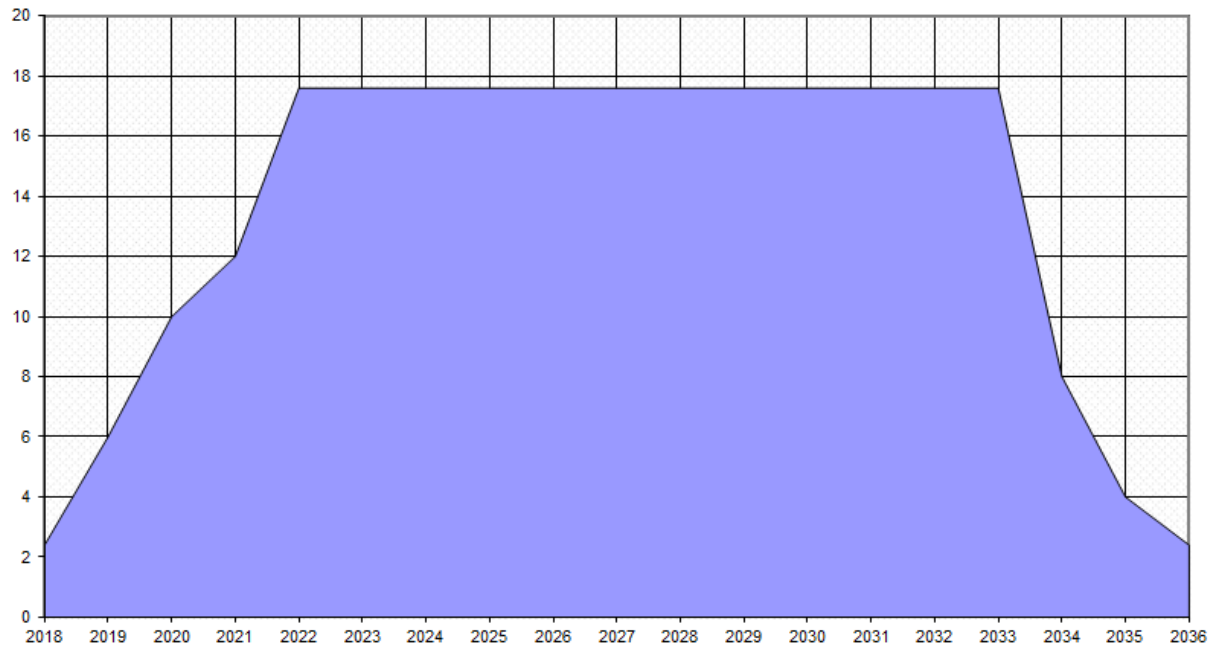

Source: Author's estimate

Plans are in place for a new standalone pipeline to transit Turkey - the Trans Anatolian Natural Gas Pipeline (TANAP), and a further new pipeline from the Turkish western border to Italy - the Trans Adriatic Pipeline (TAP). There, TAP will be connected to the Italian national transmission network, whose owner is Snam Rete Gas. The total estimated cost of SD2 (including Sangachal terminal expansion) and an expansion of SCPx will be around $\$ 28$ billion ${ }^{43}$. Investments for both the TANAP and TAP projects may constitute more than $\$ 17-19$ billion. All these segments, as well as gas

\footnotetext{
${ }^{43}$ BP Press Release, 17 December 2013, "Shah Deniz Final Investment Decision Paves Way for Southern Corridor Gas Link with Europe", http://www.bp.com/en/global/corporate/press/press-releases/shah-deniz-final-investment-decision-pavesway.html
} 

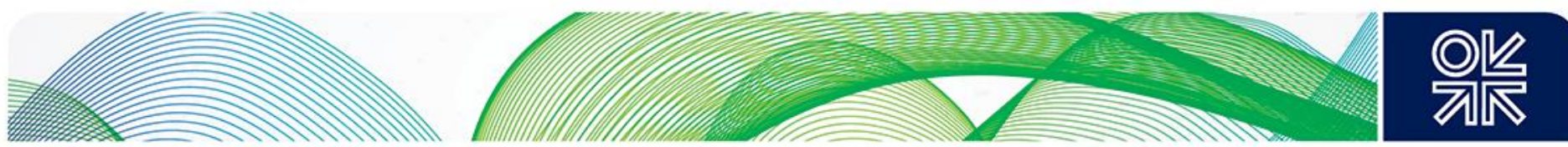

transmission infrastructure to Bulgaria to establish the new Southern Gas Corridor to Europe, will cost an estimated total of $\$ 48$ billion $^{44}$. This includes $\$ 6$ billion for further field development, including the drilling of 26 wells ( 6 wells have been drilled already) and $\$ 15$ billion for the expansion of the offshore facilities, including drilling rigs and other plant and equipment. Expansion of the Sangachal Oil\&Gas Terminal will cost another $\$ 2$ billion ${ }^{45}$.

Despite the discovery of the new high pressure reservoir in a deeper structure of the SD field in 2007, the final investment decision (FID) was long-delayed for a number of reasons. It was finally signed on December $17^{\text {th }} 2013$ in Baku. From a commercial point of view, the comprehensive decision regarding all the segments or sections along the value chain was necessary. The absence of the necessary infrastructure to transport this gas and the market to sell the commodity would undermine the project viability for partners and gas buyers.

The main reasons for the delay in progressing the SD2 development were:

- Lengthy gas sales negotiations, with both Turkish and European buyers,

- establishing acceptable transit agreements between the project partners and Turkey, and

- finalizing a technical cooperation agreement with BOTAS signed on October $26^{\text {th }} 2011$ to accompany a new intergovernmental agreement between Azerbaijan and Turkey.

The SD2 investment decision ultimately hinged on whether TAP or an alternative proposed pipeline to Central Europe, Nabucco West, would be developed as an EU export outlet. The delay in SD2 field development resulted in the SD partners extending the SD PSA for a further 5 years, from 2031 to 2036 on November $11^{\text {th }} 2010^{46}$ in accordance with the provisions in the existing PSA. Subsequently, on December 172013 the PSA was prolonged till $2048^{47}$ to allow for further exploration work relating to Phase 3 (See Section 6).

The Exploration Development and Production Sharing Agreement (EDPSA) granted by the Republic of Azerbaijan to the Agreement Parties gave the right to explore for and produce hydrocarbons from the Shah Deniz prospective block in the Caspian. The key provisions of the EDPSA include:

- The definition of the Shah Deniz exploration area

- the investment and work commitment scope

- the application of the taxation principles,

- the involvement of the State in decision-making,

- the costs which may be recovered by the Contractor Parties against petroleum production, and

- the profit sharing formula.

The SD EDPSA also allows for cost recovery of the gas marketing activity (all costs of transportation to the point of sale and of marketing, including pipeline tariffs, commissions and brokerages) reflecting the importance for the Caspian gas of an evacuation route to market. The original EDPSA was dated June $4^{\text {th }} 1996$.

\footnotetext{
44“Investments in Southern Gas Corridor to reach $\$ 48$ billion”, Azernews, http://www.azernews.az/oil and gas/74373.html, 8 December 2014

${ }^{45}$ SOCAR representative presentation made at the Malta Energy Conference on 10-11 July 2014

${ }^{46}$ Project timeline, BP's official webpage, http://www.bp.com/en az/caspian/operationsprojects/Shahdeniz/projecthistory.html

47 “Azeri SOCAR and consortium extend Shah Deniz agreement to 2048”, Reuters, 17 December 2013, http://uk.reuters.com/article/2013/12/17/azerbaiian-gas-investment-idUKL6NOJW1CJ20131217
} 

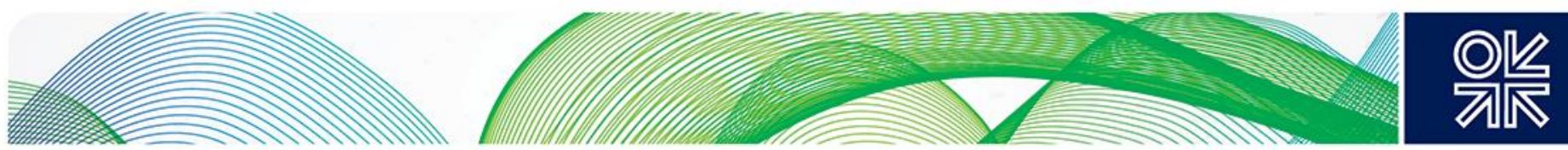

The Shah Deniz field operation is still led by BP which has a share of $28.8 \%$. Other partners include TPAO (19\%), SOCAR (16.7\%), Petronas of Malaysia (15.5\%) (acquired Statoil's share in November $2014)^{48}$, LukOil (10\%) and NIOC (10\%). Eni sold its 5\% share to LukOil in June 2004. Later divestitures included the sale, prior to SD2 FID in December 2013, of 10\% by Statoil to BP and SOCAR (who acquired 3.3\% and 6.7\% respectively ${ }^{49}$ ); the sale by Total SA in May 2014 of its $10 \%$ share to Turkish TPAO; 50 and Statoil's sale of its $15.5 \%$ to Petronas (Figure 11). Statoil reported the sales price for its share as $\$ 1.45$ billion $^{51}$. Although, the sales price of Total shares to TPAO was not disclosed, analysts estimate it to be comparable to Statoil's price.

\section{Figure 11: Equity Ownership across the Southern Gas Corridor}

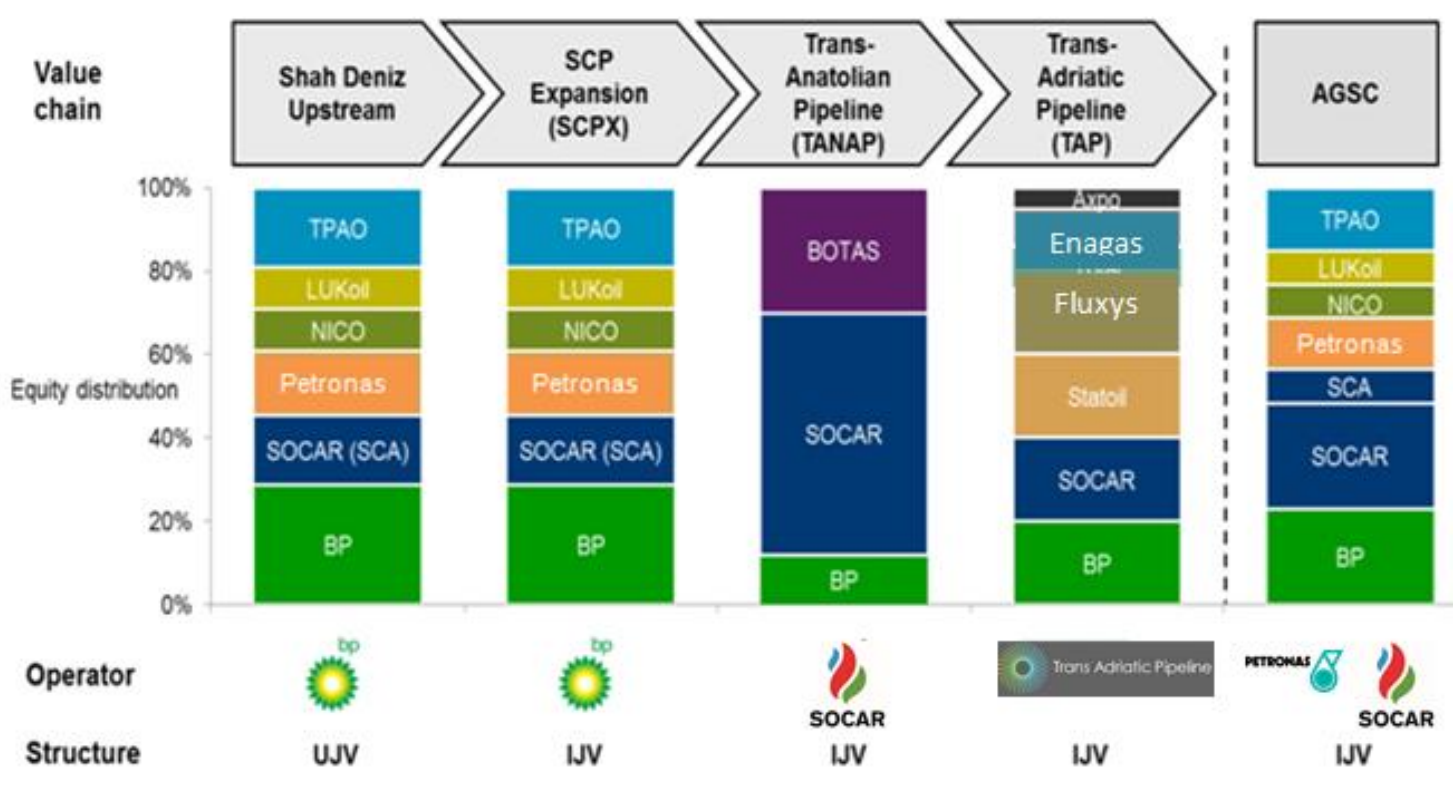

Source: SOCAR, BP. Modified in accordance with changes by the author

Note: IJV: Incorporated Joint Venture; UJV: Unincorporated Joint Venture, SCA: SOCAR Company Affiliates

\subsubsection{South Caucasus Pipeline Expansion}

The gas from Stage 1 of the Shah Deniz contract area is transported in the South Caucasus Pipeline (SCP) and delivered to buyers in Azerbaijan, Georgia and Turkey. SCP is owned by the South Caucasus Pipeline Company Limited (SCPC) which is a separate legal entity. Stage 2 of the SD project includes an expansion of SCP. SCP runs for approximately $690 \mathrm{~km}$ from its Entry Point at the Sangachal Terminal in Azerbaijan across Georgia to the eastern Turkey border (Figure 12).

\footnotetext{
48"Statoil exits Shah Deniz gas project with stake sale to Petronas", Reuters, http://www.reuters.com/article/2014/10/13/usstatoil-petronas-shahdeniz-idUSKCN0I209020141013, 13 October 2014

49 "Statoil's farm down in Shah Deniz and South Caucasus Pipeline completed",

http://www.statoil.com/en/NewsAndMedia/News/2014/Pages/06May ShahDeniz.aspx, 7 May 2014

50 "Total Sells \$1.5 Billion Azeri Gas-Project Stake to Turkey", Bloomberg, http://www.bloomberg.com/news/2014-05-29/turkeyto-increase-stake-in-azerbaijan-s-shah-deniz-gas-project.html, 30 May 2014

51 "Total to sell its stake in Azeri Shah Deniz gas field", Reuters,

http://uk.reuters.com/article/2014/02/28/gas-azerbaijan-total-idUKL6NOLX2U820140228, 28 February 2014
} 

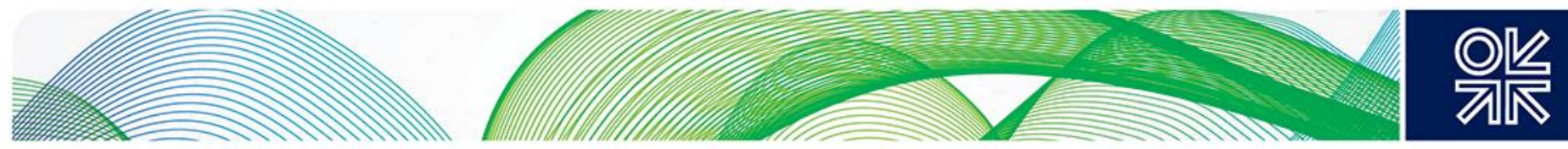

Figure 12: South Caucasus Pipeline Expansion

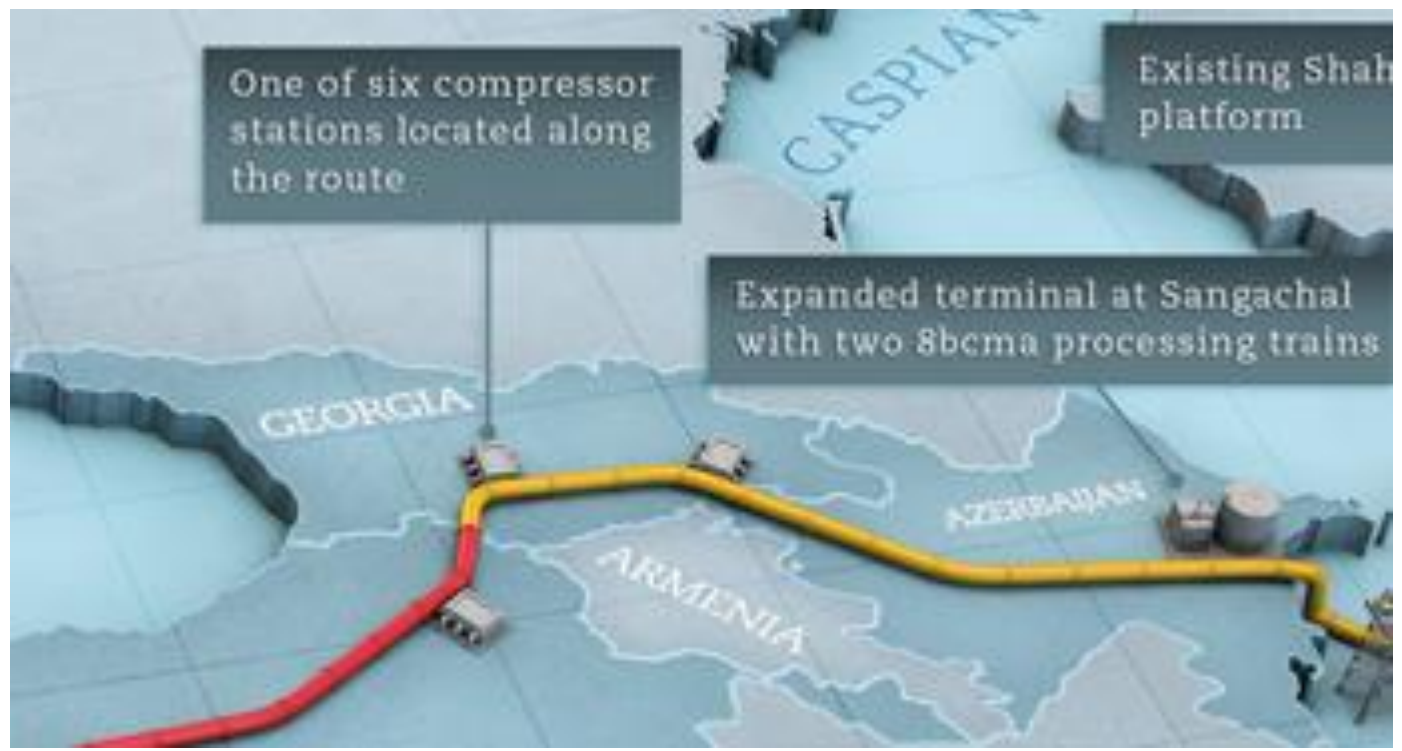

Source: Offshore Energy Today, 2014

There are multiple exits or Redelivery Points as follows:

a) Azerbaijan Low Pressure Redelivery Point;

b) Azerbaijan High Pressure Redelivery Point;

c) Azerbaijan/Georgia Redelivery Point;

d) Georgia/Turkey Redelivery Point (at the interconnection with the BOTAŞ network);

e) TANAP Redelivery Point (at the interconnection with TANAP) (to be constructed as part of the SCP expansion).

AGSC (Azerbaijan Gas Supply Company) and SOCAR as two shippers have executed Gas Transportation Agreements (GTAs) for transportation services in SCP. The SCP-AGSC Consolidated GTA was amended and restated on December 172013 to extend and expand its scope to include not only the transportation of Stage 1 volumes but also Stage 2 volumes ${ }^{52}$.

The SCP Expansion was supported by a number of agreements signed by the partners on December $182012^{53}$.

At the moment, SCP's throughput capacity is up to $8 \mathrm{bcm} / \mathrm{a}$. After the expansion, the whole export system on the territory of Azerbaijan and Georgia (SCP and SCPX) will have the capacity to transport contracted export commitments from the both SD1 and SD2 volumes up to $26 \mathrm{bcm} / \mathrm{a}$ in total. From the total $17 \mathrm{bcm} / \mathrm{a}$ volumes of SD2 up to $11 \mathrm{bcm} / \mathrm{a}$ will be delivered to Europe and up to $6 \mathrm{bcm} / \mathrm{a}$ will be delivered to Turkey. BP will remain the technical operator of SCPX, whereas SOCAR will be able to play a key role in decisions on how big the future capacity of SCPX will be, when it should be expanded and so on. Such decisions however will inevitably be determined by the pace and scale of commercially viable future field developments in Azerbaijan. Moreover, SOCAR's decisions can only be implemented if its partners in the various pipeline segments agree to provide investment funding for the proposed expansions. Furthermore, any decision driven by SOCAR to expand export

\footnotetext{
${ }^{52}$ South Caucasus pipeline, http://www.bp.com/en az/caspian/operationsprojects/pipelines/SCP.html

53 "The New Agreement between BP Azerbaijan and South Caucasus Pipeline", Contact.az,

http://www.contact.az/docs/2013/Economics\&Finance/012300025666en.htm\#.VB V BZ8qM4, 23 January 2013
} 

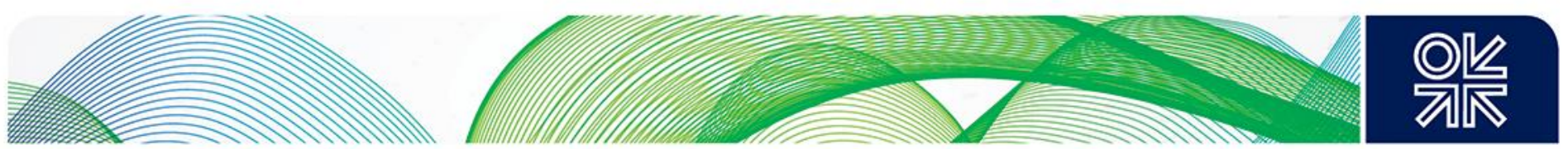

infrastructure would be dependent on a commitment from an upstrem field development group to accept the tariff terms for such expansion.

\subsubsection{Trans-Anatolian Pipeline (TANAP)}

Before TANAP was initiated, lengthy negotiations on transit of SD2 gas through Turkish territory between the Azerbaijani and Turkish governments, and SOCAR and BOTAŞ, were completed, and all the terms and conditions agreed.

The gas transit negotiations between the two countries started in 2009 and took two years. They were fraught with political and commercial difficulties. The Turkish-Armenian détente in 2010 had a negative influence on the negotiations and made them even more complex. From the commercial point of view, the transit fee, the gas price paid by BOTAŞ, and other terms and conditions took some while to conclude through negotiation. The European Union and the United States urged both sides to complete the negotiations in a timely manner.

The Turkish-Azerbaijani transit agreement was designed to set out the specific duties and obligations of the Turkish side in transiting the SD2 gas up to the Turkish/European border via the BOTAŞ transmission system. Once this was signed, the companies developing the Shah Deniz gas and condensate field would have a clear set of arrangements that would enable them to sell their gas under fully defined commercial conditions. The agreement was signed in 2011, once all the terms and conditions on transiting SD gas via BOTAŞ system had been agreed.

A major issue in anticipating the need for increased transport capacity through Turkey was the evident constraints in the existing BOTAŞ transmission system, which at times has been insufficient to cope with its own domestic requirements, let alone SD2 and potential additional flows of transit gas from future Azerbaijan field developments.

The solution was the creation of a standalone dedicated pipeline, which would be regulated by an Inter-Governmental Agreement, but operated on the basis of terms and conditions agreed and arranged in the consortium contract. In 2011 Azerbaijan announced the TANAP Project that would replace the Turkish infrastructure.

TANAP is being developed by an independent project company TANAP Doğalgaz Iletim A.Ş. ("TANAP A.Ş.") in which the shareholders are SOCAR, BOTAŞ and BP. The agreements which govern transportation of SD gas across Turkey include (at governmental level) the TANAP Host Government Agreement, and (at the commercial level), the TANAP/SD2 Gas Transit Agreement (SD2 GTA). Other shippers will each have their own GTA for transportation services in TANAP.

The SD consortium, through its gas sales vehicle AGSC, will be an Initial Shipper in TANAP (for 10.9 $\mathrm{bcm} / \mathrm{a}$ at plateau), as will BOTAŞ (6 bcm/a) and SOCAR. The total capacity in the pipeline will be around $31 \mathrm{bcm} / \mathrm{a}$. The project lifetime is deemed to be 49 years. The TANAP final investment decision is expected to be made in summer 2015.

BOTAŞ is also entering into a GTA with TANAP. The TANAP/BOTAŞ GTA is required to be on substantially similar terms as the TANAP/AGSC GTA, except that it is for 15 years ${ }^{54}$ from a Start Date before the end of June 2018 and for a capacity of $6 \mathrm{bcm} / \mathrm{a}$ intended to align with the BOTAŞ SD2 Gas Sales Agreement. According to a report of the Turkish Parliament on the approval of the amendment on exemption of VAT of the Host Government Agreement (HGA), signed by the Republic of

\footnotetext{
${ }^{54}$ Türkiye Büyük Millet Meclisi, Yasama Dönemi 24, Yasama Yılı 4, Sıra Sayısı 646, Türkiye Cumhuriyeti Hükümeti ile Azerbaycan Cumhuriyeti Hükümeti Arasında Trans Anadolu Doğal Gaz Boru Hattı Sistemine İlişkin Hükümetlerarası Anlaşmanın Eki Türkiye Cumhuriyeti Hükümeti ve The TransAnatolian Gas Pipeline Company B. V. Arasında Trans-Anadolu Doğal Gaz Boru Hattı Sistemi Hakkında Ev Sahibi Hükümet Anlaşmasına İlişkin Değişikliğin Onaylanmasının Uygun Bulunduğuna Dair Kanun Tasarısı ve Dışişleri Komisyonu Raporu (1/947), http://www.tbmm.gov.tr/sirasayi/donem24/yil01/ss642.pdf
} 

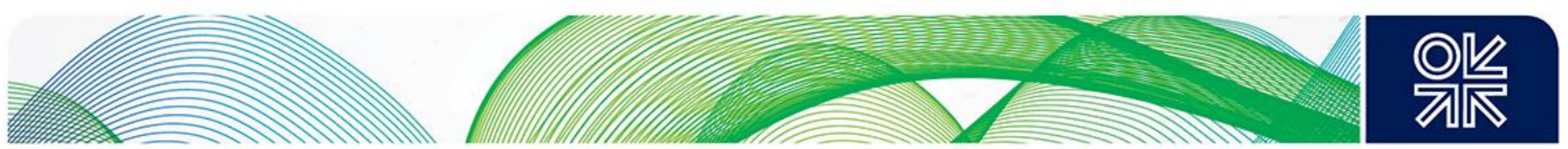

Azerbaijan and the Republic of Turkey, the transportation tariff for BOTAŞ in accordance with the GTA is approved as $\$ 79 / 1,000$ cubic metres $/ 100 \mathrm{~km}$. BOTAŞ will offtake its gas in Eskişehir. For other companies the GTA at the Trakya offtake point is approved as $\$ 103 / 1,000$ cubic metres ${ }^{55}$.

Developing and operating the pipeline together with the partner companies would be convenient for SOCAR in terms of sharing technical and financial risks and burden.

Participating in projects such as TANAP could give companies additional strategic advantages, of transporting their gas to be extracted, for example, for Total from the Absheron field; for BP from the Shafarg-Asiman; for Statoil from the Zafar-Mashal fields and prospective blocks in the future. It also allows them to be a part of the entire value chain.

SOCAR with a $58 \%$ share wanted to have majority decision making rights. This may be the reason why the partners did not join TANAP; alternatively they may have assumed that their return on investment from participating in the pipeline was insufficiently attractive, especially given that it was clear that other partners would fund the project without their involvement. At the moment the shareholding stands as the following: SOCAR $-58 \%$, BOTAŞ $-30 \%$ and BP $-12 \%$.

\section{Gas supplies to Turkey}

The accords on the Gas Transport Agreement (GTA) (TANAP-SD2) between SOCAR and Botaş were signed on May 30th 2014. The project economics were supported by both the $6 \mathrm{bcm} / \mathrm{a}$ of gas for the Turkish market and additional volumes destined for Europe. Moreover, TPAO increased its share of the SD2 project from $9 \%$ to $19 \%$, acquiring Total's $10 \%$ stake, paying $\$ 1.45$ billion $^{56}$. Two different Turkish state companies, BOTAŞ and TPAO, along with BP and SOCAR will have a stake both in the upstream and midstream segments of the project.

\subsubsection{Selection of the market}

SD2 is a part of the Southern Energy Corridor (SGC) project, which has been initiated by the European Union. Its aim is to diversify the sources of energy supply, particularly for countries that are almost entirely reliant on one supplier. The European Commission initiated the SGC in 2009, in the aftermath of the gas price disputes of 2006 and 2009 between Ukraine and Russia, to encourage alternatives to Russian gas supplies from the Caspian Sea and Middle East regions into Europe. After these gas crises, the EU, US and Turkey sharpened their focus on Azerbaijan to enhance engagement and import complementary amount of gas from Caspian sources.

The SGC may develop into a significant new supply route that can facilitate the transport of gas from different sources, not only from Azerbaijan, but also Central Asia and Iraq. As and when such opportunities arise, SGC can expand its capacity to link new field developments to markets (the infrastructure to be built through Turkey is scalable to $30+\mathrm{bcm} / \mathrm{a}$ ).

In the period prior to the 2008-09 financial crises, the energy demand of European consumers was at its peak. It was projected (e.g. by the IEA and CERA) that this trend would only move upwards. This situation made all energy supply sources, especially those in the Caspian region, crucial for consumers in the EU, which was worried about its energy security in general and uninterruptible gas supplies in particular. Military conflict in Ukraine on the EU's Eastern border has since raised even greater concerns about the interruptability of gas supplies and the price of energy.

\footnotetext{
${ }^{55}$ ibid

56 “Turkey expects $\$ 27.8$ bln gross in Shah Deniz project", Daily Sabah, http://www.dailysabah.com/energy/2014/06/02/turkeyexpects-278-bln-gross-in-shah-deniz-project, 2 June 2014
} 

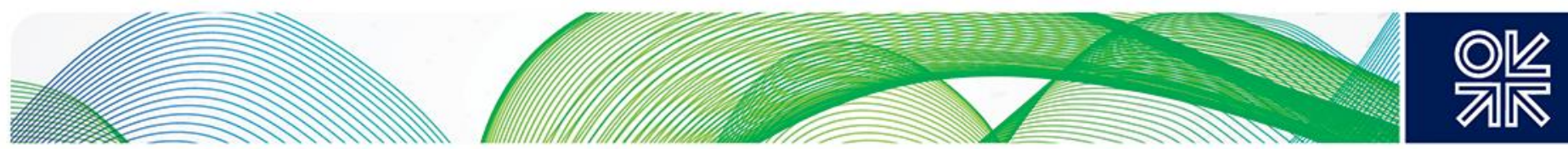

The EU is encouraging projects to bring additional volumes of gas from new sources via alternative routes. According to the Commission Staff Working Document published in July 2014, the total capacity of pipelines directed to the EU from supplier countries is $397 \mathrm{bcm} / \mathrm{a}$. The major entry points of the pipelines are on the eastern borders of the EU and in the north. Azerbaijan will supply $10 \mathrm{bcm} / \mathrm{a}$ of gas starting from late $2019 / 2020$ but volumes could increase significantly beyond 2020 facilitated by infrastructure expansion. ${ }^{57}$

For Azerbaijan, as a natural gas producing country, access to the open, transparent and liberalised European gas market, and expanding and developing new export routes, were and remain priority issues in its energy strategy. The preferred route of the SGC was determined to give access to the Italian Market by way of Turkey.

\subsubsection{Trans-Adriatic pipeline}

The markets for Azerbaijani gas in Europe were selected at the end of June 2013. The decision was made in favor of TAP, which links gas exports to Southern Italy by way of Greece and Albania (Map 3). This pipeline is designed for future expansion from 10 to $20 \mathrm{bcm} / \mathrm{a}$ and in some sections to have built-in physical reverse flow, connecting directly with various existing and proposed pipelines providing energy security in Southeastern Europe ${ }^{58}$. It is designed also to provide Bulgaria with a new source of gas, through the Interconnector Greece-Bulgaria (IGB) or Kula-Sidirokastro Interconnector.

\section{Map 3: Trans Adriatic Pipeline and the Ionian Adriatic Pipeline (IAP)}

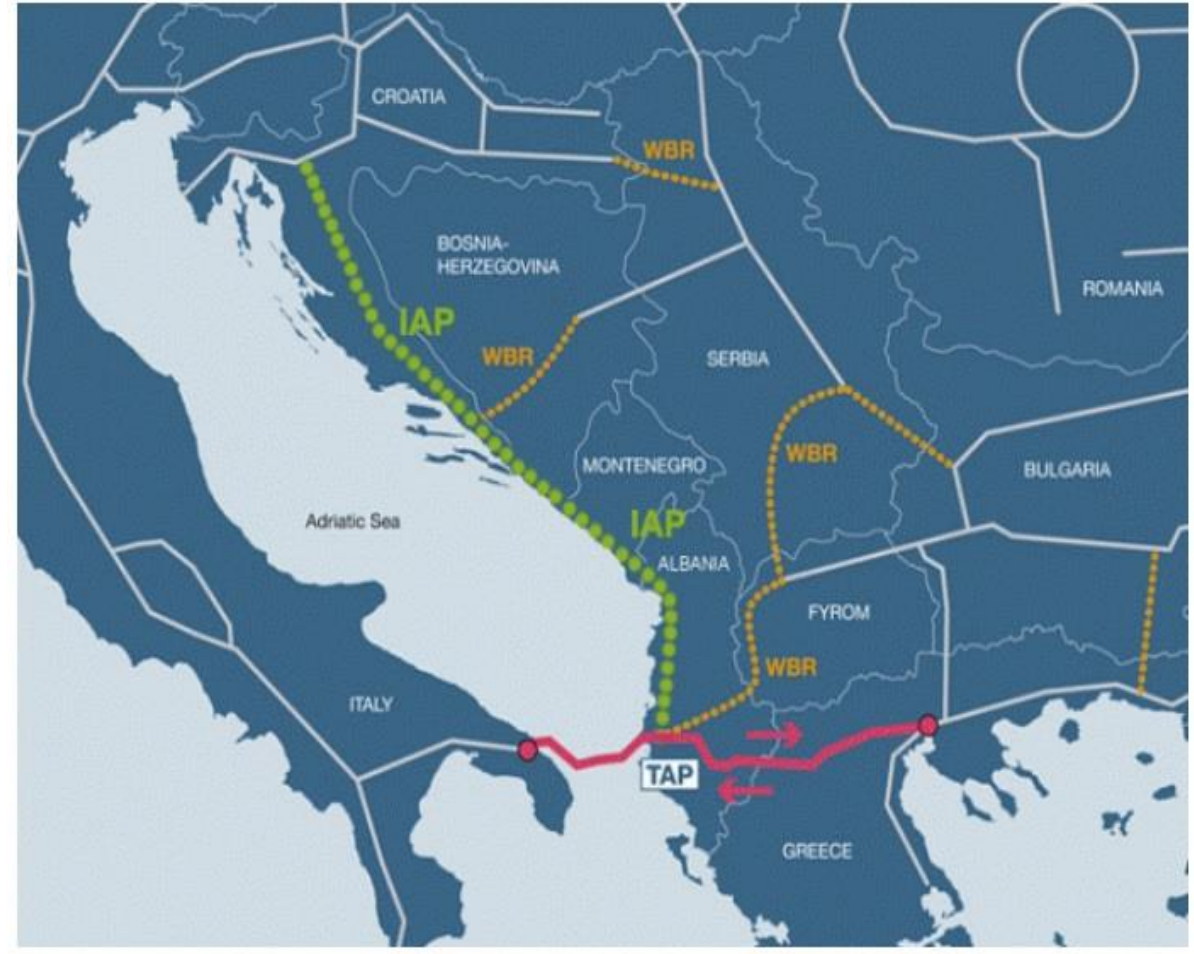

Source: TAP

\footnotetext{
${ }^{57}$ COMMISSION STAFF WORKING DOCUMENT. In depth study of European Energy Security, Accompanying the document Communication from the Commission to the Council and the European Parliament: European energy security strategy; $\{\mathrm{COM}(2014) 330$ final\}; Brussels, 2.7.2014, SWD (2014) 330 final/3

${ }^{58}$ TAP official web page, http://www.tap-ag.com/
} 

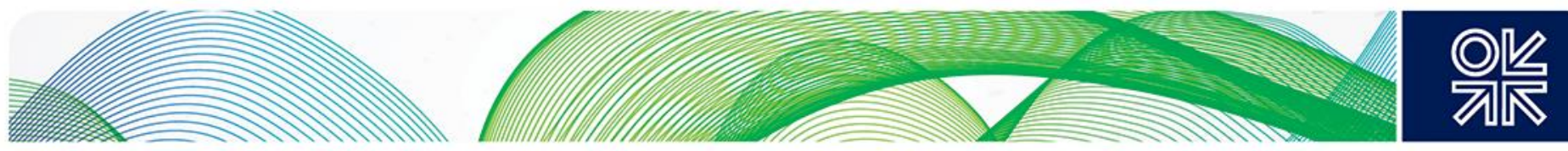

The market selection process lasted nearly 10 years; starting from 2003 when the Nabucco project was first announced. Competition between TAP and Nabucco West during the last 4-5 years has progressed in accordance with the EU rules and requirements. The viability of both projects was of utmost importance for the SD partners among other criteria, and the decision was mainly driven by commerciality requirements.

The negotiations with potential buyers started in January 2010. One of the defining factors was the price. The gas price in the South East European (SEE) market as well as at the Austrian Baumgartner hub was $9-10 \%$ lower than the gas price in Italy and the Italian PSV hub (and remains so), although our assumption is that this will not last for much longer. As shown in Figure 13, the gas price at the PSV hub was the highest, almost 35 euro/MWh in 2012, when the negotiations with the potential buyers were ongoing, whereas at the Central European Gas Hub (CEGH), formerly known as Gas Hub Baumgartner it was around 27 euro/MWh in the same year.

Figure 13: European gas hubs price correlation: 2007-2014

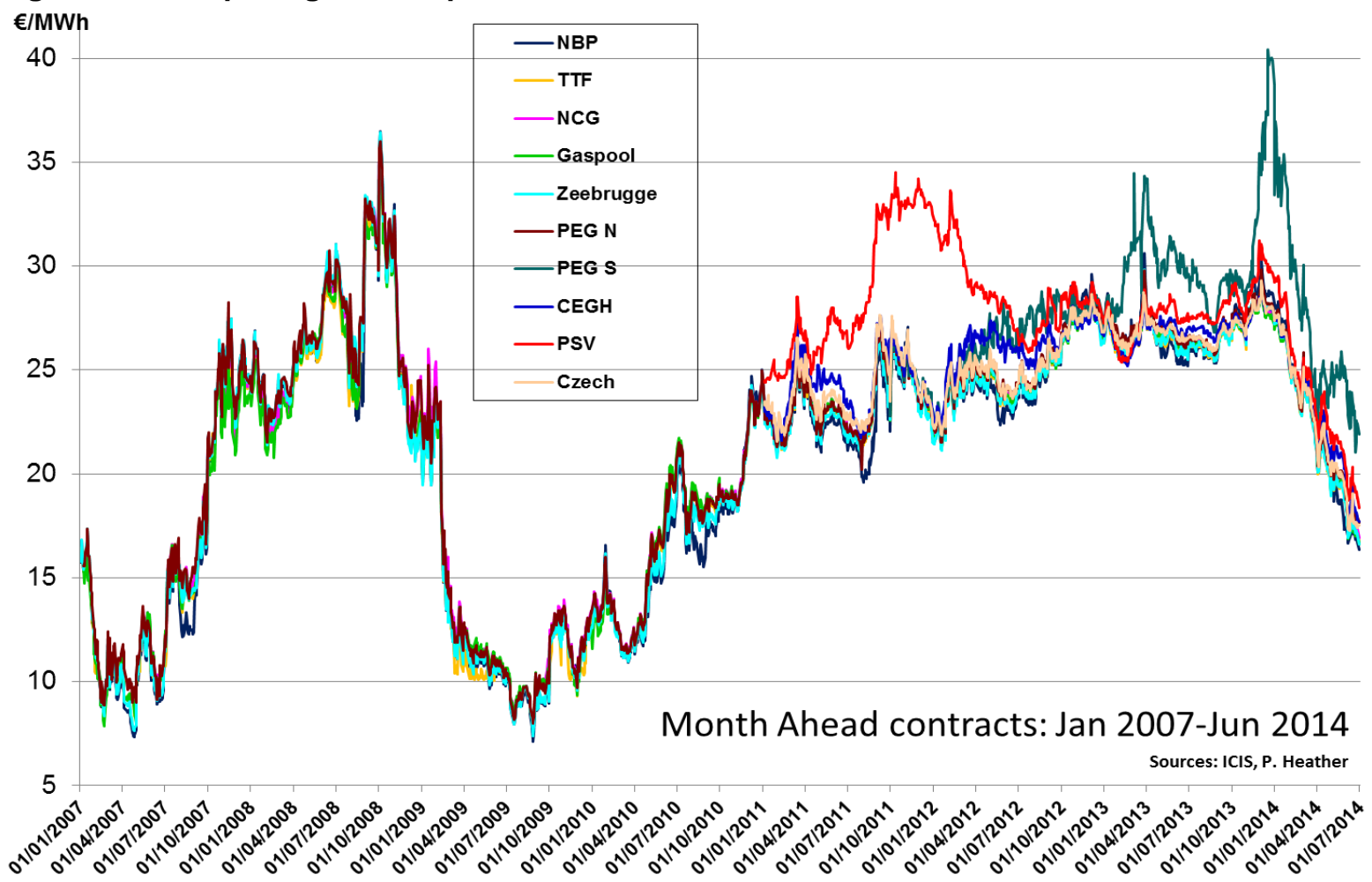

Source: OIES, ICIS, P. Heather

It should not be forgotten that the gas price was affected by concessions given by Gazprom to its European customers amidst a rising sense of urgency among new and existing gas exporters to maintain market share ${ }^{59}$.

Despite the fact that the demand in the Italian market is at best stagnant and according to IEA projections will remain so until 2020, the partners contracted SD2 gas for Europe through the TAP pipeline. It turned out that the Italian natural gas market is better positioned to absorb the majority of the additional $8 \mathrm{bcm} / \mathrm{a}$ in 2020, than the SEE market.

Decisions were made by the IOCs and SOCAR based on the calculation of the investments in the entire value chain, which constitute more than $\$ 48$ billion, vis-a-vis market variables such as demand

\footnotetext{
59“'Bulgaria obtained a 22\% discount, Romania 5\%, Hungary 2\% and Austria 11\%. See The Southern Gas Corridor: Who Stands Where?", Rzayeva (2014), Natural Gas Europe
} 

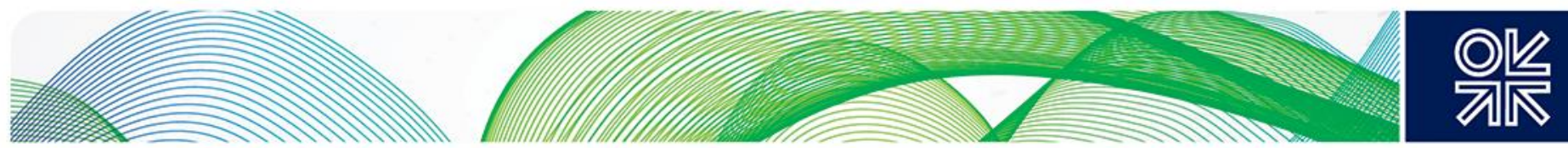

security, competitiveness, price and price formation mechanism and opportunity to access nearby markets. This makes a difference to the netback margin of the companies that are investing and developing the upstream and midstream projects (between the two markets).

Furthermore, TAP offers opportunities to the gas sellers to freely ship gas to neighboring countries. Italy is best positioned to transit gas sourced in Azerbaijan to adjacent markets via the existing infrastructures (Map 4). Also, TAP will connect to the Italian natural gas grid to provide firm capacity at the Italian virtual trading point (PSV), from which all the Italian gas exit points can be reached. This is in line with the Italian National Investment Strategy plan to turn Italy into a transit country and Southern Europe's gas trading hub by $2020^{60}$. Within this policy, in 2012 Italian gas transmission system operator Snam Rete Gas published its Gas Regional Investment Plan for the "Southern Corridor" region for 2012-2021. This report includes mid- and long-term plans to strengthen national networks and increase market integration by enhancing cross-border bi-directorial flows of existing interconnectors ${ }^{61}$.

Gas delivered via TAP can reach Austria via the TAG pipeline, Germany via TENP, Switzerland and France via Transitgas ${ }^{62}$ (Map 4). All of these pipelines have almost similar transportation capacity and a modest investment in reverse technical capacity will be needed. The TENP pipeline has $25 \mathrm{bcm} / \mathrm{a}$ average swap potential (2011). Transitgas - Virtual backhaul of approx. $10 \mathrm{bcm} / \mathrm{a}$ planned physical backhaul is $15 \mathrm{bcm} / \mathrm{a}$ of.

\section{Map 4: Interconnectors between Italy and adjacent markets}

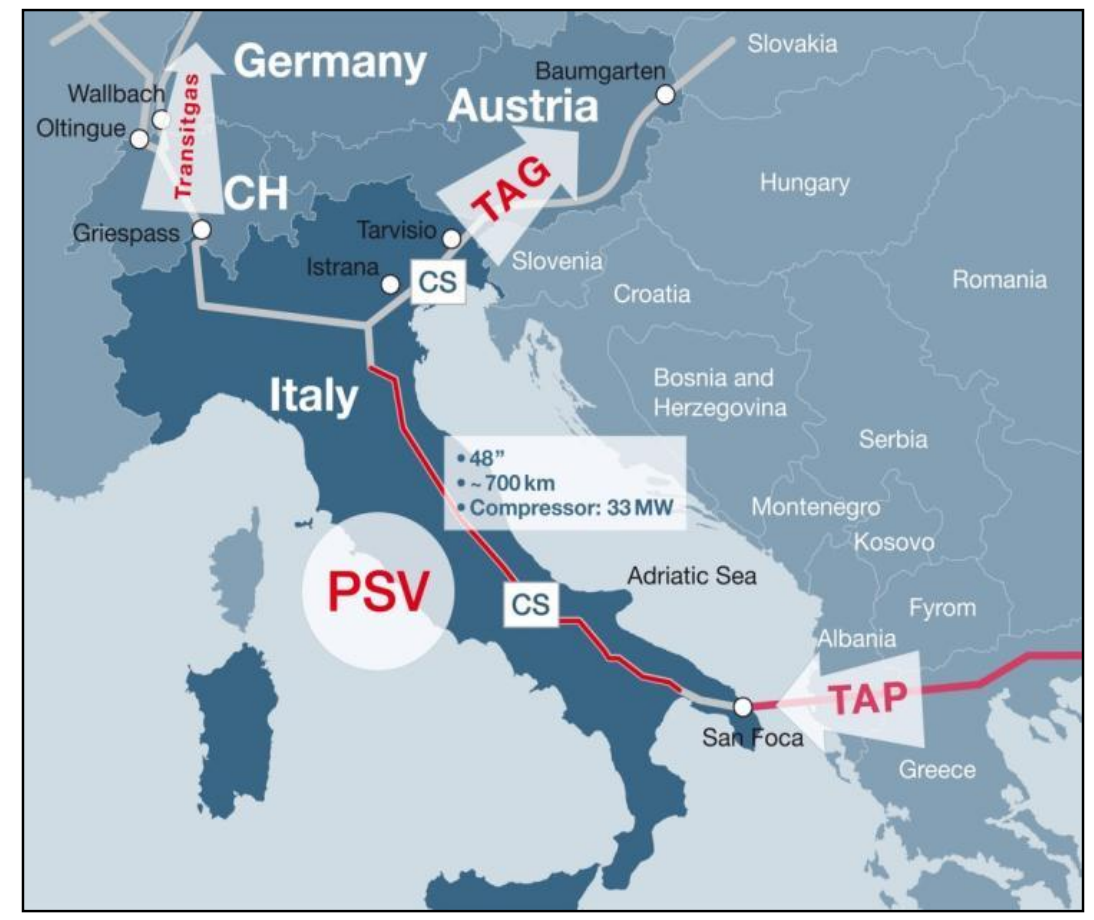

Source: TAP

\footnotetext{
${ }^{60}$ Italy's National Energy Strategy,

http://www.encharter.org/fileadmin/user upload/Energy policies and legislation/ltaly 2013 National Energy Strategy ENG.p df, March 2013

${ }^{61}$ Gas Regional Investment Plan (GRIP) for "Southern Corridor" region for 2012-2020, http://www.snamretegas.it/export/sites/snamretegas/repository/attivita/scenario/GRIP SNC.pdf See also: Gas Regional Investment Plan for the "South-North" for 2012-2021

62 Honore (2014), OIES
} 

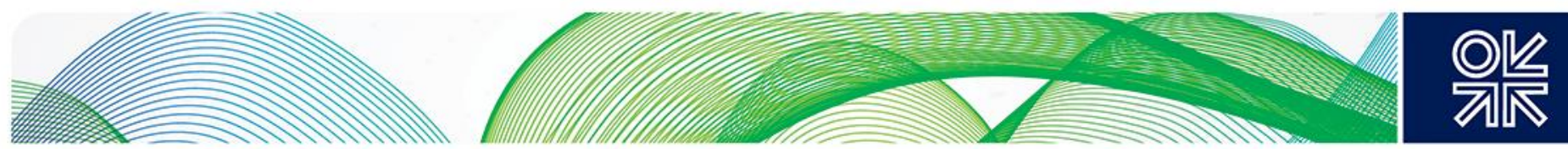

The Balkan market with its growing gas demand and high prices for gas remains within the interest focus of the gas seller companies of the SD consortium. The proposed lonian Adriatic Pipeline, although not a part of the TAP pipeline, is envisaged to be connected to it (Map 5). IAP will bring the gas to Montenegro, Bosnia and Herzegovina and Croatia. Further, the gas can be delivered to the Central European market via the existing interconnectors as shown in Map 5.

\section{Map 5: IAP and its position within the region of South East Europe}

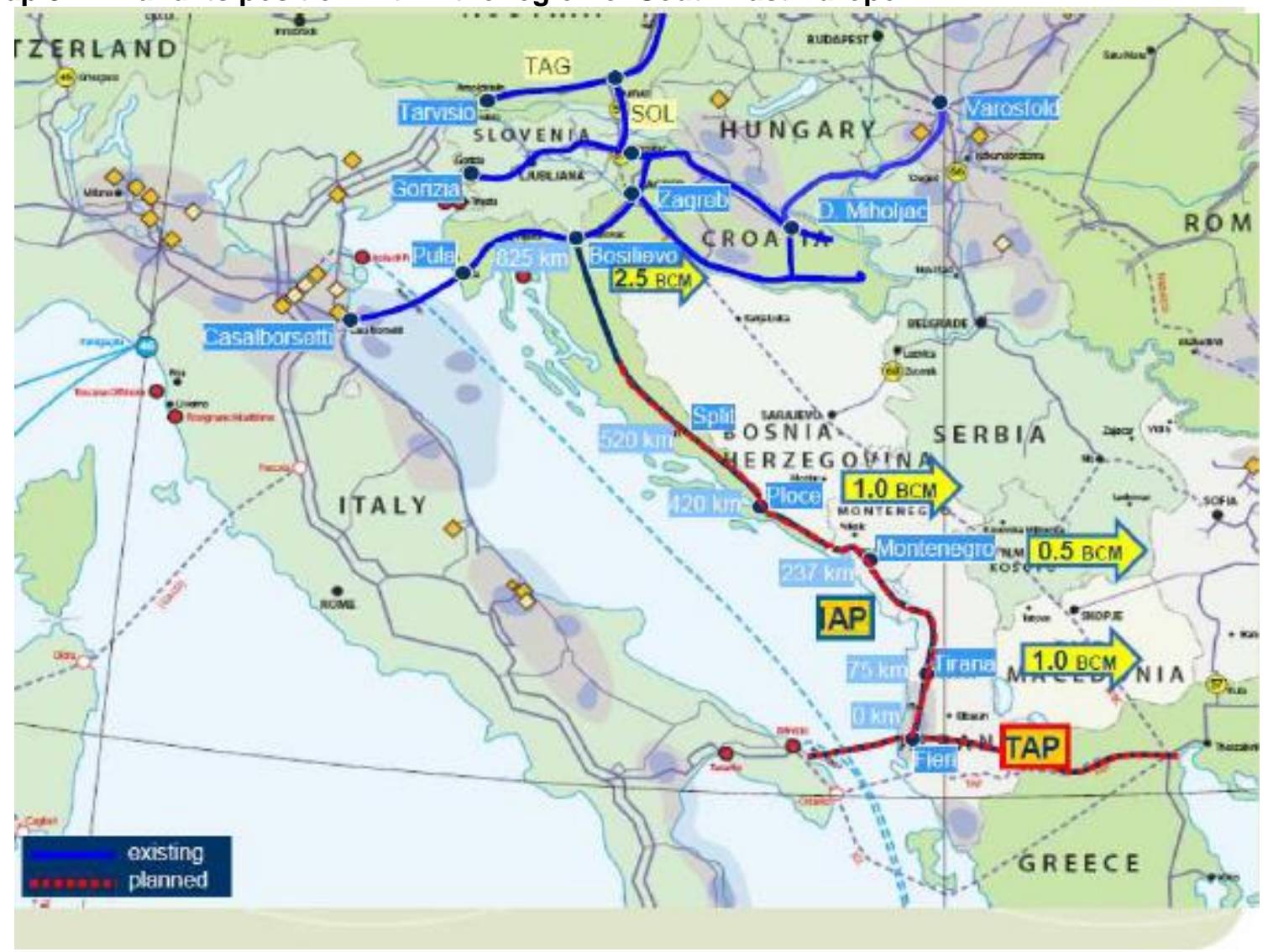

Source: Plinacro

TAP has been granted a third party access exemption for 25 years for $10 \mathrm{bcm} / \mathrm{a}^{63}$ starting from $2020^{64}$, the first of its kind under the $3^{\text {rd }}$ Energy Package of the EU.

\subsubsection{Azerbaijan Gas Supply Company Limited}

The Azerbaijan Gas Supply Company (AGSC) is the downstream sales and marketing company for the SD Project. It was created in 2003 to manage gas allocations, gas sales and gas transportation from SD1 to customers in Azerbaijan, Georgia and Turkey. It is jointly beneficially owned by each of the upstream partners and SOCAR. The largest share belongs to SOCAR, although this is less than $50 \%$ (Figure 11). The reason for the unusual structure is that SOCAR, as the State Representative, has more gas: in addition to its $16.7 \%$ share in the upstream, it also manages the share of PSA 'profit gas' which belongs to the State. Day to day management of operations is currently carried out by

\footnotetext{
${ }^{63}$ Presentation of Clara Poletti, Head of the Department for Regulation AEEGSI, http://www.ispionline.it/it/documents/Workshop06.02.14Presentazione.Poletti.pdf

64 The decision has been made by the EUC to consider starting the year of TAP exemption from 2020 (before it was 2018 ). Brussels, 17.3.2015 C(2015) 1852 final,

https://ec.europa.eu/energy/sites/ener/files/documents/2015 tap prolongation decision en.pdf
} 

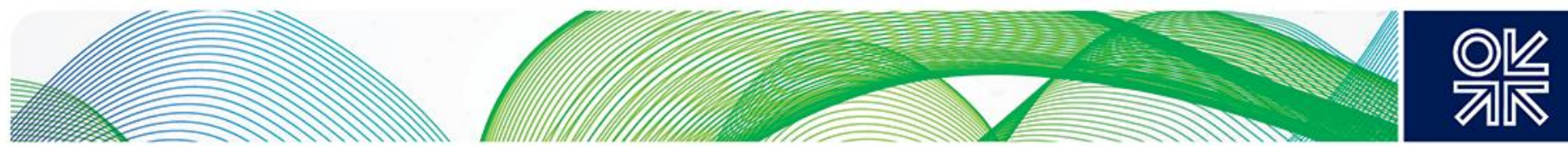

SOCAR as AGSC Operator ${ }^{65}$. SOCAR has replaced Statoil as a commercial operator for the Shah Deniz consortium. The shareholdings of the Contractor Parties in AGSC are not the same as in the SD EDPSA. This is because SOCAR and its affiliate (as State Representative) hold in total a $28 \%$ (20\% SOCAR and $8 \%$ SOCAR Affiliate) interest in AGSC, as shown in Figure 11.

\subsubsection{EU Gas Sales Agreements}

The SD partners, after defining the market for Azerbaijani gas, three months later on September $9^{\text {th }}$ 2013 concluded gas sale agreements with the European buyers. The EU Gas Sales Agreements (EUGSAs) are long-term contracts (LTCs), signed for 25 years with 9 buyers in Italy, Greece and Bulgaria (Map 6). The negotiations started in January 2011.

\section{Map 6: SD2 gas sales geography}

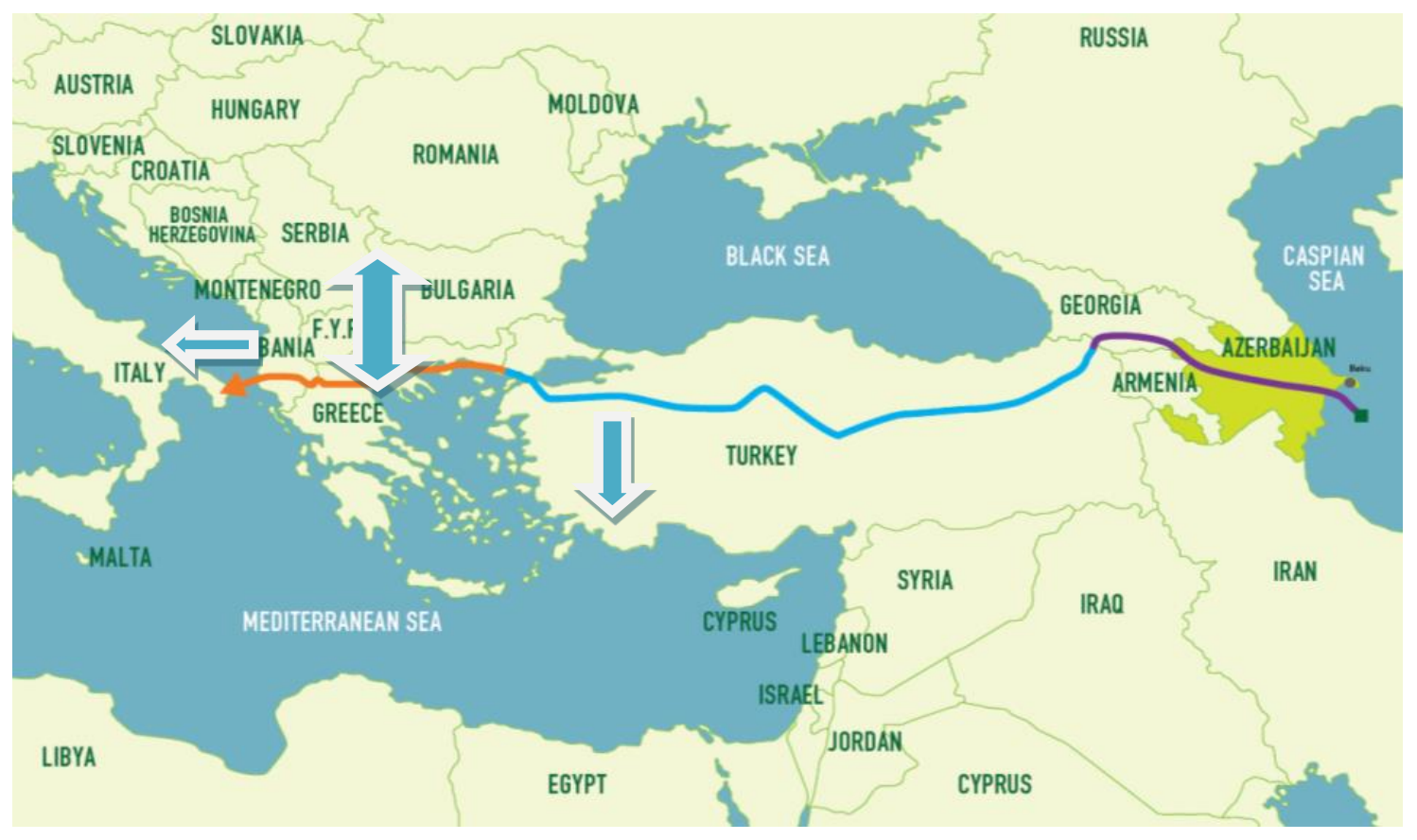

Source: BP

The overall gas volume of SD2 contracted at the Georgia-Turkey border will be above $16 \mathrm{bcm} / \mathrm{a}$, of which about $10 \mathrm{bcm} / \mathrm{a}$ is contracted with the European buyers and $6 \mathrm{bcm} / \mathrm{a}$ with BOTAŞ. $1 \mathrm{bcm} / \mathrm{a}$ will be transferred to Georgia (5\% of $24 \mathrm{bcm} / \mathrm{a}$ of total export) as a transit fee.

AGSC functions as follows: it buys gas from each of the upstream parties (including SOCAR), sells it (principally to BOTAŞ and to European buyers under the EU GSAs) and ships this gas, through the SCP for SD Stage 1, then for Stage 2 - TANAP and finally TAP.

\section{Gas sales to BOTAŞ}

The SD1 agreement was dated March $12^{\text {th }} 2001$ and commenced delivery in late 2006. Deliveries of gas are on-going under the BOTAŞ SD1 GSA with AGSC as the seller. The contractual volume is up 

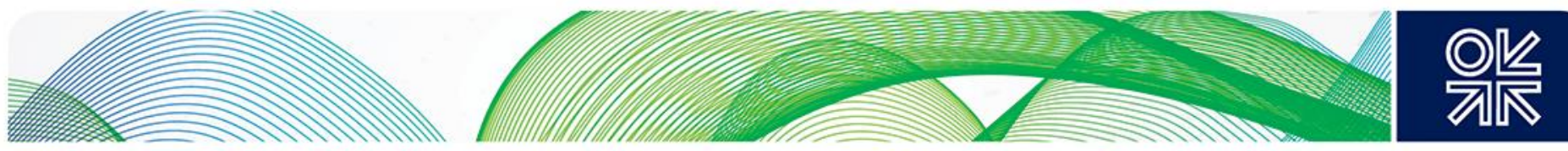

to $6.6 \mathrm{bcm} / \mathrm{a}$ and lasts until December $31^{\text {st }} 2020$ (with $2 \mathrm{bcm}$ to be delivered between January $1^{\text {st }}$ 2021 and April 16 $6^{\text {th }}$ 2021). The gas delivery point is defined as the Georgian/Turkish border.

The BOTAŞ SD2 GSA was entered into by SOCAR and novated to AGSC in 2012 in respect of the sale and purchase of SD2 gas. The plateau volume will be $6 \mathrm{bcm} / \mathrm{a}$. The agreement has a term of 15 years (including the build-up). The delivery point is at the Georgian/Turkish border.

\subsection{Summary}

All the gas available for export from SD Phase 1 and 2 is contracted. The third Phase of the project is envisaged to be appraised and potentially developed in the early 2030s and production from this Phase could feasibly add an additional $10 \mathrm{bcm} / \mathrm{a}$ to the export portfolio. The SD3 project is described in Section 6.

The biggest buyer of SD1 gas is BOTAŞ, under a contract that ends in 2021. Due to the reasons described in this section, it is not known at this stage whether the parties will extend the contract further. The tail off period of SD1 starts from 2030-31 and in the event that the contract is extended, the export of the same volumes to Turkey can technically be continued until the end of the 2020s. The contract might not be extended due to reasons such as the availability of cheaper gas volumes from Kurdistan (which is highly uncertain due to the current political tensions in Iraq), or the increase of contracted volumes from Russia at lower prices. This is possible although it would require Gazprom to provide a significant discount on current contract prices. Turkey would prefer to maintain diversity of supply by taking Azerbaijani gas but clearly there is the potential for competition with Russia, should Russia decide to compete on price. SD 2 contracts with the European buyers have been signed for 25 years with deliveries starting in 2020. The tail off period of SD2 starts in the mid 2030s. The contracts with the EU buyers expire in 2045 (the SD PSA was expanded till 2048). This means that we may assume that the SD partners have the incentive to explore, develop and produce gas from the SD Phase 3 to maintain the gas deliveries to the customers through extension of the GSAs. 

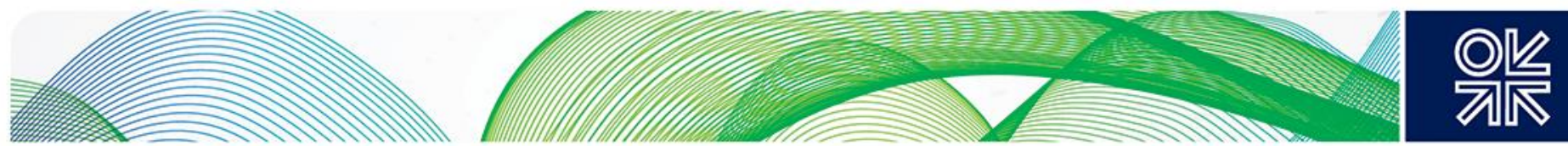

\section{SOCAR gas production portfolio: ACG Associated Gas and Shallow Water Guneshli, Gum Deniz-Bahar/Bahar2 and Bulla Deniz}

This section describes SOCAR's production portfolio, which comprises SOCAR's share of Shah Deniz Phase 1; about $1.5 \mathrm{bcm} / \mathrm{a}$ of associated gas from producing oil fields (ACG and Shallow Water Guneshli); and volumes from mature natural gas fields that have been producing for decades which are now in decline (Gum Deniz-Bahar, Bulla Deniz). These fields are shown in Map 7.

\section{Map 7: Oil and gas fields/blocks in Azerbaijani sector of Caspian Sea}

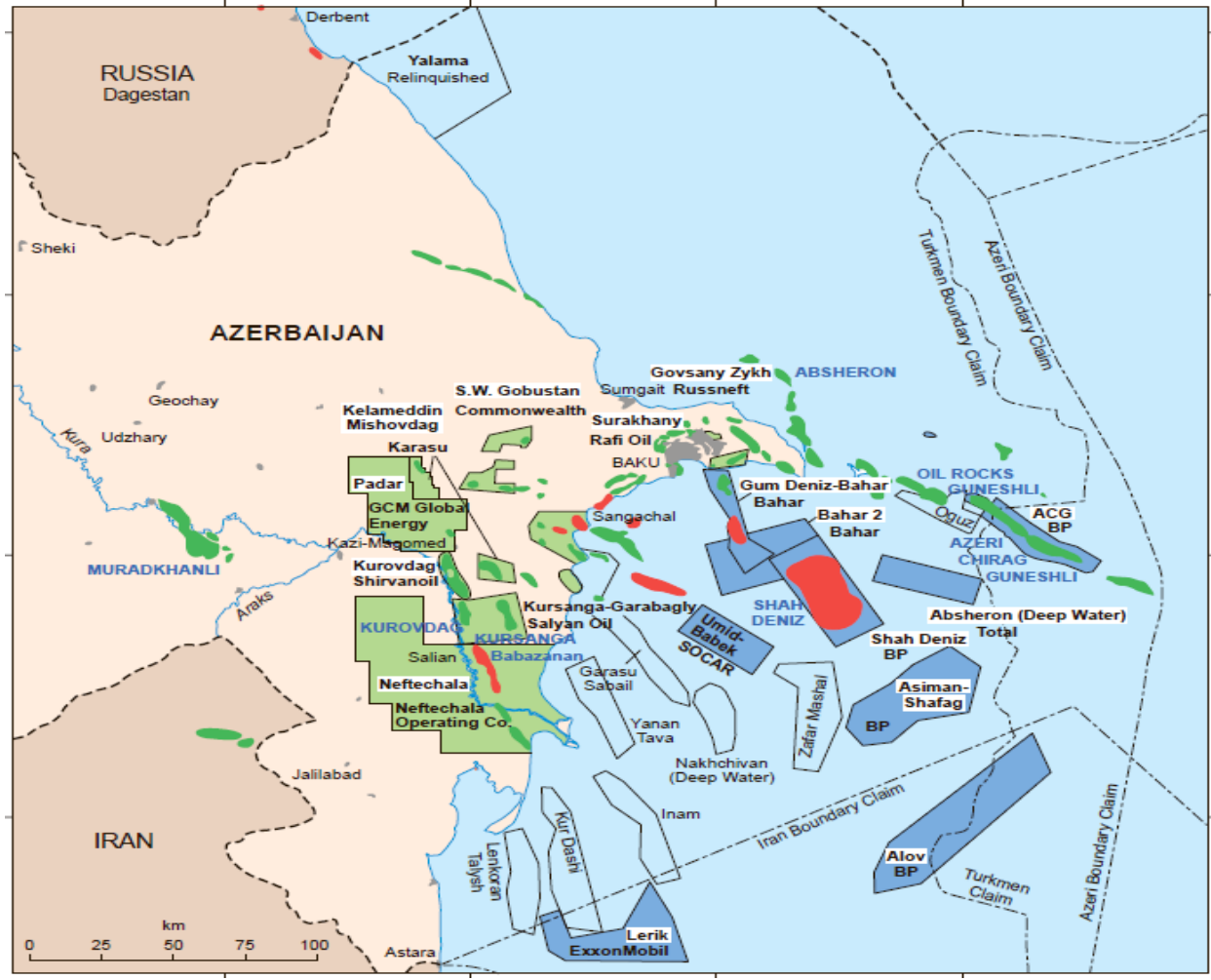

Source: OIES

There are a number of oil fields with substantial associated gas reserves, such as Azeri-ChiragGuneshli and Shallow Water Guneshli. Significant quantities of associated gas are present in other offshore oil fields such as Oil Rocks, although much of this gas is used in operations or re-injected to enhance oil recovery. In addition to SOCAR's own fields, under the terms of the PSA the associated gas produced in the ACG field belongs to SOCAR (being transferred to SOCAR for no fee) and is included in the company's own gas portfolio.

At the time that the Azeri-Chirag-Deepwater Guneshli PSA was negotiated (prior to that of Shah Deniz), the IOCs were primarily concerned with oil. With uncertainties over both the quantity of associated gas production, over the term of the PSA, and the market for natural gas in Azerbaijan and neighboring Caucasus markets, it seemed appropriate to agree to pass any gas production, not required for operations, to SOCAR, which had been supplying the Azerbaijani market for many years. 

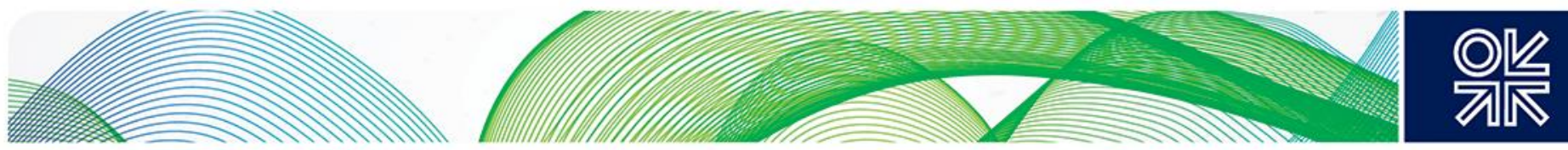

The total annual volume of SOCAR's gas production in 2013 was $7.14 \mathrm{bcm}^{66},{ }^{67}$. Non-SOCAR gas production in Azerbaijan in the same year was $22.3 \mathrm{bcm}^{68}, 80 \%$ of total production (Figure 14, 15). SOCAR uses this gas in the domestic market, where annual demand is around $10 \mathrm{bcm} / \mathrm{a}$ and exports to Georgia around $1 \mathrm{bcma}$, Iran less than $0.5 \mathrm{bcm} / \mathrm{a}$, and has the right to market $1.2 \mathrm{bcm} / \mathrm{a}$ in Turkey.

Figure 14: Gas production in Azerbaijan

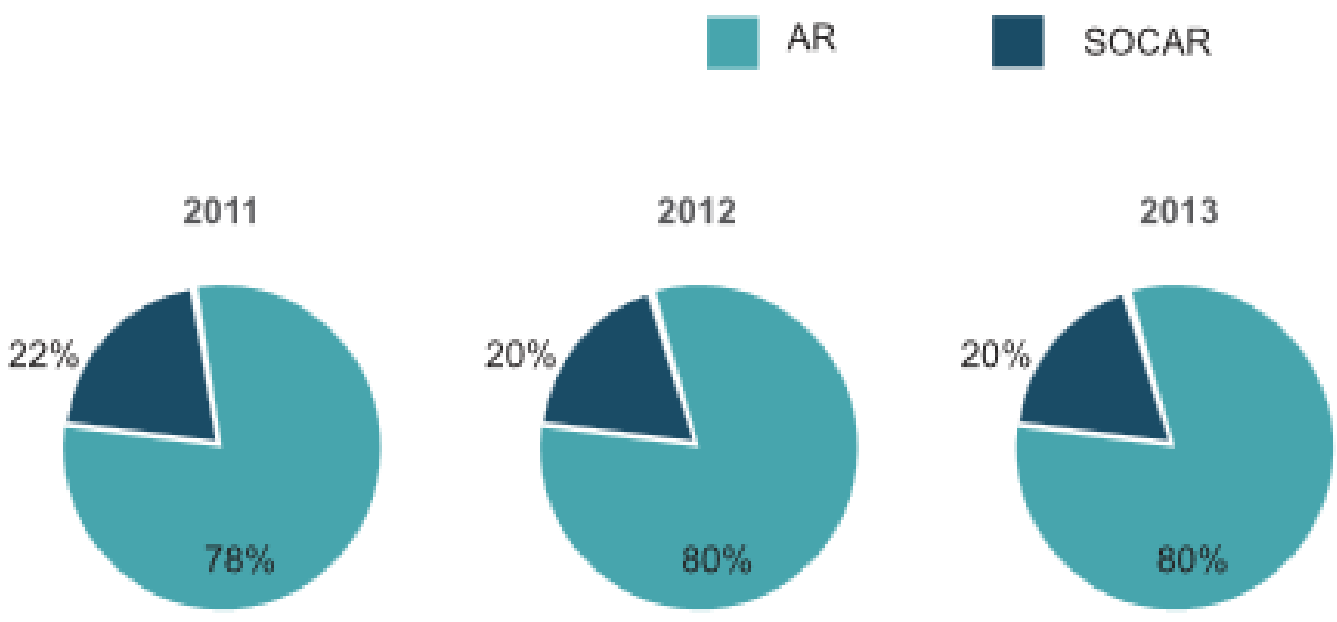

Source: SOCAR

Note: $A R=$ Azerbaijan Republic - includes gas production with foreign companies .

According to the reservoir engineering and reserves analyst company "Miller \& Lents", as of January 2014 SOCAR's proven gas reserves were $61.15^{69}, 70 \mathrm{bcm}$, deriving mainly from the above mentioned fields (including SOCAR's share of Shah Deniz gas) and from fields that are under development (e.g. Umid) (Figure 15).

\footnotetext{
${ }^{66}$ Azərbaycanın qaz ehtiyatının həcmi açıqlandı, ANS Press, http://anspress.com/index.php?a=2\&cid=2\&lng=az\&nid=294277, 5 September 2014

${ }^{67}$ Company's Annual Sustainable Report 2013, http://www.socar.az/socar/assets/documents/en/socar-annualreports/sus.dev.rep-2013.pdf, p. 6

${ }^{68}$ Company's Annual Sustainable Report 2013

${ }^{69}$ Azərbaycanın qaz ehtiyatının həcmi açıqlandı, ANS Press, http://anspress.com/index.php?a=2\&cid=2\&lng=az\&nid=294277, 5 September 2014

70 SOCAR's Annual Sustainable Development Report 2013,

http://new.socar.az/socar/assets/documents/az/socar-annual-reports/davamli-inkisaf2013.pdf, available in Azerbaijani
} 

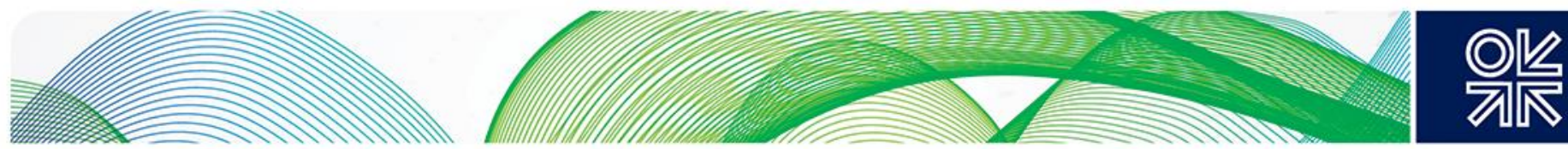

Figure 15: Natural gas production from key fields, (million cubic metres/day)

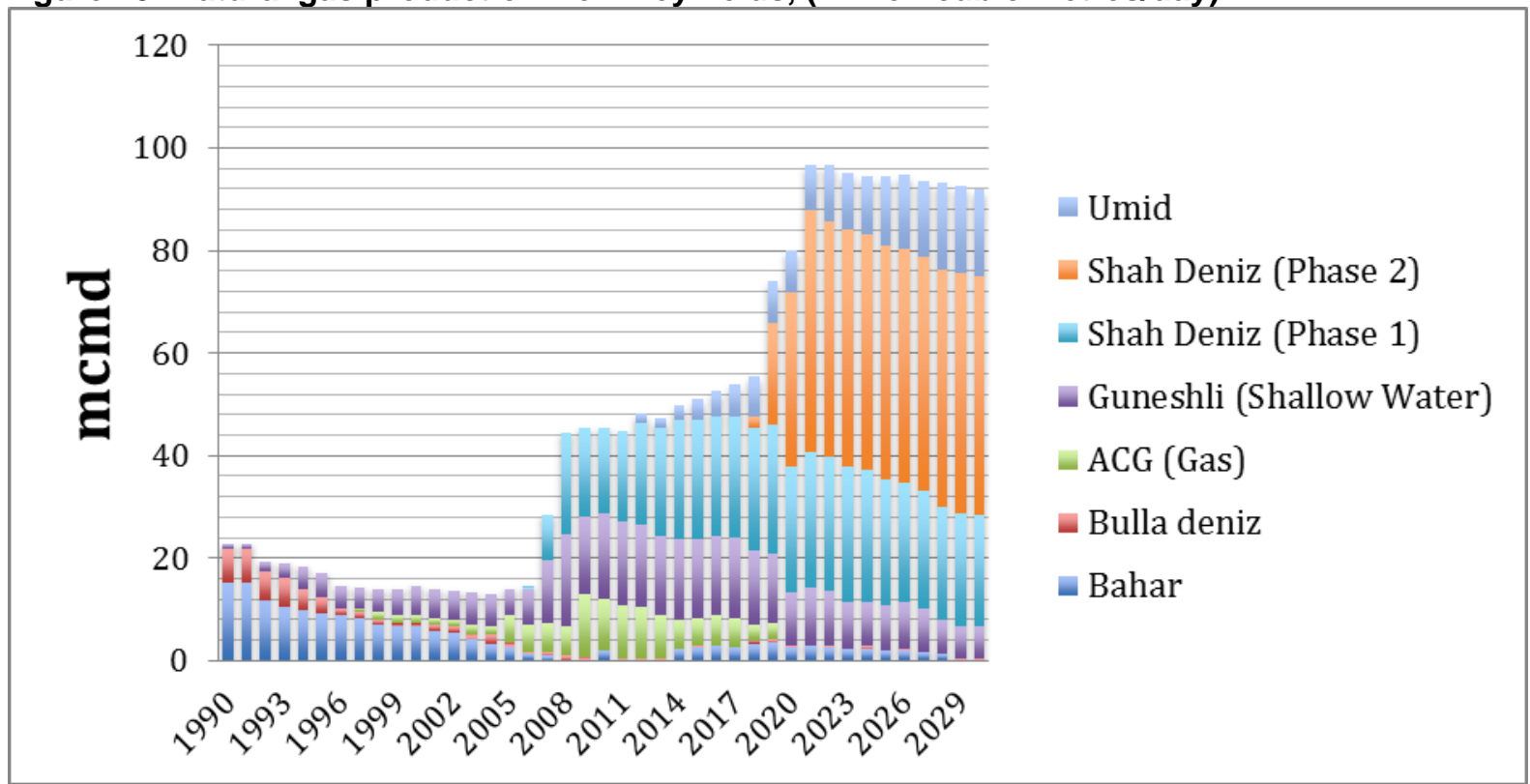

Source: Author's calculations and estimates

\subsection{ACG Associated Gas}

ACG is a large complex block of oil and gas fields in the Caspian Sea about $120 \mathrm{~km}$ off the coast of Azerbaijan (Map 8). Along with oil production, approximately $2.5 \mathrm{bcm} / \mathrm{a}$ or 6.8 million cubic metres/day of associated gas is extracted from the field. This gas is delivered by the ACG project partners to SOCAR free of charge in accordance with the PSA agreement, and is used to supply consumers in Azerbaijan, who pay regulated tariffs

\section{Map 8: Azeri-Chirag-Guneshli field}

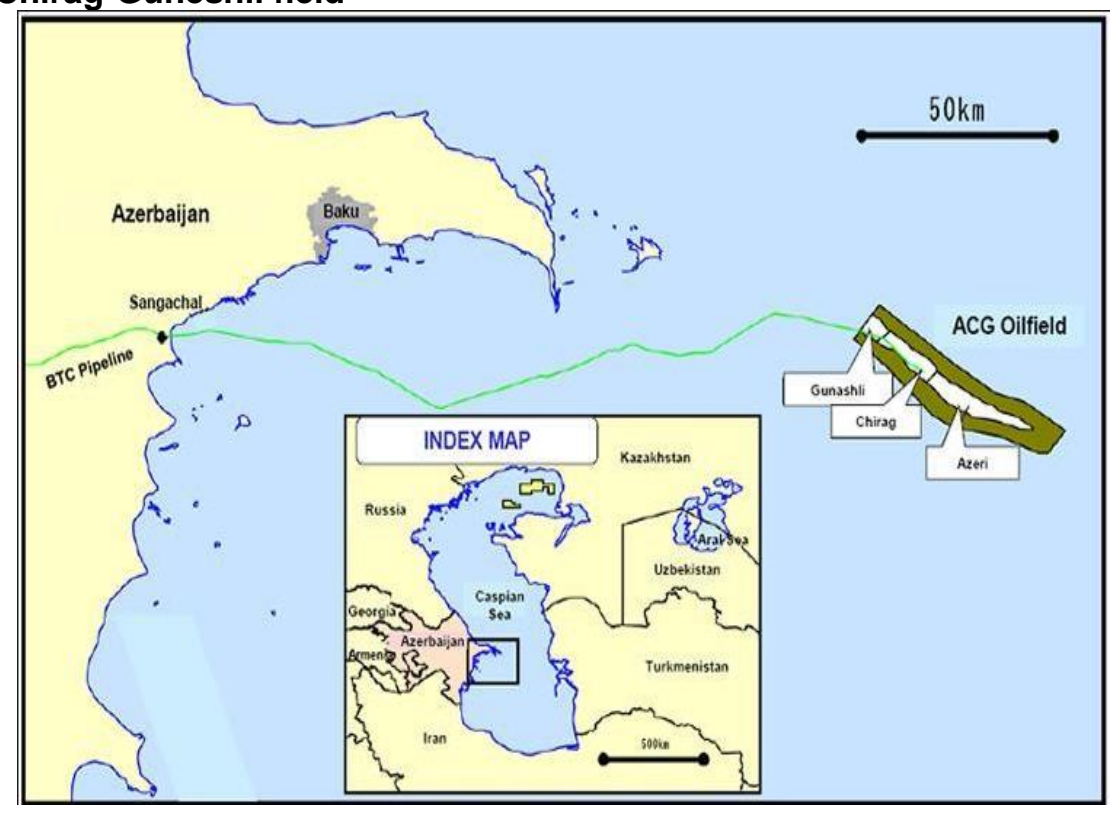

Source: Public domain

The future volumes of gas production from the ACG field depend on the requirement to re-inject gas into the reservoir to maintain pressure and hence maximize oil recovery and maintain production 

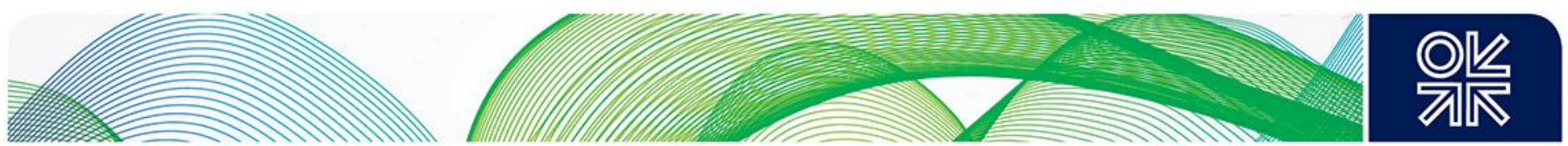

rates. Through time it is likely that the gas injection requirement will increase, and hence the volume of associated gas transferred to SOCAR from ACG and Shallow Water Guneshli may gradually decrease in the future.

Table 5: ACG associated gas production transferred to SOCAR, bcm

\section{Source: BP}

\begin{tabular}{|ll|}
\hline Year & Volume \\
2009 & 4.0 \\
2010 & 3.4 \\
2011 & 3.3 \\
2012 & 3.4 \\
2013 & 2.19 \\
2014 (estimate) & 2.4 \\
\hline
\end{tabular}

It is estimated that $2.4 \mathrm{bcm}$ of gas was transferred to SOCAR in 2014 (Table 5). This assumption is based on data for the first 6 months of $2014-1.2 \mathrm{bcm}(6.6 \mathrm{mcm} / \mathrm{d})^{71}$. This gas is transported from the Central, Western and Eastern Azeri platforms to Sangachal terminal via a 28 inch subsea gas pipeline. After treatment in the Sangachal gas processing plant, these volumes are transferred to SOCAR, whose Azerigaz Productions Unit is responsible for distribution on the domestic market.

As of 2014, the total associated gas volume transferred to SOCAR by AIOC (Azerbaijan International Operating Company) from ACG since production began was approximately $20 \mathrm{bcm}$.

Since 2007, gas production at the Guneshli (shallow water) field has increased steadily. This is mainly due to extensive exploration and further drilling by SOCAR, as well as improvements in the collection of associated gas and a reduction of volumes being flared and vented.

\subsection{Gum Deniz - Bahar/Bahar 2}

The Bahar field is located offshore to the south-east of the Absheron Peninsula (Map 9) and began production in 1969. It consists of producing reservoirs in the Balakhany, Pereryv, Girmekiustu, and Girmekialti strata. 203 wells have been drilled since the field went into development until April 1, 2011. As of January 1, 201316.9 million tonnes of condensate and $12.9 \mathrm{bcm}$ (annual production is $2 \mathrm{bcm}$ ) of natural gas had been produced at the field. Based on SOCAR's estimates, the remaining gas reserves of the field are $60 \mathrm{bcm}$.

\footnotetext{
${ }^{71}$ BP-Azerbaijan company's report for six months, 2014, 

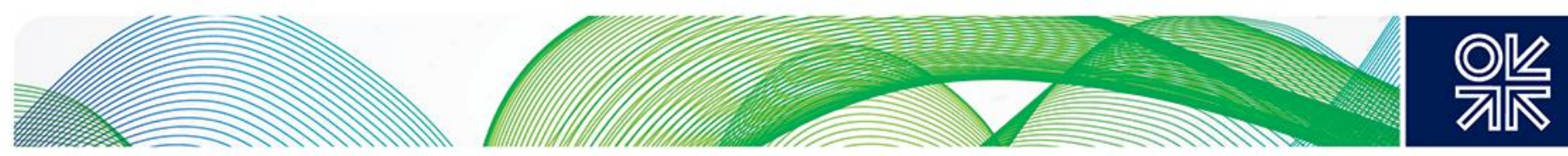

Map 9: Bahar ERDPSA - Offshore Shallow Water, Caspian Sea

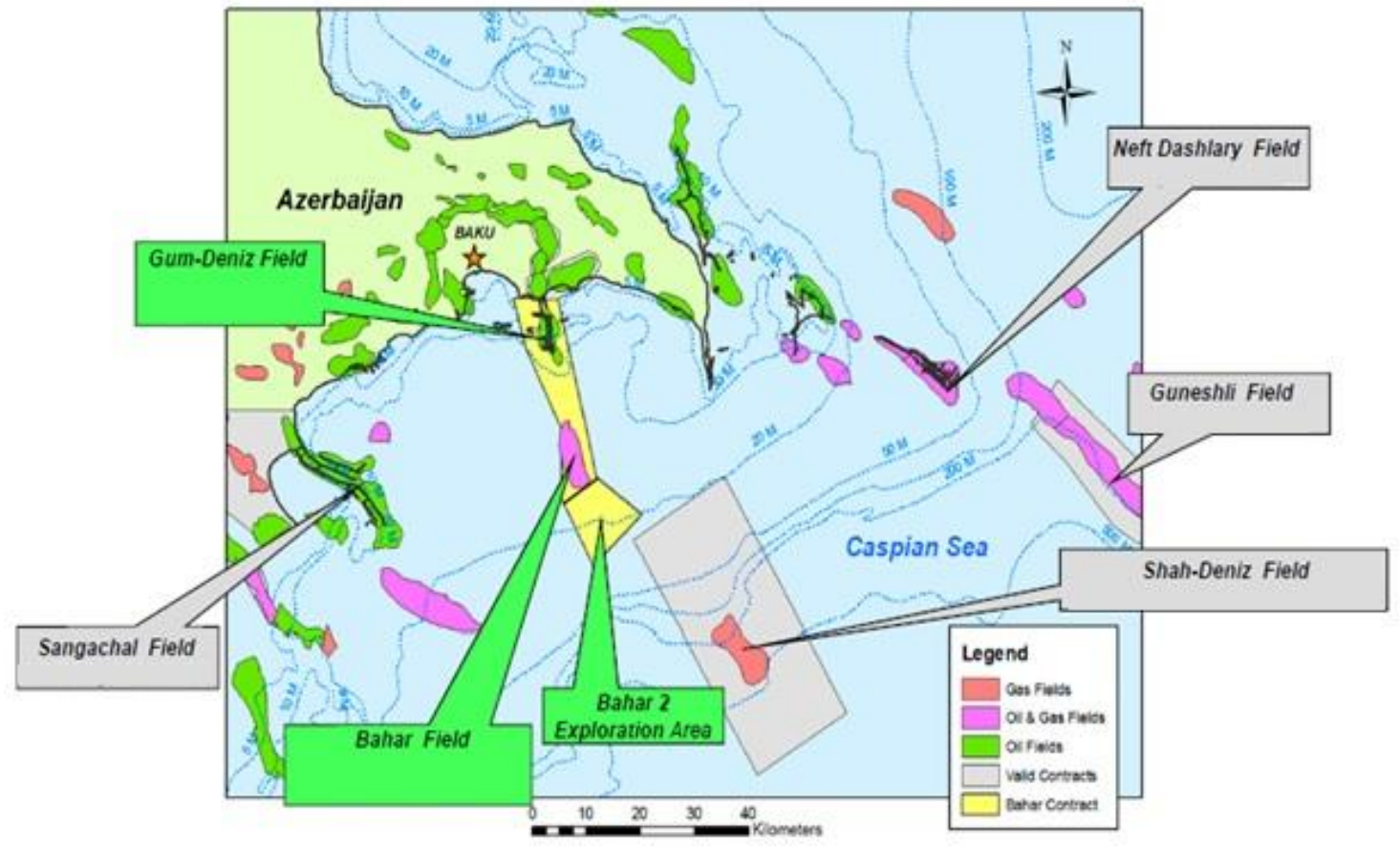

Source: Greenfield Petroleum

The Gum Deniz field is located offshore in shallow water (less than $10 \mathrm{~m}$ ) $21 \mathrm{~km}$ south-west of Baku and is located along the Fatmai-Gum anticline from the Bahar gas field. Development of this field began in 1955. 491 wells were drilled from the time the field went into development up to April 1, $2011^{72}$ and it had produced approximately $17.5 \mathrm{bcm}$ of gas by 2013 .

Bahar Energy entered into an Exploration, Rehabilitation, Development and Production Sharing (ERDPSA) Agreement with SOCAR and its wholly owned oil affiliate, SOCAR Oil Affiliate (SOA) on December $22^{\text {nd }}$ 2009. The Bahar project includes the Bahar gas field and the Gum Deniz oil fields, with the contractual area covering $309.7 \mathrm{~km}^{2}$. The consortium members are: "Bahar Energy Limited", which holds an $80 \%$ participating interest and SOA, which holds the remaining $20 \%$. This venture became effective on October 1 st, 2010. The ERDPSA covered both a rehabilitation area and an exploration area. The development and production period has a term of 25 years which may be extended by mutual agreement for an additional 5 years. The exploration period in the exploration area will have an initial term of 3 years which can be extended for one year at the request of the contractors. In the event of commercial discovery at the area, the development and production period will have a term of 25 years. The strategy of the partners in the Bahar Gas Field and the Gum Deniz Oil Field is to increase existing production and develop previously discovered proved undeveloped reserves.

Both fields are part of a rehabilitation area within the Bahar Project ERDPSA which also contains an exploration area located south of the Bahar gas field.

According to SOCAR's preliminary estimates, Bahar 2 has probable reserves of $18-25 \mathrm{bcm}$ of gas with possible annual production of $1 \mathrm{bcm}$. Under the second part of the contract, it is planned to drill

${ }^{72}$ SOCAR's official web page: http://www.socar.az/socar/en/activities/production/bahar-gum-deniz 

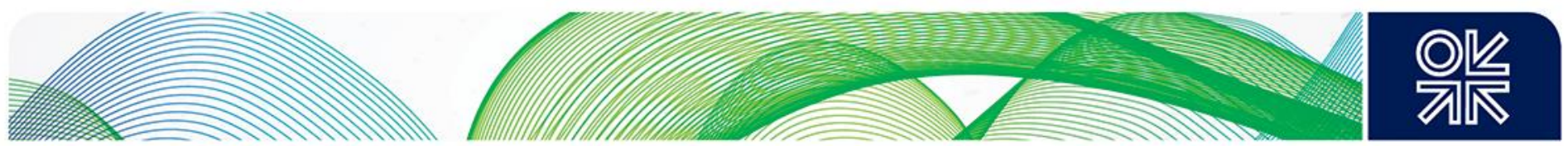

one exploratory well on Bahar 2, which has the geographical location between Bahar and Shah Deniz, within 2 years and another well in the third year.

\subsection{Bulla Deniz}

The Bulla Deniz offshore field was discovered in 1973 and became operational in 1975. On October $21^{\text {st }} 2009$, the drilling of Exploration Well No. 89 began at the Bulla-Deniz Area 2, on the far southeast of the Bulla Deniz Field.

The drilling target well depth was $6,400 \mathrm{~m}$, and the target horizon was Horizon VII of the Productive Strata (PS). Drilling was completed at a depth of $6,505 \mathrm{~m}$ on April $25^{\text {th }}$ 2011. The well penetrated PS Horizon VIII. PS Horizons V and VII (similar to Pereryv), and VIII (similar to the Girmaki Sand Horizon) were appraised as potential oil and gas bearing structures. At present preparations are being made for well completion.

In 2013, during the exploration and appraisal drilling at a depth of 5,686 metres, new horizons of natural gas were opened up; SOCAR estimated the volumes at around $10 \mathrm{bcm}$. In 2013, SOCAR produced approximately $341 \mathrm{mcm}$ of gas, up to 35,000 cubic metres of gas condensate and up to 24,000 tonnes of associate of gas ${ }^{73}$ annually from the field, for domestic consumption.

\subsection{Summary}

The current annual natural gas consumption in Azerbaijan is around $10 \mathrm{bcm}$. SOCAR supplies gas for the domestic market from its own portfolio. The country's gas demand is unlikely to grow significantly in the next years. However, with the current low price for oil (around $\$ 60 / \mathrm{barrel}$ as of early March 2015), the government of Azerbaijan is most likely to limit state investment in industrial projects that have lower priority. The current level of gasification of the country is $90.4 \%$. In Baku it is $99.1 \%$ and in other regions $84.3 \%{ }^{74}$. Following the progressive installation of metering equipment, residential consumption has decreased, however the demand in power generation could increase slightly $(90 \%$ of the current power generation is now using natural gas as feedstock).

SOCAR receives its gas mainly from ACG (more than 2 bcm/a), Oil Rocks, Gum Deniz/Bahar, Bulla Deniz, Sangachal-Deniz-Duvanli-Deniz-Harazire (in total $7 \mathrm{bcm} / \mathrm{a}$ ), but also $1.5 \mathrm{bcm} / \mathrm{a}$ from SD1 in accordance with the contract SD PSA.

In 2013, the total volume of gas SOCAR received from SD phase 1 was $4.8 \mathrm{bcm}$. Accordingly, SOCAR had 2-3 bcm additional gas which it exported to Georgia $(0.5 \mathrm{bcm})$, Iran (more than $0.4 \mathrm{bcm}$ ) and Turkey (up to $2 \mathrm{bcm}$ ). However, it is most likely that this will not be the case in future years, as following the construction of new compressor stations in the east of Turkey BOTAŞ will be able to offtake its full contracted volume from SD1.

With SOCAR's own natural gas production declining, the company has launched a strategy of investing to increase recovery and production on these fields. Despite this, given the maturity of its existing fields, SOCAR will be looking more to production from within the joint ventures (currently ACG, Shah Deniz, Umid, and also from the next wave of production in the future) offshore in the Caspian Sea.

\footnotetext{
${ }^{3}$ Figures obtained from SOCAR

74“Iki Sahil” journal, R.Abdullayev'v article. \# 25 (6200), 20 September 2014, available in Azerbaijani
} 

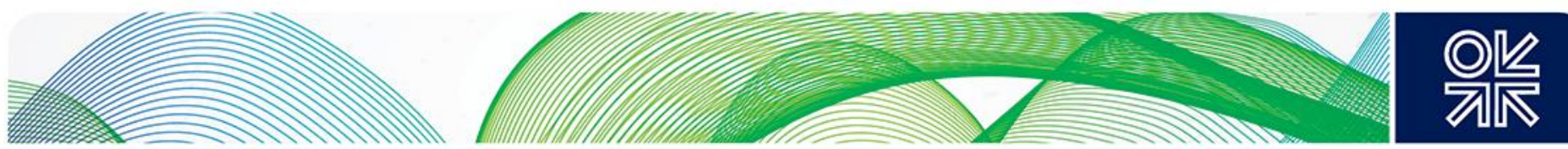

\section{Drilling Rigs in Azerbaijan}

Oil and natural gas offshore drilling rigs are massive structures which allow oil and gas wells (whether for exploration or appraisal) to be drilled in a range of water depths. Jack-up rigs, once towed to the drilling location, are held in position and supported by legs which are lowered to the seabed. The rig is then raised above the water surface prior to the start of drilling. In deeper waters floating rigs (semisubmersibles) are used which are anchored in position for drilling. These structures are fitted with a drilling derrick and pipe handling equipment, drilling pipe storage facilities, mud preparation, handling and storage tanks, hydrocarbon handling equipment including flare booms, the rig control centre and the accommodation facilities for the crew. In Azerbaijan all the current drilling rig fleet was constructed on the Absheron peninsula with some equipment components brought from abroad. Because of the size of such rigs, it is impossible to transport them, fully assembled, into the Caspian Sea due to the width restrictions of the Volga-Don Canal.

There were four operational rigs in the South Caspian sector in the 1990s. Currently, there are only three semi-submersibles drilling rigs in the Azerbaijani sector - Dada Gorgud, Istiglal and Heydar Aliyev. The Gurtulush jack up rig (Trident 20), which was ordered at a cost of $\$ 175$ million was released to Kazakhstan in 2003. The construction order was initiated by the Rig Club-2 consortium which included Elf, and included the licence-holders of the LenkoranTalysh, Oguz, YananTava and Kur Dashi blocks (operated by TotalFinaElf, Mobil, JAPEX and Agip respectively). Because the number of rigs has historically been limited in the Caspian Sea, one of the main issues in planning an exploration well and any new drilling is rig availability.

The rigs available now are as follows:

\section{Heydar Aliyev / Maersk Explorer (formerly named Leader and DSS-20)}

The Heydar Aliyev rig is currently involved in drilling a well in the Shah Deniz field. In February 2001, Maersk Contractors were awarded a three-year drilling contract for five wells by ExxonMobil and ChevronTexaco. The contract, which was signed on February 12001 , entailed building a new semisubmersible rig, the DSS-20, for operation in the southern Caspian.

The new rig, which was renamed Heydar Aliyev, was completed in 2003, and became the largest and most powerful unit in the Caspian Sea. It is capable of drilling in water depths of 1,000 metres, corresponding to some of the deepest areas in the Caspian, and is able to drill wells up to a depth of 9,140 metres. The rig is equipped with three drilling pumps $(3 \times 2.200 \mathrm{hp} / 7.500 \mathrm{psi})$ and accommodation for 130 people. Construction of the rig was undertaken by Keppel FELS in Singapore and the Caspian Shipyard in Baku and cost US \$250 million.

The Heydar Aliyev was used to drill ExxonMobil's Zafar-1 well in 2004 and LUKoil'sYalama well in 2005. In July 2007, the Heydar Aliyev drilled in the Maersk-operated blocks in the Turkmen sector of the Caspian Sea and then returned to LUKoil in April 2008 to drill the second exploration well on the Yalama structure.

The rig drilled the X2 well in Total's Absheron field in 2012. Currently it is drilling wells on the complex west flank of the Shah Deniz field as part of the Phase 2 development.

\section{Dada Gorgud}

The Dada Gorgud semi-submersible drilling rig is currently hired by the Azerbaijan International Oil Company (AIOC) for batch drilling. Prior to that, the rig was used for several years at the Azeri- 

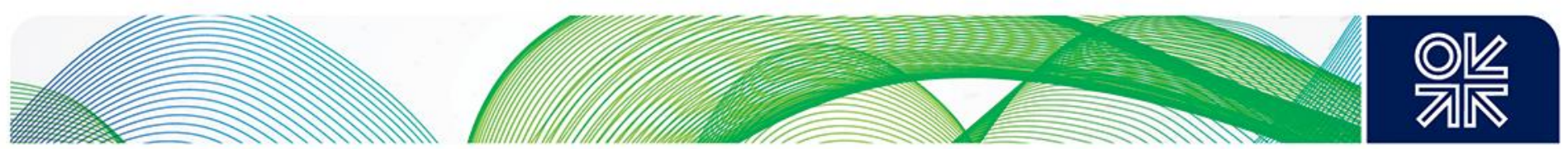

Chirag-Guneshli field as well as in SD (SDX\#1) in 1998. It was also used in drilling of exploration wells in Garabakh in 1997, Ashrafi in 1997, Dan Ulduzu in 1998 and Inam in $2001^{75}$.

The 'original' Rig Club (Rig Club-1) was formed by the four companies (AIOC, CIPCO, NAOC and BP), operating the earliest offshore contract areas in the country, in March 1997. According to agreements reached by the club, the members shared the utilization of the Dada Gorgud rig and access to the Istiglal (Shelf-5).

SOCAR conducted discussions with Exxon, Chevron and Agip to propose the upgrade of the rig to full deep-water capability. The deep-water operation companies also addressed the upgrade of the Shelf3 semi-submersible rig.

In 1999, SOCAR proposed solving the problem of the ongoing rig shortage as a matter of urgency in cooperation with the deep water operators, which included BP in addition to Exxon, Chevron and Agip. As a result, the Dada Gorgud underwent a five-month upgrade during the second half of 2000 at a cost of $\$ 36$ million. Despite the upgrade, the rig did not have the same pressure capability as the Istiglal (see below). In 2001 the first well at Inam was drilled by the Dada Gorgud following its upgrade, however the drilling could not be completed due to high formation pressures (11,750 psi), and the well was subsequently completed by the Istiglal rig.

After a further six-month modernization of the Dada Gorgud, completed in March 2002 at a cost of $\$ 10$ million, the rig can now drill to depths of 7,620 metres in water depths of up to 475 metres.

\section{Istiglal (Shelf-5)}

The Istiglal semi-submersible rig was first built in 1991 in Astrakhan and re-built in Baku in 1998. Currently the rig is hired by the SD consortium and used in drilling the SDX 7A well in the SD field. It was also used on Inam in 2001, Absheron in 2001 and Nakhchivan in $2002^{76}$.

The rig underwent a 20-month upgrade in Baku which was completed in 1999, at a cost of $\$ 210$ million. After the upgrade the rig is able to drill to depths of 7,620 metres in water depths up to 700 metres and to drill through the over-pressured formations prevalent in the deeper water South Caspian Basin. Despite the upgrade, when the rig re-entered the first exploration well on the Shah Deniz contract area in 1999, it suffered a number of operational failures, partly due to the fact that the casing design had been planned based on utilisation of the Dada Gorgud rig. The major problem was the failure of three generators, which forced the operator to use the Dada Gorgud rig for well completion. Prior to the Shah Deniz field (where the rig was used to drill the SDX 6, SDX 7, SDX 7A wells since March 2011), the Istiglal rig had been used by the AIOC at the ACG field in 2010 and by BP to drill the INX 2 well in the Inam block in $2008^{77}$.

\section{The new rig (under construction)}

The Azerbaijani Caspian Drilling Company Ltd, a subsidiary of SOCAR, has ordered the construction of a new semi-submersible drilling rig by Keppel Offshore \& Marine Ltd (Keppel O\&M) through its subsidiaries Caspian Rigbuilders BV (an affiliated company of Keppel FELS). The cost of the construction is approximately one billion USD, which will include owner-furnished equipment. It is not the first project undertaken by Keppel in Azerbaijan. It has a track record of completing rigs for the Caspian Sea, having delivered the first semisubmersible (the DSSTM 20 Maersk Explorer, renamed the Heydar Aliyev), jackup rig (Transocean's Trident 20 jackup rig) and ice-class Floating Storage and Offloading (FSO) vessel built in-country. This was done in collaboration with its sister yards in Singapore which fabricated modules that were then shipped through the Volga Don Canal for completion at the Caspian Shipyard Company.

\footnotetext{
${ }^{75}$ Caspian Drilling Company's website, http://www.caspiandrilling.com/browse.php?sec id=12 ${ }^{76}$ Caspian Drilling Company's website, http://www.caspiandrilling.com/browse.php?sec id=13 77 ibid
} 

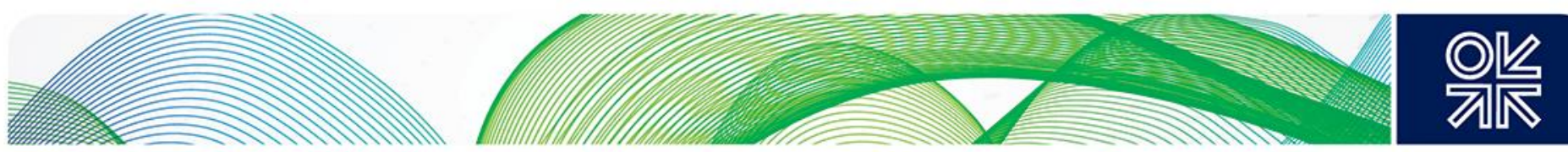

It is planned that the rig will be delivered by Q1 of 2017 and will be designed to Keppel FELS' proprietary DSSTM 38M design, which has been customised for the Caspian Sea's harsh environmental conditions.

The DSSTM 38M is designed for a drilling depth of up to $40,000 \mathrm{ft}$ and operations in 1,000 metres water depth. To meet the customer's requirements, it has been outfitted to include an 800 metre selfcontained eight point mooring system designed to meet high wind speeds in the harsh Caspian environment. The pontoons have been designed for the rig to transit in channels with shallow draft of less than seven metres ${ }^{78}$.

The DSSTM 38M is designed in a way that will be applicable to use in all the fields and prospective structures. It will be technically possible to drill on the Absheron field as well as Umid/Babek, ACG deep, and other structures. This new next-generation rig will provide the opportunity for SOCAR to expand its offshore drilling programme.

SOCAR intends to build more rigs in the near future. It is planned that in the next 2-3 years SOCAR will start building one more new rig in its sector of the Caspian.

\section{Summary}

The timing of future oil and gas production in Azerbaijan relies heavily on rig availability. Currently it is uncertain what SOCAR will decide with regard to the deployment of the newly constructed rig, once it is available in 2017, whether on SD Phase 3, Absheron, ACG non-associated gas, or drill more wells in ACG to increase oil production or Umid/Babek, once the tender is finalized. The first contender for production, the Absheron field, is expected to be granted a rig by 2018 at the latest to start production in late 2021. If Absheron does not get access to the new rig, in order to avoid delay the operator of the project, Total, will most likely have to jointly build a new rig. Alternatively it could proceed with a phased development of the field with the production platform drilling deviated appraisal wells in addition to development drilling on the better known, low risk field segment.

With the construction of a second new rig, and a freed up rig from the SD2 field in approximately 2027, as well as the Dada Gorgud rig from the ACG in around 2024, four rigs will be available in the 2020s for drilling exploration, appraisal and development wells of the fields mentioned above. 

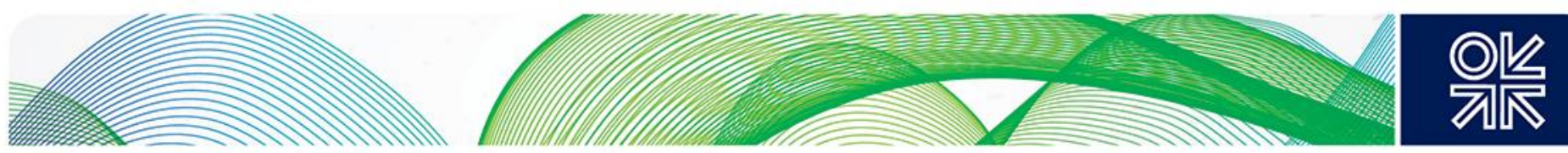

\section{Commercial Natural Gas Reserves and Partially Appraised Discoveries: Absheron, ACG Non-Associated Gas, Umid and Babek}

This section focuses on both proved reserves and potential resources. This includes gas fields (commercial reserves) that are in production and also discoveries which are the subject of further appraisal which we consider to be contenders for development in the near to medium term, i.e. by the 2020s (probable developments). Together these are referred to as 'Group 1'. Group 2 Resources (prospective structures, and so called technical reserves), are either prospects which have not yet been the subject of (sufficient) exploration drilling, or accumulations which have not been demonstrated to be commercially viable. Group 2 resources are addressed in Section 6 .

As Azerbaijan has been producing oil and gas for over 150 years, many of the onshore fields have been largely depleted, although some potential remains in the renovation of ageing fields, development of deeper reservoirs and exploration for non-structural traps. The greatest potential lies in the offshore, where a number of large structural closures (potential reservoirs) have been identified from seismic data, in water depths ranging from 30 metres to 1,000 metres. The first wells in the deeper water part of the basin seemed to confirm this potential, at least for gas and condensate, with fields such as Shah Deniz and Umid.

It is important to note that the Azerbaijani resource classification differs from that generally used by IOCs and is based on the Soviet "Classification of deposits, reserves, perspective and prognostic resources of oil and fuel gas"79.

There are some fundamental differences between western oil company and FSU (Former Soviet Union) methods of estimating recoverable reserves, principally in the application (in standard western company methodology) of economic criteria in determining recovery factors and, as a result, historic Soviet reserves often tend to be significantly higher than western equivalents ${ }^{80}$.

Azerbaijan uses the 1983 former Soviet classification, based on the degree of exploration and appraisal drilling of a hydrocarbon accumulation. The Azerbaijani method of estimating recoverable reserves is based on a "maximum recovery factor" which assumes technical and economic conditions, which are theoretically possible in the future. Taking into account the field size distribution, quality of reservoirs and distribution between free, gas cap and solution gas, the 'over-statement' of total gas reserves may be in the region of $25 \%$ compared with western IOC estimates ${ }^{81}$.

As shown in Table 6, reserve and resource categories A, B, C1 and C2 (reserves) and C3, D1 and D2 (resources), reflect the level of exploration, appraisal and development activity which has been applied to a field or segment of a field ${ }^{82}$.

\footnotetext{
${ }^{79}$ This classification was in use in 1983-1991 and is the form of classification that the "Caspian Geophysical Company" owned $50 \%$ by SOCAR widely uses till now.

80 J. Stern, The Future of Russian Gas and Gazprom (Oxford, OUP, 2005), pp. 60-63

81 lbid

82 Ibid
} 

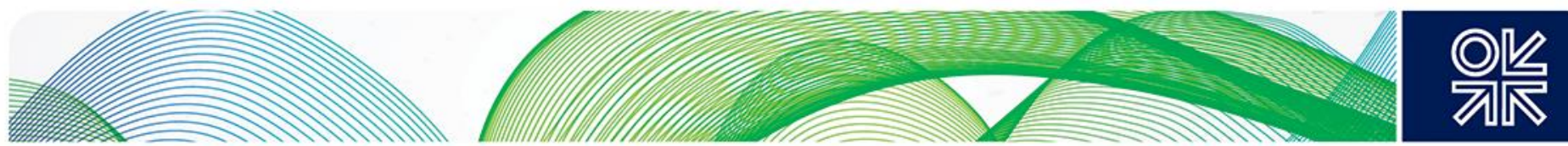

Table 6: Azerbaijani Reserves Classification

\begin{tabular}{|l|l|}
\hline \multicolumn{2}{|l|}{ Table 6. Azerbaijani reserves classification } \\
\hline Reserves & $\begin{array}{l}\text { Fields that are drilled and producing, and sufficient } \\
\text { details of type, shape and size of the deposit are } \\
\text { available }\end{array}$ \\
\hline B & $\begin{array}{l}\text { Fields certified for the drilling of development wells. The } \\
\text { reserves have been determined at the field at various } \\
\text { depths, based on commercial flows of oil and gas, and } \\
\text { information on type, shape and size of the filed is } \\
\text { determined }\end{array}$ \\
\hline C1 & $\begin{array}{l}\text { Reserves of deposits where the availability of oil and } \\
\text { gas has been determined, based on appraisal wells } \\
\text { drilled and pool tested, and positive results from } \\
\text { geological and geophysical exploration }\end{array}$ \\
\hline C2 & $\begin{array}{l}\text { Preliminary estimated reserves, with exploration wells } \\
\text { drilled but no firm exploitation or development plans }\end{array}$ \\
\hline Resources & $\begin{array}{l}\text { Potential resources in which hydrocarbons are } \\
\text { demonstrated }\end{array}$ \\
\hline C3 & $\begin{array}{l}\text { Forecasted resources, i.e. commercial discoveries been } \\
\text { made based on seismic and geological data, but no } \\
\text { wells drilled }\end{array}$ \\
\hline D1 and D2 &
\end{tabular}

Source: J. Stern, The Future of Russian Gas and Gazprom (Oxford, OUP, 2005), pp. 60-63

Of particular interest are the volumes of gas in Azerbaijani fields in the $A$ and $B$ reserves categories which are not yet covered by existing contracts which may potentially be available for export between 2021 and 2030. This growing volume of gas will come mainly from fields that are under development or at the stage of appraisal drilling, following discovery, or have concluded a Production Sharing Agreement (PSA) prior to development, but before contracts have been signed.

The south Caspian deep water fields which fall into this category are: Absheron, Azeri-ChiragGuneshli Non-Associated Gas (ACG NAG), and Umid and Babek (Map 10). These accumulations are projected to ramp up production in the period 2021-2030 are shown in Table 7. Production growth from these projects depends on securing gas sales contracts with suitable buyers, the availability of drilling rigs, commerciality of the project itself and the availability of infrastructure, i.e. availability of free capacity to transport additional volumes to the markets. 

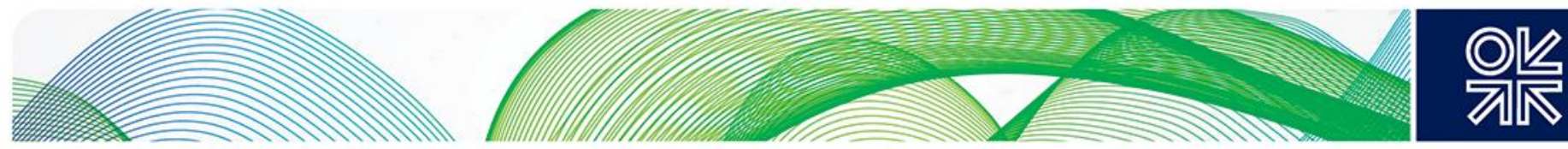

\section{Map 10: Offshore oil and gas fields/blocks in Azerbaijan}

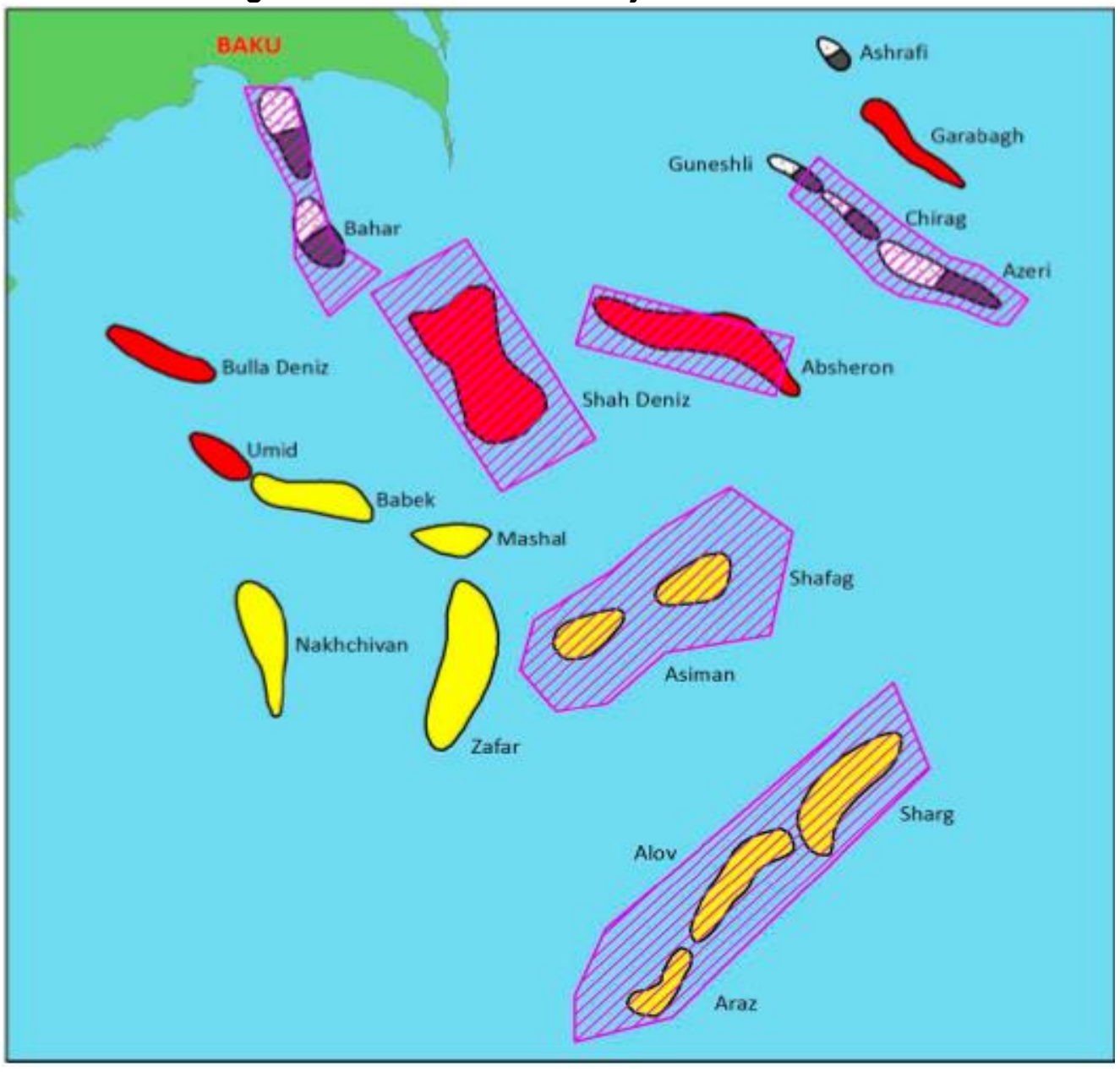

Source: SOCAR

These accumulations have a high likelihood of development due to having the following attributes:

- Existing or likely development plans

- Geological complexities resolved or partially resolved by exploration drilling and reservoir studies.

- The decision of the Azerbaijani government on fields which will be granted priority usage of a new semi-submersible drilling rig early in 2017 (once constructed); and,

- The stated commercial interest of the partners to complete appraisal and subsequent development works. 

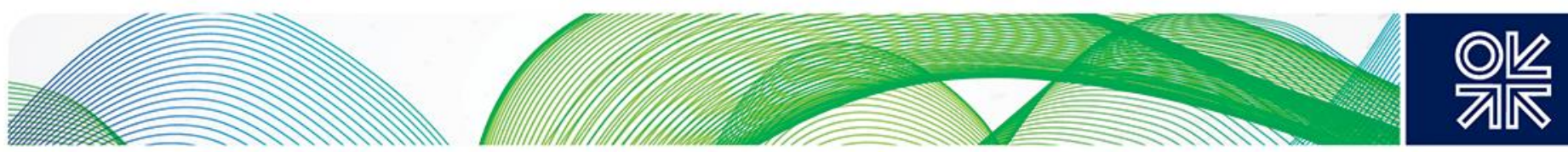

Table 7: Estimated reserves by discovery and development status

\begin{tabular}{|c|c|c|c|}
\hline Block & Reserves & $\begin{array}{l}\text { Development } \\
\text { status }\end{array}$ & $\begin{array}{l}\text { Estimated start date of } \\
\text { production }\end{array}$ \\
\hline $\begin{array}{l}\text { Absheron (Deep } \\
\text { Water) }\end{array}$ & $\begin{array}{l}80-350^{83} \mathrm{bcm} ; 45 \mathrm{mln} \\
\text { tonnes of condensate }\end{array}$ & Interim status & $2021-2022$ \\
\hline Umid & $\begin{array}{l}200 \mathrm{bcm} ; 40 \mathrm{mln} \text { tonnes } \\
\text { of condensate }\end{array}$ & $\begin{array}{l}\text { Tender for } \\
\text { development } \\
\text { announced }\end{array}$ & $2026-2027$ \\
\hline Babek & $\begin{array}{l}400 \mathrm{bcm}^{84} ; 80 \mathrm{mln} \text { tonnes } \\
\text { of condensate }\end{array}$ & $\begin{array}{l}\text { Tender for } \\
\text { development } \\
\text { announced }\end{array}$ & $2026-2027$ \\
\hline ACG NAG & $\begin{array}{l}280 \mathrm{bcm}^{85}, 45 \mathrm{mln} \text { tonnes } \\
\text { of condensate }\end{array}$ & $\begin{array}{l}\text { PSC has not } \\
\text { been concluded }\end{array}$ & 2027 - 2028 \\
\hline
\end{tabular}

Source: Author's Analysis, SOCAR

of condensate

Note: NAG is an acronym for Non-Associated Gas

These factors are analyzed for each of the four fields separately. Once these factors are identified, it is possible to estimate the approximate start-up of production by applying the following indicative durations for the three phases of field exploration and development:

- Exploration phase, approximately 3 years

- Appraisal phase, approximately 3 years and

- Development phase, minimum 5 years.

As all the four fields have already been discovered, there is no need to allow for 3 years of exploration work. Further appraisal works are necessary to reduce the uncertainty range on recoverable gas quantities. Offshore Azerbaijan, appraisal drilling programmes are dependent on the availability of semi-submersible drilling rigs, which, as discussed previously, is restricted ${ }^{86}$.

Taking into account the factors affecting timing, specifically the current development status of the four projects, the front-runner likely to take FID and achieve first production is the Absheron field. It is the only project that has secured a PSC contract. The second is the Umid/Babek field for which SOCAR has announced a tender to attract foreign investment, but consequently has no PSC yet. The third is ACG NAG, which is not yet covered by the terms of the existing ACG PSC. Negotiations are ongoing with the ACG partners to define the contract area specific to this gas potential.

\subsection{Absheron}

The PSA for the Absheron contract area, in which SOCAR held 50\%, ChevronTexaco $30 \%$ and TotalFinaElf the remaining $20 \%$, became effective on December $5^{\text {th }} 1997$. The PSA committed ChevronTexaco and its partners to a work programme which included two exploration wells in an initial license period of three years. The contract area is located on the shelf slope of the South Caspian Sea in water depths ranging from 300-650 metres (Map 10).

\footnotetext{
${ }^{83}$ The Absheron field size of $80 \mathrm{bcm}$ is "C2" and is the consortium estimate. $350 \mathrm{bcm}$ is the SOCAR "C2"+"C3" estimate.

${ }^{84}$ SOCAR's "C3" estimate

85 SOCAR's "C3" estimate

${ }^{86}$ Note the size restriction of the Volga-Don canal linking the Caspian Sea with the Black Sea precludes access to the global drilling rig market.
} 

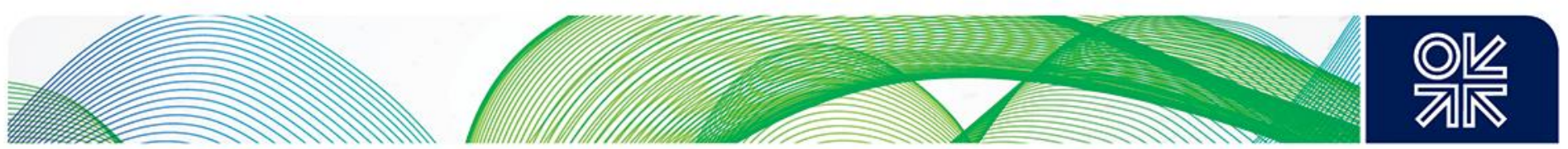

Given the geological characteristics and location of the Absheron contract area, it was thought that a discovery would be similar to Shah Deniz, and would have the capacity for similar gas reserves (possibly in excess of $10 \mathrm{tcf}$ ).

ChevronTexaco, the operator of the PSC, plugged and abandoned its first well on the block in July 2001 after encountering technical difficulties and the block was later relinquished. In June 2008, Total announced it was returning to the block. A new PSA was signed in February 2009, expiring in 2046. After a subsequent farm-out of $20 \%$ of Total's stake to GDF Suez in June 2009, the current participation is $40 \%$ Total, $40 \%$ SOCAR and $20 \%$ GDF Suez.

Preliminary estimates put Absheron reserves at $80-200 \mathrm{bcm}^{87}$ of natural gas and 45 million tonnes of gas condensate.

In January 2010, Total started drilling a new exploration well to a depth of 7,200 metres. The drilling proved to be very challenging due to the high pressure in the reservoir (up to $15,000 \mathrm{psi}$ ). The exploration well cost was around $\$ 300$ million with a drilling time of seven to eight months. In June 2012, Total completed the exploration well.

Currently the field has an interim development status as exploration work has been completed but the appraisal programme has not been started due to limited drilling rig availability. For this reason, and based on the results of its exploration well, Total has decided to proceed directly with the phased development process, potentially avoiding a delay of around four years. Current first production is estimated for late 2021.

It is likely that Total will focus the first development phase on the part of the reservoir where it has most confidence and possibly use development well results in combination with later appraisal drilling to reduce the uncertainty for subsequent development phases.

Total has prepared a draft of the Absheron development program which is expected to be approved by the end of 2015. This program includes the timeframe of the development phase of the field as well as a recoverable reserves assessment and daily and annual production forecast. At this stage, Total has defined a Phase 1 development with a $500 \mathrm{MMscf} / \mathrm{d}$ plateau (or $5 \mathrm{bcm} / \mathrm{a}$ ). The evolution of the plateau will be better understood with the data the consortium will collect once they start production. In the best case, despite of the risk of an early production decline, the project would continue until the end of the contract period which is 2046 .

If all the existing challenges are resolved in a timely manner, gas production from the field will commence in late 2021. The annual production forecast is $5 \mathrm{bcm} / \mathrm{a}$ and the project lifetime estimated for approximately 26 years.

\subsubsection{Challenges}

Clearly the availability of drilling rigs is a major challenge for the Absheron field and other discoveries. At present there are three operational drilling rigs in the South Caspian sector, as described in Section 4.

All these rigs are currently in use at Shah Deniz and ACG. The fourth semi-submersible drilling rig is being built in the vicinity of Baku at the Caspian Development Company (CDC) facility by Singapore's Keppel FELS. It is expected that the rig will be operational by the beginning of 2017 . Thus, any further exploration, appraisal or development drilling in Azerbaijan does not seem possible before 2017.

As discussed earlier, 2 new rigs will be available by early 2017 and late 2018, and 2 semisubmersible rigs will be freed up in the Azerbaijani sector of the Caspian Sea by 2024 and 2027 for deep water drilling. However, the question of on which field or prospective structure the Azerbaijani

${ }^{87}$ Industry estimate 

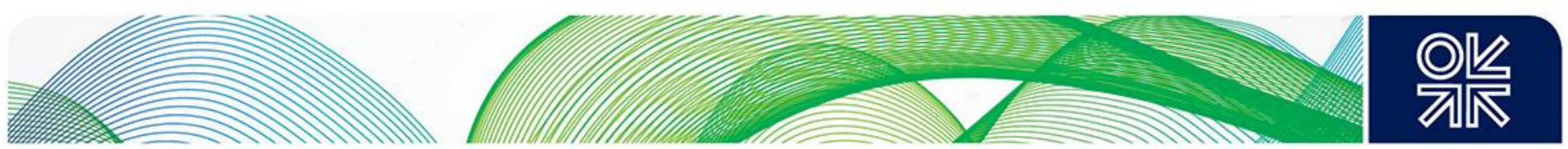

government will choose to deploy them is still a cause of uncertainty. It is not yet known what will be the form of the decision process: whether by tender or some other means.

The government of Azerbaijan might give priority to the most commercially profitable projects, which could be Shah Deniz Phase 3, or oil projects such as drilling more wells in the ACG field to increase the production of oil. The Absheron field is among the priority fields because the project is more advanced than in other recently discovered fields. For Absheron two possible options are available: use of SOCAR's new rig, which is currently under construction, if granted, and/or investment/joint construction of a second new rig in 2018-2019.

The second most important challenge that could affect the timing of the development process is the commercial viability of the project and the cost of development. The development of the Absheron field is likely to be high cost, due to the significant water depth and higher reservoir pressure $(15,000$ psi). For this reason, total expenditure is estimated at approximately $\$ 6.3$ billion. The Absheron exploration well cost was around $\$ 300$ million. It is expected that the gas from this field will be processed in the planed Oil \& Gas Processing Complex (OGPC) to be built in Baku by 2022.

A no less important factor affecting the commercial viability of the project is the gas price in the market by the time that the Absheron gas will come on-stream. However, the negotiations with the potential buyers need to start now, and the contract price basis should be agreed during the negotiations, before the final investment decision. At the moment, given the low oil price and hence oil-indexed gas prices and the low level currently of gas hub prices in Europe 2015, it is not the best time start such negotiations.

The gas price expectation needs to be sufficient to confirm economic viability in order to move to Front End Engineering Design (FEED) and subsequently to take the Final Investment Decision (FID) for the project.

\subsection{The Umid-Babek field}

The Umid-Babek field is located 75 kilometres sourth-east of Baku and 40 kilometres from land (Map 10). First geophysical work was conducted in this field in 1953 followed by further studies in 1972. From 1977 to 1992 there were 9 exploration/appraisal wells drilled. All wells were drilled by the "Khazar" semi-submersible drilling rig which can operate in water depths of 60-70 metres. SOCAR was able to reach horizon $\mathrm{V}$ with its own technology and capacity and deeper promising horizons $\mathrm{VI}$ to VIII were identified from seismic which will be drilled in due course (Figure 16). 

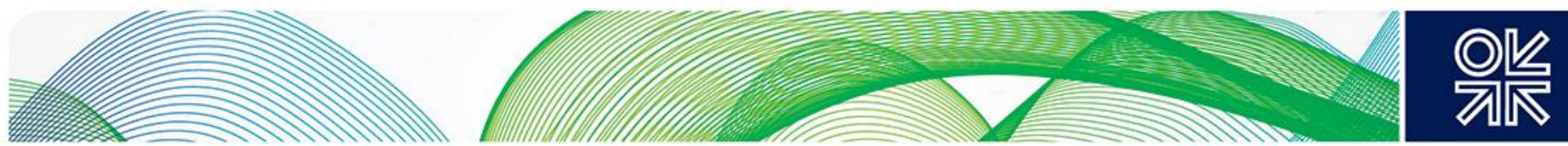

Figure 16: Geological structure of Umid-Babek field
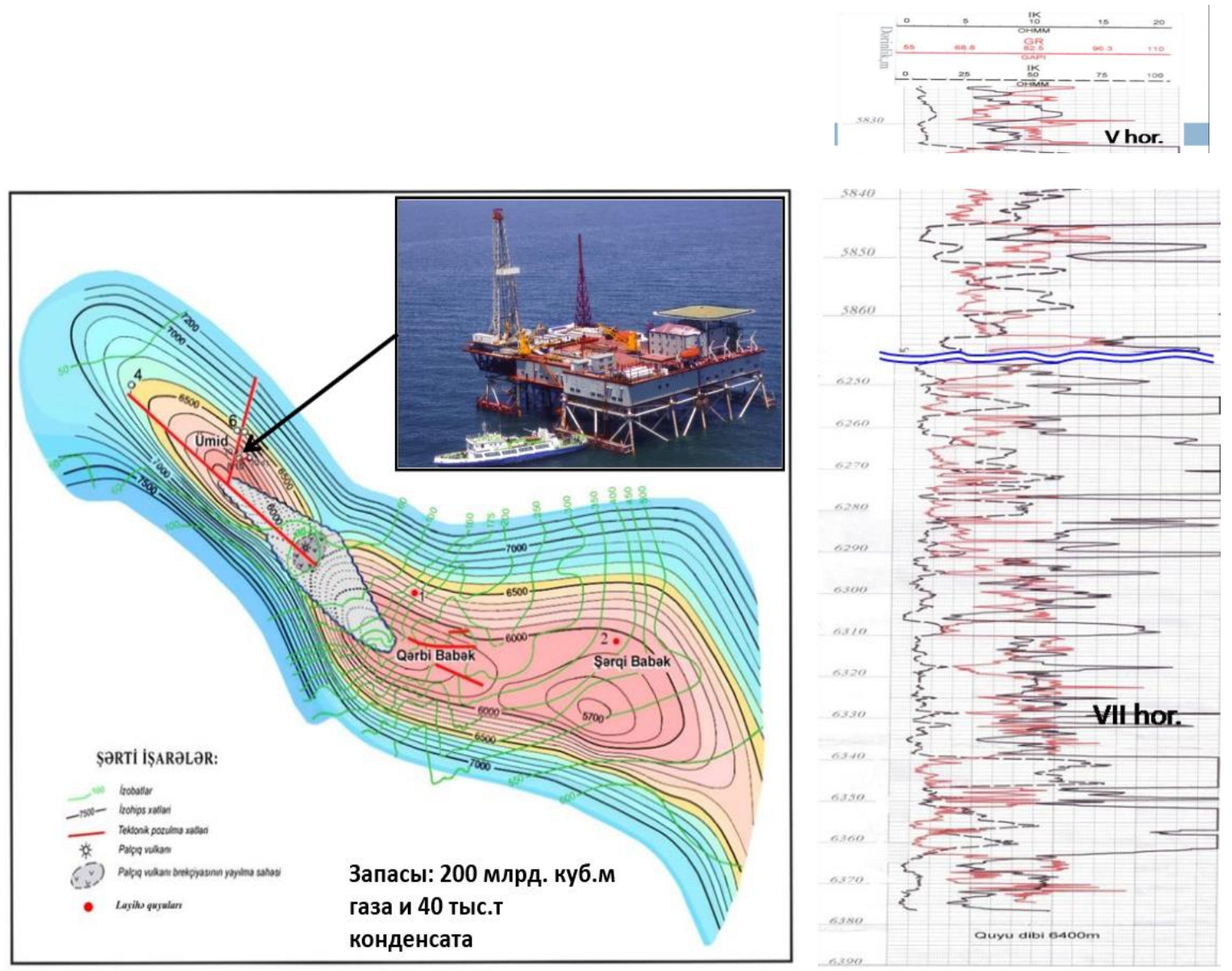

Source: SOCAR

The Babek prospective structure is located to the east of the Umid field and its maximum water depth is $500 \mathrm{~m}$. According to preliminary estimates, it contains up to twice as much natural gas and condensate as the Umid field.

SOCAR previously signed a Protocol of Intent with ConocoPhillips for this block in February 2005 which expired in February 2007. In December 2007, SOCAR announced plans to start independently exploring the offshore Umid-Babek block. Umid-8 was spudded in December 2007 from Platform One. Drilling was difficult and slow due to compact sandstones, and was suspended at 5,500 metres in 2009 for a substantial period before finally being deepened to a drilling of 6,006 metres. The planned drilling target depth was 6,500 metres and well completion was expected by the end of 2011 . However due to technical challenges it was not possible to complete the well. (The original well completion was scheduled for the first quarter of 2010). A well on Babek is to follow if the Umid well proves up commercial reserves. Umid-10 was spudded in May 2011 and was completed at the end of 2012. Preliminary estimates put Umid reserves at $200 \mathrm{bcm}$ and 225 million barrels of condensate. Babek pre-drill estimates by SOCAR are $400 \mathrm{bcm}$ and 80 million tonnes of condensate ${ }^{88}$. 

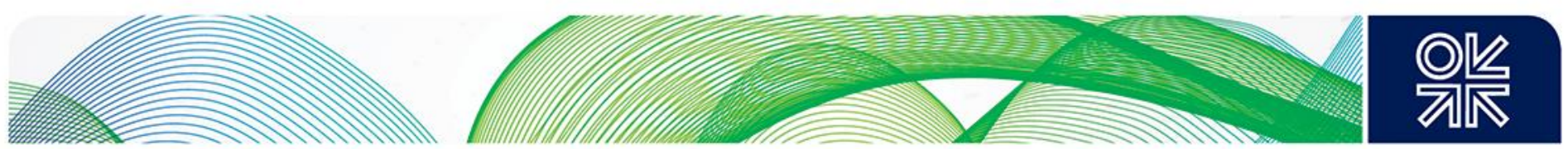

Currently, the Umid field has two wells in operation, which produce about $566.2 \mathrm{mcm} / \mathrm{a}^{89}$, or 47,000 thousand cubic metres/month, which is used for domestic consumption. The Umid gas field currently is operated by the joint venture "SOCAR-Umid" LLC ( $80 \%$ of the equity is owned by SOCAR and $20 \%$ Noble Oil, which has installed a modern drilling rig for exploration and production on a fixed platform). Since 2010 when first gas came online more than $390 \mathrm{mcm}$ of gas and 65,000 tonnes of condensate have been produced.

As mentioned above, SOCAR had originally intended to develop the Umid field and Babek prospective structure with its own resources and capability, without attracting international investment and partners. However, due to the complex geological conditions, advanced drilling equipment and significant financial investment needed for further development, it has changed its approach. SOCAR announced a tender for the joint development of the Umid gas field and the Babek prospective structure in September 201490. Currently SOCAR has suspended drilling of new wells in Umid because the winner of the tender may have a different approach to the development of this gas and condensate field. It is not clear whether Noble Oil will remain in the project, divest/increase its share after the tender.

The shortage of semi-submersible drilling rigs is an issue for the commencement of drilling in the 500 metres of water on the Babek structure. This can be resolved with the new rig that currently is being built in the Baku Shipyard by Singapore's Keppel FELS. However as with other fields and prospective structures, it is most likely that priority will be given to granting 2 available rigs in 2017 and 2018 to the most commercially viable and advanced project.

Because of the project's development status, and the uncertainty as to when a PSC will be signed, we assume that the project's appraisal and development phase will start after the Absheron field in 20182020 and take approximately 8 years. Consequently the projected timeframe for the Umid/Babek field's production might be by $2026-27$.

Considering the size of the field and the project lifetime (approximately 25 years) it is projected that the annual gas production from the Umid field will be ca. $1.5 \mathrm{bcm} / \mathrm{a}$ and from the Babek field ca. 3-5 $\mathrm{bcm} / \mathrm{a}^{91}$.

\subsection{Azeri-Chirag-Guneshli non-associated natural gas (ACG-NAG)}

The contract area of gas in the deeper layer of the ACG field (Figure 17) has yet to be defined. It has not been decided yet whether the deep gas layer and the second phase of development of ACG should be within the same PSA.

Presumably, there are two possible legal framework options within which the ACG deep layer gas could be further developed. The first option is to include the development of the deeper field reservoirs within the existing PSA dating from 1994. The other possible option is to treat the Phase two development of the field as a separate project and conclude a new PSA with the same and/or other partners. In this case, the gas would be defined as non-associated gas rather than deep layer gas and be considered as separate from ACG PSA project.

\footnotetext{
${ }^{89}$ SOCAR Annual Development Report, 2013, p.21, http://www.socar.az/socar/assets/documents/en/socar-annualreports/sus.dev.rep-2013.pdf

90 "SOCAR announces tender for the joint development of gas fields in the Caspian Sea", Contact.az http://www.contact.az/docs/2014/Economics\&Finance/091000089970en.htm\#.VBwSYxZ8gM4, 10 September 2014

${ }^{91}$ Note: In the description of SD2 and the Absheron field, the ratio of plateau annual production to reserves is around $6.5 \%$ (with the consideration of the Abseron field reserves of $80 \mathrm{bcm}$ ). For other resources and prospective structures described in Section 6 figures for field/resource size estimates are those provided by SOCAR. These are regarded as somewhat optimistic according to the industry view. The estimates of plateau production from such structures in this paper are low relative to estimates of reserves, reflecting the independent industry view, taking into account all the geological complexities of the fields/resources (high reservoir pressure and drilling challenges).
} 

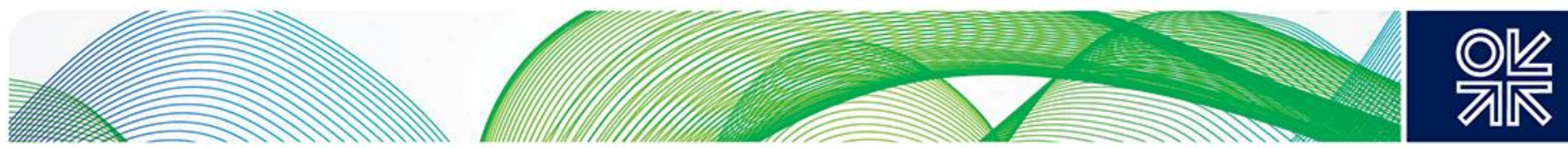

Figure 17: The Azeri-Chirag-Guneshli field

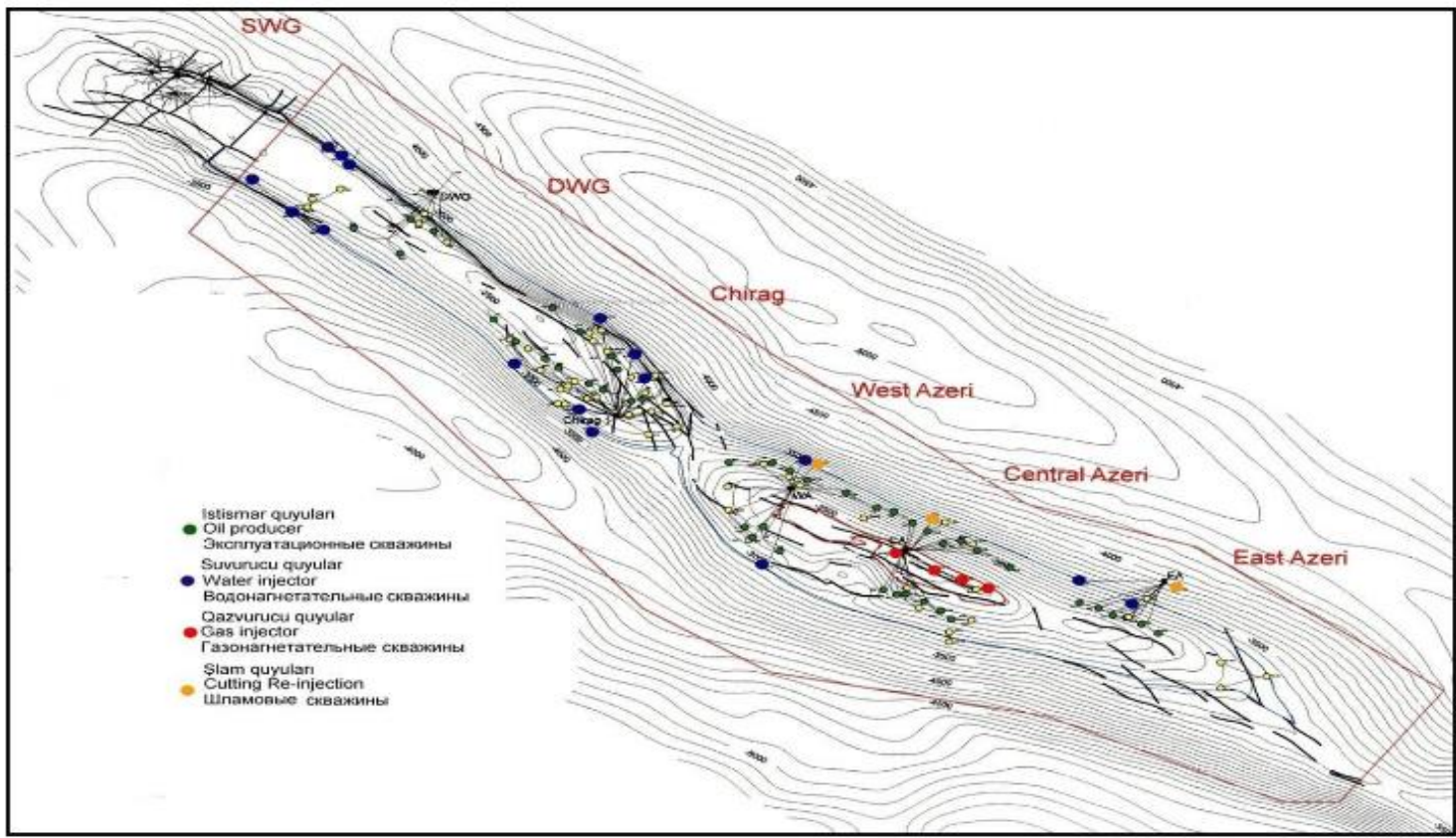

Source: SOCAR

If the second option is selected the decision on the further extension of the PSA will depend on the decision on the legal framework for the deeper layer of gas. Once the decision is made and the legal framework of the development is defined, the approximate timeframe for production of gas is 8 years (appraisal and development). A contractual/legal decision in 2015 would imply a potential development start date of 2019-2020 and first gas in 2027-2028. A reservoir of non-associated natural gas, estimated to contain some $280 \mathrm{bcm}^{92}$ of natural gas and 50 million tonnes of gas condensate is located below the oil deposits. Given the size of the field and its lifetime of approximately 25 years it is estimated that annual production will be approximately $4-5 \mathrm{bcm} / \mathrm{a}$ of natural gas.

\subsection{Summary}

The four fields/discoveries analyzed in this section are classified as commercial, or partially appraised. They may also contain a component of technical reserves (i.e. the reserves that are currently considered uneconomic to exploit), which may be due to a combination of factors such as development costs, low gas and oil prices, constraints in availability of equipment and facilities such as drilling rigs, vessels, etc., or gas reserves for which no commercial outlet is yet on the horizon. Furthermore, all four fields/discoveries are not yet appraised at lower depths, thus, creating uncertainties on possible gas volumes in deeper reservoirs.

Nevertheless, based on current estimates and assuming all key challenges are resolved, we can conclude that the gas production in the country by the end of the period (2021-2030) from the Group 1 commercial fields/discoveries (Absheron, ACG NAG Umid/Babek), may reach more than $15 \mathrm{bcm} / \mathrm{a}$ of gas (Figure 18). 

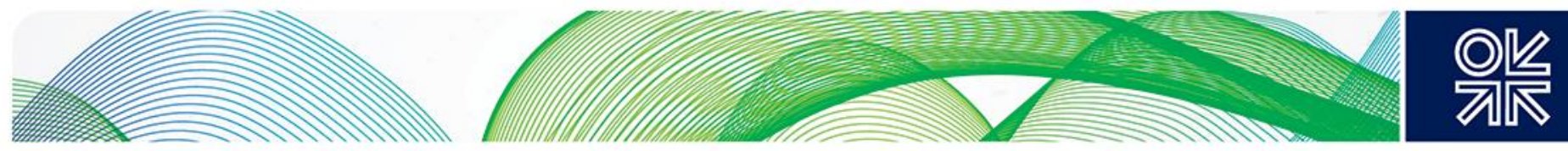

Figure 18: Gas production by key commercial fields

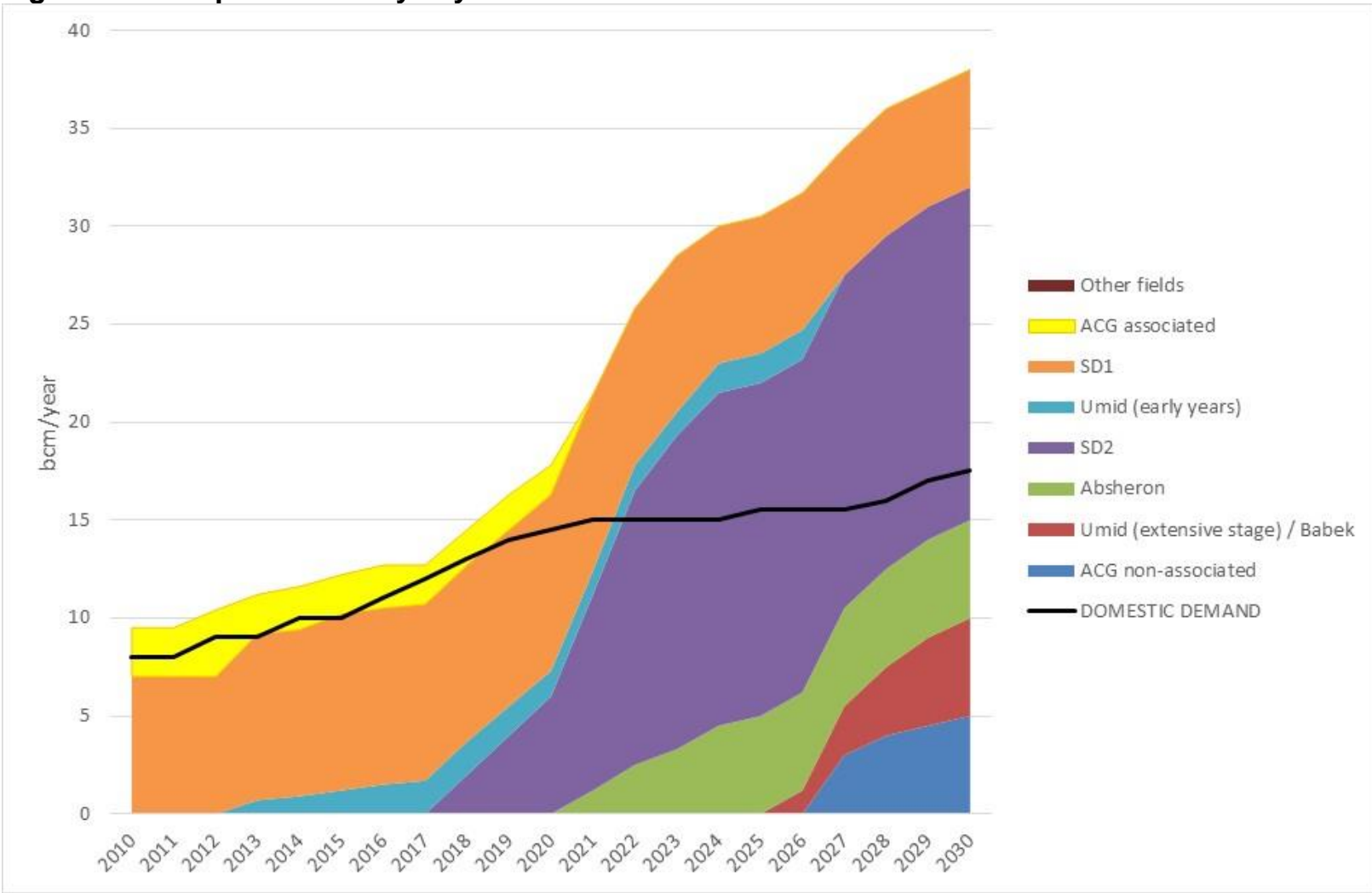

Source: Author's estimate

Figure 20 demonstrates future "free" uncontracted gas volume for export beyond SD2, plus existing export obligations and domestic demand, which is around $10 \mathrm{bcm} / \mathrm{a}$ and most likely to grow to no more than $15 \mathrm{bcm} / \mathrm{a}$ by 2030 . By 2022 with production of first gas coming from Absheron, the total gas production in the country would reach $35 \mathrm{bcm}$ (excluding associated gas and SOCAR's portfolio) and the uncontracted gas volumes available for new exports could be up to $15 \mathrm{bcm} / \mathrm{a}$ by the late 2020s from the fields shown in Figure 18. 

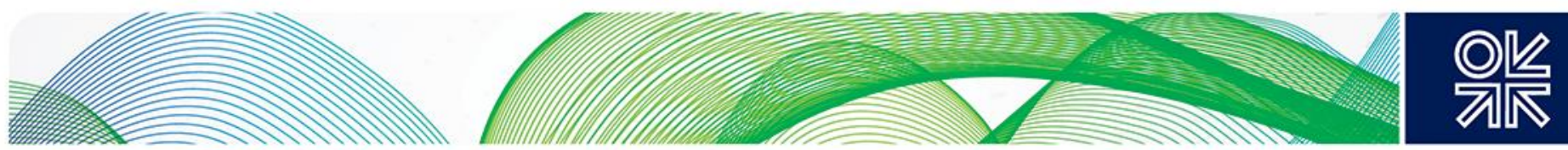

\section{Exploration Prospects: SD3, Nakhchivan, Shafag-Asiman, Zafar-Mashal, Garabagh, Inam, Alov-Araz-Sharg}

Azerbaijani geologists identified through seismic surveys a number of prospective structures in the Caspian Sea from the 1960s to the 1980s. These structures (which have not yet been the subject of exploration drilling, or where this has been done, the results were inconclusive) in the Azerbaijani sector of the Caspian Sea are SD3, Nakhchivan, Shafag-Asiman, Zafar-Mashal, Karabagh, AlovAraz-Sharg, and Inam. Some of these fields are shown on map 10 and 11. (For others, please refer to map 9 above).

\section{Map 11: Exploration prospects}

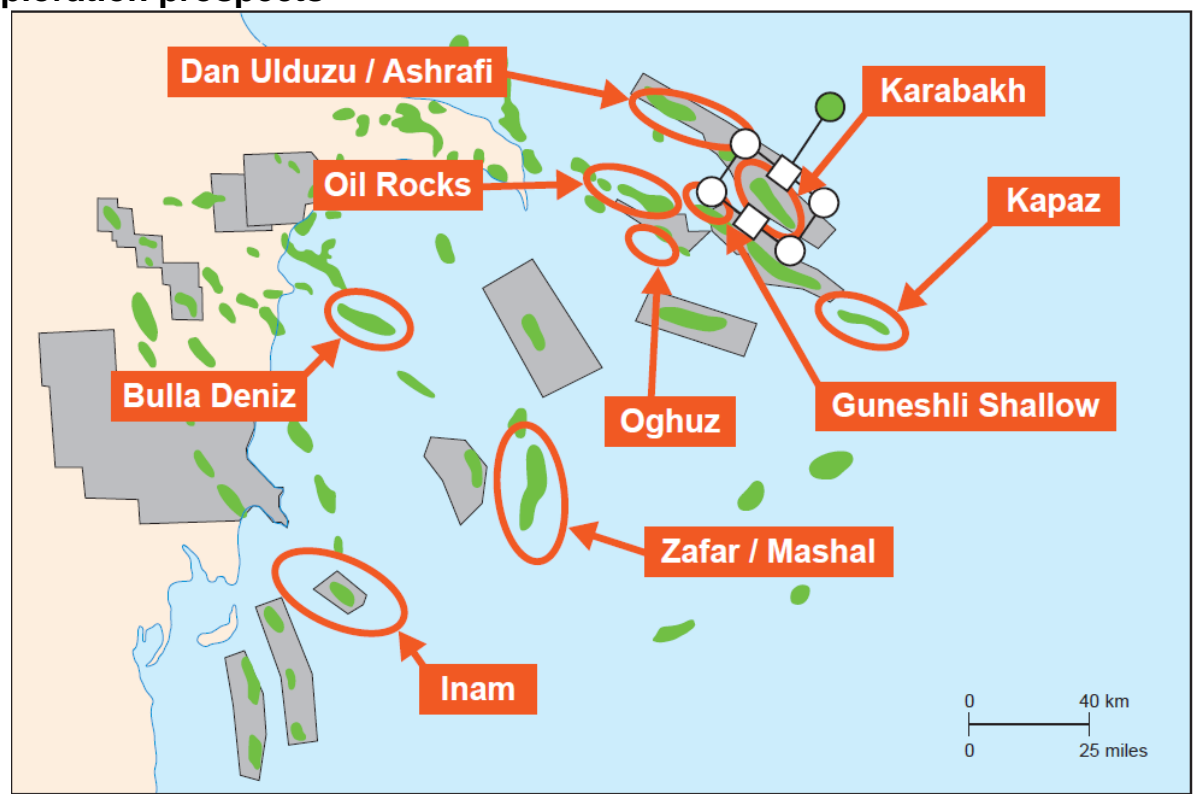

Source: OIES

In addition to the constraints of drilling rig availability some of these prospects suffer from other challenges such as high reservoir pressure and large pressure differentials between reservoir layers, potentially making them complex and potentially costly to develop. In addition to the geological risk that such prospects may not yield sufficient hydrocarbons to be commercially viable, technical drilling challenges as well as considerations of ultimate sales price and market requirements make it difficult to estimate the possible timing of future field development and hence production start. For that reason, all timings discussed below are indicative.

Similar to the Group 1 fields and prospective structures discussed in the previous section, the projection of the timing of first gas from Group 2 blocks is based on the analysis of the current status of a block, the motivation of the companies developing the block, availability of drilling rigs by the time it is decided to start exploration, and the addition of at least 11-12 years in total for the exploration, appraisal and development phases.

Seismic studies of all the exploration prospects have been completed and available estimates (in the event of a successful exploration well) of probable reserves were made based on these studies. In some structures at least, one well has been drilled with existing rigs, and as a result either were abandoned (considered as economically not profitable to pursue with development at given time, e.g. Zafar-Mashal), or yielded dry wells (Inam, Garabagh), or appeared to be technically and geologically challenging and costly (Nakhchivan). As a consequence, some of those fields have been relinquished by the consortia that began to explore them. 

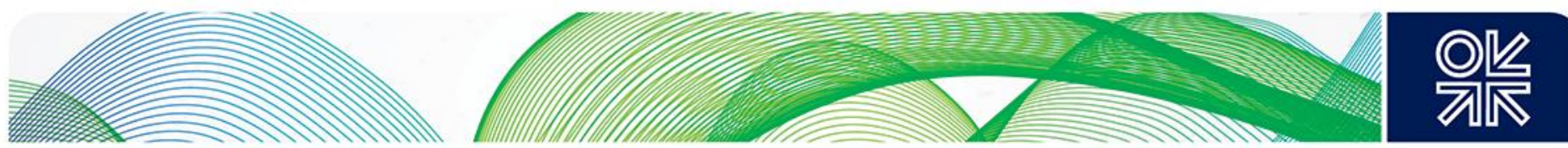

There are also structures with difficult political access, because of disputes about ownership with the Caspian littoral states such as Iran (Alov-Araz-Sharg) and Turkmenistan (Kapaz/Sardar). Apart from seismic study, no other work can be conducted in those areas, pending the resolution of differing territorial claims.

In accordance with the geological classification, these fields are classified as C2 (preliminary estimated), which recognizes reserves where wells have been drilled into the reservoir, but there are no firm exploration plans and total reservoir productivity is inferred, and C3, resources where prospects are identified and drillable, and hydrocarbon potential has been demonstrated (Table 6).

Almost all of the exploration prospects in the Azerbaijani sector of the Caspian Sea are licensed to companies that in many cases do not have a firm plan for appraisal or development. This however is certainly not helped by the rig availability situation.

Due to the difficult drilling conditions, a significant number of drilled offshore prospects have not been fully evaluated. As a result, some of the wells which did not originally prove up hydrocarbons, might yet prove to be successful if they are re-drilled and tested.

The remaining four commitment wells are at the Alov field. Work was halted in the Alov contract area in 2001 after two BP vessels undertaking geophysical surveys were forced back to Baku by an Iranian gunboat. Iran considers the Alov block to be partly located in its territory, and BP consequently put all block activities on hold until the legal status of the division of the Caspian is resolved. BP withdrew from the PSA in 2008. Indeed, this could open a window of opportunity for both Azerbaijan and Iran to find a mutually satisfactory solution. The summit in Astrakhan, Russia on September 292014 did not move forward the delimitation of the Caspian Sea between the littoral states.

Table 8: Awarded exploration prospects

\begin{tabular}{|c|c|c|c|}
\hline Year & $\begin{array}{l}\text { Contract } \\
\text { Area/Blocks }\end{array}$ & Companies & Country \\
\hline 1996 & Garabagh & Pennzenergy Co & U.S. \\
\hline 1997 & $\begin{array}{l}\text { Absheron } \\
\text { Nakhchivan } \\
\text { Dan Ulduzu-Ashrafi } \\
\text { Oguz contract area } \\
\text { Kapaz }\end{array}$ & $\begin{array}{l}\text { Chevron and TotalFinaElf } \\
\text { ExxonMobil } \\
\text { North Absheron } \\
\text { Mobil } \\
\text { Lukoil, Rosneft }\end{array}$ & $\begin{array}{l}\text { U.S., France } \\
\text { U.S } \\
\text { The consortium consisted of operator } \\
\text { BP ( } 30 \%) \text { and partners SOCAR ( } 20 \%) \text {, } \\
\text { Itochu (20\%), Unocal (25.5\%), Delta Oil } \\
\text { Company (4.5\%) } \\
\text { U.S. } \\
\text { Russia }\end{array}$ \\
\hline 1998 & Inam & BP & UK \\
\hline 1999 & $\begin{array}{l}\text { Alov } \\
\text { Zafar-Mashal }\end{array}$ & $\begin{array}{l}\text { BP,TPAO } \\
\text { SOCAR (50\%), Exxon (30\%), } \\
\text { Conoco }(20 \%)\end{array}$ & $\begin{array}{l}\text { UK, Turkey } \\
\text { Azerbaijan, U.S }\end{array}$ \\
\hline 2009 & Absheron & $\begin{array}{l}\text { Total returned to the block in } \\
\text { February } 2009, \text { GDF Suez, } \\
\text { took } 20 \% \text { equity from Total's } \\
\text { stake in June } 2009\end{array}$ & France \\
\hline 2010 & $\begin{array}{l}\text { Nakhchivan } \\
\text { Shafag-Asiman }\end{array}$ & $\begin{array}{l}\text { RWE signed a MoU with } \\
\text { SOCAR } \\
\text { BP }\end{array}$ & $\begin{array}{l}\text { Germany } \\
\text { U.K. }\end{array}$ \\
\hline 2013 & Zafar-Mashal & $\begin{array}{l}\text { Statoil signed a MoU with } \\
\text { SOCAR }\end{array}$ & Norway \\
\hline
\end{tabular}

Source: Author, companies' websites, various 

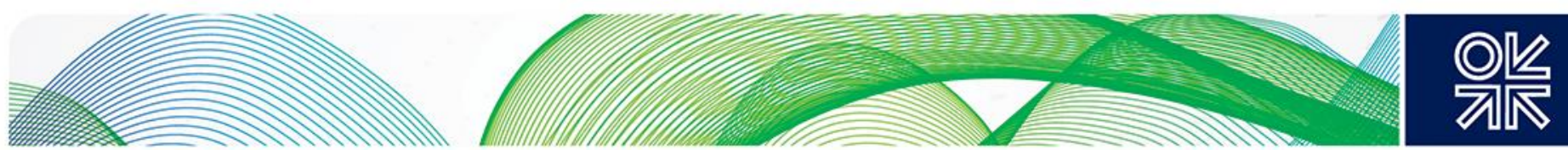

Figure 19: Foreign oil company blocks awarded and relinquished

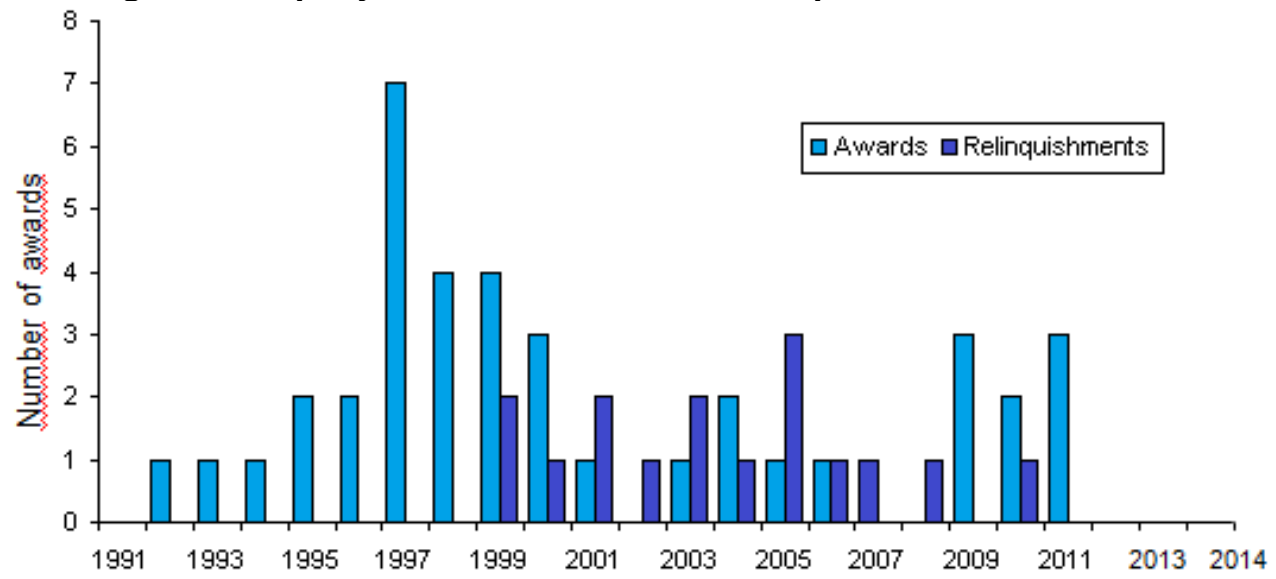

Source: Authors, public domain

All subsequent contracts have been concluded through direct negotiations with the national oil company, SOCAR. As shown in Figure 19, total licence awards were at a peak in 1997, when seven blocks were awarded (six PSAs and one Joint Venture). Since 1997, the number of awards has diminished and in 2013 and 2014 no licenses were awarded to the foreign majors. The total number of licenses awarded between 1991 and 2000 was 25. The number of awards decreased to 15 between 2001 and September 2014. The licenses awarded and relinquished relating to the blocks described in this section are listed in Table 8 and 9.

Table 9: Exploration blocks relinquished and participating companies

\begin{tabular}{|c|c|c|c|}
\hline Year & $\begin{array}{l}\text { Contract } \\
\text { Area/Bloc }\end{array}$ & Companies & Country \\
\hline 1999 & Garabagh & $\begin{array}{l}\text { Was relinquished by the } \\
\text { CIPCO consortium } \\
\text { (Pennzenergy, LUKoil and } \\
\text { Eni }\end{array}$ & U.S., Russia, Italy \\
\hline 2000 & Dan Ulduzu-Ashrafi & $\begin{array}{l}\text { The North Absheron } \\
\text { Operating Company (BP, } \\
\text { Unocal, Itochu, SOCAR, } \\
\text { Delta) relinquished }\end{array}$ & U.K., U.S., Azerbaijan, Japan, \\
\hline 2003 & Oguz & $\begin{array}{l}\text { relinquished by } \\
\text { ExxonMobil }\end{array}$ & U.S. \\
\hline 2005 & $\begin{array}{l}\text { Absheron } \\
\text { Nakhchivan }\end{array}$ & $\begin{array}{l}\text { Chevron relinquished } \\
\text { Exxon Mobil } \\
\text { relinquished }\end{array}$ & $\begin{array}{l}\text { U.S. } \\
\text { U.S. }\end{array}$ \\
\hline 2006 & Zafar-Mashal & Exxon relinquished & U.S. \\
\hline 2008 & Inam & BP relinquished & U.K. \\
\hline 2008 & Alov & BP relinquished ${ }^{93}$ & U.K. \\
\hline
\end{tabular}

Source: Author, companies' websites, industry media

${ }^{93}$ PSA is still in effect with TPAO 

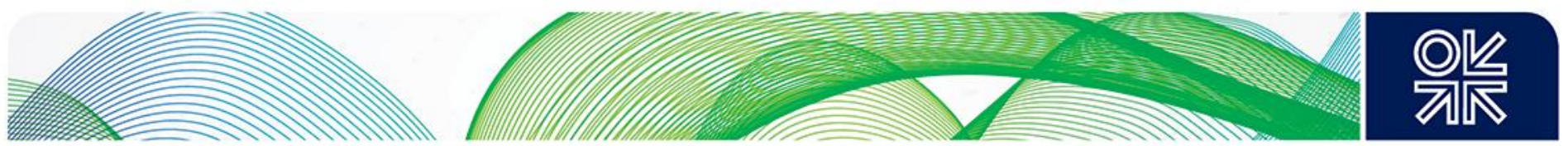

\subsection{Shah Deniz Phase 3}

The development of the third phase of the Shah Deniz field, which was discovered in 2007, seems to be more realistic and feasible than any other Group 2 blocks. This is because of the existence of a strong consortium which has been successfully functioning for almost two decades and, unlike other described blocks, the SD3 would not face uncertainties within the PSA nor any major misalignment of the partners with regards to future plans for exploration and development. The PSA has been extended and partners can legally develop the field till the end of 2048. We assume that it can be classified as a "Probable Development", with a greater chance of coming online by the early 2030s, than any other structures in Group 2.

For that reason, and because of the size of the field, the further development of the Shah Deniz field in Phase 3 should be considered a priority for both the government of Azerbaijan and the IOCs involved in the field. Given the size of the field reserves involved $(1.2 \mathrm{tcm})$, the gas production at the plateau level would likely be greater than any other contending blocks described in this section. Phase 3 development could be achieved with the help of subsea compression. This would require a special drilling rig, which would need to be a new-build. Given the timing of the exploration, appraisal and development stages (approx 11 years) and the timing of construction of a new rig capable of undertaking the subsea drilling, our assumption is that the possible timing of gas production from SD3 could be the early 2030s. Given the likely size of the SD reserves we assume that the annual production at the plateau level would be more than $10 \mathrm{bcm}$.

\subsection{The Nakhchivan Block}

The Nakhchivan contract area is located in 400-600 metres of water depth, some $90 \mathrm{~km}$ south of the Absheron Peninsula (Map 10), with a contract area of 850 square $\mathrm{km}$ and a water depth of $120-750$ metres. It was first discovered by Azerbaijani oil explorers in 1960 and prepared for drilling in 1994. According to the conducted seismic study, the preliminary estimate shows that the probable gas reserves of the block are up to $300 \mathrm{bcm}$ of natural gas and 40 million tonnes of gas condensate ${ }^{94}$. The potential gas production is $2-4 \mathrm{bcm} / \mathrm{a}$.

RWE Dea AG, the upstream division of RWE Group, signed a MOU with SOCAR in 2010 "On coordination of key commercial principles and conditions of exploration, development and production sharing from prospective structure Nakhchivan"95. The Heads of the Agreement were signed in 2011. However, the final PSA is still outstanding because RWE Group decided to sell RWE Dea ${ }^{96}$. As soon as the sale process is completed, the new owner will be able to follow up on the process of PSA signing.

Given the current development status of the Nakhchivan block, with no PSA agreement on development thus far, and also its complex geological structure, high pressure in the hydrocarbon reservoir, as well as the possible high development cost and most importantly scarcity of drilling rigs it is generally assumed that the gas from this structure may come on stream in the early 2030s. RWE and SOCAR do not have a defined work programme and development plan, as little work has been done since the MOU was signed. Given at least 11 years for exploration, appraisal and development, we predict that exploration works might start in 2022 with first gas extracted in 2033. This is when the first gas from Absheron would come on-stream and a semi-submersible drilling rig could be freed up.

\footnotetext{
94“"RWE: Developing perspective offshore Nakhchivan field in Azerbaijan to contribute to Nabucco project”, http://www.today.az/news/business/63628.html, 10 April 2010

95 The Memorandum of Understanding

96"Germany approves RWE Dea sale”, http://www.offshoreenergytoday.com/germany-approves-rwe-dea-sale/, 22 August 2014
} 

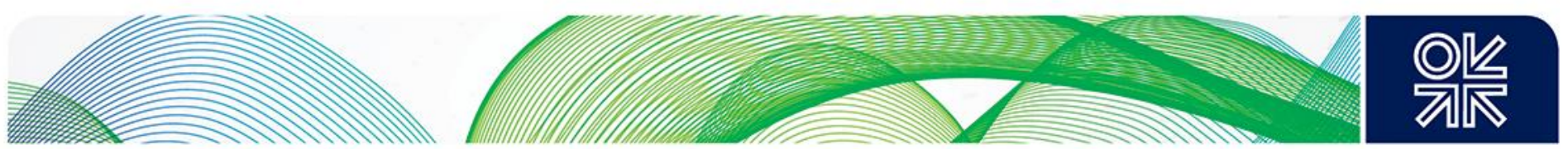

The timing of production will also depend on the PSA to be signed; the price for gas in the targeted market by the time development works start, hypothetically in 2028; availability of buyers; and capacity in existing transportation infrastructure.

\subsection{The Shafag-Asiman block}

The Shafag and Asiman structures are located 125 kilometres to the southeast of Baku (Map 10). The contract area covers $1,000 \mathrm{~km}^{2}$, at a water depth of $650-800 \mathrm{~m}$ with the depth of the reservoir at 7,000 metres. The Shafag and Asiman structures have been previously called D8 and D10, respectively.

The MOU between SOCAR and BP covering this area was signed in July 2009 and the PSA on joint exploration and development for a period of 30 years (with potential extension of up to 5 more years) in October 2010. It was agreed that the exploration period would be 4 years with possible prolongation for another 3 years. The first stage of exploration works envisages the drilling of two wells. The second stage assumes drilling of two more wells, if necessary. If and when the participants move to the production stage, they have agreed to operate the project jointly. The two companies hold equal interests in the project.

With a size of 1,000 square $\mathrm{km}$, this is the third largest concession to be awarded to date in the country. This block has never been explored previously. The initial estimates put the probable reserves at between 350 and $500 \mathrm{bcm}$ of natural gas and 65 million tonnes of condensate. The potential annual gas production is estimated to be 4-6 bcm. 2-D and 3-D seismic studies have been performed by Caspian Geophysical under the BP contract in 2011 and 2012. And the third data interpretation phase was completed in the first half of 2014.

To date, no exploration wells have been drilled, and it is expected that the exploration stage alone could take from 4 to 7 years. Given the current development status of the block we can assume that the first gas could come on stream no earlier than the mid 2030s.

\subsection{The Araz -Alov- Sharg block}

The Araz-Alov-Sharg contract area is located in 300-1,000 metres of water depth, some $120 \mathrm{~km}$ southeast of Baku (Figure 20). With an area of 1,400 square kilometres, it is the second largest offshore concession to be awarded to date in Azerbaijan. It contains three prospects - Alov, Araz and Sharg. Ownership of all three prospects is disputed by Iran (Araz-Alov-Sharg), which makes any exploration and development works impossible at this stage. Such work programmes are postponed until such time that the Caspian Sea basin is delimited between the littoral states. Potential gas reserves are estimated at $700 \mathrm{bcm}$ of natural gas and 90 million tonnes of gas condensate with possible annual production up to $8 \mathrm{bcm}$. 

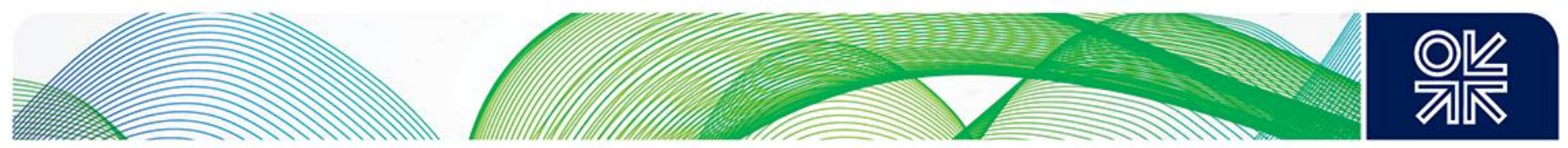

Figure 20: Alov Seabed

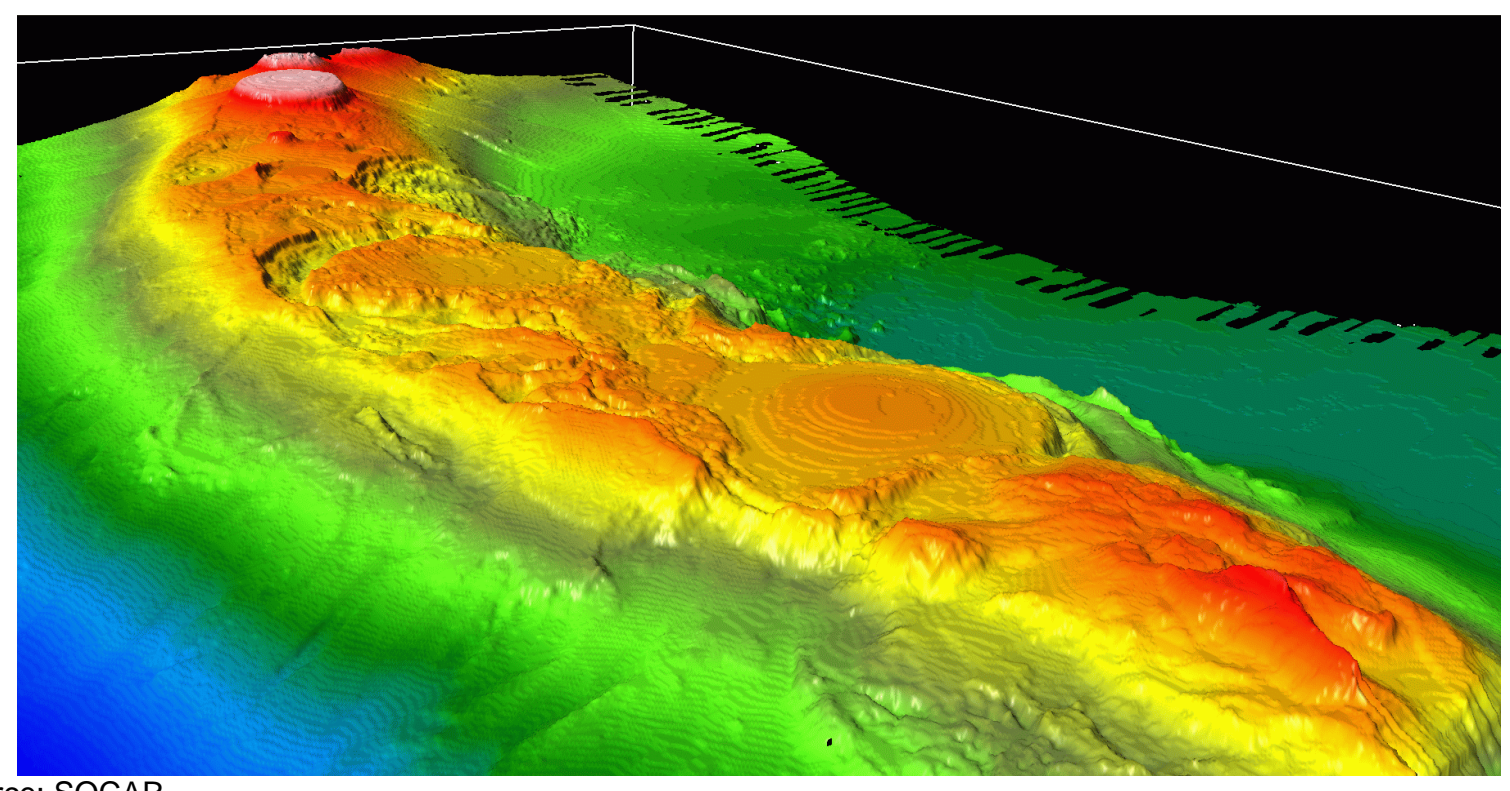

Source: SOCAR

The 15 year PSA for exploration and development was signed by the shareholders comprising BP (15\%), Statoil (15\%), TPAO (10\%), SOCAR (40\%), ExxonMobil (15\%) and EnCana Corporation (5\%), with BP as operator. However, the contract has not been extended due to the structure's disputed status.

Prospective reservoir sections have been interpreted in the Upper and Lower Productive Sequence at depths ranging between 2,500 and 6,500 metres. The Surakhany Suite may prove to be the most prospective horizon, although both plays are considered equally important by BP. The phase content of the prospects remains uncertain at this stage with no nearby well control. With multiple prospects and plays, and uncertain phase outcomes, reserve estimates cover a wide range.

On July 23 2001 , two BP vessels which were undertaking shallow geophysical and research scientific surveys on the Alov contract area were forced back to Baku by an Iranian gunboat. Iran considers the Alov block to be partly located in its territory. BP consequently decided to continue technical studies but not to return to the location until the legal status of the Caspian is resolved. Given this, it is uncertain when the partners may start exploration works, thus making the possible gas production timing absolutely indefinite.

\subsection{The Zafar-Mashal block}

The Zafar-Mashal deepwater block contract area is located some $110 \mathrm{~km}$ southeast of Baku, close to the SD field (Map 10) in water depths ranging from about 550 to $900 \mathrm{~m}$ and covers about 640 square $\mathrm{km}$. There is a sea depth of $618 \mathrm{~m}$ in the area of the first exploration well. Potential gas reserves are estimated at $300 \mathrm{bcm}$ of natural gas and 37 million tonnes of gas condensate with possible annual production of 2-3 bcm.

The "Zafar-Mashal" structure was discovered as a result of seismic research in 1961 and the first geophysical works were conducted in 1965 and 1987. Exploration drilling has not been carried out.

The first contract for the development of this prospective structure was signed by SOCAR and ExxonMobil on April 27, 1999. SOCAR had a 50\% stake in the project, ExxonMobil $30 \%$ and ConocoPhillips 20\%. In 2004 Exxon contracted Maersk of Denmark to drill the Zafar-1 well, which was conducted from the semisubmersible drilling rig "Leader" (now Heydar Aliyev). The main goal of the 

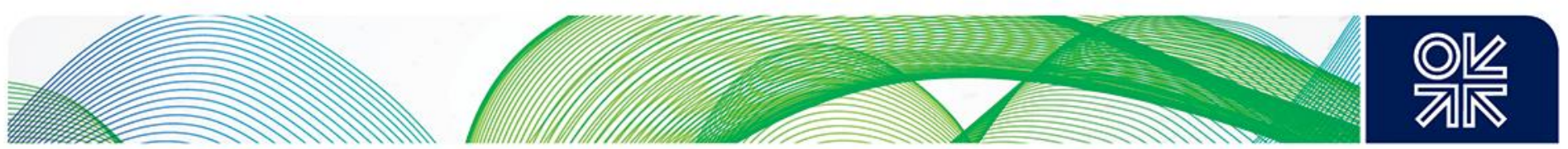

drilling was the formation and VIII Horison of the "Balakhan Formation". However, the drilling did not show positive results. As a result, the project was ended because the discovered hydrocarbon volumes were non-commercial and the well was plugged and abandoned in 2006.

The first exploration well on the structure involved complex drilling due to the varying water depth (sloping sea bed), high reservoir pressure, presence of mud volcanos and gas accumulations at shallow depths.

In April 2013, Statoil signed a MOU with SOCAR on joint exploration and development, which set out the basic commercial principles and conditions of the PSA contract to be signed in the future ${ }^{97}$. Given the recent $\mathrm{MOU}$ signing and lack of a PSC, our assumption of the timing of first gas is no sooner than after the mid 2030s.

\subsection{The Inam Block}

The offshore Inam Contract Area covers 225 square $\mathrm{km}$ and is located approximately $140 \mathrm{~km}$ south of Baku (Map 11). The probable gas reserves are estimated at $100 \mathrm{bcm}$ of natural gas and 1.4 million tonnes of gas condensate.

A PSA for 25 years (that may be extended for another 5 years), ratified by Azerbaijan's Milli Majlis (Parliament) in December 1998, gives exploration, development and production rights to a BPoperated consortium made up of BP $(25 \%)$, the Korea National Oil Company (KNOC $-20 \%$ ), Shell $(5 \%)$ and the SOCAR Oil Affiliate (SOA - 50\%). The PSA states that BP and its partners are required to collect seismic survey data for the whole Contract Area and to drill two wells during the Exploration Phase of the PSA.

The Inam structure was drilled by SOCAR in the early 1990s but the well was halted when it encountered very high pressures. In 1999 an extensive 3-dimensional seismic survey was acquired over the structure. In 2000/2001 the consortium drilled the INX-1 well on the southern flank of the structure with the Dada Gorgud rig. This well also encountered extremely high pressures as it reached its target depth. Data from these two wells combined with results from other South Caspian exploration wells were interpreted and have led to a plan to drill the INX-2 well on the Inam structure with the Istiglal rig. The INX-2 well design has incorporated lessons from all these previous wells and some of the latest technologies in drilling in order to successfully evaluate the potential of the Inam structure. Currently all the drilling works are on hold because no rig is available.

\subsection{The Garabagh block}

The Garabagh oil and gas block is located $130 \mathrm{~km}$ east of Baku, in the northern part of the Absheron archipelago (Map 11) with a target potential reservoir strata depth of 3,300-4,200 metres. According to preliminary estimates the block may be the second major contract for oil field development in the Caspian Sea after the ACG project, with a probable 650 million tonnes of oil and probable $20 \mathrm{bcm}$ of natural gas. The possible annual gas production may be up to $1 \mathrm{bcm}$.

The PSA with the Caspian International Petroleum Company (CIPCO) which included LukAgip JV $(45 \%)$, Pennzoil (30\%), Lukoil (12.5\%), SOCAR (7.5\%), Agip (5\%) was signed for 25 years in November 1995 and ratified by the Milli Majlis in February 1996. In 1998 CIPCO drilled an exploration well, KPS 2, with the Dada Gorgud rig. However the result was not encouraging and in January 1999, CIPCO announced it would cease its operations. According to the consortium, the development of the

\footnotetext{
97 "Statoil and SOCAR sign MoU to explore new Caspian acreage", Statoil, 8 April 2013, http://www.statoil.com/en/NewsAndMedia/News/2013/Pages/08Apr Azerbaijan.aspx
} 

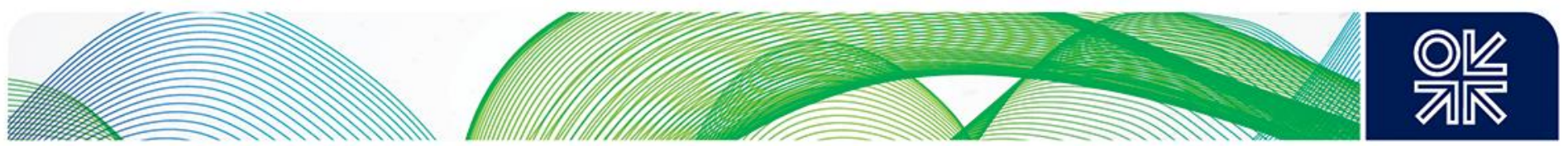

field was not economically profitable with the low oil price at the time. Since the relinquishment of the block, possible partners to develop the structure with SOCAR have not so far been identified.

\subsection{Summary}

While analyzing the current development status of the exploration prospects, one can conclude that there is a great uncertainty with the possible reserves and development timing because of:

- so-called dry wells (Inam, Garabagh);

- areas that are uneconomic to develop further at this stage (Zafar-Mashal and Garabagh);

- areas with high reservoir pressure and complex geology (Nakhchivan, Inam);

- difficult political environment (Araz-Alov-Sharg, Kapaz/Sardar).

Following a number of disappointing wells, the south Caspian Sea remains under-explored and considerable potential for the large hydrocarbon accumulations exist, especially in the Azerbaijani sector. Further exploration drilling on the prospective structures may yield more encouraging results, proving-up the existing estimates of gas resource potential.

However, the availability of the foreign companies willing to take the financial risks and invest in exploration wells having no firm knowledge of the possible gas reserves of the target reservoir structures is important. This is the case especially for the prospects from which companies have withdrawn (and the consortia involved have legally relinquished their positions). Once the companies' calculations of the commerciality of the reservoir are confirmed, and the market gas price outlook is favorable, companies may pursue further appraisal drilling. The development stage of the prospective structure is very much dependent on the availability of buyers and market.

No less important is the availability of capacity in the infrastructure to transport any potential natural gas. This would need to be addressed after the problems with drilling rigs and other equipment are resolved. Having said that, there are clearly challenges to be overcome before first gas could be achieved for Group 2 fields.

This is probably not the case for Shah Deniz Phase 3 as the consortium has secured buyers for SD2 volumes for 25 years from 2020. We assume that the most likely new gas volumes that can come online within the Phase 2 production in Azerbaijan and among the Group 2 fields is SD3 with probable annual production more than $10 \mathrm{bcm}$ at the plateau level.

Nevertheless, for identifying the total "surplus" of uncommitted natural gas possibly available from the Group 2 prospects, we have calculated the probable annual production (based on the size and lifetime of the prospective structure). We assume that the overall natural gas volumes to be available for export in the 2030s from the Group 2 exploration prospects could reach more than $20 \mathrm{bcm} / \mathrm{a}$ (Figure 21), including SD3 gas and excluding some $8 \mathrm{bcm} / \mathrm{a}$ of gas from Araz-Alov-Sharg as well as SOCAR's gas production from its current portfolio. Because this block is disputed between Iran and Azerbaijan, it is uncertain when and how this problem will be resolved. This could be achieved either by the delimitation of the seabed of the Caspian Sea, or by mutual agreement of both sides to explore and develop the block jointly. As this is uncertain at the moment, this makes the timing of the production from Araz-Alov-Sharg indefinite. 

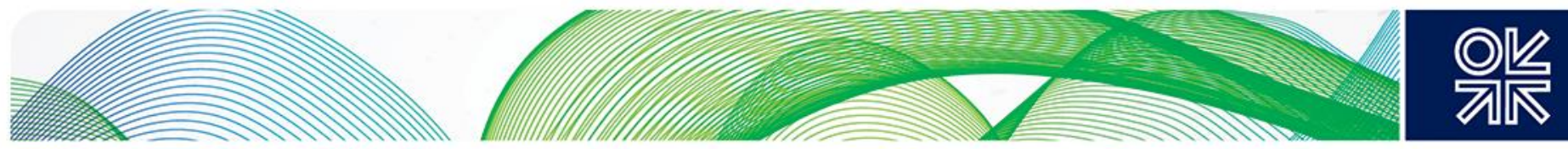

Figure 21: Potential gas production in the 2020s and 2030s

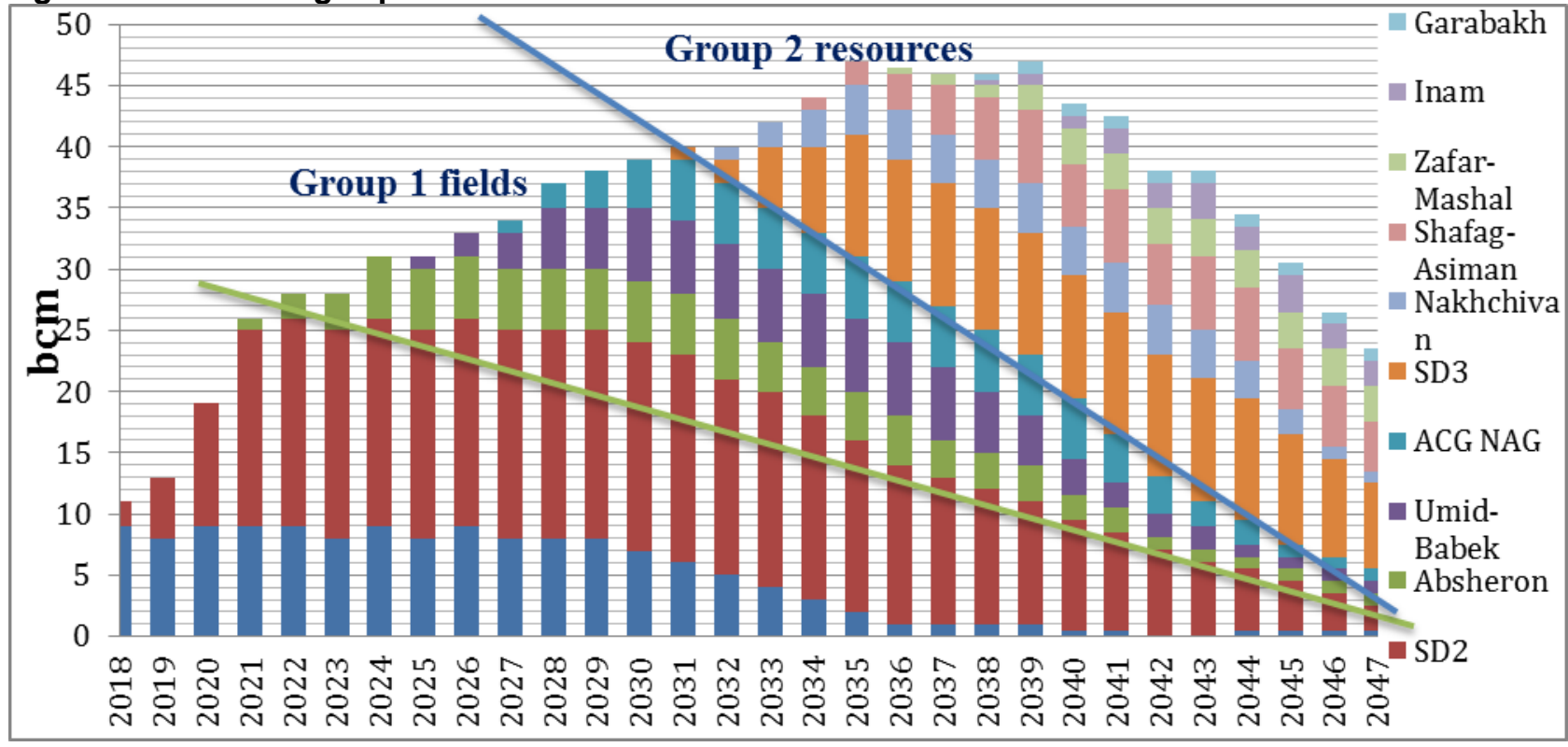

Source: Author's estimates

It is projected that the Azerbaijan domestic demand will not grow to more than $15 \mathrm{bcm} / \mathrm{a}$ in the $2020 \mathrm{~s}$ from the current level of around $10 \mathrm{bcm} / \mathrm{a}$, for the reasons described in Section 3. Any attempts to predict the domestic demand in the 2030s would only be indicative. Given the government's long-term plans to develop non-oil sector industry and reduce dependence on oil revenues, population growth and new urban construction, natural gas demand may grow more rapidly within the projected period. However, domestic investment in non-oil projects will depend on many macro-economic developments and primarily the oil price. Having said that, we assume that by the end of the 2030s demand will not grow to more than $20 \mathrm{bcm} / \mathrm{a}$ in a high case scenario.

This gas would be covered from the SOCAR share in SD (16.7\%), associated gas from oil fields as well as from the SOCAR share in the fields of Group 1 (Absheron, Umid/Babek, ACG NAG) in accordance with the PSAs. If and when these projects come on stream, SOCAR may sell gas in the domestic market from its share in the Group 2 fields, thus potentially reducing the possible export volumes by $20 \mathrm{bcm} / \mathrm{a}$. It is impossible to accurately estimate SOCAR's PSA share of gas production from PSAs in future years as this is a calculation based on cost recovery and profit shares of production. 

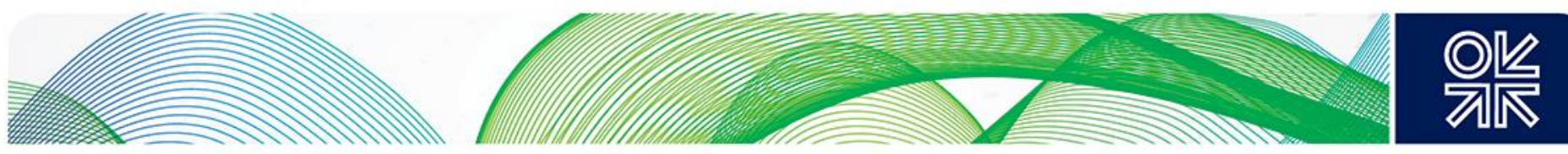

\section{Possible Marketing Arrangements for and Transportation of Un- contracted gas}

Perhaps the section on the possible marketing arrangements for the next wave of natural gas production and its transportation is the most important one. Without such an arrangement none of companies will invest in field developments and thus no gas can be produced. Also, without a secured market, the possible gas developments described in the previous sections of this paper may not be viable. Prior to field development, therefore, significant efforts are being devoted to gas marketing arrangements, from investigating market potential, identifying potential buyers, negotiating pricing structure and other commercial terms and ultimately concluding Gas Sale and Purchase Agreements with buyers.

\subsection{Marketing}

There are three possible forms of marketing arrangement for gas sourced in Azerbaijan that could be used by companies developing fields and blocks:

- the first scenario is selling gas 'field by field';

- the second scenario is the creation of an Azerbaijani gas portfolio, a 'virtual pool', which all the country's gas effectively flows into, and

- the third form of marketing involves each company developing a structure in which it would sell its share of gas separately on its own (to the market it considers suitable, without the prior consent of other shareholders). In the context of Azerbaijan, this form of arrangement is not really feasible as it would result in different netbacks between field participants and make the process of gas marketing difficult to co-ordinate. Obviously, project FID cannot be achieved unless all the partners have finalized their marketing arrangements. For that reason, this type of marketing is not considered further in this paper.

The field by field type of marketing is an arrangement when the gas is sold via the marketing company of the field, in which the shareholders are the companies developing the upstream project (the case of Shah Deniz). The upstream companies may or may not have the same shares in such a marketing company as in an upstream project.

The first phase of the Shah Deniz project saw the establishment of a marketing company, Azerbaijan Gas Supply Company (AGSC). The same approach (the sale of gas to the marketing company, in which the upstream co-ventures have shares, aggregation of gas volumes and the joint sale to buyers) will be adopted for Shah Deniz Phase Two volumes. However, this form of marketing cannot work if, for instance, the Absheron shareholders decide to sell the gas to European buyers and if the EC will not grant an exception to sell it jointly. In this case the individual sales approach will be necessary, albeit with firm requirements for co-ordination such that project viability and schedule are not threatened.

With the Absheron field the following scenario is also possible: SOCAR can buy out all the gas available for export from the Absheron consortium at a price which gives greater than a defined minimum net back (based on a Turkish or European market reference price) and add it to its own gas portfolio. In this case, the margin for the shareholders would be safeguarded and the risks of transportation and marketing would be minimized.

In the event that the shareholders decided to sell the gas jointly to, for instance, the Turkish market, the marketing of gas from each of these fields would be realized with different terms and conditions, pricing models, volumes, etc. This model is less risky for SOCAR, as all the risks would be shared 

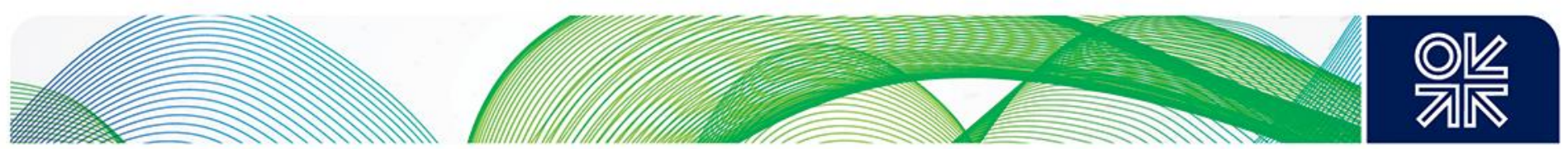

among partners equally, but probably not optimal in terms of efficient volume management from the perspective of the Azerbaijani government. IOCs would participate in the whole value chain and share risks.

The second form of arrangement is to create one single entity for all the volumes from the so-called next generation gas fields. This would constitute an Azerbaijan/SOCAR gas portfolio where SOCAR or an affiliated company would undertake the marketing of gas of Azerbaijani origin (and possibly other gas in the future) as a single entity. For example, the Republic of Azerbaijan represented by SOCAR or a SOCAR-affiliated company could buy all future field development gas from the IOCs at a certain delivery point, and conduct the sale as a single entity, to European (and any other potential) buyers. The advantages for SOCAR and IOCs of such marketing arrangement would be:

- $\quad$ SOCAR or a SOCAR-affiliated company would be able to market gas in a more flexible manner (including globally, in the form of LNG if viable);

- $\quad$ it could mitigate demand variations of individual buyers by using a portfolio approach with different supply sources and multiple buyers in different countries;

- IOCs could significantly reduce their risks, because they would neither have to participate in the marketing nor the sales process.

Certainly this type of marketing would need to be agreed with IOCs. It could be suitable for those companies that would not wish to participate in all the segments of the value chain, such as transportation, defining the suitable market, finding potential buyers. In this case, those companies would not have to have a share in the transportation infrastructure. For instance, Total divested from SD (upstream) and SCP (midstream) projects. It would not have to reinvest in SCPx and/or SCPfx in order to transport its gas from the Absheron field to any potential market. However, this form of marketing would not be possible if IOCs had a strong desire to participate in transportation and marketing of their own gas.

\subsection{Infrastructure capacity}

The availability of pipeline capacity is an important factor for companies at the pre-FID stage. Before taking any decision on investing in the development of a field, the partners must secure capacity in pipelines to transport the gas to a market. For instance, RWE Dea which is planning to sign a PSA with SOCAR on the exploration and production of the Nakhchivan structure is unlikely to start investing in exploration of the structure now, even if a rig is available, if there are uncertainties with the future expansion of SCP (SCPfx) and further future expansion (SCPffx). SCPfx is designed for the volumes potentially coming from the commercial fields - Absheron, Umid/Babek, ACG Deep in 2020s and potential structures in the 2030s. The following sections describe the potential stages of expansion of the export transportation system from Azerbaijan to Turkey and European markets. Given the inherent uncertainties on timing and plateau production from future upstream developments this is by necessity an illustrative scenario based on current estimates. It is nevertheless useful in surfacing the key decision points to be addressed as export volumes of Azerbaijani gas increase.

\subsubsection{South Caucasus Pipeline}

SCP is a $692 \mathrm{~km}$ pipeline, designed to transport $8 \mathrm{bcm} / \mathrm{a}$ of gas from SD1 to the Georgian and Turkish markets, also to the domestic market in Azerbaijan. The pipeline is currently being expanded for an additional capacity of up to $17 \mathrm{bcm} / \mathrm{a}$, for the natural gas coming from the SD Phase 2 in late 2018/2019. 

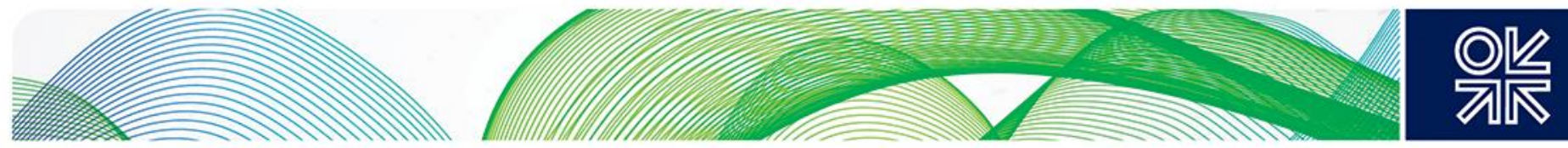

\section{Map 12: South Caucasus Pipeline expansion}

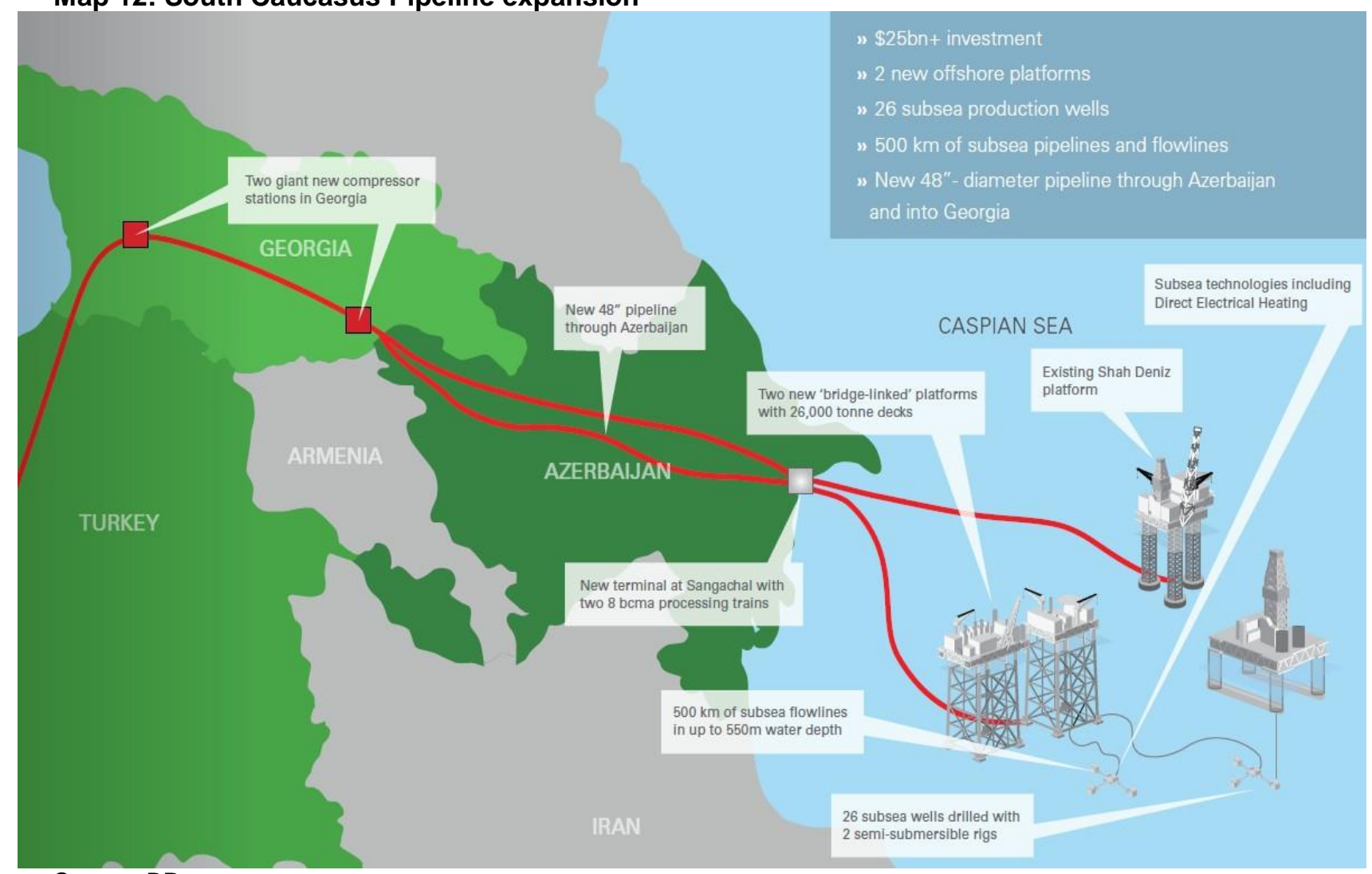

Source: BP

It is planned that the expansion will be achieved through the construction of a parallel 1,422-millimetre pipeline (48 inch), with an overall length of $387 \mathrm{~km}^{98}$ (Map 12).

The construction of a $387 \mathrm{~km}$ pipeline loop and associated above ground installations, including: block valves, a pigging facility and tie-ins in Azerbaijan and Georgia and construction of a $59 \mathrm{~km}$ second pipeline loop and associated above ground installations in Georgia will cost $\$ 735$ million ${ }^{99}$. The contract for pipeline construction in Azerbaijan and Georgia has been awarded to Saipem/Azfen, which is a joint venture between Saipem Contracting Netherlands BV and Azfen JV. This will expand capacity to $17.6 \mathrm{bcm} / \mathrm{a}$ of natural gas.

Based on the conclusions in Section 5, the additional gas volumes projected to come on-stream in the 2020 s from the Group 1 fields are estimated at over $15 \mathrm{bcm} / \mathrm{a}$. In order to achieve the FID for field development, partners developing Absheron and other fields/structures will have to ensure the availability of capacity in SCP.

\footnotetext{
98" Expansion of SCP pipeline to transport Shah Deniz gas to end in 2018”, Azernews, http://www.azernews.az/oil and gas/50786.html, 13 March 2013

99"South Caucasus Pipeline Expansion Contract Awarded", Offshore Energy Today,

http://www.offshoreenergytoday.com/south-caucasus-pipeline-expansion-contract-awarded/, 26 May 2014
} 

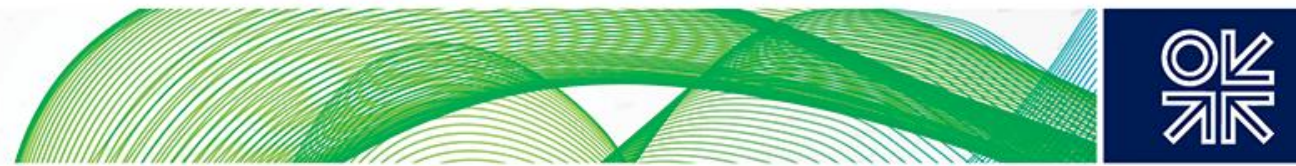

Figure 22: Volumes (bcm/a) vs SCP capacity

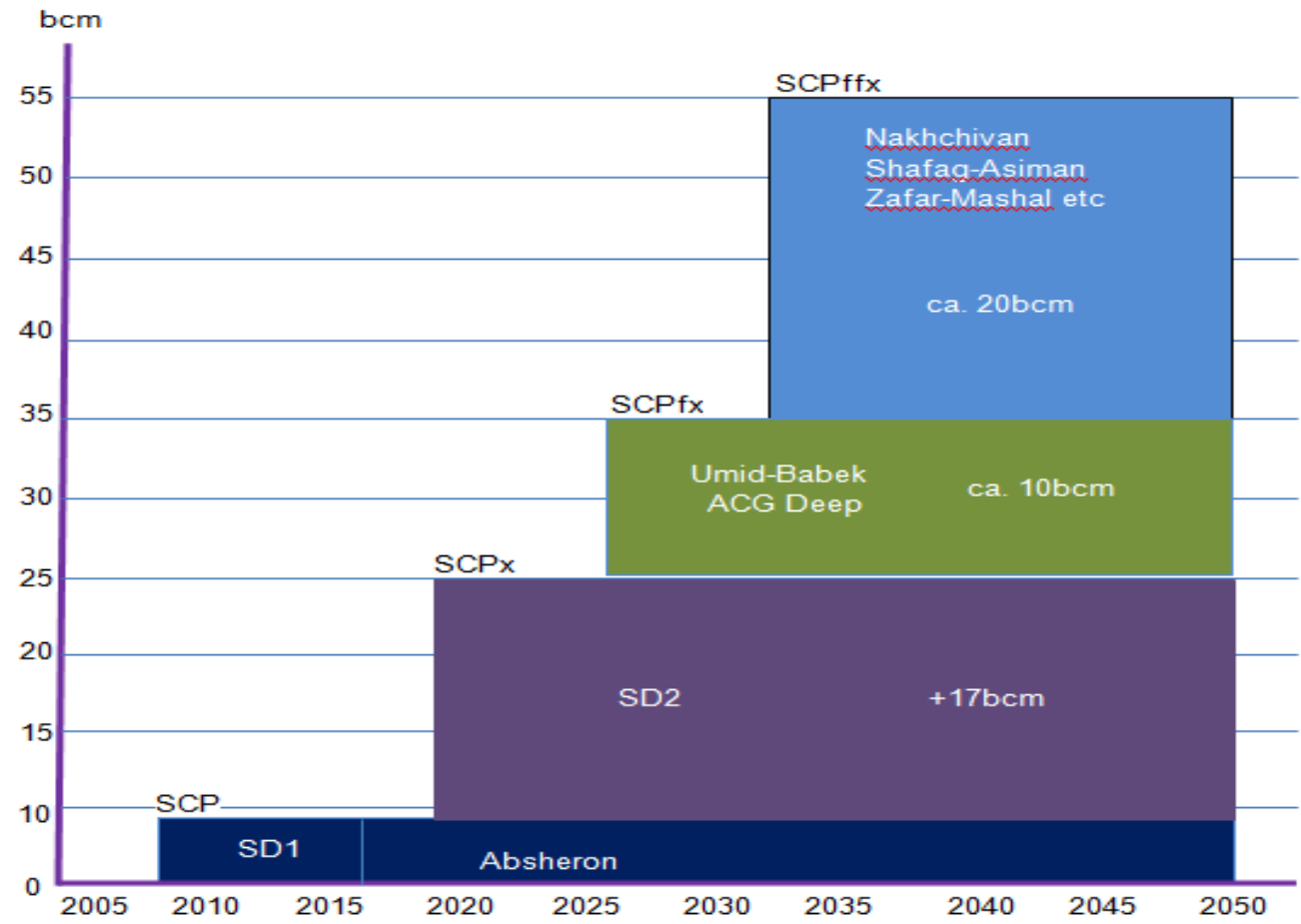

Source: Author's estimate

Future expansion, however, will be needed to transport some $8-11 \mathrm{bcm} / \mathrm{a}$, that would be produced starting in the late 2020s: 4-6 bcm/a from Umid/Babek and 4-5 bcm from ACG deep gas. SCPfx is planned to be achieved by adding compressor stations in Azerbaijan and Georgia and/or looping by 2026-27, when gas from Umid/Babek, according to our estimates, will come on-stream followed by the ACG deep reservoir gas in 2027-28 (Figure 22).

Although we have indicated the next stage of expansion of the pipeline in Figure 24 and conditionally named it further future expansion of SCP (SCPffx), there is no defined plan for this expansion of the pipeline at present. This would be addressed when the partners have a clear plan to start developing the blocks and the exploration structures by the 2030s, which could result in the production of a potential $20 \mathrm{bcm} / \mathrm{a}$ of incremental gas. The decision to develop SD Phase 3, the Nakhchivan structure and other exploration blocks would also depend on the availability of necessary capacity in the export infrastructure.

According to our assumptions, the first gas potentially to be produced from the Group 2 structures could be in the early 2030s, and is likely to be SD Phase 3 with probable annual production of around $10 \mathrm{bcm} / \mathrm{a}$. This means that by 2031-32 an additional minimum ramp up volume of 2-3 bcm/a of capacity will be needed in SCPfx that can be added with additional compressor stations. The next volumes could come presumably from Nakhchivan and Shafag-Asiman. This could come on-stream 2 years later by the mid 2030s, which will need additional ca. 6-8 bcm/a of annual export capacity. The construction of a third SCP line for the third expansion stage (SCPffx) may be needed to transport potentially more than $20 \mathrm{bcm} / \mathrm{a}$ of natural gas from Group 2 structures by the late 2030s, when gas production in Azerbaijan is likely to achieve its peak level (Figure 22). 

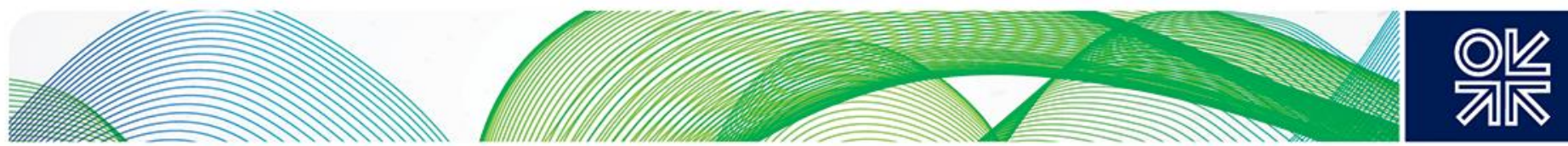

\subsubsection{Trans-Anatolian Pipeline (TANAP)}

The TANAP pipeline is planned to be connected to SCP on the Turkish-Georgian border (Türkgözü), terminating at the Turkish-Greek border (Ipsala-Edirne). The 1,804 km pipeline is planned to have a 56-inch diameter onshore $(1,333 \mathrm{~km}), 48$-inch from the Eskişehir off-take point up to the TurkishGreek border $(458 \mathrm{~km})$ and 36 -inch (dual line) for the sub-sea section $(19 \mathrm{~km})$, with 7 compressor stations at $31 \mathrm{bcm} / \mathrm{a}$ full capacity. As shown in Map 13, there are two offtake stations in Turkish territory - Eskişehir and Çanakkale.

\section{Map 13: TANAP compressor stations}

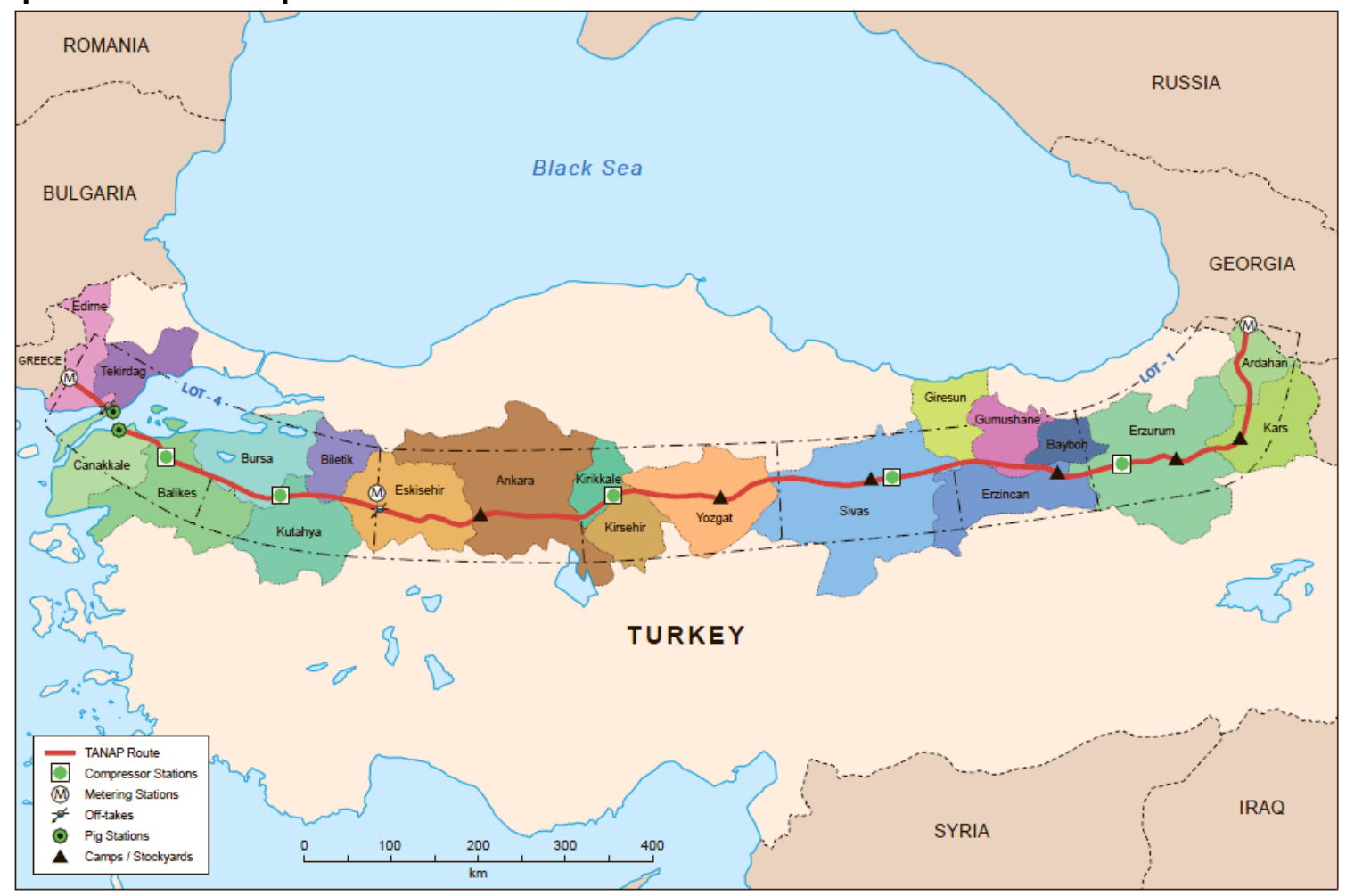

Source: OIES, TANAP

As shown in Figure 23, it is planned to expand the pipeline in three stages with initial capacity of up to $17 \mathrm{bcm} / \mathrm{a}$ for SD Stage 2, of which $5.7 \mathrm{bcm} / \mathrm{a}$ will be offtaken for Turkish domestic consumption in Eskişehir and the remaining $10.9 \mathrm{bcm} / \mathrm{a}$ is for the European markets. The second stage of expansion up to $24 \mathrm{bcm} / \mathrm{a}$ is envisaged in 2023, by the time an additional $5 \mathrm{bcm} / \mathrm{a}$ of gas might come on-stream from the Absheron field and reach Turkish territory. By 2023, the total volume of gas to be transported to and via the Turkish territory reaches a maximum of $21-22 \mathrm{bcm} / \mathrm{a}$, although in the first year of ramp up from Absheron its volume may not exceed $2 \mathrm{bcm}$. In this case the overall volume passing through TANAP by the year of 2023 could be no more than $20 \mathrm{bcm}$. The contracted $6.6 \mathrm{bcm} / \mathrm{a}$ of natural gas from Shah Deniz Stage 1 for the Turkish domestic market will continue to be transported via the BOTAŞ gas transport system till 2021, the year of its expiry. 

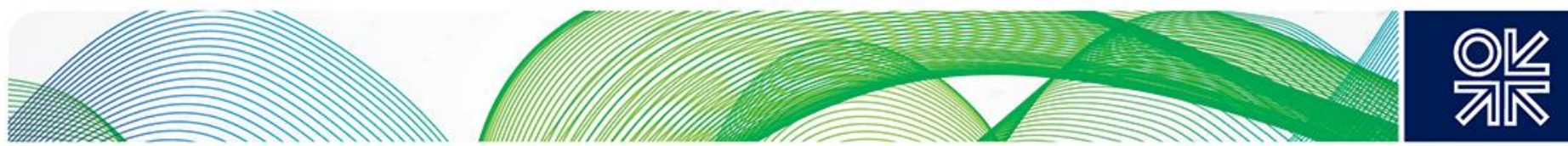

Figure 23: TANAP expansion stages

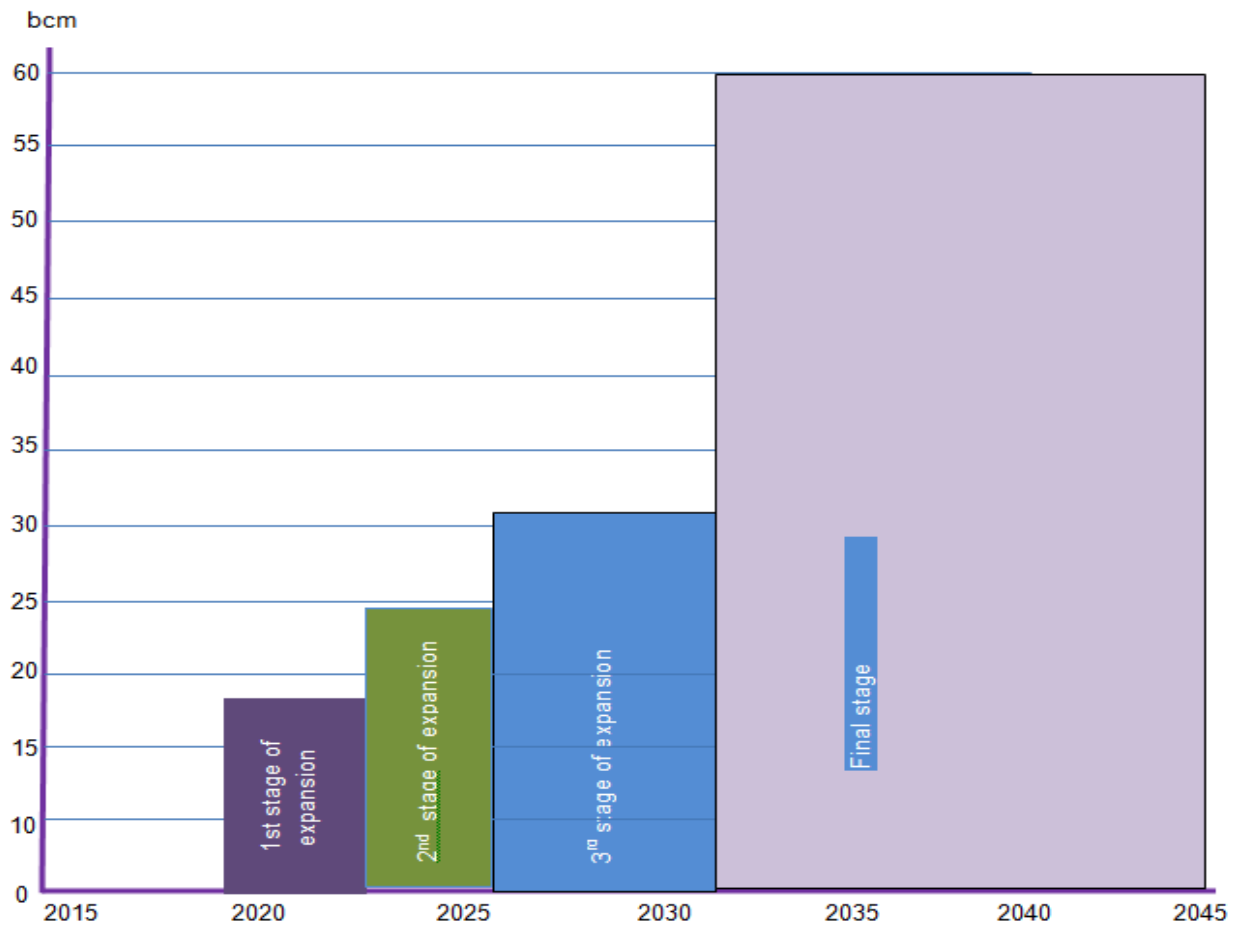

Source: Author (figures - TANAP)

The third stage of expansion of TANAP is planned to be in 2026, bringing total capacity up to 31 $\mathrm{bcm} / \mathrm{a}$. As mentioned in Section 5, the gas from Umid/Babek is likely to come on-stream by 20262027 , with a probable production of ca. 4-6 bcm/a. The non-associated gas from the ACG Deep structure is projected to be on-stream by $2027-2028$ with probable production volume of $4-5 \mathrm{bcm} / \mathrm{a}$. This additional volume will bring total volume to $29-33 \mathrm{bcm} / \mathrm{a}(21-22 \mathrm{bcm}+4-6 \mathrm{bcm}+4-5 \mathrm{bcm}=29-33$ $\mathrm{bcm})$. The TANAP expanded capacity of up to $31 \mathrm{bcm} / \mathrm{a}$ will almost cover all volumes of gas from Azerbaijan to come on-stream for export between 2023-2030.

The TANAP pipeline could be expanded to up to $60 \mathrm{bcm} / \mathrm{a}$ with looping, if needed in its final stage. This is envisaged for the gas coming from the Group 2 blocks and exploration prospects, with a possible annual volume of more than $20 \mathrm{bcm} / \mathrm{a}$. The timing of the ultimate expansion to $60 \mathrm{bcm} / \mathrm{a}$ is uncertain. This will depend on and be coincident with the timing of the gas coming e.g. from SD Phase 3, Nakhchivan in the early 2030s, Shafag-Asiman in the mid 2030s and the other blocks, if and when the capacity request arrives from the shippers (the companies developing the blocks). In addition, some additional capacity may be needed in the longer run for transiting/transporting gas from alternative sources such as Turkmenistan, Iraq, Iran and the Eastern Mediterranean to the European or Turkish markets.

\subsubsection{Trans-Adriatic pipeline (TAP)}

The Trans-Adriatic pipeline's initial capacity is $10 \mathrm{bcm} / \mathrm{a}$ to transport SD2 gas via Greece, Albania and Italy. It is planned that the pipeline will be expanded to up to $20 \mathrm{bcm} / \mathrm{a}$ by, for instance, increasing compressor station capacities and looping as soon as a firm capacity request arrives from a shipper. Generally, TAP is obliged to conduct a survey every 2 years to see if there is a potential shipper to book capacity. If a capacity request is made, a check of the shipper's minimum requirements is conducted (the criteria include minimum capacity reservation). If the capacity request is economically justified, then the capacity request will be executed. 

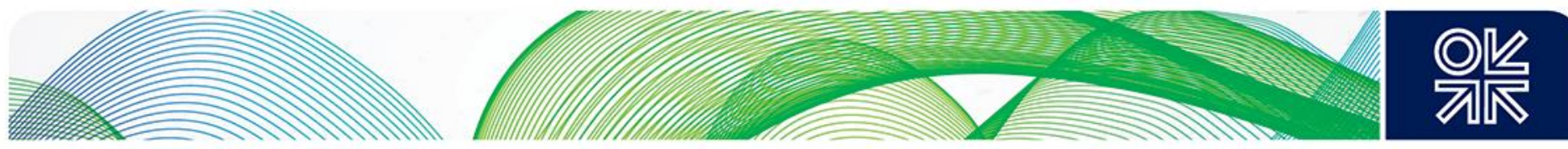

This means that it is possible for TAP to expand capacity to $20 \mathrm{bcm} / \mathrm{a}$ in 2022 when an additional 5 $\mathrm{bcm} / \mathrm{a}$ (total $15 \mathrm{bcm} / \mathrm{a}$ ) will be available to ship to the EU market. However, the companies supplying this $5 \mathrm{bcm} / \mathrm{a}$, if it is to be sold in Europe, would need to book capacity before gas sourced in any other country, including Russia (if Turkish Stream materializes) in order to secure access.

By 2028 up to 8-11 bcm/a of gas from Umid/Babek and ACG Deep may come on-stream, some of which also may target the EU market. (The other possible market for this gas could be the Turkish domestic market depending on price and supply/demand dynamics). This would make $24-27 \mathrm{bcm} / \mathrm{a}$ in total of gas volume for export to Europe by 2030 from Azerbaijan. For this, an additional $4-8 \mathrm{bcm} / \mathrm{a}$ capacity in TAP will be needed. If we add to this volumes of possible $20 \mathrm{bcm} / \mathrm{a}$ of gas from the Group 2 blocks, additional $24-28 \mathrm{bcm} / \mathrm{a}$ of capacity may be requested.

The further possible expansion of TAP will depend on the gas price in the market, and demand to make it financially viable. A second pipeline string would be possible if market conditions warranted it. As shown in Table 10, TAP also has multiple exit points for gas to be shipped to other south east European markets. An alternative option is therefore to ship gas via existing interconnectors through the Turkey-Greece/Bulgaria-Romania-Hungary route and/or to the Balkans via the Trans-Balkan pipeline. For that the capacity of this pipeline must be expanded as at the moment there is no spare capacity.

\section{Table 10: The total capacity allocated at each entry and exit point in TAP is presently as} follows:

\begin{tabular}{|l|l|c|}
\hline \multicolumn{1}{|c|}{ Location } & $\begin{array}{c}\text { Point } \\
\text { Type }\end{array}$ & $\begin{array}{c}\text { Total allocated } \\
\text { capacity, } \\
\text { approximately in } \\
\text { bcm/a }\end{array}$ \\
\hline Kipoi & Entry & 10.5 \\
\hline Komotini & Exit & 2.1 \\
\hline Nea Mesimvria & Exit & 0.4 \\
\hline $\begin{array}{l}\text { Snam Rete Gas tie- } \\
\text { in (Melendugno) }\end{array}$ & Entry* & 0.5 \\
\hline $\begin{array}{l}\text { Snam Rete Gas tie- } \\
\text { in (Melendugno) }\end{array}$ & Exit & 8.6 \\
\hline
\end{tabular}

${ }^{*}$ Commercial (virtual) reverse flow

Source: TAP ${ }^{100}$

\subsection{Suitable market for the future volumes}

Defining a suitable market and finding potential buyers for the gas is an important factor at the preFID stage. Usually companies investigate potential markets well before the commencement of the development stage; projecting supply/demand dynamics and pricing outlook for the long-term perspective. The findings of such assessments are needed to calculate the financial viability of the upstream project and possible rate of return.

As the gas from SD Stage 1 and 2 has already been contracted and sold to customers in Turkey and Europe, we consider in this section the potential market(s) for the natural gas coming from the Group

\footnotetext{
100 (Exit and Entry Points) Trans Adriatic Pipeline, Booking Phase Note, http://www.autorita.energia.it/allegati/docs/14/11214all.pdf;
} 

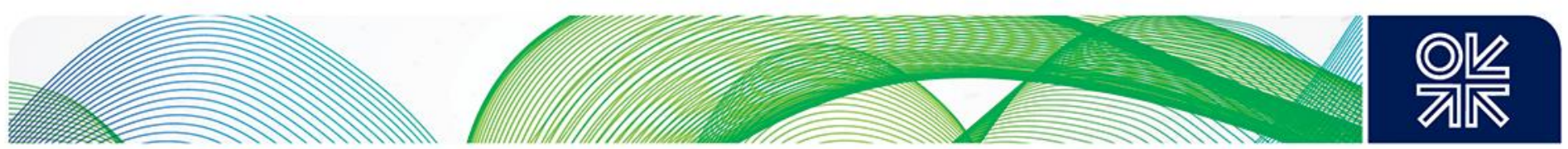

1 fields/structures (Absheron, Umid/Babek, ACG deep gas) in the 2020s and Group 2 field and blocks, exploration prospects (SD Phase 3, Nakhchivan, Shafag-Asiman, Zafar-Mashal, Garabagh, Inam) in the 2030s.

However, only two potential markets are realistic for the future volumes of gas from Azerbaijan - the Turkish and European markets. The Russian market (Northern Caucasus region) where gas from Azerbaijan could also be potentially exported due to existing demand, infrastructure, short distance and commerciality is not considered, as Gazprom may supply its own gas to that region. For Azerbaijan the European market is a priority market for mainly strategic and commercial reasons.

\subsubsection{The Turkish market}

The Turkish market is probably the most commercially suitable market for Azerbaijani gas due to the shorter transportation distances, high projected demand growth and currently supportive gas price levels. The Turkish natural gas market, including demand/supply projections and pricing, has been analyzed in an OIES paper published in February $2014^{101}$. That study considered BOTAŞ forecasts that Turkey's gas demand will almost double from $45 \mathrm{bcm} / \mathrm{y}$ in 2012 to $81 \mathrm{bcm} / \mathrm{a}$ by 2030 .

According to BOTAŞ, the main driver of this rapid growth will be gas-fired power generation. It is most likely to grow by up to $45 \mathrm{bcm} / \mathrm{a}$ by 2030 . And this is despite the government's target to reduce the share of gas in the overall power generation from the current $45 \%$ to $30 \%$ or even below, replacing it with domestic coal, lignite, renewable energy and nuclear. However, as demand for electricity is forecast to grow at $6-7 \% / a$, even with only $30 \%$ of the power market, gas demand growth will still be significant.

The second driver is the household sector, where demand is forecast to grow from 8-9 bcm/a in 2012 to $22.7 \mathrm{bcm} / \mathrm{a}$ in 2030. The industrial sector is the third factor contributing to overall natural gas demand growth; it is forecast to rise from $12.8 \mathrm{bcm} / \mathrm{a}$ in 2019 to $14.2 \mathrm{bcm} / \mathrm{a}$ in 2030. However, the study claims that, even in a high scenario, demand in Turkey is most likely to be at the level of around $67-70 \mathrm{bcm} / \mathrm{a}$ by 2030 , and that the BOTAŞ projection of $81 \mathrm{bcm} / \mathrm{a}$ is optimistic ${ }^{102}$. Even in a low case scenario, Turkey will need to import an additional $22-25 \mathrm{bcm} / \mathrm{a}$ of gas by 2030 .

Given the likely trend of Turkish natural gas demand growth the study also demonstrates that there may be periodic supply shortages:

a) After 2016 due to rising demand, before the start-up of deliveries from Shah Deniz II in 2018;

b) After 2021-2022 when a possible supply squeeze could occur, arising from the expiry of the Shah Deniz 1 (6.6 bcm/a) and the Gazprom Western Line contracts (4 bcm/a) (Figure 24).

c) The extension of both contracts will depend among other reasons, on the liberalization process of the market and desire of the suppliers to conclude contracts with the companies other than BOTAŞ.

\footnotetext{
${ }^{101}$ Rzayeva G. (2014)

${ }^{102}$ Rzayeva G. (2014)
} 

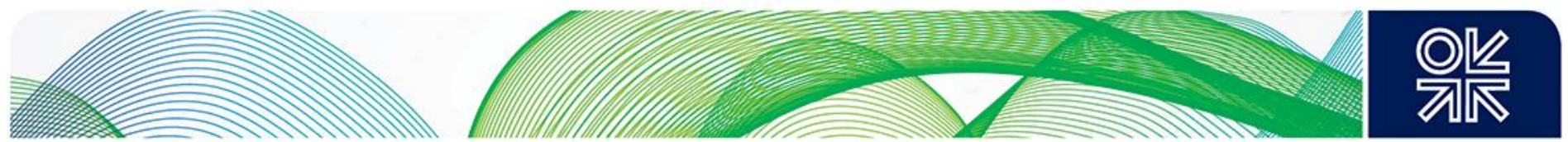

Figure 24: Natural gas supply by country to 2023 and demand

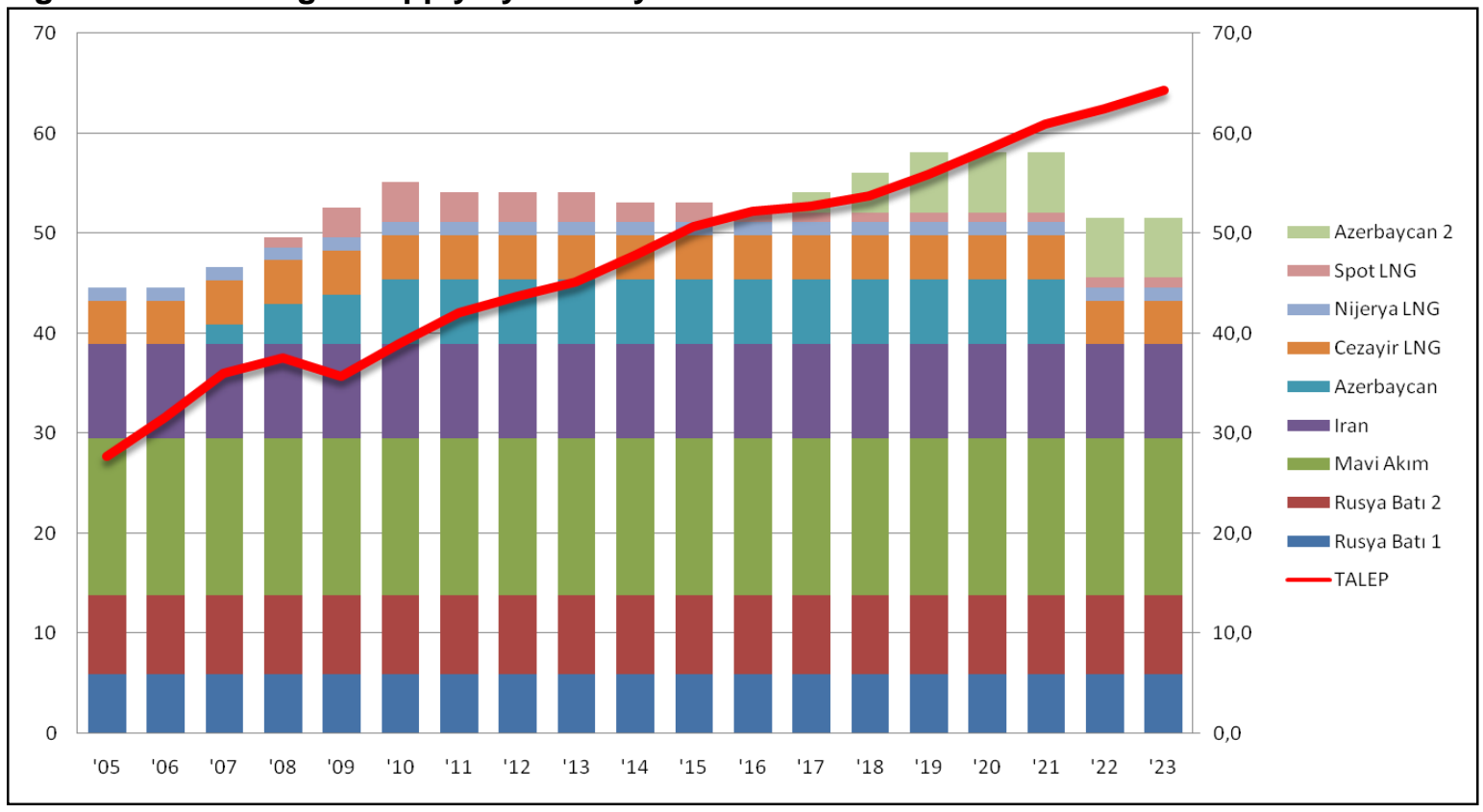

Source: BOTAŞ forecast in Rzayeva (2014) (p. 27)

According to the "Cooperation MoU between Gazprom and BOTAS" signed by Turkey and Russia in December 2014, Turkey will import an additional $3 \mathrm{bcm} /$ a from Russia from 2016 at a $6 \%$ discounted price to cover the possible supply gap. The two sides also agreed to import $14 \mathrm{bcm} / \mathrm{a}$ of gas for the Turkish market by a different route across the Black Sea to bypass Ukraine. For the same reason some $50 \mathrm{bcm} / \mathrm{a}$ of gas is envisaged to transport via the same route to the Turkish-Greek border for the EU market, according to the MOU ${ }^{103}$.

However, it needs to be clarified that these will apparently not be additional volumes, but the same 50 bcm of gas that Gazprom has contracted with its European customers at other defined delivery points, not at the Turkish-Greek border. An MOU has been signed by Gazprom and BOTAS on this pipeline, and Gazprom has stated that it hopes that an intergovernmental agreement will be in place in the second quarter of 2015. If and when it materializes, Turkey may benefit from the project by

a) solving the possible supply squeeze problem starting from 2016;

b) averting potential risks of gas interruptions possibly deriving from recent events in Ukraine by removing the transit country (Ukraine);

c) finally realizing its long-term goal to become a physical hub of the wider region by creating a connection point on the Turkish-Greek border (on the Turkish side, not to repeat scenario with South Stream) for delivering $50 \mathrm{bcm} / \mathrm{a}$ to establish a physical gas hub. This hub would be used as a reference point in Russian gas price formulas as soon as Turkey becomes a hub;

BOTAŞ proposed a $6 \%$ reduction in the Russian gas price $(\$ 385-390 / 1000 \mathrm{~cm})$ valid from January 2015. Furthermore, Gazprom has agreed to a $10.25 \%$ import gas price reduction for BOTAŞ (no price reduction has been made for private importers in Turkey), which will be enforced from March 1 

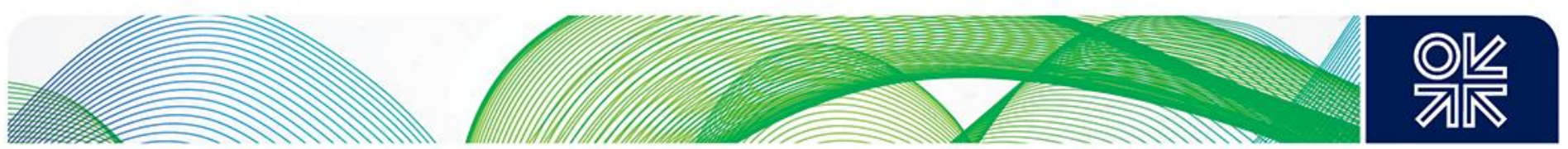

$2015^{104}$. It is important to note however that the fall in oil prices from late 2014 will materially reduce such pricing estimates.

This deal is unlikely to cause any serious damage to gas export plans in Azerbaijan for a number of reasons. It will not have any impact on SD Phase 1 and Phase 2 gas sales to both Turkey and Europe, simply because the volumes have been contracted already by the buyers. Because it is the same volume of Russian gas, merely delivered via a different route, it is unlikely to reduce the demand for gas sourced from Azerbaijan. Of course, Turkey can import additional volumes from Russia in the future, to cover the gap that may occur from 2021-2022. For that, Turkey has 2 options: either gas from the next wave of gas fields in Azerbaijan or increased import volumes from Russia. Any potential volumes either from Turkmenistan and KRG are highly unlikely in the mid-term perspective. The main driver for the decision of the Turkish government will be the price. Turkey currently pays the lowest price for imported pipeline gas from Azerbaijan. Meanwhile, Turkey will strengthen its negotiating position with other suppliers, including Azerbaijan, given the increased supply options. Turkey will obviously make every effort to avoid negotiating to purchase such imports from a disadvantaged position.

\subsubsection{The European market}

The European market is a priority market for Azerbaijan due to a number of reasons, primarily geopolitical and strategic ones. For Azerbaijan, it is important not to limit itself to and depend on one single market (Turkey), thus increasing risks of demand security and weakening its negotiation position.

However, the EU gas market growth outlook to 2020 does not generally seem to be optimistic. The perspective of market participants has been influenced by significant events and trends since early 2014, including the potential consequences of the political and military crisis in Ukraine, the growing likelihood of significant U.S. LNG exports from 2016, the impact of new Australian LNG supplies from 2015 and the apparent slow-down of LNG demand in Asia. Natural gas is being out-competed by lower priced coal in the European power generation sector, despite the obvious higher $\mathrm{CO}_{2}$ emission consequences, highlighting the failure of the European Emissions Trading System.

These and other factors, not least the sluggish economic growth in the Eurozone post the financial crisis of 2008, are affecting the overall gas demand growth in the market. According to the IEA, demand will be at its best stagnant in Europe at least till 2020 and the 2010 level will only be reached again around the 2030s. According to an OIES research paper on the outlook for natural gas demand ${ }^{105}$ total demand for the 35 countries will recover from present levels to $564 \mathrm{bcm}$ in 2020 (from $594 \mathrm{bcm}$ in 2010). ${ }^{106}$

Despite the factors that negatively affect demand growth in the mid- and long-run, gas import from alternative sources will be a priority for European countries. According to an OIES study on reducing European dependence on Russian gas ${ }^{107}$, up to the mid-2020s European companies are contractually obliged to import at least $115 \mathrm{bcm} / \mathrm{a}$ of Russian gas (approximately $75 \%$ of the 2013 import level), a figure which reduces to around $65 \mathrm{bcm} / \mathrm{a}$ by 2030 .

It is possible that countries with concerns regarding their high level dependency on Russian gas imports may seek early contract termination (assuming they have been able to develop the

\footnotetext{
104 "Gazprom reduces import price for Turkey's BOTAS, but uncertainty lingers for private gas sector", 27 February 2015, ICIS, http://www.icis.com/resources/news/2015/02/27/9864841/gazprom-reduces-import-price-for-turkey-s-botas-but-uncertaintylingers-for-private-gas-sector/

${ }^{105}$ Honore A. (2014b)

${ }^{106}$ World Energy Outlook 2014

107 Stern J. et al (2014), OIES
} 

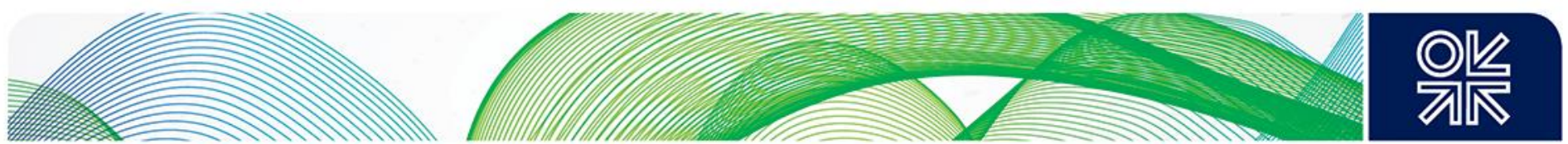

infrastructure for alternative supplies and are willing to pay whatever contractual penalties are due) or that they may reduce import volume upon the contract expiry.

The main driver for Europe's higher future import requirements however is the inevitable decline of indigenous production. By 2030 conventional gas production in Europe will decline to around 110 $\mathrm{bcm} / \mathrm{a}$ (Figure 25) ${ }^{108}$. The situation is made worse by the likely deterioration in export volumes from North African countries (including Algeria and Libya), the biggest gas suppliers from the region to the Southern European countries. This is due to the challenge in attracting sufficient new upstream investments, and increased domestic demand. Pipeline gas exports from Algeria for instance are projected to decline from $28 \mathrm{bcm} / \mathrm{a}$ in 2015 to $20 \mathrm{bcm} / \mathrm{a}$ in 2020 and $22 \mathrm{bcm} / \mathrm{a}$ in 2030. ${ }^{109}$

Figure 25: European gas production and imports

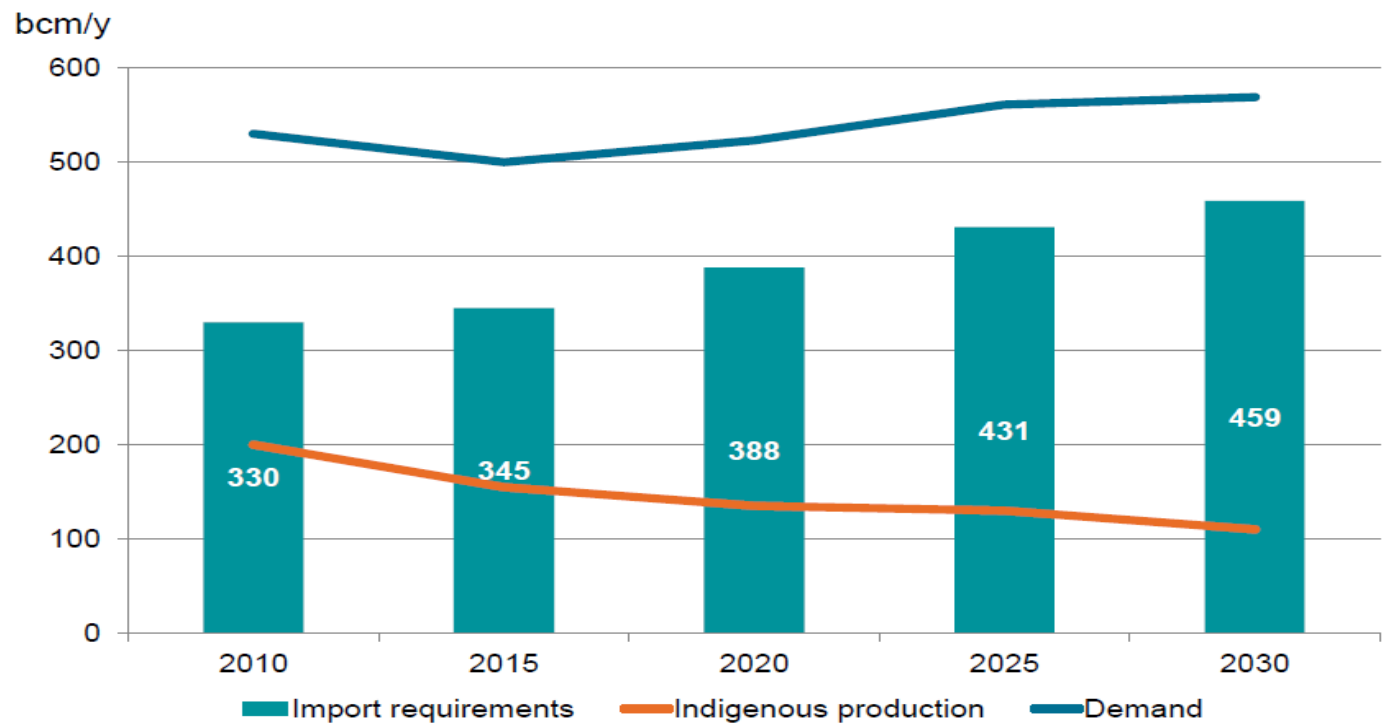

Source: Fluxys

In terms of additional European pipeline gas imports, Azerbaijan is the only firm non-Russian option for supplies of more than $10 \mathrm{bcm} / \mathrm{a}$ from around 2020, given that it has secured all necessary binding agreements. Apart from pipeline gas imports, there is however significant potential for Europe to increase its LNG imports from diverse sources. There is substantial spare capacity at re-gasification terminals in Europe (up to $200 \mathrm{bcm} / \mathrm{a}$ ) of which only $42 \mathrm{bcm} / \mathrm{a}$ was utilized in $2013^{110}$.

However, there is much uncertainty over the scale of future LNG supply available to Europe ${ }^{111}$. By 2018 Australian LNG projects currently completing construction will add some $85 \mathrm{bcm} / \mathrm{a}$ to global supply and $70 \mathrm{bcm} / \mathrm{a}$ of US export projects are also under construction. In the low oil-indexed and gas hub price environment of early 2015, it may be that projects not yet having achieved FID in East Africa, Canada, further projects in Australia and projects in Russia other than Yamal Train 1 - may be delayed. On the demand side, uncertainties in future Asian LNG demand may result in the diversion of significant volumes of LNG to Europe which will put further pressure on gas prices.

\footnotetext{
${ }^{108}$ Stern et al (2014), OIES

${ }^{109}$ El-Katiri (2014), OIES

${ }^{110}$ BP Statistical Review of World Energy, 2014 (Belgium, France, Italy, Spain, UK)

${ }^{111}$ For details see, Stern et al (2014, p. 31)
} 

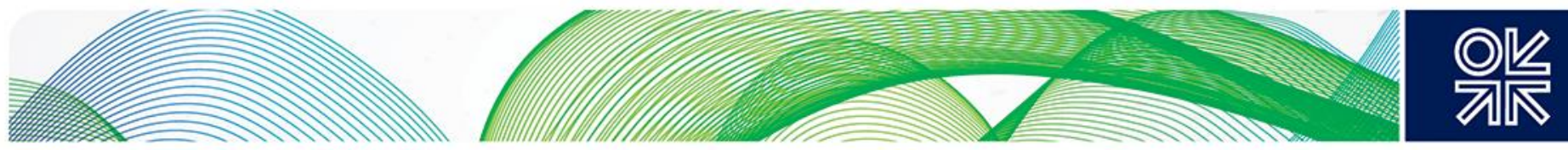

Figure 26: European gas supply-demand balance, bcm

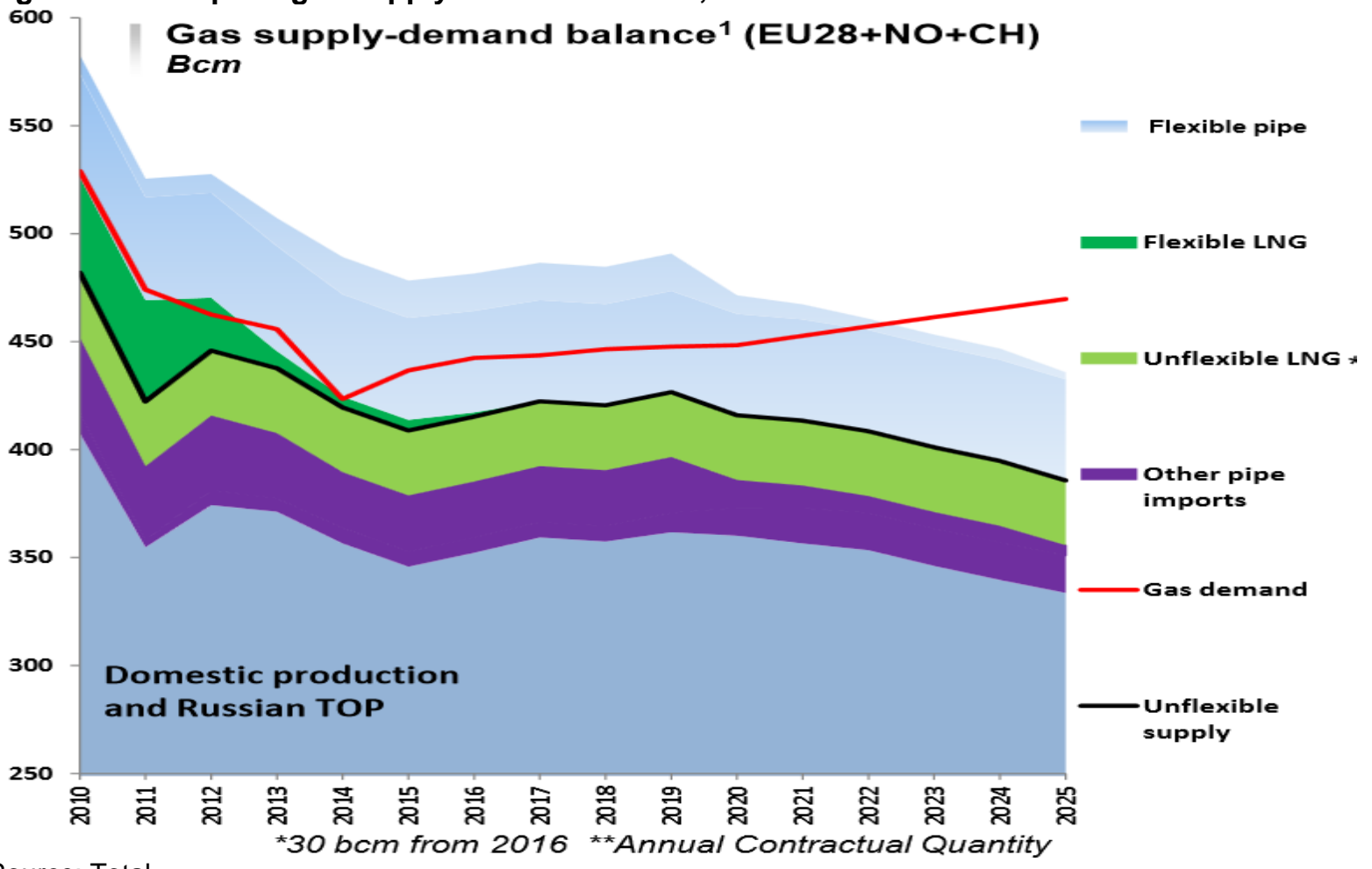

Source: Total

In the most optimistic scenario for Europe of significantly increased LNG imports, additional pipeline gas imports will still be required. Given the likely future Turkish gas demand growth and its need to import additional volumes of gas, and the current high netback returns from sales to this particular market, we may assume that at least half of the $15 \mathrm{bcm} / \mathrm{a}$ of Azerbaijan's un-contracted "free" gas available in the 2020s can be absorbed by Turkey. The remaining $7+\mathrm{bcm} / \mathrm{a}$ may be absorbed in Southeast European countries (Bulgaria, Romania, Macedonia, Serbia) and Central European countries (Czech Republic, Slovakia, Poland) and the Balkans with alternative supplies diverted to more northerly markets where domestic production decline will absorb such volumes. The reliance of South East European countries on Russian gas as the main (and in some case only supplier) may change when their long-term contracts with Gazprom begin to expire in the 2020s. A Gazprom supply contract to Bulgaria expires in 2022, to Serbia (Yugorasgas) in 2021, to Slovakia (SPP - Distribucia) in 2028, to Slovenia (Geoplin) in $2017^{112}$ etc. Azerbaijan-sourced gas to these countries can be transported via existing or planned interconnectors, which will make the cost of transportation lower and provide supply diversity. The Balkans is the only region in Europe, where demand is expected to grow rapidly by 2030 according to the Croatian Energy Institute. The total gas consumption in the region in 2012 was $5.5 \mathrm{bcm} / \mathrm{a}$, and is expected to rise to $17.1 \mathrm{bcm}$ in $2030^{113}$.

The Greek market is already committed to purchase SD2 gas and is limited in scale. The Italian market despite uncertainties over future demand growth may be viewed as an advantageous market for additional future Azerbaijani volumes, effectively displacing flows into Italy from Northern Europe. In this scenario however it is highly unlikely that the Italian hub price would be at a premium to North West European prices.

\footnotetext{
${ }^{112}$ Cedigaz report available for subscribers

${ }^{113}$ Croatian Energy Institute Hrvoje Požar's report on the Balkans gas demand. Forecasts are results of the institute's analysis and modelling as a part of market analysis for several regional projects like the IAP pipeline, LNG terminal on island Krk etc.
} 

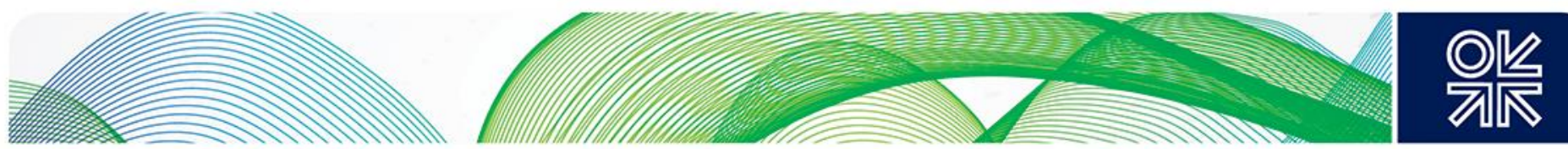

\subsection{Summary}

The companies developing fields and prospective structures in Azerbaijan require a sound understanding of the natural gas market development in Europe and Turkey - the key potential markets for future volumes, to be able to define the most suitable form of marketing. The gas producing companies have to define whether it will be more commercially viable for them to sell the gas to SOCAR at the production point, and not to take all the possible financial technical risks in transporting the gas to the market. As well, SOCAR has to calculate whether it is capable of undertaking all the responsibilities and risks of doing so.

The infrastructure to be built and expanded for such volumes seems to be sufficient to transport some additional $15 \mathrm{bcm}$ in the 2020s and $20 \mathrm{bcm}$ in the 2030s. This will be possible to achieve via further expansion of SCP for the volumes from Umid/Babek (4-6 bcm/a) and ACG deep layer gas (4-5 $\mathrm{bcm} / \mathrm{a}$ ), and subsequently via future further expansion of SCP for an additional $20 \mathrm{bcm} / \mathrm{a}$ for the gas from Group 2 prospective structures. The gas from the Absheron (2022) field can be potentially transported via SCP, as currently the total $8 \mathrm{bcm} / \mathrm{a}$ of capacity is not fully utilized due to BOTAS offtake constraints (although this may be viewed as too high a risk for Absheron field participants).

It is planned that the SCPx and SCPfx will be connected to and integrated into one system with TANAP, the scalable pipeline to transport all volumes of gas available from Azerbaijan to Turkish and European markets. TANAP stage by stage expansion will be capable to accommodate an additional $15 \mathrm{bcm} / \mathrm{a}$ in the $2020 \mathrm{~s}$ and $20 \mathrm{bcm} / \mathrm{a}$ in the 2030s with possible expansion up to $60 \mathrm{bcm} / \mathrm{a}$ if needed.

There may be a ready market niche for new alternative gas supply sources in South East Europe, Central Europe and the Balkans as these regions are keen to reduce dependency on Russia as their primary (or sole) source (and in the 2020s some of their LTSCs with Gazprom are expiring). Azerbaijani gas could potentially substitute some of these volumes. 

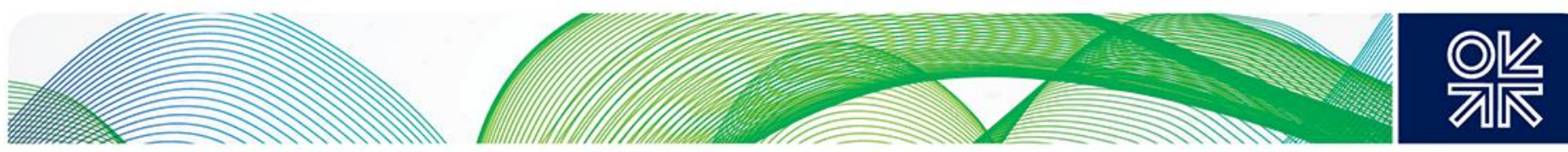

\section{Conclusions}

Despite a number of disappointing wells, the south Caspian Sea remains under-explored and considerable potential for the large hydrocarbon accumulations exists, especially in the Azerbaijani sector. Further exploration drilling on the prospective structures may reveal encouraging results, proving-up estimated gas resource potential.

In this paper we have provided the historical context for hydrocarbon production in Azerbaijan, described the significant gas production developments post 1990 and attempted to analyze the potential un-contracted gas volumes that may be available for export in the 2020s and 2030s from the next wave of gas production in Azerbaijan. We classified those fields and resources in two Groups (Group 1 - "probable production" and Group 2 "technical", the production from which is more challenging). All the gas available for export from SD Phase 1 and 2 is contracted. The tail off period of SD2 starts in the late 2030s, and the contracts with the EU buyers expire in 2045 (the SD PSA was expanded till 2048). We may therefore assume that the SD partners have a firm intention to explore, develop and produce gas from the SD Phase 3 to maintain gas deliveries to customers in accordance with the GSAs. The third phase of the project is envisaged to be developed in the early 2030s and potentially the production from this phase may add an additional $10 \mathrm{bcm} / \mathrm{a}$ at the plateau level to the export portfolio given the size of the field $(1.2 \mathrm{tcm})$.

Apart from the currently producing SD field, SOCAR has its own gas production from oil (associated gas) and gas fields that are mature and past their peak production. The company has launched a strategy of investing to increase recovery and production from these fields. Despite this, given the maturity of its existing fields, SOCAR will be looking more to production from within the joint ventures such as ACG, Shah Deniz, Umid; also from the resources offshore the Caspian Sea.

We included in Group 1 three fields and perspective structures: Absheron, ACG NAG Umid/Babek, given their current development status and intentions of the companies developing them. However they may also contain a component of technical reserves (i.e. the reserves that are currently considered uneconomic to exploit), which may be due to a combination of factors such as development costs, gas and oil prices, constraints in availability of equipment and facilities such as drilling rigs, vessels, etc. or gas reserves for which no commercial outlet is yet on the horizon. Nevertheless, based on estimates available at this time and assuming all key challenges are resolved, we can conclude that gas production in Azerbaijan during the period 2021-2030 from the Group 1 commercial fields/discoveries may be more than $15 \mathrm{bcm} / \mathrm{a}$ of gas available for export.

At the moment, the biggest challenge for exploration, appraisal and development drilling is the availability of drilling rigs. Currently it is uncertain what decision SOCAR will take on the rig now under construction, once it is available in 2017, i.e. whether to use it for SD Phase 3, Absheron, ACG nonassociated gas, drill more wells in ACG to increase production of oil or Umid/Babek, once the tender is finalized. The first contender for production, the Absheron field, is expected to be granted a rig by 2018 at the latest to start production late 2021. If the new rig is not available for Absheron, Total will probably proceed directly to development work, constructing a production platform incorporating its own drilling rig.

Within the Group 2 resources we classified blocks that have not yet been the subject of exploration drilling, or where this has been done, the results were inconclusive. Those are SD3 Nakhchivan, Shafag-Asiman, Zafar-Mashal, Garabagh, Alov-Araz-Sharg, and Inam. This is probably not the case for the Shah Deniz Phase 3 as the consortium has secured buyers for 25 years from 2020. We assume that the most probable gas that can come on stream within the Phase 2 production in Azerbaijan and among the Group 2 fields is SD3.

Nevertheless, for identifying the total "surplus" of uncommitted natural gas possibly available from the Group 2 prospects, we estimated the probable annual production (defined based on the size and 

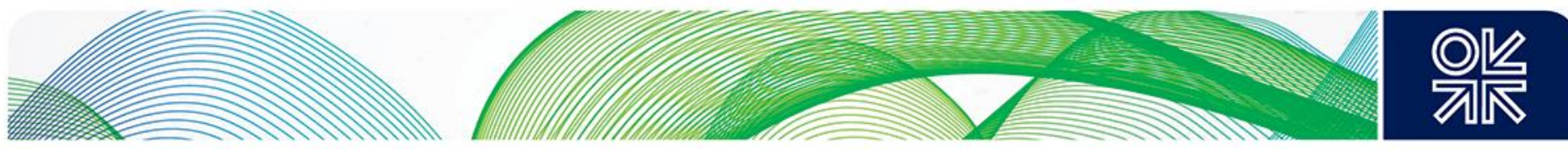

lifetime of the prospective structures). We assume that the overall natural gas volumes to be available for export in the 2030s from the Group 2 exploration prospects could reach more than $20 \mathrm{bcm} / \mathrm{a}$ (Figure 21), including SD3 gas and excluding some $8 \mathrm{bcm} / \mathrm{a}$ of gas from Araz-Alov-Sharg. Due to many uncertainties existing with the exploration plans of this block of SOCAR, this figure is indicative only.

The current annual natural gas consumption in Azerbaijan is up to $10 \mathrm{bcm} / \mathrm{a}$. SOCAR supplies gas for the domestic market from its own portfolio. The country's gas demand is unlikely to grow significantly in the next years. Domestic demand would be expected to grow at the expense of planned development of non-oil sector industry in the mid- and long run. However, domestic investment in the non-oil projects will depend on many macro-economic developments and primarily the oil price. Having said that we assume that by the end of the 2030s the demand may not grow to more than 20 $\mathrm{bcm} / \mathrm{a}$ in a high case scenario. This gas could be covered from the SOCAR share in SD $(16.7 \%)$, associated gas from the oil fields as well as from the SOCAR share in the fields of Group 1 (Absheron, Umid/Babek, ACG NAG) in accordace with the PSAs.

The development of the prospective structures is very much dependent on the availability of buyers and market development. No less important is the availability of capacity in the infrastructure to transport future potential natural gas to market.

The infrastructure to be built and expanded for those volumes seems to be sufficient to transport some additional $15 \mathrm{bcm} / \mathrm{a}$ in the $2020 \mathrm{~s}$ and $20 \mathrm{bcm} / \mathrm{a}$ in the 2030s. This could be achieved via further expansion of SCP for the volumes from Umid/Babek (4-6 bcm/a) and ACG deep layer gas (4-5 $\mathrm{bcm} / \mathrm{a}$ ), but also probable so-called future further expansion of SCP for an additional $20 \mathrm{bcm} / \mathrm{a}$ for the gas from Group 2 prospective structures. The gas from the Absheron (2022) field can be potentially transported via the SCP pipeline, as currently the total $8 \mathrm{bcm} /$ a of capacity is not fully utilized because of the constraint on BOTAŞ offtakes. TANAP stage by stage expansion will be capable of accommodating an additional $15 \mathrm{bcm} / \mathrm{a}$ in the $2020 \mathrm{~s}$ and $20 \mathrm{bcm} / \mathrm{a}$ in the $2030 \mathrm{~s}$ with possible expansion up to $60 \mathrm{bcm} / \mathrm{a}$ if needed.

The Turkish market seems to be the most commercially viable for Azerbaijani gas due to the short distance, growing demand and suitable price. However depending on one single market does not meet the strategic need of the gas producing companies seeking to diversify market risk. The European market is the second most suitable market. We assume that at least half of the gas available for export in the 2020s (7 bcm/a) could be delivered to Turkey and the rest transported to the EU market. There can be a ready market for Azerbaijani gas in the countries of the SEE, Central Europe and the Balkans as these are keen to diversify away from Gazprom supplies in the 2020s when some of their legacy LTSCs expire. 

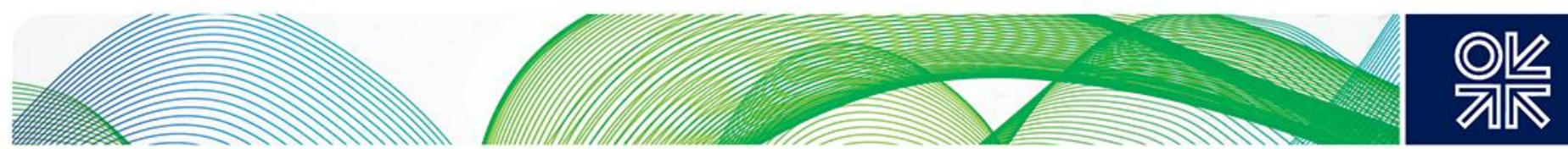

\section{Glossary}

ACG: Azeri-Chirag-Guneshli field

ACG NAG: Azeri-Chirag-Guneshli non-associated gas

AIOC: Azerbaijan International Operating Company

AGSC: Azerbaijan Gas Supply Company

ACQ: Annual Contract Quantity

ARC: Annual Reserve Capacity

Bcm: One billion cubic metres

$\mathrm{Bcm} / \mathrm{a}:$ One billion cubic metres per annum

BOTAŞ: Petroleum Pipeline Corporation (Boru Hatları Ille Petrol Taşıma A.Ş)

BP: British Petroleum

CIS: Commonwealth of Independent States

CIPCO: Caspian International Petroleum Company

CDC: Caspian Drilling Company

EUC: European Commission

EDPSA: Exploration \& Development Production Sharing Agreement

EUGSAs: European Gas Sales Agreements

EAOC: Exxon Azerbaijan Operating Company

FEED: Front End Engineering Design

FID: Final Investment Decision

FSU: Former Soviet Union

GTA: Gas Transport Agreement

GOGC: Georgian Oil and Gas Corporation

GSA: Gas Sale Agreement

GNT: Gas Negotiation Team

HGA: Host Governmental Agreement

Hub: A point at which gas is traded, either a physical or virtual location

IAP: Ionian Adriatic Pipeline

IEA: International Energy Agency

IGA: Intergovernmental Agreement

IGAT: Iran Gas Trunkline

IGB: Interconnector Greece-Bulgaria

IJV: Incorporated Joint Venture

IOCs: International Oil Companies

JOA: Joint Operational Agreement

JV: Joint Venture 

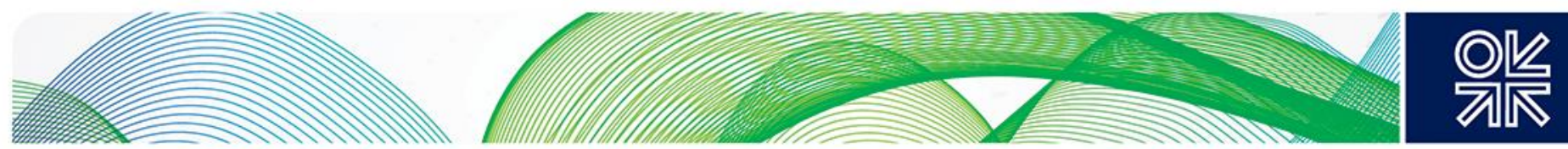

KNOC: Korean National Oil Company

KWh: kilowatt/hour

LNG: Liquefied Natural Gas

LTSC: Long-term supply contract

MM: Millimetre

MCM: Million Cubic Metres

MOU: Memorandum of Understanding

MMBtu: Million British thermal units

NAG: Non-associated gas

NAR: Nakhchivan Autonomous Republic

OGPC: Oil \& Gas Processing Company

PSA: Production Sharing Agreement

PSC: Production Sharing Contract

PSV: Punto di Scambio Virtuale, the Italian gas trading hub

RSFSR: Russian Soviet Federal Socialist Republic of Azerbaijan

SCP: South Caucasus Pipeline

SCPC: South Caucasus Pipeline Company Limited

SCPx: South Caucasus Pipeline expansion

SCPfx: South Caucasus Pipeline future expansion

SCPffx: South Caucasus Pipeline further future expansion

SD1, SD2, SD3: Shah Deniz Phase 1, Phase 2 and Phase 3

SEE: South East Europe

SGC: The Southern Gas Corridor

SOA: SOCAR Oil Affiliate

SOCAR: State Oil Company of the Republic of Azerbaijan

SSCRA: State Statistical Committee of the Republic of Azerbaijan

TANAP: Trans-Anatolian Natural Gas Pipeline

TAP: Trans-Adriatic Pipeline

TAG: Trans-Austria Pipeline

Tcm: Trillion cubic metres

TENP: Trans Europa Naturgas Pipeline

TPA: Third Party Access

TPAO: Turkish Petroleum Corporation

TSO: Transmission System Operator

UJV: Unicorporated Joint Venture

USSR: United Soviet Socialist Republic

VAT: Value Added Tax 


\section{Bibliography}

Azerbaijan sources:

Azerbaijan National Encyclopedia, Baku 2007

Oil Strategy of Heydar Aliyev: For independence and well-being of Azerbaijan, Part 2, Baku, 2001

Gorny Journal, 1872, \#3, p.20

Energy Institute Hrvoje Požar Reports „Demand/Supply Dynamics in the Balkans“

“Iki Sahil” journal, R.Abdullayev'v article. \# 25 (6200), 20.09.2014, available in Azerbaijani

Company and Official websites:

\section{BOTAS}

BOTAS Natural gas sale and purchase agreements, http://www.botas.gov.tr/index.asp

\section{Caspian Drilling Company}

website http://www.caspiandrilling.com/browse.php?sec id=13

\section{BP}

BP-Azerbaijan company's report for six months, 2014,

http://www.bp.com/en az/caspian/press/businessupdates/2014-first-half-results.html

\section{Gas Natural Fenosa}

"Gas Natural Fenosa signs a long-term deal to buy natural gas from Azerbaijan with the Shah Deniz consortium",

http://www.gasnaturalfenosa.com/en/home/press+room/news/1285338473668/1297156193407/gas+ natural+fenosa+signs+a+long-

term+deal+to+buy+natural+gas+from+azerbaijan+with+the+shah+deniz+consortium.html

\section{Gazprom}

New gas pipeline towards Turkey",

http://www.gazprom.com/press/news/2014/december/article208505/, 2 December 2014

Keppel

Keppel O\&M to build semisubmersible worth about US $\$ 800$ million for Azerbaijan, http://www.kepcorp.com/en/news item.aspx?sid=3963

\section{Shah Deniz}

Shah Deniz Project timeline, BP's official webpage,

http://www.bp.com/en az/caspian/operationsprojects/Shahdeniz/projecthistory.html

Shah Deniz Stage 1, BP's official website:

http://www.bp.com/en az/caspian/operationsprojects/Shahdeniz/SDstage1.html 

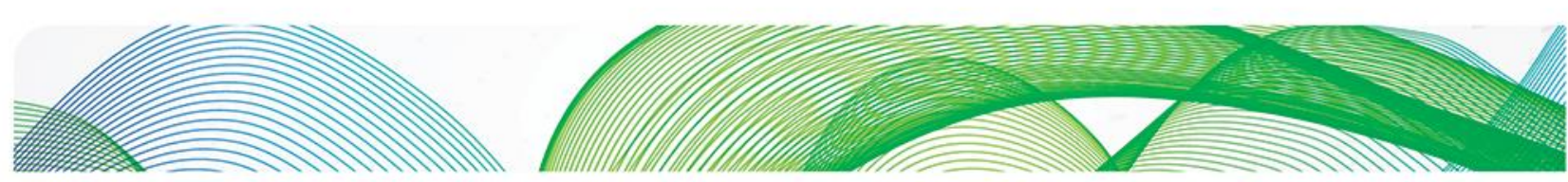

Shah Deniz Final Investment Decision Paves Way for Southern Caspian Drilling Company's website, BP Press Release, 17 December 2013, , http://www.bp.com/en/global/corporate/press/pressreleases/shah-deniz-final-investment-decision-paves-way.html

\section{SNAM}

Gas Regional Investment Plan (GRIP) for "Southern Corridor" region for 2012-202, http://www.snamretegas.it/export/sites/snamretegas/repository/attivita/scenario/GRIP SNC.pdf SOCAR

SOCAR representative presentation made at the Malta Energy Conference on 10-11 July 2014 SOCAR's official web page: http://www.socar.az/socar/az/home/

SOCAR Annual Development Report, 2013, http://www.socar.az/socar/assets/documents/en/socarannual-reports/sus.dev.rep-2013.pdf

State Oil Company of the Azerbaijan Republic, International Financial Reporting Standards, Consolidated Financial Statements, 31 December 2013, http://www.socar.az/socar/assets/documents/en/socar-financial-reports/2013.pdf

\section{South Caucasus pipeline}

website http://www.bp.com/en az/caspian/operationsprojects/pipelines/SCP.html

\section{STATOIL}

"Statoil's farm down in Shah Deniz and South Caucasus Pipeline completed", http://www.statoil.com/en/NewsAndMedia/News/2014/Pages/06May ShahDeniz.aspx TAP

Official web page, http://www.tap-ag.com/

Trans Adriatic Pipeline Booking Phase Notice, http://www.autorita.energia.it/allegati/docs/14/11214all.pdf

\section{Turkish Market Regulatory Authority}

Annual Turkish Natural Gas Market Sector Report for the years of 2010, 2011, 2012 and 2013, EMRA http://www.epdk.org.tr/documents/dogalgaz/rapor yayin/Dpd Rapor Yayin Sektor Raporu 2013.pdf

\section{OIES papers:}

Bowden (2009); Julian Bowden, "Azerbaijan: from gas importer to gas exporter", in Pirani et al (2009) http://www.oxfordenergy.org/shop/russian-and-cis-gas-markets-and-their-impact-on-europe El-Katiri (2014) El-Katiri L., A Roadmap for Renewable Energy in the Middle East and North Africa', OIES, http://www.oxfordenergy.org/wpcms/wp-content/uploads/2014/01/MEP-6.pdf Honore (2014a) Honore A., The Italian Gas Market: Challenges and Opportunities, OIES, http://www.oxfordenergy.org/wpcms/wp-content/uploads/2013/06/NG-76.pdf Honore (2014b) Honore A., The Outlook for Natural Gas Demand in Europe, (2014), http://www.oxfordenergy.org/wpcms/wp-content/uploads/2014/06/NG-87.pdf Jalilvand (2013) Jalilvand, David R., Iran's gas exports: Can past failure become future success? OIES, June 2013, http://www.oxfordenergy.org/wpcms/wp-content/uploads/2013/06/NG-78.pdf 

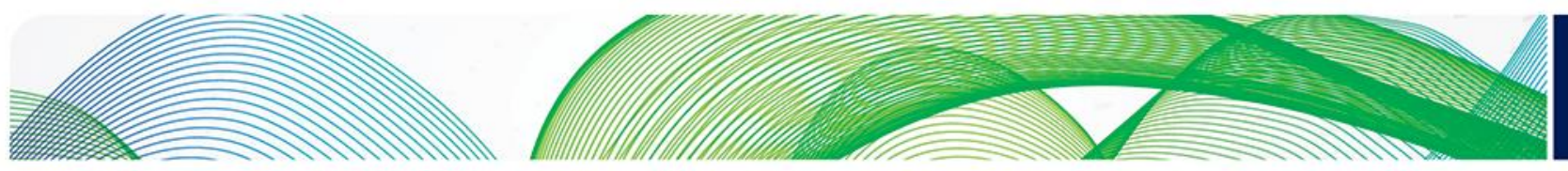

Pirani (2012) Pirani S., Central Asia and Caspian Gas Production and the Constraints on Export,

OIES, http://www.oxfordenergy.org/wpcms/wp-content/uploads/2012/12/NG 69.pdf

Pirani et al (2009); Russian and CIS gas markets and their impact on Europe,

http://www.oxfordenergy.org/shop/russian-and-cis-gas-markets-and-their-impact-on-europe/

Rzayeva (2014), Natural Gas in the Turkish Domestic Energy Market: Policies and Challenges, OIES,

February 2014,http://www.oxfordenergy.org/2014/02/natural-gas-in-the-turkish-domestic-energy-

market-policies-and-challenges/

Stern et al (2014) Stern J. et al, Reducing European dependence on Russian gas: Destiquishing natural gas from geopolitics, http://www.oxfordenergy.org/wpcms/wp-content/uploads/2014/10/NG-

92.pdf

Stern and Rogers (2014) Stern J., and Rogers H., The Dynamics of a Liberalised European Gas

Market, OIES, http://www.oxfordenergy.org/wpcms/wp-content/uploads/2014/12/NG-94.pdf

Public domain:

AL Kook interview: Arrangements with BP ensured Azerbaijan and SOCAR control over all 4 pipelines of Southern Gas Corridor to Europe, ABC, http://abc.az/eng/interview/162.html

Azerbaijan Country Overview, Wood Mackenzie geological report, Wood Mackenzie, 2013

Azerbaijan i Siriya dostigli predvaritelnogo soglasheniya o cene na gas,

http://1news.az/economy/oil $n$ gas/20100630121957286.html

Azerbaijan to resume gas export to Russia soon, http://www.azernews.az/oil and gas/67664.html

Azerbaijan to increase gas supply through Iran, http://en.trend.az/capital/energy/2302125.html COMMISSION STAFF WORKING DOCUMENT. In depth study of European Energy Security, Accompanying the document Communication from the Commission to the Council and the European

Parliament: European energy security strategy; $\{\operatorname{COM}(2014) 330$ final $\}$; Brussels, 2.7.2014,

SWD(2014) 330 final/3

Enerdata - independent Research \& Consulting firm on the global oil, gas, coal, power, renewable and carbon markets: http://www.enerdata.net/enerdatauk/press-and-publication/energy-news-

001/shah-deniz-consortium-signs-10-bcmyear-gas-supply-agreements 22360.html

Expansion of SCP pipeline to transport Shah Deniz gas to end in 2018,

http://www.azernews.az/oil and gas/50786.html

Gas Regional Investment Plan for the "South-North" for 2012-2021

Gazprom reduces import price for Turkey's BOTAS, but uncertainty lingers for private gas sector, ICIS, 27 February 2015, http://www.icis.com/resources/news/2015/02/27/9864841/gazprom-reducesimport-price-for-turkey-s-botas-but-uncertainty-lingers-for-private-gas-sector/

Germany's E.ON to buy 40 bcm of Azerbaijani gas under 25 year-contract, Trend, http://en.trend.az/business/energy/2193375.html, 23 September 2013

Germany approves RWE Dea sale, http://www.offshoreenergytoday.com/germany-approves-rwe-dea$\underline{\text { sale/ }}$ 

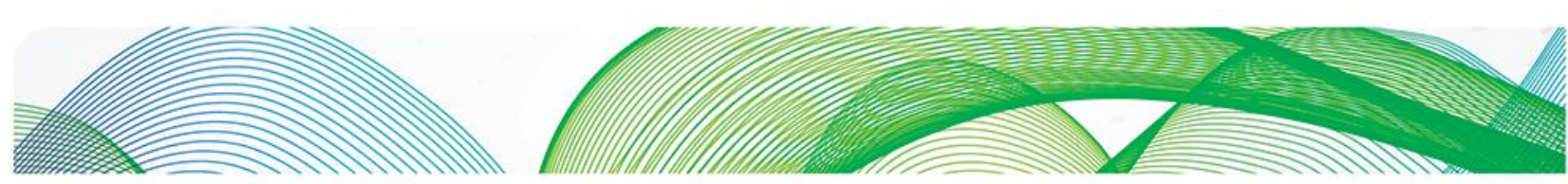

Greece may reach agreement with Turkey in natural gas dispute,

http://www.todayszaman.com/business greece-may-reach-agreement-with-turkey-in-natural-gasdispute 257519.html

Infrastruktura dla realizacii proyekta "Energiticheskiy most Azerbaydjan-Gruziya-Turciya" prakticheski gotova, http://www.oilcapital.ru/industry/252148.html

Italian gas deals with Azerbaijan to break systemic oil-link, Reuters,

http://www.reuters.com/article/2014/04/29/italy-gas-azerbaiian-idUSL6N0N942A20140429

Italy's National Energy Strategy, March 2013,

http://www.encharter.org/fileadmin/user upload/Energy policies and legislation/Italy 2013 National

Energy Strategy ENG.pdf

Jordan Seeks to Import Oil and Gas From Azerbaijan, http://www.bloomberg.com/news/2011-04-

13/jordan-seeks-to-import-oil-and-gas-from-azerbaijan-petra-says.html

Presentation of Clara Poletti, Head of the Department for Regulation AEEGSI,

http://www.ispionline.it/it/documents/Workshop06.02.14Presentazione.Poletti.pdf

Presentation of the first vice-president of SOCAR Khoshbakht Yusifzade at the 21st Caspian Oil \&

Gas Conference, http://www.caspianoil-

gas.com/presentations/documents/OKhoshbakhtYusifzadeh.pdf

Rusya doğalgaza yüzde 8 değil, yüzde 4 indirim yaptı (Russia made $4 \%$ of discount for natural gas import for Turkey, not 8\%), http://www.zaman.com.tr/ekonomi haber-inceleme-rusya-dogalgazayuzde-8-degil-yuzde-4-indirim-yapti 2071769.html

RWE: Developing perspective offshore Nakhchivan field in Azerbaijan to contribute to Nabucco project, http://www.today.az/news/business/63628.html

Rzayeva, Bulgaria obtained a $22 \%$ discount, Romania 5\%, Hungary $2 \%$ and Austria $11 \%$ in The Southern Gas Corridor: Who Stands Where? http://www.naturalgaseurope.com/southern-gascorridor-gulmira-rzayeva

SOCAR Takes Over Shah Deniz Gas Sales, Natural Gas Europe, http://www.naturalgaseurope.com/socar-shah-deniz-gas-sales-23502

SOCAR announces tender for the joint development of gas fields in the Caspian Sea, http://www.contact.az/docs/2014/Economics\&Finance/091000089970en.htm\#.VBwSYxZ8qM4

South Caucasus Pipeline Expansion Contract Awarded,http://www.offshoreenergytoday.com/southcaucasus-pipeline-expansion-contract-awarded/

Statoil exits Shah Deniz gas project with stake sale to Petronas, Reuters, http://www.reuters.com/article/2014/10/13/us-statoil-petronas-shahdenizidUSKCN0I209020141013 The New Agreement between BP Azerbaijan and South Caucasus Pipeline, http://www.contact.az/docs/2013/Economics\&Finance/012300025666en.htm\#.VB V BZ8aM4 Total Sells $\$ 1.5$ Billion Azeri Gas-Project Stake to Turkey, Bloomberg, http://www.bloomberg.com/news/2014-05-29/turkey-to-increase-stake-in-azerbaijan-s-shah-denizgas-project.html 

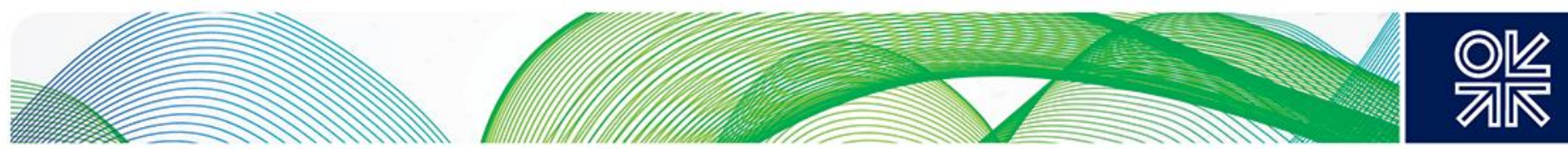

Total to sell its stake in Azeri Shah Deniz gas field, Reuters, http://uk.reuters.com/article/2014/02/28/gas-azerbaiian-total-idUKL6N0LX2U820140228

Total Investment in Shah Deniz Gas Field at \$11.4 Billion, http://www.naturalgaseurope.com/shahdeniz-gas-field-investments-profit

Total to sell its stake in Azeri Shah Deniz gas field, Reuters, http://uk.reuters.com/article/2014/02/28/gas-azerbaijan-total-idUKL6N0LX2U820140228

Turkey expects $\$ 27.8$ bln gross in Shah Deniz project, Daily Sabah,

http://www.dailysabah.com/energy/2014/06/02/turkey-expects-278-bln-gross-in-shah-deniz-project Türkiye Büyük Millet Meclisi, Yasama Dönemi 24, Yasama Yılı 4, Sıra Sayısı 646, Türkiye Cumhuriyeti Hükümeti ile Azerbaycan Cumhuriyeti Hükümeti Arasında Trans Anadolu Doğal Gaz Boru Hattı Sistemine İlişkin Hükümetlerarası Anlaşmanın Eki Türkiye Cumhuriyeti Hükümeti ve The Trans Anatolian Gas Pipeline Company B. V. Arasında Trans-Anadolu Doğal Gaz Boru Hattı Sistemi Hakkında Ev Sahibi Hükümet Anlaşmasına Ilişkin Değişikliğin Onaylanmasının Uygun Bulunduğuna Dair Kanun Tasarısı ve Dışişleri Komisyonu Raporu (1/947), http://www.tbmm.gov.tr/sirasayi/donem24/yil01/ss642.pdf World Energy Outlook 2014 